\title{
DR- $1007-3$
}

UTILITIES AND OFFSITES DESIGN BASELINE

\section{MSIG}

May 25, 1984

Date Revised

Work Performed Under Contract No. AC05-780R03054

The Rust Engineering Company

Birmingham, Alabama

Technical Information Center Office of Scientific and Technical Information United States Department of Energy 


\section{DISCLAIMER}

This report was prepared as an account of work sponsored by an agency of the United States Government. Neither the United States Government nor any agency Thereof, nor any of their employees, makes any warranty, express or implied, or assumes any legal liability or responsibility for the accuracy, completeness, or usefulness of any information, apparatus, product, or process disclosed, or represents that its use would not infringe privately owned rights. Reference herein to any specific commercial product, process, or service by trade name, trademark, manufacturer, or otherwise does not necessarily constitute or imply its endorsement, recommendation, or favoring by the United States Government or any agency thereof. The views and opinions of authors expressed herein do not necessarily state or reflect those of the United States Government or any agency thereof. 


\section{DISCLAIMER}

Portions of this document may be illegible in electronic image products. Images are produced from the best available original document. 


\section{DISCLAIMER}

This report was prepared as an account of work sponsored by an agency of the United States Government. Neither the United States Government nor any agency thereof, nor any of their employees, makes any warranty, express or implied, or assumes any legal liability or responsibility for the accuracy, completeness, or usefulness of any information, apparatus, product, or process disclosed, or represents that its use would not infringe privately owned rights. Reference herein to any specific commercial product, process, or service by trade name, trademark, manufacturer, or otherwise does not necessarily constitute or imply its endorsement, recommendation, or favoring by the United States Government or any agency thereof. The views and opinions of authors expressed herein do not necessarily state or reflect those of the United States Government or any agency thereof.

This report has been reproduced directly from the best available copy.

Available from the National Technical Information Service, U. S. Department of Commerce, Springfield, Virginia 22161.

Price: Printed Copy A10

Microfiche A01

Codes are used for pricing all publications. The code is determined by the number of pages in the publication. Information pertaining to the pricing codes can be found in the current issues of the following publications, which are generally available in most libraries: Energy Research Abstracts (ERA); Government Reports Announcements and Index (GRA and I); Scientific and Technical Abstract Reports (STAR); and publication NTIS-PR-360 available from NTIS at the above address. 


\section{International Coal Refining Company}

\section{UTILITIES AND OFFSITES DESIGN BASELINE}

\section{OUTSIDE BATTERY LIMITS FACILITY 6000 TPD SRC-I DEMONSTRATION PLANT}

FOR

\section{U.S. DEPARTMENT OF ENERGY}

VOLUME II

Prepared By

The Rust Engineering Company

Blrmingham. Alabama

REVISED MAY 25, 1984 
TABLE OF CONTENTS

VOLUME I

Section

Page

1.0 INTRODUCTION

1.1

1.1 SUMMARY - 1.1

1.2 TECHNICAL SCOPE -

1.3 DESIGN BASIS MEMORANDUM -

1.4 STANDARD DRAWING SYMBOLS - 1.6

2.0 UTILITY SYSTEMS - 2.0

2.1. ELECTRICAL POWER DISTRIBUTION

2.1.1 $161 \mathrm{kV}$ Incoming Power $2.1-2$

2.1.1.1 System Description - 2.1-2

2.1.1.2 Single Line D1agram -

2.1.1.3. Layout Draw1ng -

2.1.1.4 Equipment L1st/Summary -

2.1.2 Main Substation

2.1.2.1 System Description -

2.1.2.2 Single Line Diagrams - -

2.1.2.3 Layout Drawings _- 2.1-6

2.1.2.4 Equipment List/Summary - 2.1-7

2.1.3 13.8 KV Distribution System 2.1-8

2.1.3.1 System Description - $2.1-8$

2.1.3.2 Single Line Diagrams -

2.1.3.3 Equipment List/Summary _. $2.1-10$

2.1.4 Electrical Interconnecting Systems - 2.1-11

2.1.4.1 System Description - 2.1-11

2.1.4.2 Single Line Diagrams -

2.1.5 Emergency Power

2.1.5.1 System Description - 2.1-13

2.1.5.2 Process Flow Dlagram

2.1.5.3 Single Line Diagram -

2.1.5.4 Equipment L18t Summary

2.1.5.5 Equipment Data Sheets - 2.1-17 


\section{TABLE OF CONTENTS}

VOLUME I

(Continued)

\subsubsection{L1ghting}

2.1-18

2.1.6.1 System Description

2. 1-18

2.1.6.2 Electrical Drawings

2.2 PLANT UTILITIES

$2.2-1$

2.2.1 Fire Protection

$2.2-2$

2.2.1.1 System Description

2.2-2

2.2.1.2 Ut1lity Flow Dlagrams

2. $2-7$

2.2 .1 .3

Equipment L1st Summary

2. 2-8

2.2 .1 .4

Equipment Data Sheets

2. 2-9

2.2.2 Boller Feedwater Treatment System

$2.2-10$

2.2.2.1

2.2.2.2

2.2 .2 .3

2.2 .2 .4

2.2 .2 .5

2.2.2.6
System Description

vellity Flow Diagrams

Ut1lity Summary

Motor List

Equipment List/Summary

Equipment Data Sheets
2. 2-10

2. 2-12

2. 2-12A

2. 2-12B

2. $2-13$

2. $2-14$

$2.2-15$

2. 2-15

2. 2-18

2. $2-18 \mathrm{~A}$

2. 2-18B

2. $2-18 \mathrm{C}$

2. $2-19$

2. $2-20$

2. 2-21

2.2.3.7

2.2 .3 .8

Layout Drawings

Equipment List/Summary

Equipment Data Sheets

\section{VOLUME II}

\subsubsection{Cooling Water System}

$2.2-22$

2.2.4.1 System Description

2. 2-22

2.2.4.2

Utiltty Flow Dlagrams

2. 2-24

2. 2.4 .3

Utility Summary

2. $2-24 \mathrm{~A}$

2.2 .4 .4

Motor List

2.2.4.5

Equipment L1st/Summary

2. 2-24B

2.2 .4 .6

Equipment Dataj Sheets

2. 2-25

2. $2-26$ 
TABLE OF CONTENTS

VOLUME II

(Continued)

2.2.5 Process Water Supply

2.2.5.1 System Description

2.2.5.2 Ut111ty Flow Diagrams - 2.2-27

2.2.6 Putable Hater Supply 2.28

2.2.6.1 System Description - 2.2-28

2.2.6.2 Utility Flow Dlagram

2.2 .7 Nitrogen System $2.2-29$

2.2.7.1 System Descriptioñ - 2.2-29

2.2.7.2 Ut1l1ty Flow Diagrams

2.2.8 Compressed Afr System 2.2-30

2.2.8.1 System Description - 2.2-30

2.2.8.2 Ut1l1ty Flow Diagram - 2.2-31

2.2.8.3 Ut1I1ty Summary _- 2. $31 \mathrm{~A}$

2.2.8.4 Motor L1st _- 2.2-31B

2.2.8.5 Equipment List/Summary - 2.2-32

2.2.8.6 Equipment Data Sheets - 2.2-33

2.2.9 Flare and Incinerators

2.2.9.1 System Description - $2.2-34$

2.2.9.2 Ut1l1ty Flow Diagrams - 2.2-40

2.2.9.3 Materlal and Energy Balances -

2.2.9.4 Util1ty Sumnary - 2.2-40B

2.2.9.5 Motor List - 2.2-40C

2.2.9.6 Equipment List/Summary _- 2. 2-41

2.2.9.7 Equipment Data Sheets - 2.2-42

2.2.10 Fuels

2.2.10.1 System Description - 2.2-43

2.2.10.2 Ut111ty Flow Diagrams - 


\section{TABLE OF CONTENTS}

\section{VOLUME II}

(Continued)

2.3 INTERCONNECTING SYSTEMS - 2.3-1

2.3.1 Factlities Description -

2.3. IA ICRC Interface Integration

2.3.2 Interconnecting Diagrams _. 2.3-3

2.3.3 Layout Drawings _- 2.3-4

2.4 UTILITY SYSTEMS INTEGRATION

2.4.1 Instrumentat1on Requirements

\section{VOLUME III}

3.0 OFFSITES - 0.1

3.1 WATER AND WASTE TREATMENT

3.1.1 Potable Water Treatment

3.1.1.1 Process Description -

3.1.1.2 Process Flow Diagrams -

3.1.1.3 Ut111ty Summary _- $3.1-3 \mathrm{~A}$

3.1.1.4 Motor L1st _- 3.1-3B

3.1.1.5 Layout Drawing _- $3.1-4$

3.1.1.6. Equipment List/Summary - 3.1-5

3.1.1.7 Equipment Data Sheets

3.1 .2 Process Water Treatment

3.1.2.1 Procesg Description - 3.1-7

3.1.2.2 Process Flow Dlagrams

3.1.2.3 Ut1lity Summary -

3.1.2.4 Motor L1st -

3.1.2.5 Layout Drawing _-_ 3.1-10

3.1.2.6 Equipment List/Summary - 3.1-11

3.1.2.7 Equipment Data Sheets - 3.1-12

3.1.3 Wastewacer Treacment - 3.1-13

3.1.3.1 Process Description - 3.1-13

3.1.3.2 Process Flow Dlagrams

3.1.3.3 Materlal Balance - 
TABLE OF CONTENTS

VOLUNE III

(Continued)

Section

3.1.3.4 Ut1lit1es Summary -

3.1.3.5 Motor List - 3.1-26C

3.1.3.6 Layout Drawing _- 3.1-27

3.1.3.7 Equipment List/Summary _- 3.1-28

3.1.3.8 Equipment Data Sheets - 3.1-29

3.1.4 Waste Sol1ds Handling - 3.1-30

3.1.4.1 Process Description -

3.1.4.2 Process Flow Dlagram and Sketches -

3.1.4.3 Ut111ty Summary

3.1.4.4 Motor L1st

3.1.4.5 Layout Utawing _- 3.1-34

3.1.4.6 Equipment L18t/Summary _- 3.1-35

3.1.4.7 Equipment Data Sheets

VOLUME IV

\subsection{SITE DEVELOPMENT}

3.2.1 Raflroads - 3.2-1

3.2.1.1 Facilities Description -

3.2.1.2 Layout Drawing - 3.2-3

3.2.2 Fencing, Roadways, and Parking

3.2.2.1 Fac1lit1es Description -

3.2.2.2 Layout Drawings - 3.2-5A

3.2.3 Site Preparation -

3.2.3.1 Facilit1es Description -

3.2.3.2 Site Plan and Related Drawings

3.2.4 River Structures

3.2.4.1 Fac111ties Description - 3.2-8

3.2.4.2 Layout Drawings

3.2.5 Final Grading and Landscaping - 3.2-9

3.2.5.1 Facilities Description -

3.2.5.3 . Plot Plan 3.2-9 


\section{TABLE OF CONTENTS}

VOLUME IV

(Continued)

Section

Page

3.3 BUILDINGS - 3.3

3.3.1 General Description - 3.3-2

3.3.2 Central Control Bullding

3.3.2.1 Fac1lities Description -

3.3.2.2 Layout Drawings _- 3.3-4

3.3.2.3 Equipment List/Summary

3.3.3 Admintstration Building 3.3-6

3.3.3.1 Fac1lities Description - 3.3-6

3.3.3.2 Layout Drawings _-_ 3.3-7

3.3.3.3 Equ1pment L1st/Summary _- 3.3-8

3.3.4 Service Change Building - 3.3-9

3.3.4.1. Fac1lities Description -

3.3.4.2 Layout Drawings - 3.3-9

3.3.4.3 Equipment List/Summary _... 3.10

3.3.5 Contract Malntenance Service Change Bullding - -- 3.3-11

3.3.5.1 Fac1lities Description -

3.3.5.2 Layout Drawings _- 3.3-11

3.3.5.3 Equipment List/Sumary _- 3.3-12

3.3.6 Warehouse and Storage Buflding

3.3.6.1 Fac1lities Description -

3.3.6.2 Layout Drawings _- 3.3-13

3.3.6.3 Equipment List/Summary —... 3.3-14

3.3.7 Malntenance Bullding - 3.3-15

3.3.7.1 Factlities Descrlption -

3.3.7.2 Layout Drawings 3.3-16

3.3.8 Operators Shelters 3.j-17

3.3.8.1 Fac1lities Description - 3.3-18 


\section{TABLE OF CONTENTS}

VOLUME IV

(Continued)

Section

Page

3. 3.9 Sw1tchgear Building

3.3.9.1 Facilities Description - 3.3-18

3.3.9.2 Layout Drawings

3.3.10 Motor Control Center Bulldings 3.3-19

3.3.10.1 Fac1lities Description - 3.3-19

3.3.10.2 Layout Drawings - 3.3-1y

3.3.11 Heating, Ventilating, and Afr Conditioning (HVAC)- 3.3-20

3.3.11.1 Facilities Description $\cdots 3.20$

4.0 RAW MATERIALS AND PRODUCT HANDLING AND STORAGE -

4.1 LIQUID STORAGE - 4.1-1

4.1.1 Fac1lities Description - 4.1-1

4.1.2 Process Flow Dlagrams - 4.1-5

4.1.3 Ut1lity Sumary $4.1-5 \mathrm{~A}$

4.1.4. Motor List

4.1.5 Layout Drawings _- 4.1-6

4.1.6 Equipment List/Summary

4.1.7 Equipment Data Sheets 4.1-8

4.2 COAL STORAGE AND TRANSFER- 4.2-1

4.2.1 Facilities Description - 4.2-1

4.2.2 Process Flow Dlagrams - 4.2-9

4.2.3. Utility Sumary $4.2-9 \mathrm{~A}$

4.2.4 Motor List - 4.2-9B

4.2.5 Layout Drawings _- 4.2-10

4.2.6 Equipment List/Summary - 4.2-11

4.2.7 Equipment Data Sheets 
TABLE OF CONTENTS

VOLUME IV

(Continued)

Section

$\underline{\text { Page }}$

4. 3 COAL PULVERIZING

4.3-1

4.3.1 Facilities Description - 4.3-1

4.3.2 Process Flow Dlagram

4.3.3 Utility Sumary $4.3-4 \mathrm{~A}$

4.3.4 Motor L1st

4.3.5 Layout Drawings _- 4.3-5

4.3.6 Equipment List/Summary - 4.3-6

4.3.7 Equipment Data Sheets

4.4 SRC HANDLING AND STORAGE

4.4.1 Pacilities Description - 4.4-1

4.4.2 Process Flow Dlagrams

4.4.3 Ut1lity Summary $4.4-5 \mathrm{~A}$

4.4.4 Motor List

4.4.5 Layout Draw1ngs

4.4.6 Equipment List/Summary - 4.4-7

4.4.7 Equipment Data Sheets

VOLUME $\mathbf{V}$

Wastewater Treatment System and Sol1d Wastes Landfili for 6,000 TPD SRC-I Demonstration Plant (DOE/OR/03054-71)

\section{VOLUME VI}

3.1.3 Wastewater Treatment (Conf1dential Version) -..-- 3.1-13

3.1.3.1 Process Description - 3.1-13

3.1.3.2 Process Flow Dlagram _- 3.1-26

3.1.3.3 Mater1al Balance -

3.1.3.4 Ue111ty Summary -

3.1.3.5 Motor L1st -

3.1.3.6 Layout Drawing -

3.1.3.7 Equipment List/Summary _._. 3.1-28

3.1.3.8 Equipment Data Sheets $\ldots$ 


\subsubsection{Cooling Water System}

2.2.4.1 System Description (Refer to Process Flow Diagrams No. 00-16-01014D and $00-16-01015 \mathrm{D})$

\subsection{General}

The cooling water system includes two cooling tower systems, cooling tower No. 1 and cooling tower No. 2. Each cooling tower system consists of a distribution header, a collection header, the cooling tower, and cooling tower associated equipment.

\subsection{Cooling Tower No. 1}

2.2.4.1.2.1 The cooling tower (CT-16601) will be cross-flow design. The hot water enters the distribution basin in the top of the tower and falls by gravity through the cooling tower fill into a cold water basin. The cooling water supply pumps ( $P-16603 \mathrm{~A}$ through $F$ ) are located in a sump at the end of the cold water basin. Removable screens are provided to prevent large solids from entering the pump suctions. The vertical turbine cooling water supply pumps will maintain a constant pressure on the distribution header. The cooling tower fans $(C-16601 \mathrm{~A}-\mathrm{K})$ can be started or shutdown to provide the proper water temperature for the distribution system header. The cooling water from all areas together with the blowdowns from bollers will be oollected in a central header and returned to the cooling tower.

2.2.4.1.2:2 A cooling tower chlorinator $(X-16603)$ is provided to prevent microbiological growth in the tower or. in the cooling water system. An inhtbitor feed system (X-16601) w11l meter inhibitor into the coolng water system to provide corrosion control. The cooling tower blowdown stream will flow to the wastewater treatment area through interconnecting piping systems. A sulfuric acid feed system (X-16602) will meter acid into the 
cooling water system to maintain the proper $\mathrm{pH}$ level. Makeup water to the cooling tower will be supplied from the process water distribution system to maintain level in the cold water basin. Other makeup water sources Include evaporator condensate, treated wastewater and boiler blowdowns.

\subsection{Cooling Tower No. 2}

2.2.4.1.3.1 The cooling tower ( $C T-16610)$ will be cross-flow design. The hot water enters the distribution basin in the top of the tower and

- falls by gravity through the cooling tower fill into a cold water baein. The cooling water supply pumps (P-16612 A-E) are located in a sump at the end of the cold water basin. Removable screens are provided to prevent large solids from entering the pump suctions. The vertical turbine cooling water supply pumps will maintain a constant pressure on the distribution header. The cooling tower fans (C-16610 A-C ) can be started or shutdown to provide the proper water temperature for the distribution system header. The cooling water from all areas will be collected in a central header and returned to the cooling tower.

2:2.4.1.3.2 A cooling tower chlorinator $(X-16612)$ is provided to prevent microbiological growth in the tower or in the cooling water system. An inhibitor feed system $(X-16610)$ will meter Inhibitor into the cooling water system to provide corrosion control. The cooling tower blowdown stream will flow to the wastewater treatment area. A sulfuric actd feed system $(X-16611)$ will meter acid into the cooling water system to maintain the proper $\mathrm{pH}$ level. Makeup water to the cooling tower will be supplied from the process water distribution system to maintain level in the cold water basin. 


\subsubsection{Utility Flow Diagrams}

The following utility flow diagrams are included after this page:

$$
\begin{gathered}
\text { 00-16-01014D Cooling Water System Process and Control } \\
\text { Diagram (Sheet 1) } \\
\text { 00-16-01015D Cooling Water System Process and Control } \\
\text { Diagram (Sheet } 2 \text { ) }
\end{gathered}
$$




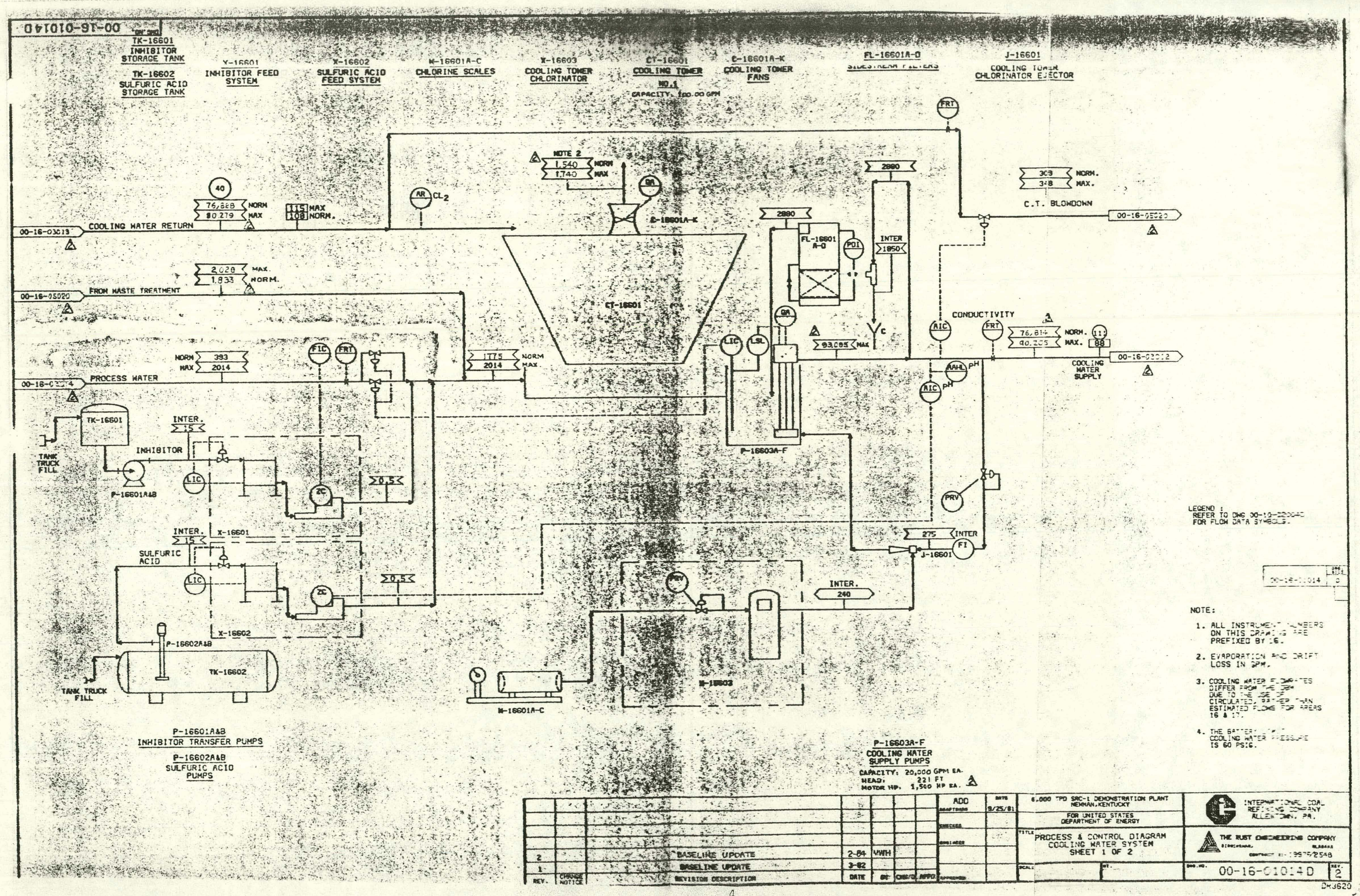




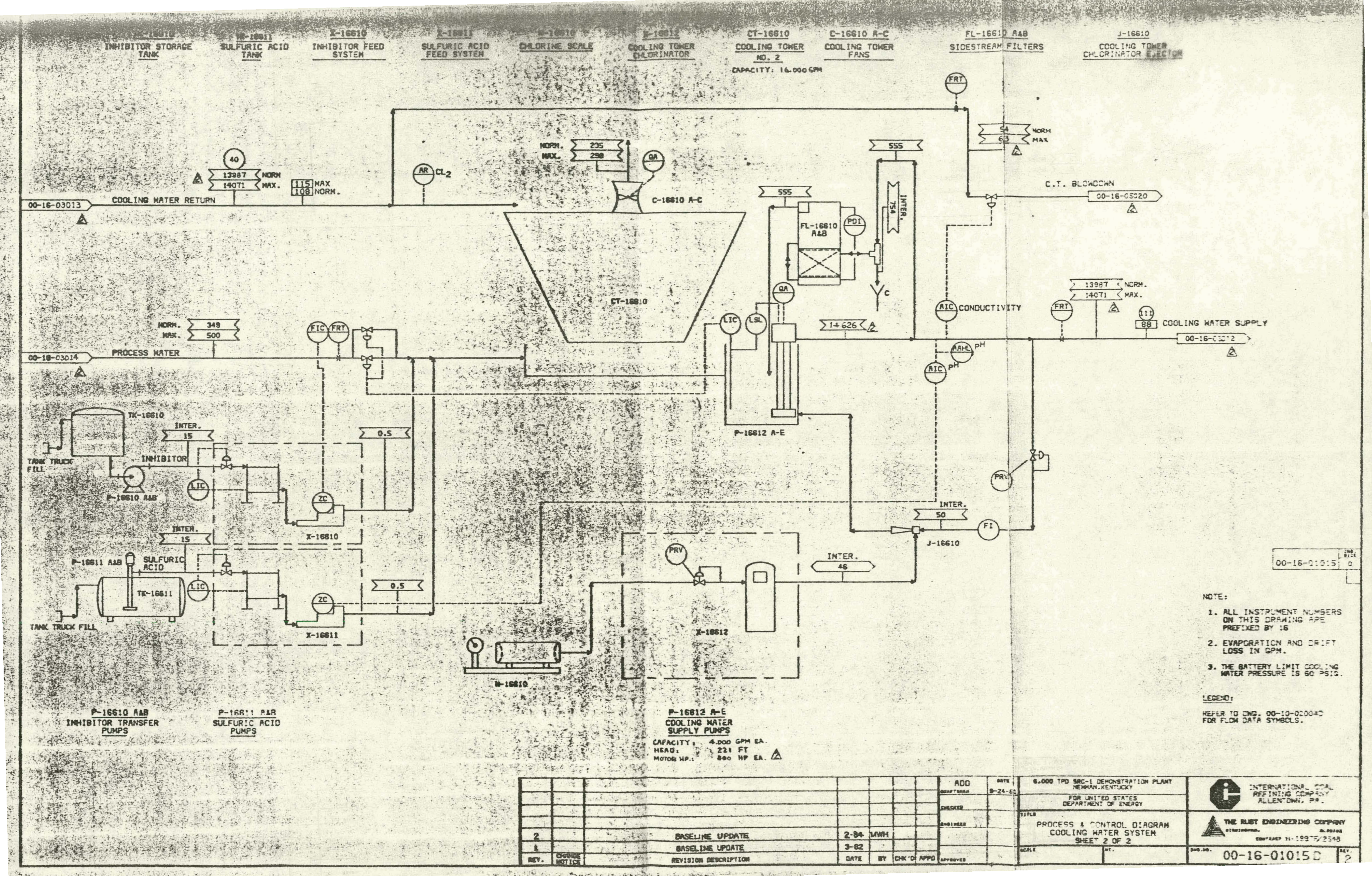




\subsubsection{Utility Summary}

The utility summary for the cooling water system follows this page. 


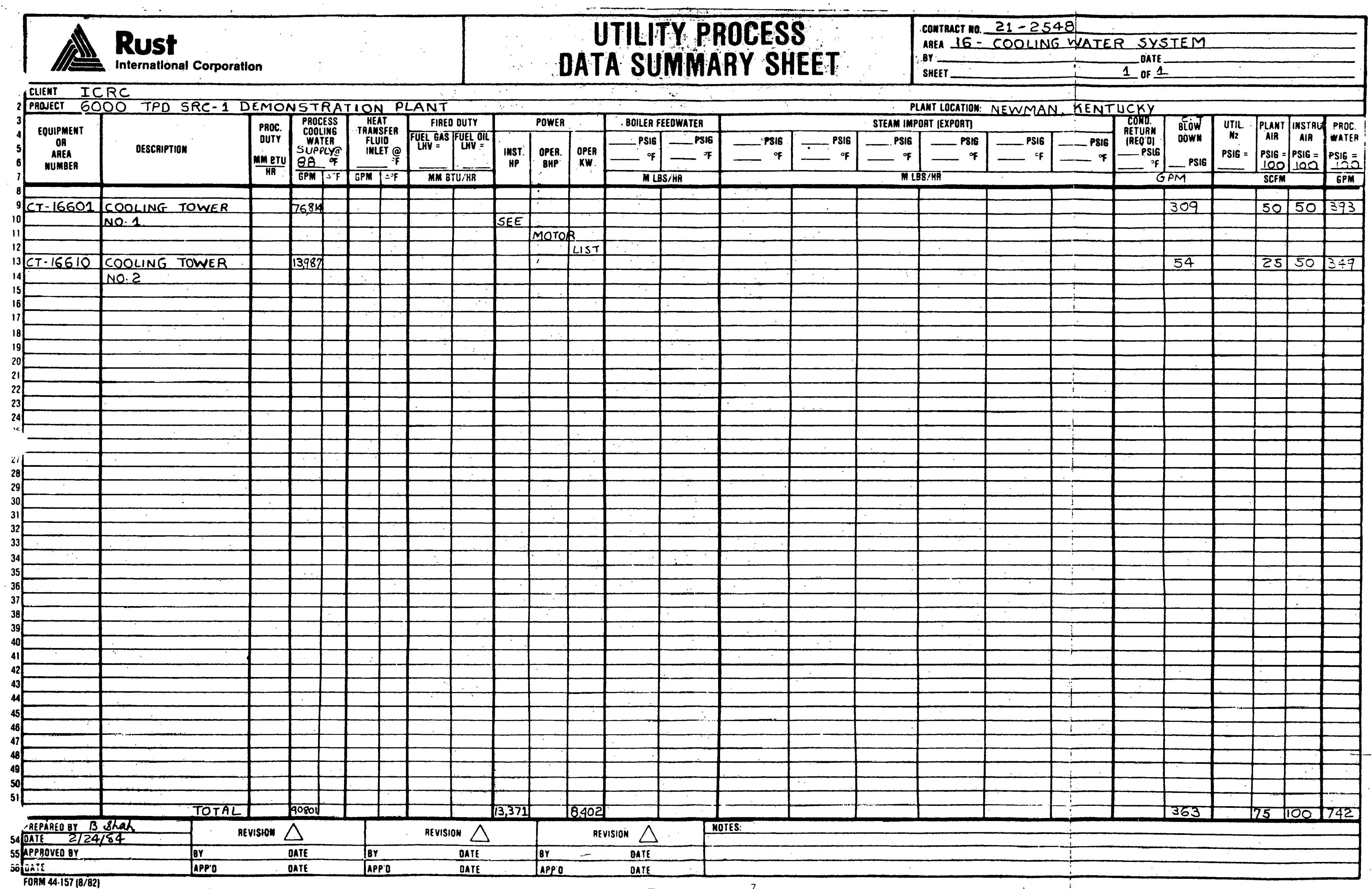




\subsubsection{Motor List}

The motor list for the cooling water system follows this page. 
COOLING WATER SYSTEM

MOTOR LIST

Equipment

No.

C-16601A Cooling Tower Fan

C-16601B Cooling Tower Fan

C-16601C Cooling Tower Fan

C-16601D Cooling Tower Fan

C-16601E Cooling Tower Fan

C-16601F Cooling Tower Fan

C-16601G Cooling Tower Fan

C-16601H Cooling Tower Fan

C-16601I Cooling Tower Fan

C-16601J Cooling Tower Fan

C-16601K Cooling Tower Fan

C-16610A Cooling Tower Fan

C-16610B Cooling Tower Fan

C-16610C Cooling Tower Fan

P-16601A Corrosion Inhibitor Pump

P-16601B Corrosion Inhibitor Pump

P-16602A Sulfuric Acid Pump

P-16602B Sulfuric Acid Pump

P-16603A Cooling Water Supply Pump

P-16603B Cooling Water Supply Pump

P-16603C Cooling Water Supply Pump

P-16603D C Cooling Water Supply Pump

P-16603E Cooling Water Supply Pump

P-16603F Cooling Water Supply Pump

P-16610^ Corrosion Inhibitor Pump

P-16610B Corrosion Inhibitor Pump

P-16611A Sulfuric Acid Pump

P-16611B Sulfuric Ac1d Pump
Installed Operating Hours/ KWH/

Hp

250

250

250

250

250

250

250

250

250

250

250

125

125

125

1

1

1

1

1,500

1,500

1,500

1,500

1,500

1,500

1

1

1

1
KW Day Day

150

150

150

150

150

150

150

150

150

150

105

90

90

90

0.3

0

0.3

0

1,120

1,120

1,120

1,120

1,120

0

0.3

0

0.3

0
243,600

243,600

243,600

243,600

243,600

$24 \quad 3,600$

$24 \quad 3,600$

$24 \quad 3,600$

243,600

243,600

243,600

24. 2,160

242,160

$24 \quad 2,160$

24

7

0

24

0

7

b

$24 \quad 26,880$

$24 \quad 26,880$

$24 \quad 26,880$

- $24 \quad 26,880$

$24 \quad 26,880$

0

24

0

24

0 
Cooling Water System

Motor List

(Continued)

Equipment

No.

P-16612A Cooling Water Supply Pump.

P-15612B Cooling Water Supply Pump

P-16612C Cooling Water Supply Pump

P-16612D Cooling Water Supp1y Pump

P-16612E Cooling Water Supply Pump

$\mathrm{X}-16601 \mathrm{~A}$ Chemical Feed Pump

$X-16601 B$ Chemical Feed Pump

$X-16602 \mathrm{~A}$ Chemical Feed Pump

$X-16602 B$ Chemical Feed Pump

X-16610A Chemical Feed Pump

$X-16610 B$ Chemical Feed Pump

$X-16611 A$ Chemical Feed Pump

$X-16611 B$ Chemlcal Feed Pump

\begin{tabular}{|c|c|c|c|}
\hline $\begin{array}{c}\text { Installed } \\
\mathrm{Hp}\end{array}$ & $\begin{array}{c}\text { Operating } \\
\mathrm{KW}\end{array}$ & $\begin{array}{l}\text { Hours/ } \\
\text { Day }\end{array}$ & $\begin{array}{l}\text { KWH/ } \\
\text { Day }\end{array}$ \\
\hline 300 & 220 & 24 & 5,280 \\
\hline 300 & 220 & 24 & 5,280 \\
\hline 300 & 220 & 24 & 5,280 \\
\hline 300 & 200 & 24 & 5,280 \\
\hline 300 & 0 & 0 & 0 \\
\hline 1 & 0.1 & 24 & 2 \\
\hline 1 & 0 & 0 & 0 \\
\hline 1 & 0.1 & 24 & 2 \\
\hline 1 & 0 & 0 & 0 \\
\hline 1 & 0.1 & 24 & 2 \\
\hline 1 & 0 & 0 & 0 \\
\hline 1 & 0.1 & 24 & 2 \\
\hline 1 & 0 & 0 & 0 \\
\hline
\end{tabular}

13,371

8,402

201,636 
2.2.4.5 Equipment List/Summary

The equipment list/summary for the cooling water system follows this page. 
EQUIPAEIT LIST/SWRARY REV. E 02-06-84

WBS ELEAENT: 1.4.1.1.2 - ICRC AREA: 16

COOLIMG MATER--COOLING TOWER 1

PAGE 1 OF 3

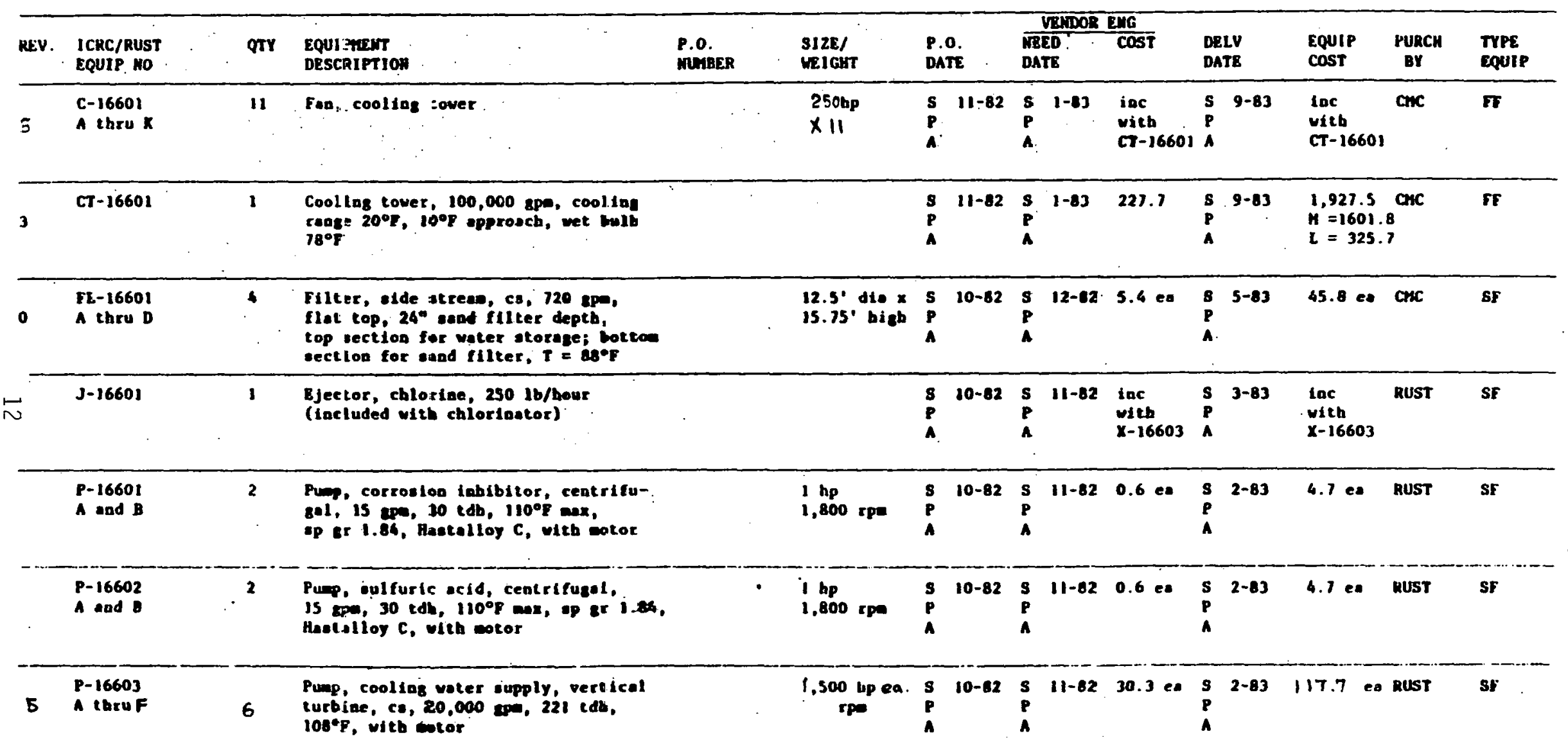

\section{BOTES:}

1. All coste lat querter Fitucal Year 1982 is tbousand dollers.

2. Equipered costs ore pos jobstie with shippins 6 vendor field

nusT: Rust Engíneerios suppore less verdor englineering.
3. Tis equipment is appendia $C$ Bulls.
S: Scheduled
P: Projerted

P: Projereed
PL: Field Labor M/A: Mol Applicable H: Hoteriol for field fab equipent SF: Shop Fabricated FF: Field Fabricated 
EQUIPHENT LIST/SUPPAARY REV. 4 03-26-82 COOLING WATER--COOLING TOWER I

PAGE 2 OF 3

\begin{tabular}{|c|c|c|c|c|c|c|c|c|c|c|c|c|c|c|c|}
\hline \multirow{3}{*}{ REV: } & \multirow{3}{*}{$\begin{array}{l}\text { ICRC/RUST } \\
\text { EQUIP NO } \\
\text { TK-16601 }\end{array}$} & \multirow{3}{*}{ QTY } & \multirow{3}{*}{$\begin{array}{l}\text { EQUI PRENT } \\
\text { DESCRIPTION } \\
\text { Tank, inhibitor storsge, fiberglass, } \\
1,000 \text { gal capacity, covered, flat top, } \\
0_{\text {psiB, } 90^{\circ} \mathrm{F} \text { max }}\end{array}$} & \multirow{3}{*}{\multicolumn{2}{|c|}{$\begin{array}{l}\text { P.o. } \\
\text { MUMBER } \\
\end{array}$}} & \multirow{3}{*}{$\begin{array}{l}\text { SIZE/ } \\
\text { WEIGHT } \\
6 \cdot \text { dia } \\
4.5 \text { high }\end{array}$} & \multirow{2}{*}{\multicolumn{2}{|c|}{$\begin{array}{l}\text { P.o. } \\
\text { DATE }\end{array}$}} & \multicolumn{3}{|c|}{ VENDOR ENG } & \multirow[b]{2}{*}{$\begin{array}{l}\text { DELV } \\
\text { DATE }\end{array}$} & \multirow{3}{*}{$\begin{array}{l}\text { EQUIF } \\
\operatorname{cosT} \\
3.1\end{array}$} & \multirow{3}{*}{ 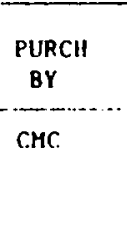 } & \multirow{3}{*}{$\begin{array}{l}\text { TYPE } \\
\text { EQUIP } \\
\text { SF }\end{array}$} \\
\hline & & & & & & & & & $\begin{array}{l}\overline{\text { NEE }} \\
\text { DAT }\end{array}$ & $\begin{array}{l}\text { ED } \\
\text { TE }\end{array}$ & $\cos \mathrm{T}$ & & & & \\
\hline & & & & & & & $\begin{array}{l}\mathbf{S} \\
\mathbf{P} \\
\mathbf{A}\end{array}$ & $10-82$ & $\begin{array}{l}\mathbf{S} \\
\mathrm{P} \\
\mathrm{A}\end{array}$ & $12-82$ & 0.4 & $\begin{array}{ll}\text { S } & 4-83 \\
\text { P } & \\
\text { A } & \end{array}$ & & & \\
\hline & TK- 16602 & 1 & $\begin{array}{l}\text { Tank, sulfuric ocid, cs, } 10,000 \mathrm{gal} \\
\text { capacity, horizootal, } 0 \text { p8ig, } 110^{\circ} \mathrm{F} \\
\text { max. }\end{array}$ & . & & $\begin{array}{l}12^{\circ} \text { dis } x \\
12^{\circ} \text { IT }\end{array}$ & $\begin{array}{l}\mathbf{S} \\
\mathbf{P} \\
\mathbf{A}\end{array}$ & $10-82$ & $\begin{array}{l}\mathbf{S} \\
\mathbf{P} \\
\mathbf{A}\end{array}$ & $12-82$ & 1.6 & $\begin{array}{ll}S & 4-83 \\
\text { P } & \\
\text { A } & \end{array}$ & 13.4 & CMC & SF \\
\hline & $\begin{array}{l}\text { W-16601 } \\
\text { A thru C }\end{array}$ & 3 & $\begin{array}{l}\text { Scsle, chloride, con cyllader, } \\
3,600 \text { ib load, tank ize } 6.67 ! \times \\
2.5^{\circ} \text { diameter }\end{array}$ & & & & $\begin{array}{l}\text { S } \\
\mathbf{P} \\
\mathbf{A}\end{array}$ & 10-82 & $\begin{array}{l}\mathbf{S} \\
\mathbf{P} \\
\mathbf{A}\end{array}$ & $11-82$ & $0.7 \mathrm{ea}$ & $\begin{array}{ll}S & 3-83 \\
\text { P } & \\
\text { A } & \end{array}$ & $6.0 \mathrm{ea}$ & RUST & SF \\
\hline & $x-16601$ & 1 & $\begin{array}{l}\text { Chemical feed syoted, inhibitor, } \\
\text { Inc vertical tank, } 316 \mathrm{SS}, 100 \mathrm{gal} \\
\text { capacity, open top }\end{array}$ & & & $\begin{array}{l}2.58^{\prime} \text { dia } x \\
3.1^{\circ} \text { bigh }\end{array}$ & $\begin{array}{l}S \\
P \\
A\end{array}$ & $10-82$ & $\begin{array}{l}\mathbf{S} \\
\mathbf{P} \\
\mathbf{A}\end{array}$ & $12-82$ & 0.8 & $\begin{array}{ll}S & 4-83 \\
\text { P } & \\
\text { A } & \end{array}$ & 7.0 & RUST & SF \\
\hline 4 & $\begin{array}{l}x-16601 \\
\text { con't }\end{array}$ & 2 & $\begin{array}{l}\text { Pump, } 316 \text { SS, diaphraga, } 0.5 \mathrm{gpm} \\
100 \text { tdh, abbient teap., sp } \mathrm{gr} \text { I.I, } \\
\text { with notor }\end{array}$ & & & $\begin{array}{l}1 \mathrm{hp} \\
1,800 \mathrm{rpw}\end{array}$ & $\begin{array}{l}S \\
P \\
A\end{array}$ & $10-82$ & $\begin{array}{l}\mathbf{S} \\
\mathbf{P} \\
\mathbf{A}\end{array}$ & $12-82$ & $\begin{array}{l}\text { inc } \\
\text { with } \\
x-16601\end{array}$ & $\begin{array}{ll}\text { S } & 4-83 \\
\text { P } & \\
\text { A } & \end{array}$ & $\begin{array}{l}\text { inc } \\
\text { with } \\
x-16601\end{array}$ & RUST & SF \\
\hline . & $x-16602$ & 1 & $\begin{array}{l}\text { Chemical feed aystee, sulforic acid, } \\
\text { inc vertical tank, } 3: 6 \mathrm{SS}, 100 \mathrm{gal} \\
\text { capacity, open top }\end{array}$ & & . & $\begin{array}{l}2.5 B^{\prime} \text { dia } x \\
3.1 \text { high }\end{array}$ & $\begin{array}{l}\mathbf{S} \\
\mathbf{P} \\
\mathbf{A}\end{array}$ & $10-82$ & $\begin{array}{l}\mathbf{S} \\
\mathbf{P} \\
\mathbf{A}\end{array}$ & $12-82$ & 0.6 & $\begin{array}{ll}S & 4-B 3 \\
P & \\
A & \end{array}$ & 4.5 & RUST & SF \\
\hline 4 & $\begin{array}{l}x-16602 \\
\text { con't. }\end{array}$ & 2 & $\begin{array}{l}\text { Pump, } 316 \text { SS, diaphrogm, } 0.5 \text { spe, } \\
100 \text { idh, anbieat teap, sp gr } 1.84 \text {, } \\
\text { with ootor }\end{array}$ & & & $\begin{array}{l}1 \mathrm{hp} \\
1,800 \mathrm{rpm}\end{array}$ & $\begin{array}{l}S \\
P \\
A\end{array}$ & $10-82$ & $\begin{array}{l}\mathbf{S} \\
\mathbf{P} \\
\mathbf{A}\end{array}$ & 12-82 & $\begin{array}{l}\text { inc } \\
\text { with } \\
x-16602\end{array}$ & $\begin{array}{ll}\text { S } & 4-83 \\
\text { P } & \\
\text { A } & \end{array}$ & $\begin{array}{l}\text { inc } \\
\text { with } \\
x-16602\end{array}$ & RUST & $\mathbf{S F}$ \\
\hline $\begin{array}{l}\text { MOTES } \\
\text { 1. AI } \\
\text { 2. Eq }\end{array}$ & $\begin{array}{l}\text { costs lst } \\
\text { ipoent cos } \\
\text { part less }\end{array}$ & $\begin{array}{l}F i \\
08 \\
n g i\end{array}$ & $\begin{array}{l}\text { 1 Year } 1982 \text { in thousand dollars. } \\
\text { site with shippiog vendor field } \\
\text { ring. } 3 \text {. This equipont is Appendix }\end{array}$ & $\begin{array}{l}\text { RUST: R } \\
\text { CHC: S } \\
\text { C Bulks }\end{array}$ & $\begin{array}{l}\text { Rust E } \\
\text { Stone }\end{array}$ & $\begin{array}{l}\text { ngineering } \\
\text { O Webster }\end{array}$ & $\begin{array}{l}\text { S: } \\
\text { P: } \\
\text { A: }\end{array}$ & $\begin{array}{l}\text { Schedul } \\
\text { Project } \\
\text { Actual }\end{array}$ & $\begin{array}{l}\text { led } \\
\text { led }\end{array}$ & & $\begin{array}{l}\text { FL: Field } \\
\text { n: Hateri } \\
\text { SF: Shop }\end{array}$ & $\begin{array}{l}\text { d Labor } \\
\text { ial for f } \\
\text { Fabricat. }\end{array}$ & $\begin{array}{l}\text { N/A: } \\
\text { Id fab } \\
\text { FE: Fie }\end{array}$ & $\begin{array}{l}\text { Applica } \\
\text { uiprent } \\
\text { li Fabric }\end{array}$ & hise \\
\hline
\end{tabular}


EQUIPAEKT LIST/SUMARY $\quad$ REV. 4 03-26-82

WBS ELEMIEMT: 1.4 .1 .1 .2 ICRC AREA: 16

COOLING WATER--COOLING TOWER 1

PAGE 3 OF 3

\begin{tabular}{|c|c|c|c|c|c|c|c|c|c|c|c|c|c|c|c|c|}
\hline \multirow[b]{2}{*}{ REV. } & \multirow{3}{*}{$\begin{array}{l}\text { ICRC/RUST } \\
\text { EQUIP NO } \\
x-16603\end{array}$} & \multirow{3}{*}{$\frac{\text { QTY }}{1}$} & \multirow{3}{*}{$\begin{array}{l}\text { EQUEPHENT } \\
\text { DESCRIPTIOH } \\
\text { Chlcrinator, } \\
6,0 \text { (c) lb/day }\end{array}$} & & \multirow{3}{*}{$\begin{array}{l}\text { P.O. } \\
\text { MUMBER }\end{array}$} & \multirow[b]{2}{*}{$\begin{array}{l}\text { SIZE/ } \\
\text { WEIGHT }\end{array}$} & \multirow{2}{*}{\multicolumn{2}{|c|}{$\begin{array}{l}\text { P.O. } \\
\text { DATE }\end{array}$}} & \multirow{2}{*}{\multicolumn{3}{|c|}{$\begin{array}{l}\text { VENDOR ENG } \\
\text { NEED } \quad \text { COST }\end{array}$}} & \multirow{2}{*}{\multicolumn{2}{|c|}{$\begin{array}{l}\text { DELV } \\
\text { DATE }\end{array}$}} & \multirow{3}{*}{$\frac{\begin{array}{l}\text { EQUIP } \\
\text { COST }\end{array}}{28.1}$} & \multirow{3}{*}{$\begin{array}{l}\begin{array}{c}\text { PURCH } \\
\text { BY }\end{array} \\
\text { RUST }\end{array}$} & \multirow{3}{*}{$\begin{array}{l}\text { TYPE } \\
\text { EQUIR } \\
\text { SF }\end{array}$} \\
\hline & & & & & & & & & & & & & & & & \\
\hline & & & & $\begin{array}{l}\text { cooling tower, } \\
\text { ax }\end{array}$ & & · & $\begin{array}{l}S \\
P \\
A\end{array}$ & $10-82$ & $\begin{array}{l}\mathbf{S} \\
\mathbf{P} \\
\mathbf{A}\end{array}$ & $11-82$ & 2.8 & $\begin{array}{l}\text { S } \\
\mathbf{P} \\
\mathrm{A}\end{array}$ & $3-83$ & & & \\
\hline
\end{tabular}

吕

NOTES:

1. All costs ist Quarter Fiscal Year 1982 in thousand dollars. Rust: Rust Englneering

CAC: Stone \& Webster

S: Scheduled
P: Projected

support less vendor engineering. 3. This equipoent is Appeadia C Bulks.
support

A: Actual

FL: Field Labor N/A: Not Applicable

H: Haterial for field fab equipene

SF: Shop. Fabicated FF: Field Fabricaced 


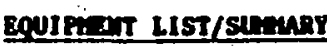

COOLING MATER--COOLINO TONER 2 ax. 5

02-06-84

PAGE 1 of 3

\begin{tabular}{|c|c|c|c|c|c|c|c|c|c|c|c|c|c|c|c|}
\hline \multirow{3}{*}{$\begin{array}{l}\text { REV. } \\
3\end{array}$} & \multirow{4}{*}{$\begin{array}{l}\text { ICRC/RUST } \\
\text { EQUIP Ro } \\
\text { C-16610 } \\
\text { A thru C } \\
\text { CT-16610 }\end{array}$} & \multirow{3}{*}{ on } & \multirow{3}{*}{$\begin{array}{l}\text { EQUIPAEIT } \\
\text { DEscriptIon }\end{array}$} & \multirow{3}{*}{$\begin{array}{l}\text { P.o. } \\
\text { muser }\end{array}$} & \multirow{3}{*}{$\begin{array}{l}\text { sizs/ } \\
\text { wight } \\
\begin{array}{l}125 \text { bp } \\
\times 3\end{array}\end{array}$} & \multirow{2}{*}{\multicolumn{2}{|c|}{$\begin{array}{l}\text { P.o. } \\
\text { Datt }\end{array}$}} & \multirow{2}{*}{\multicolumn{3}{|c|}{ 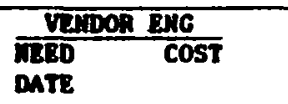 }} & \multirow{2}{*}{\multicolumn{2}{|c|}{$\begin{array}{l}\text { DELV } \\
\text { DATE }\end{array}$}} & \multirow{3}{*}{$\begin{array}{l}\text { EQUIP } \\
\text { cost } \\
\text { Ioc } \\
\text { wieh } \\
\text { CT- } 16610\end{array}$} & \multirow{3}{*}{$\frac{\operatorname{Pum}_{\mathrm{Br}}}{\operatorname{cosc}}$} & \multirow{3}{*}{$\frac{\begin{array}{l}\text { TrPe } \\
\text { EQuIP }\end{array}}{\Gamma}$} \\
\hline & & & & & & & & & & & & & & & \\
\hline & & & & & & $\begin{array}{l}\mathbf{s} \\
\mathbf{P} \\
\mathbf{A}\end{array}$ & $11-82$ & $\begin{array}{l}\mathbf{s} \\
\mathbf{p} \\
\mathbf{A}\end{array}$ & $1-83$ & $\begin{array}{l}\text { Inc } \\
\text { with } \\
\text { CT-16610 }\end{array}$ & $\begin{array}{l}\mathbf{s} \\
\mathbf{p} \\
\mathbf{A}\end{array}$ & $9-83$ & & & \\
\hline 5 & & $t$ & 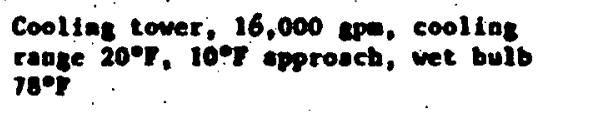 & & & $\mathbf{s}$ & $11-82$ & $\begin{array}{l}\mathbf{8} \\
\mathbf{P} \\
\mathbf{A}\end{array}$ & $1-83$ & 39.1 & $\begin{array}{l}\mathbf{8} \\
\mathbf{P} \\
\mathbf{A}\end{array}$ & $9-83$ & $\begin{array}{l}374.8 \\
H=29.4 .7 \\
L=80.1\end{array}$ & $\operatorname{cac}_{7}$ & FF \\
\hline \multirow[t]{2}{*}{$\vec{G}$} & $\begin{array}{l}F L-16610 \\
A \text { and } B\end{array}$ & 2 & 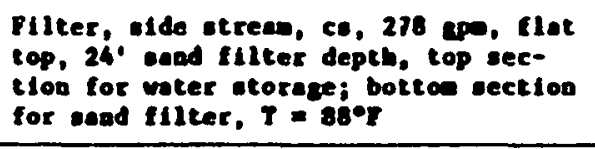 & & $\begin{array}{l}\text { 8' die x } \\
\text { 15.75' bigh }\end{array}$ & $\begin{array}{l}\mathbf{B} \\
\mathbf{P} \\
\mathbf{A}\end{array}$ & $10-82$ & $\begin{array}{l}\mathbf{B} \\
\mathbf{P} \\
\mathbf{A}\end{array}$ & $12-82$ & $3.3 \mathrm{es}$ & $\begin{array}{l}\mathbf{s} \\
\mathbf{p} \\
\mathrm{A}\end{array}$ & $5-83$ & $32.5 \mathrm{es}$ & gust & $\mathbf{S F}$ \\
\hline & $J-16610$ & 1 & $\begin{array}{l}\text { Bjector, calorine } \\
\text { (Inctuded with cbloringtor) }\end{array}$ & & & $\begin{array}{l}\mathbf{s} \\
\mathbf{p} \\
\mathbf{A}\end{array}$ & $10-82$ & $\begin{array}{l}\mathbf{s} \\
\mathbf{p} \\
\mathbf{A}\end{array}$ & $11-82$ & $\begin{array}{l}\operatorname{inc}_{u t h} \\
x-16612\end{array}$ & $\begin{array}{l}\mathbf{s} \\
\mathbf{p} \\
\mathbf{A}\end{array}$ & $3-83$ & $\begin{array}{l}\text { inc } \\
\text { with } \\
x-16612\end{array}$ & RUST & $\mathbf{s F}$ \\
\hline & $\begin{array}{l}P-16610 \\
A \text { and B }\end{array}$ & 2 & 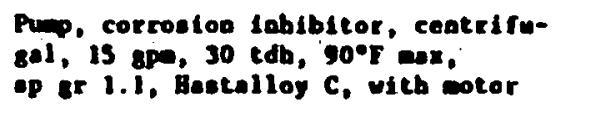 & & $\begin{array}{l}1 \text { bp } \\
1,800 \text { rpe }\end{array}$ & $\begin{array}{l}\mathbf{8} \\
\mathbf{P} \\
\mathbf{A}\end{array}$ & $10-82$ & $\begin{array}{l}\mathbf{s} \\
\mathbf{p} \\
\mathbf{A}\end{array}$ & $11-82$ & $0.6 \mathrm{es}$ & $\begin{array}{l}\mathbf{s} \\
\mathbf{p} \\
\mathbf{A}\end{array}$ & $2-83$ & $4.7 \mathrm{es}$ & RUST & $\mathbf{s F}$ \\
\hline & $\begin{array}{l}P-16611 \\
A \text { and B }\end{array}$ & 2 & 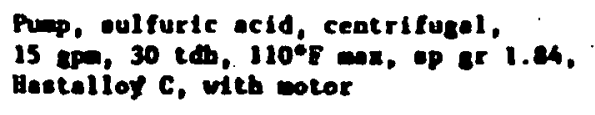 & & $\begin{array}{l}1 \mathrm{hp} \\
1,800 \mathrm{rpm}\end{array}$ & $\begin{array}{l}\mathbf{8} \\
\mathbf{P} \\
\mathbf{A}\end{array}$ & $10-82$ & $\begin{array}{l}\mathbf{s} \\
\mathbf{p} \\
\mathbf{A}\end{array}$ & $11-82$ & $0.6 \mathrm{es}$ & $\begin{array}{l}\mathbf{s} \\
\mathbf{P} \\
\mathbf{A}\end{array}$ & $2-83$ & $4.7 \mathrm{es}$ & RUST & SF \\
\hline & $\begin{array}{l}\text { P-16612 } \\
\text { AbruE }\end{array}$ & 5 & 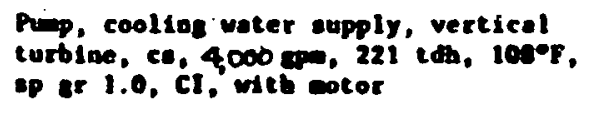 & & $\begin{array}{c}300 \text { up oa. } \\
\text { rpa }\end{array}$ & $\begin{array}{l}8 \\
P \\
A\end{array}$ & $10-82$ & $\begin{array}{l}\mathbf{s} \\
\mathbf{p} \\
\mathbf{A}\end{array}$ & $11-82$ & $7.2 \mathrm{cos}$ & $\begin{array}{l}\text { s } \\
\text { p } \\
\text { A }\end{array}$ & $2-83$ & $30.8 \mathrm{ee}$ & must & $\mathbf{s r}$ \\
\hline 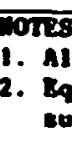 & $\begin{array}{l}\text { pent cos } \\
\text { ort less }\end{array}$ & & $\begin{array}{l}\text { Year } 1982 \text { In tbousend dollars. } \\
\text { ite vitb shipplas } 8 \text { vendor lield } \\
\text { ing. 3. This eguipaent is Appendix }\end{array}$ & $\begin{array}{l}\text { RUST: Re } \\
\text { CWC: st } \\
\text { C Eaits. }\end{array}$ & $\begin{array}{l}\text { Engineerios } \\
\text { c. Webster }\end{array}$ & $\begin{array}{l}\text { 8: } \\
\text { P: } \\
\text { A: }\end{array}$ & $\begin{array}{l}\text { Schedu } \\
\text { Projec } \\
\text { Actuol }\end{array}$ & $\begin{array}{l}\text { led } \\
\text { ced } \\
\text {. }\end{array}$ & & $\begin{array}{l}\text { FL: Field } \\
\text { M: Hatert } \\
\text { SF: Shop }\end{array}$ & & $\begin{array}{l}\text { abor } \\
\text { for } \\
\text { bricet }\end{array}$ & $\begin{array}{l}\text { M/A: Wot } \\
\text { Id fab equi } \\
\text { FF: Field }\end{array}$ & $\begin{array}{l}\text { Appl } \\
\text { ipaeat } \\
\text { ld Fob. }\end{array}$ & $\begin{array}{l}\text { ble } \\
\text { aced }\end{array}$ \\
\hline
\end{tabular}




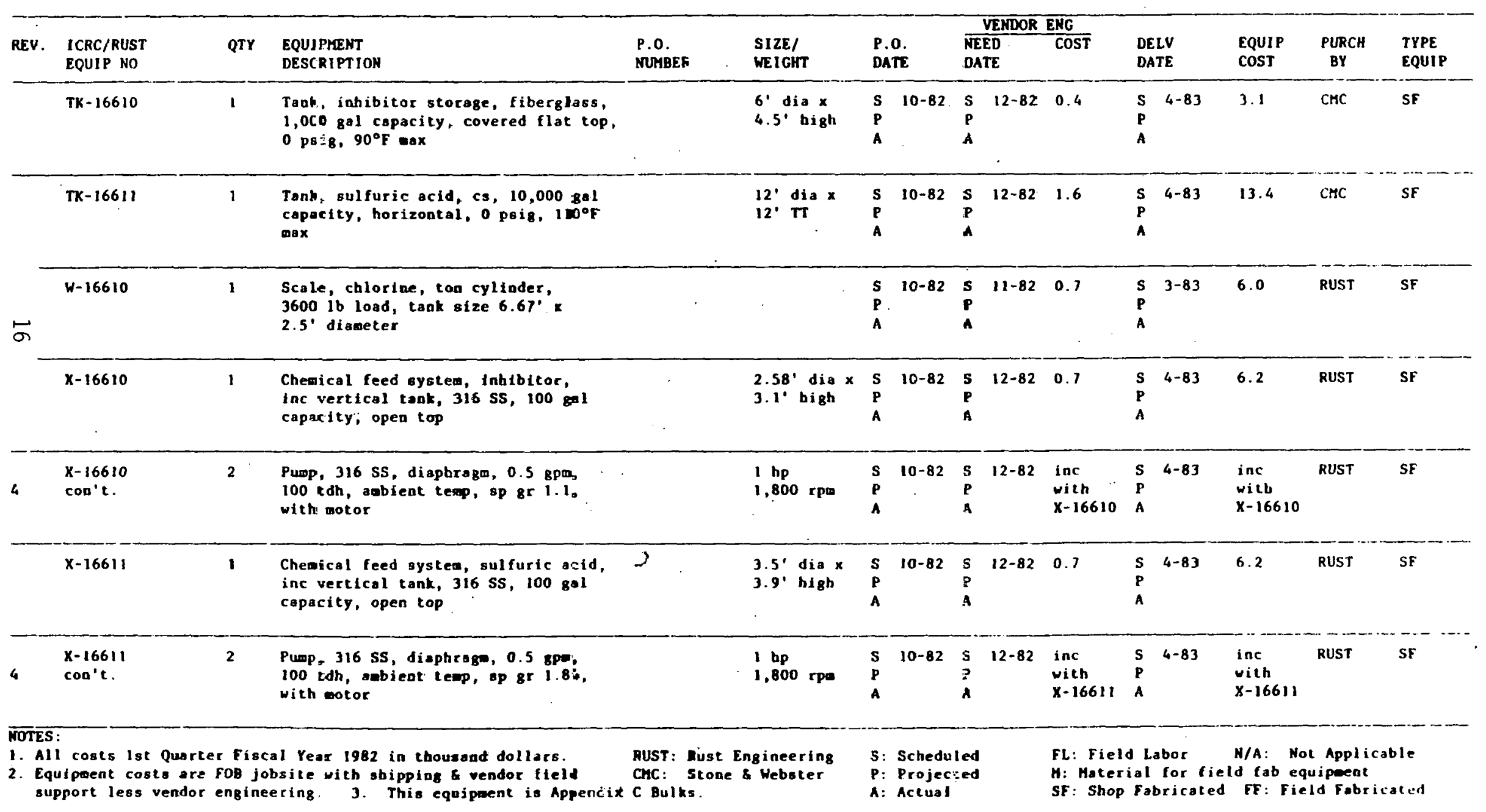


EQUIPHEMT LIST/SUMURY REV. 4 03-26-82

COOLING WATER--COOLING TOWER 2
PAGF 3 OF 3

P.0.
MUNBER

SIZE/
WEIGITT

P.o. $\frac{\text { VEMDOR ENG }}{\text { MEED }}$

NEED DATE DATE

10-82

S $11-82 \quad 1: 7$

$\mathrm{x}-16612 \quad \begin{aligned} & \text { Cblorinator, cooling tower, } \\ & 1200 \mathrm{lb} / \mathrm{day} \text { max }\end{aligned}$

$\mathrm{X}-16612 \quad \begin{aligned} & \text { Cblorinator, cooling tower, } \\ & 1200 \mathrm{lb} / \mathrm{day} \text { max }\end{aligned}$

TYPCH BV EQUIP

DELT

$\mathbf{S}$
$\mathbf{P}$
$\mathbf{A}$

•

NOTES :

1. All costs lat Quarter Fiscal Year 1982 in thousand dollars. RUST: Rust Engineering : Equiparat costs are $\mathrm{FOB}$ Jobsite with shipping vendor field . CHC: Stone 8 Webster support less vendor engineering.
3. This equipsent is Appendix C Bulks.
S: Scheduled

P: Projected

A: Actual
FL: Field Labor N/A: Hot Applicable

for field fob equipenet

SF : Shop Fabricaled Fr: Fleld Fabricated 
EQUIPHENT LIST/SUITLARY REV. 4 03-26-82

i3. E EN DISTRIBUTION--SUBSTATIOH NO. 7

\begin{tabular}{|c|c|c|c|c|c|c|c|c|c|c|c|c|c|c|}
\hline \multirow{3}{*}{ REV. } & \multirow{3}{*}{$\begin{array}{l}\text { ICRC/RUST } \\
\text { EQUIP NO } \\
\text { CA-17014 } \\
\text { A }\end{array}$} & \multirow{3}{*}{ QTY } & \multirow{3}{*}{ 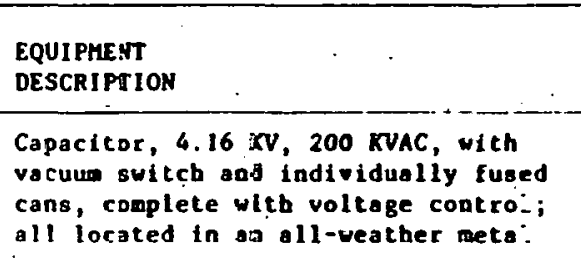 } & \multirow{3}{*}{$\begin{array}{l}\text { P } 0 . \\
\text { NEMBER }\end{array}$} & \multirow{3}{*}{$\begin{array}{l}\text { SIZE/ } \\
\text { WEIGHT }\end{array}$} & \multirow{2}{*}{\multicolumn{2}{|c|}{$\begin{array}{l}\text { P.O. } \\
\text { DATE }\end{array}$}} & \multirow{2}{*}{\multicolumn{2}{|c|}{$\begin{array}{l}\text { VENDOR } \\
\text { NEED } \\
\text { DATE }\end{array}$}} & \multirow{3}{*}{$\begin{array}{l}\text { ENG } \\
\operatorname{COST} \\
\text { inc } \\
\text { ith } \\
\text { IR-17010 }\end{array}$} & \multirow[b]{2}{*}{$\begin{array}{l}\text { DELV } \\
\text { DATE }\end{array}$} & \multirow{3}{*}{$\begin{array}{l}\begin{array}{l}\text { EQUIP } \\
\text { COST }\end{array} \\
\text { inc } \\
\text { with } \\
\text { TR-17010 }\end{array}$} & \multirow{3}{*}{$\begin{array}{c}\begin{array}{c}\text { PURCH } \\
\text { BY }\end{array} \\
\text { CHC } \\
-\end{array}$} & \multirow{3}{*}{$\begin{array}{l}\text { TYPE } \\
\text { EQUIP } \\
\text { SF }\end{array}$} \\
\hline & & & & & & & & & & & & & & \\
\hline & & & & & & $\begin{array}{l}\text { S } \\
\mathbf{P} \\
\mathbf{A}\end{array}$ & $11-82$ & $\begin{array}{l}S \\
P \\
A\end{array}$ & $3-83$ & & $\begin{array}{l}S \quad 6-83 \\
P \\
A\end{array}$ & & & \\
\hline .. & $\begin{array}{l}\text { CA-17014 } \\
\text { con't. }\end{array}$ & & $\begin{array}{l}\text { enclosure with conduit entrance frem } \\
\text { sottom }\end{array}$ & & & & & & & & & & CMC & SF \\
\hline \multirow{5}{*}{$\omega$} & $\begin{array}{l}\text { GR-17012 } \\
\text { A }\end{array}$ & 1 & $\begin{array}{l}\text { Resistor, neutral grounding, rated } \\
2,400 \text { wits, } 400 \text { amperes for } 10 \text { see- } \\
\text { onds; complete with mounting frane snd } \\
\text { screen enclosure. }\end{array}$ & & & $\begin{array}{l}\mathbf{S} \\
\mathbf{P} \\
\mathbf{A}\end{array}$ & $7-83$ & $\begin{array}{l}\mathbf{s} \\
\mathbf{P} \\
\mathbf{A}\end{array}$ & $11-83$ & $\begin{array}{l}\text { foc } \\
\text { with } \\
\text { DR-17010 }\end{array}$ & $\begin{array}{ll}S & 5-84 \\
P & \\
A & \end{array}$ & $\begin{array}{l}\text { inc } \\
\text { with } \\
\text { TR-17010 }\end{array}$ & CMC & SF \\
\hline & AC- 17013 & 1 & $\begin{array}{l}\text { Hotor control ceater, mediü voltage, } \\
4.16 \mathrm{w} \text {, manh type I, uith incoming } \\
\text { line wdule and terminal lugs }\end{array}$ & & & $\begin{array}{l}\mathbf{S} \\
\mathbf{P} \\
\mathbf{A}\end{array}$ & $11-82$ & $\begin{array}{l}\mathbf{S} \\
\mathbf{P} \\
\mathbf{A}\end{array}$ & 3-83 & 15.5 & $\begin{array}{ll}\text { S } & 6-83 \\
\text { P } & \\
\text { A } & \end{array}$ & 131.2 & смС & SF \\
\hline & $\mathrm{MC}_{\mathrm{A}}^{\mathrm{HC}} 17017$ & $I$ & $\begin{array}{l}\text { Hotor control cester, } 0.48 \mathrm{kV} \text {, NEMa } \\
\text { type I with incoming lige wodule and } \\
\text { terminal lugs }\end{array}$ & & & $\begin{array}{r}s \\
\mathbf{P} \\
\mathbf{A}\end{array}$ & $11-82$ & $\begin{array}{l}\mathbf{S} \\
\mathbf{P} \\
\mathbf{A}\end{array}$ & $3-83$ & $\begin{array}{l}\text { inc } \\
\text { with } \\
\text { in- }-17013\end{array}$ & $\begin{array}{ll}\text { S } & \text { 6-83 } \\
\text { P } & \\
\text { A } & \end{array}$ & $\begin{array}{l}\text { inc } \\
\text { with } \\
\text { MC-17013 }\end{array}$ & CAC & SF \\
\hline & $\begin{array}{l}\text { SG-17011 } \\
A\end{array}$ & 1 & $\begin{array}{l}\text { Switchgear, } 3 \text { phase, } 4.16 \mathrm{KV}, 1,200 \\
\text { ampere located in an outdoor, pro- } \\
\text { tected-isle, all-weather metal } \\
\text { enclosure, complete with CPT, CT'a. }\end{array}$ & & & $\begin{array}{l}\mathbf{S} \\
\mathbf{P} \\
\mathbf{A}\end{array}$ & $11-82$ & $\begin{array}{l}\mathbf{S} \\
\mathbf{p} \\
\mathbf{A}\end{array}$ & 3-83 & 3.6 & $\begin{array}{ll}S & 6-83 \\
\text { P } & \\
\text { A } & \end{array}$ & 30.4 & $\mathrm{CHC}$ & $\mathbf{s F}$ \\
\hline & $\begin{array}{l}\text { so-17011 } \\
\text { con't. }\end{array}$ & & $\begin{array}{l}\text { and PT's for load eetering, de power } \\
\text { supply if required, (2) relay and } \\
\text { meteriog cubicles in addition to } \\
\text { breaker cubicles, and provisions for }\end{array}$ & . & & & . & . & & & & & $\mathrm{CHC}$ & sF \\
\hline $\begin{array}{l}\text { BOTES } \\
\text { 1. Al } \\
\text { 2. Eq } \\
\text { 84 }\end{array}$ & $\begin{array}{l}\text { coses lat } \\
\text { poent cost } \\
\text { port less }\end{array}$ & $\begin{array}{l}\text { r Fis } \\
\text { FoB j } \\
\text { engin }\end{array}$ & $\begin{array}{l}\text { al Year } 1982 \text { in lbousand dolitars. } \\
\text { bsite with shippins s vendor fleld } \\
\text { ering. 3. This equipmeat is Appendix }\end{array}$ & $\begin{array}{l}\text { Rast: R } \\
\text { CrC: } S \\
\text { C Bulks }\end{array}$ & $\begin{array}{l}\text { st Engineering } \\
\text { one } 8 \text { Webster }\end{array}$ & $\begin{array}{l}\text { S: } \\
\text { P: } \\
\text { A: }\end{array}$ & $\begin{array}{l}\text { Schedu } \\
\text { Projec } \\
\text { Actual }\end{array}$ & $\begin{array}{l}\text { led } \\
\text { ted }\end{array}$ & & $\begin{array}{l}\text { F.t: Field } \\
\text { n: Materi } \\
\text { SF: Shop }\end{array}$ & $\begin{array}{l}\text { d Labor } \\
\text { ial for } \\
\text { Fabrica }\end{array}$ & $\begin{array}{l}\text { W/A: Mot } \\
\text { 1d fab equ } \\
\text { TT: Fiel }\end{array}$ & $\begin{array}{l}\text { Applic: } \\
\text { uipment } \\
\text { Id Fabr }\end{array}$ & le \\
\hline
\end{tabular}




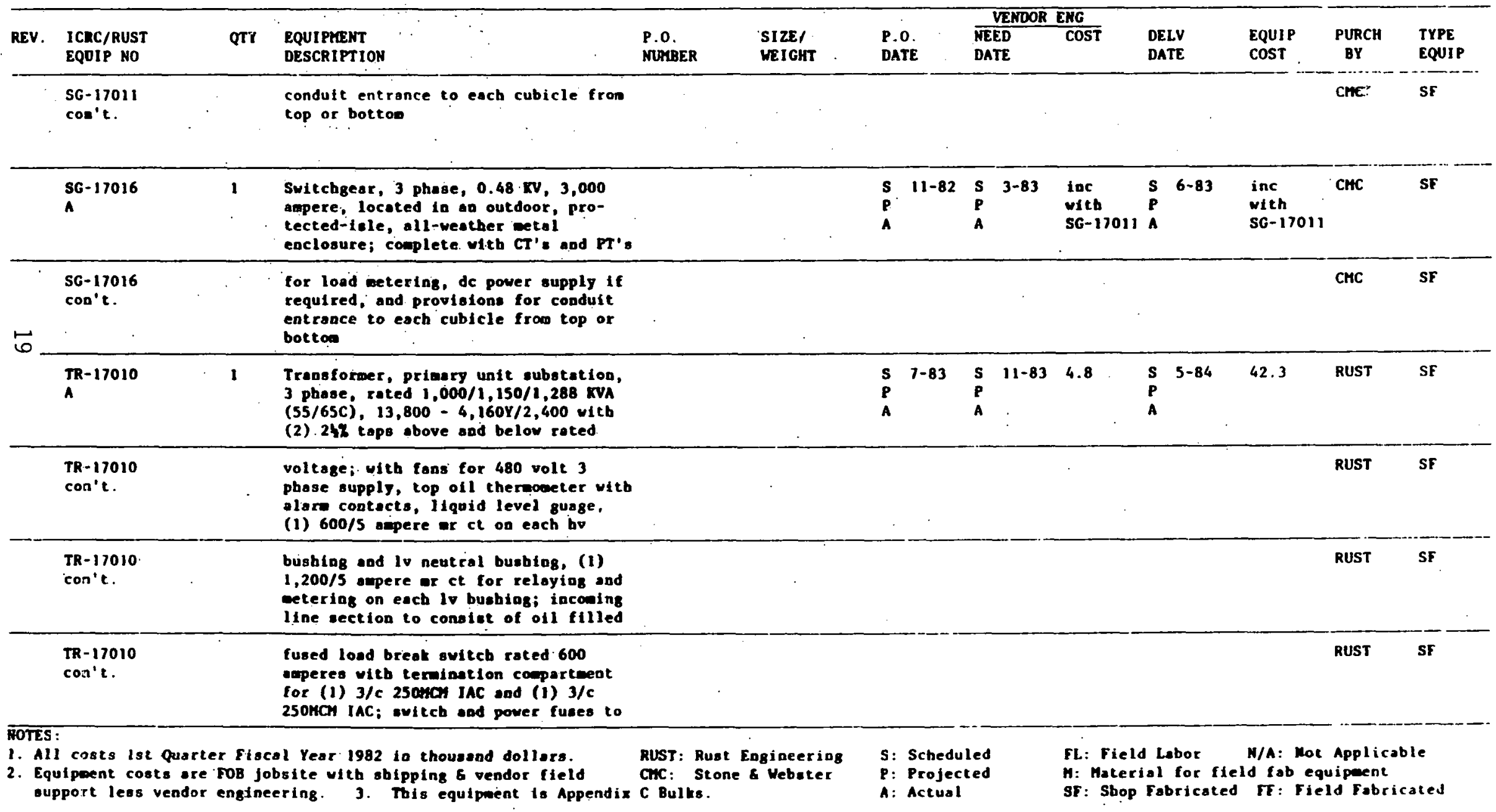



EOUIPYEHT LIST/SUMMARY
REV. \&
$03-26-82$

WBS EIEHENT: 1.4.1.2.1 ICRC AREA: 17

$13.8 \mathrm{KV}$ DISTRIBUTION--SUBSTATION NO.

PAGE 3 OF 3

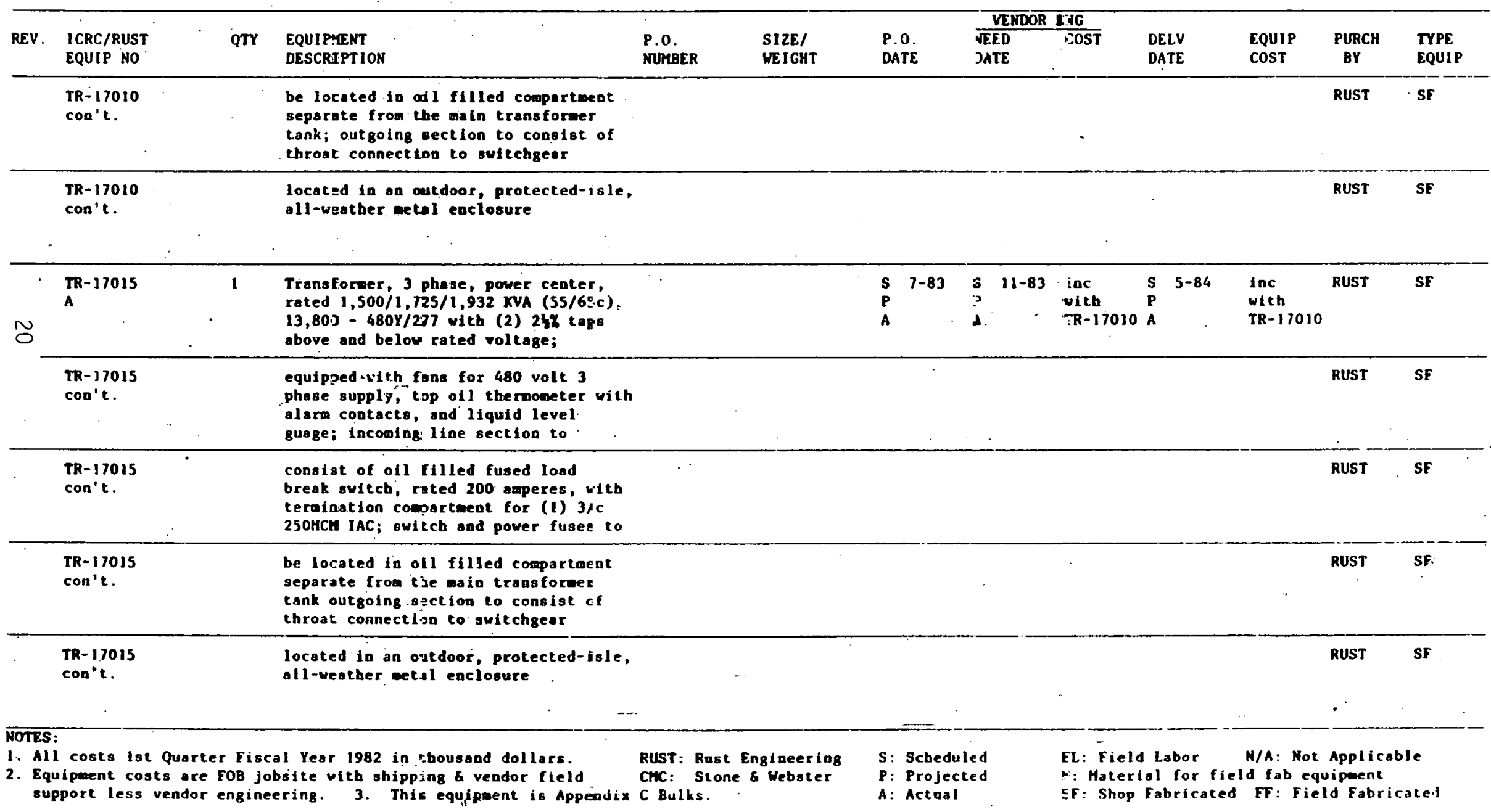


EQUIPHENT LIST/SUTPARY $\quad$ REV. $4 \quad 03-26-82$

WBS ELERENT: 1.4 .1 .1 .2 ICRC AREA: 16

$13.8 \mathrm{kV}$ DISTRIBUTION--SUBSTATION NO. 9

PAGE 1 OF 3

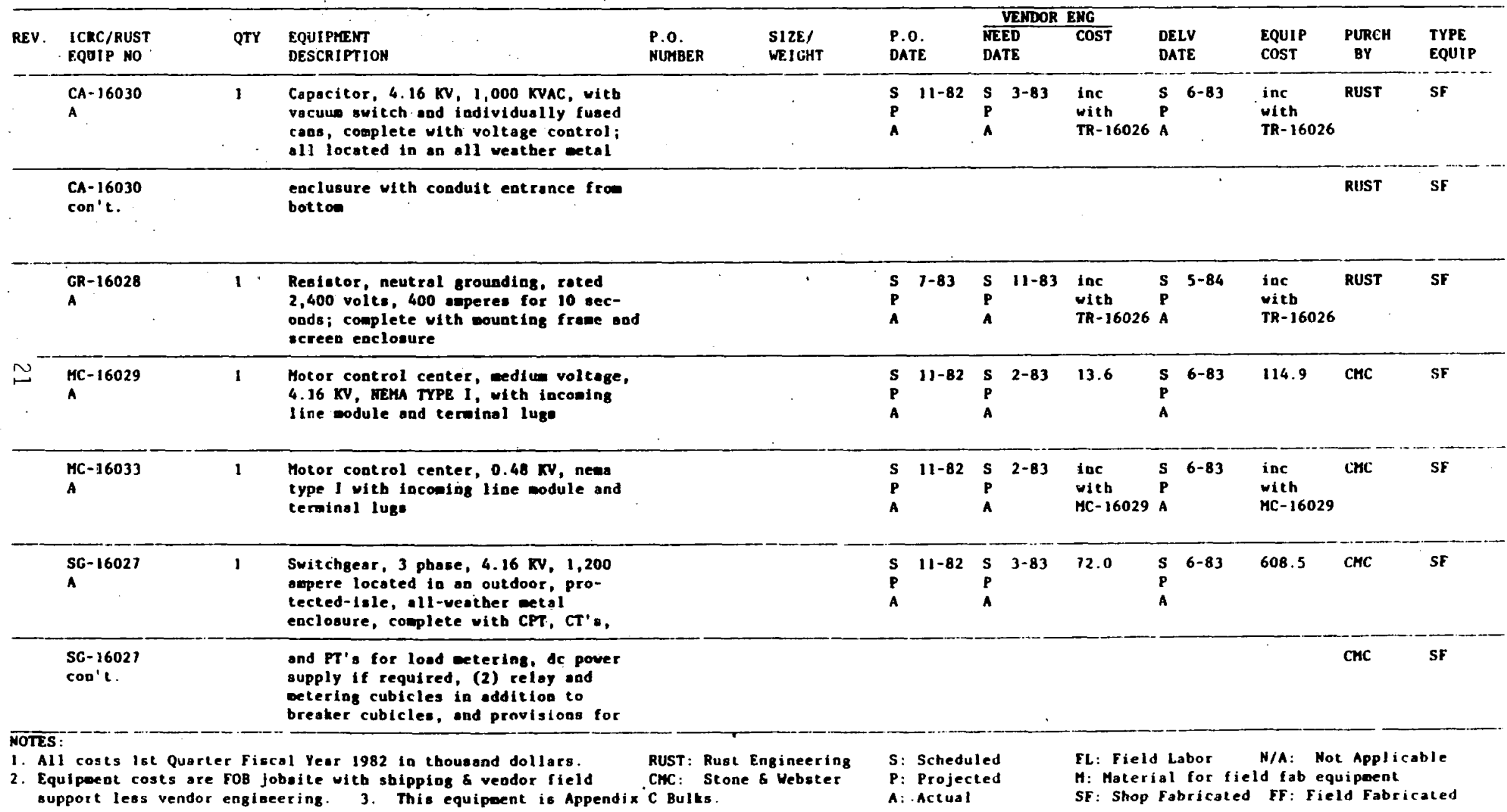


EQUIPIENT LIST/SUMAARY REV. $4 \quad$ 03-26-82

WBS ELEMENT: 1.4 .1 .1 .2 ICRC AREA: 16

$13.8 \mathrm{kV}$ DISTRIBUTION--SUBSTATION NO. 9

PAGE 2 OF 3

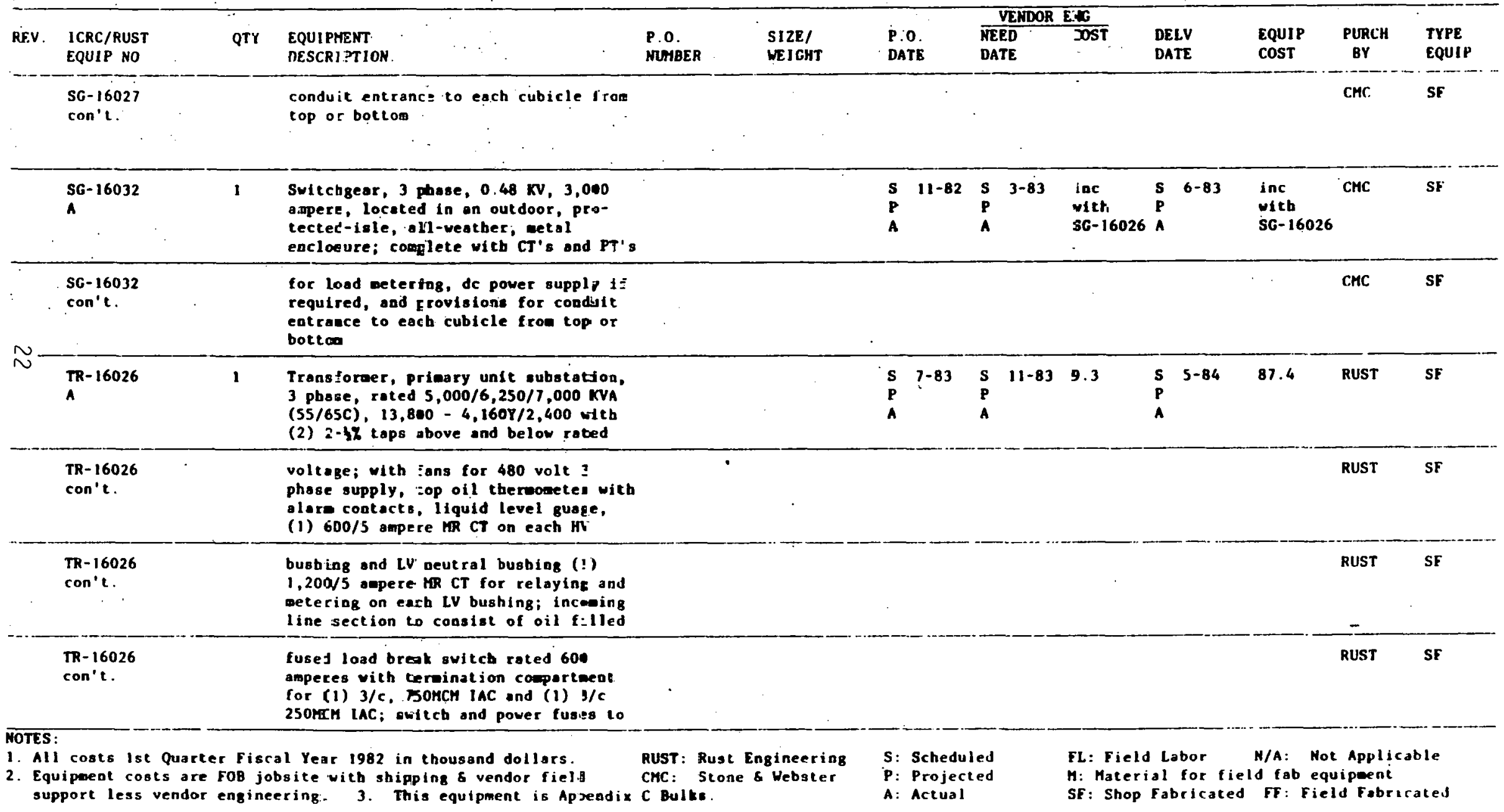


EQUIPMENT LIST/SUMAARY REV. $4 \quad 03-26-82$

WBS ELERENT: 1.4 .1 .1 .2 ICRC AREA: 16

13.8 KV DISTRIBUTION--SUBSTATION NO. 9

PAGE 3 OF 3

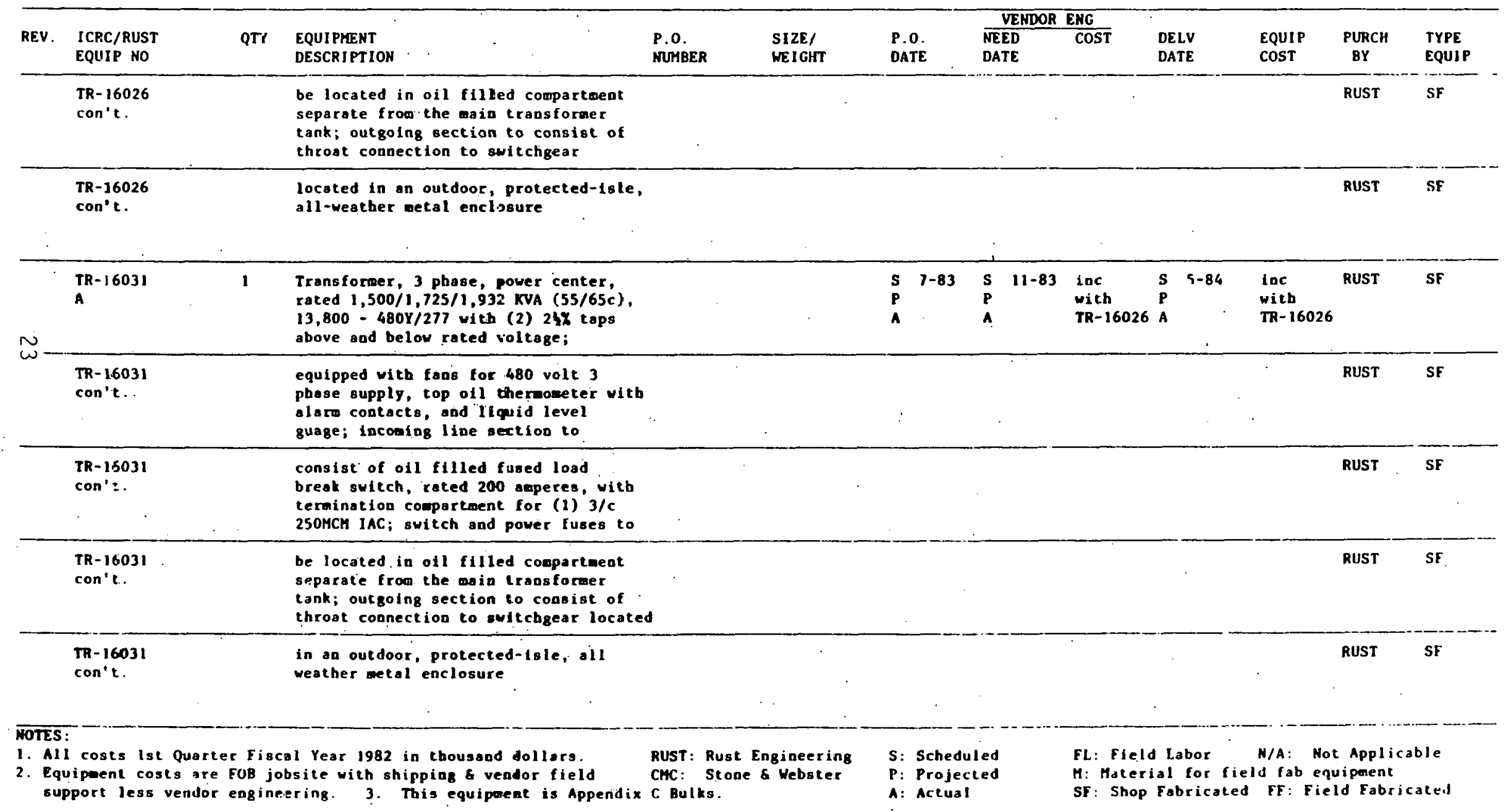




\subsubsection{Equipment Data Sheets}

The equipment data sheets for the cooling tower system follow this page. 


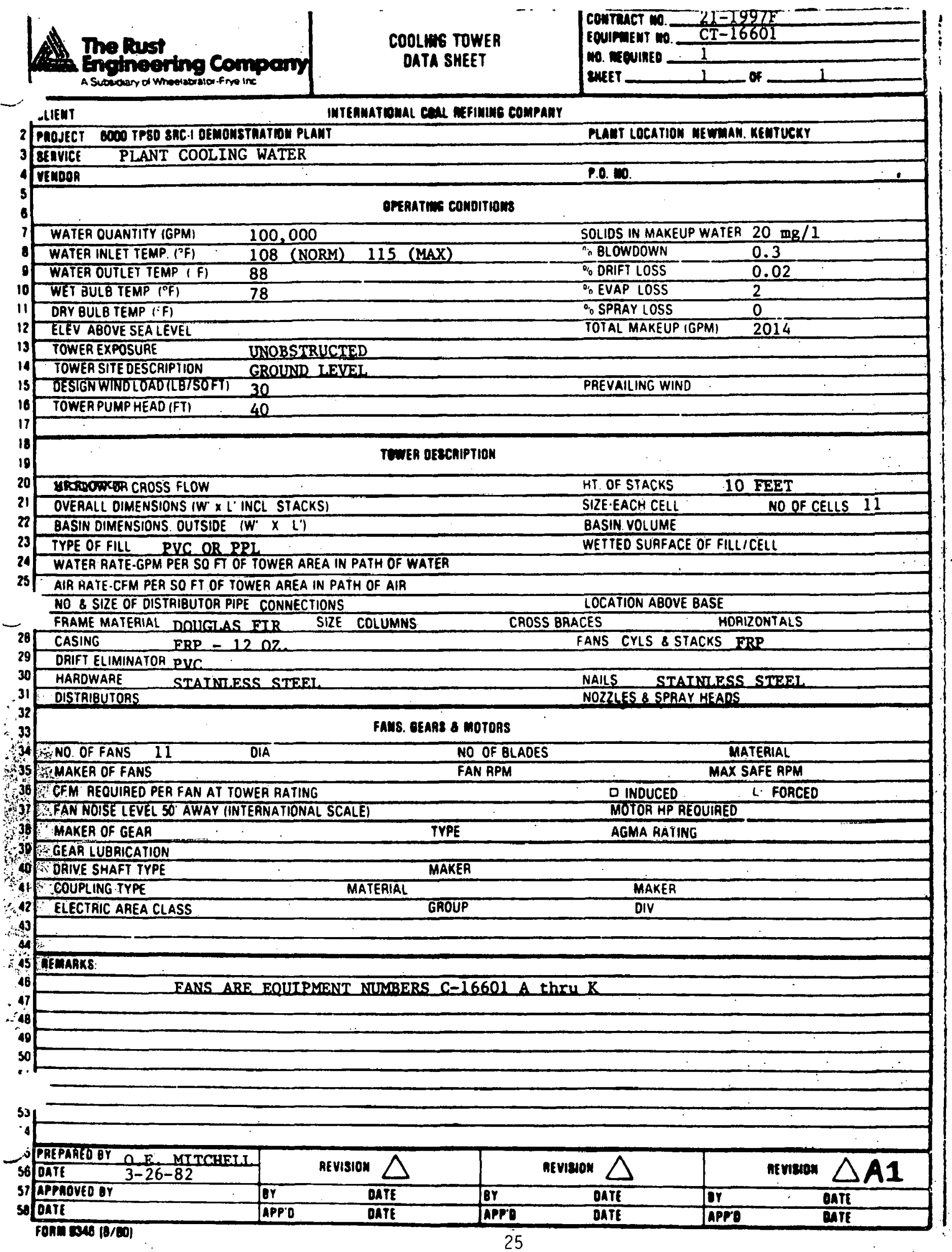




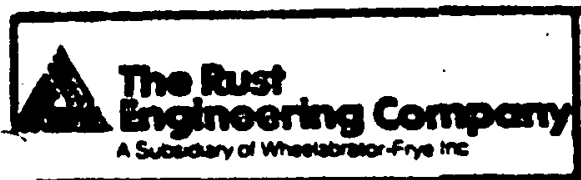

1 CLIENT

1 PROJECT COON TPBO BAC. OEROMBTMTION PLAMT

3 BITICE ASU COOLING WATRR

4 rewoon

s)

1 WATER OUANTITY (GPMI

WATER INLET TEMP. IPFI

WATEA OUTLET TEMP (F)

10 WET BULB EEMP (OF)

11 DAY BULB TEMP ('F)

12 ELEV. ABOVE SEA LEVEL

1) TOWEA EXPOSUAE

14 TOWLASITEDESCAIPTION

18 DESIdNWINOLOROLIEISOTI

10 TOWEATUMP HEAOIFT)

10

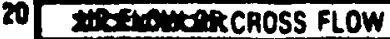

21 OVERALL DIMENSIONS (W $\times$ L'INCL STACKS)

22 BASIN DIMEMSIONS. OUTSIDE (W $\left.\times L^{\prime}\right)$

23 TYPE OF FILL PVC OR PPI

24 WATEA RATE-GPM PER SO FT OF TOWER AREA IN PATH OF WATEA

14 AR RATE.CFM PER SO FT OF TOWER AAEA IN PATH OF AIA

MO. \& SILE OF DISTRIBUTOA PIPE CONMECTIONS

- FaAME MATEAIAL DOUYGLAS EIR SILE COLVMLIS

28 CASING FRP -1202.

20 DAIF ELIMINATOR PVC

30 HAROWAAE STAINLESS STEEI

31 DISTAIBUTORS

32

33

34

33

30 CFM REOUIAED PER FAN AT TOWER RATING

37 FAN WOISELEVEL SO' AWAY IIN ERNATIONAL SCALE)

39. MAKEA OF GEAR

30 GEAR LUBRICATIOH

40 DRIVE SHAFT TYPE

41 COUPLING TYPE

12 ELECTAIC AREA CLASS

45

4

45 mimank8:

40

47

4

40

sol

4
COOLIWS TOWER

DATA SHEET

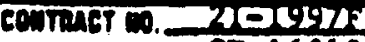

cownent m. CT-16610

Bo. inverese 1

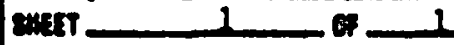

PUMT LOCAPLON MEWAAK. RLGTUERT

ค.o. 1.0.

Orenatus conoltume

Turen osechtirton

HT. OF STACKS 10 BRET

SIZE.EACH CELL

BASIN VOLUME

SOLIDS IN MAKEUP WATER $20 \mathrm{mo} / 1$

DO BLOWDOWN 0.3

$\because$ DRIFT LOSS -0.2

$\%$ EVAP LOSS 2

OS SPRAY LOSS 0

TOTAL MAKEUP (GPM) $\quad 349$

PAEVAILINO WINO

WETTEO SURFACE OF FILL/CELL

LOCATION ABOVE BASE

CAOSS BRACES MOAIZOMTALS

FANS CYLS \& STACKS IRP

NAILS STATNTIRSS STEMRT

NOZZLES P SPRAY HEAOS

Fand. G5ane s morohs

NO OF BLADES

FAN APM

MATERIAL

MAX SAFE RPM

- IMOUCED L. FORCSBO

WOTOR HP REOUIRED

AGMA RATING

IYPE

MAKEA

DIV.

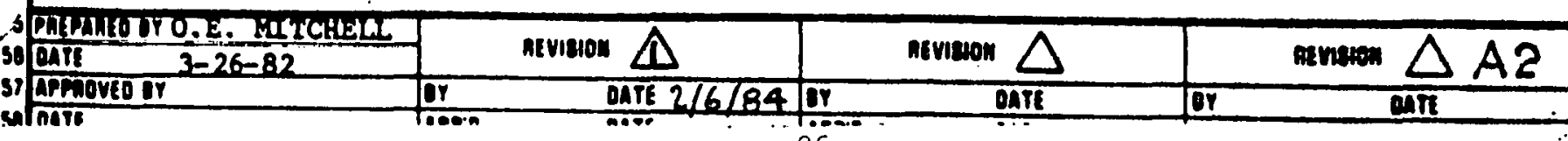

3) APriaver ar

26 


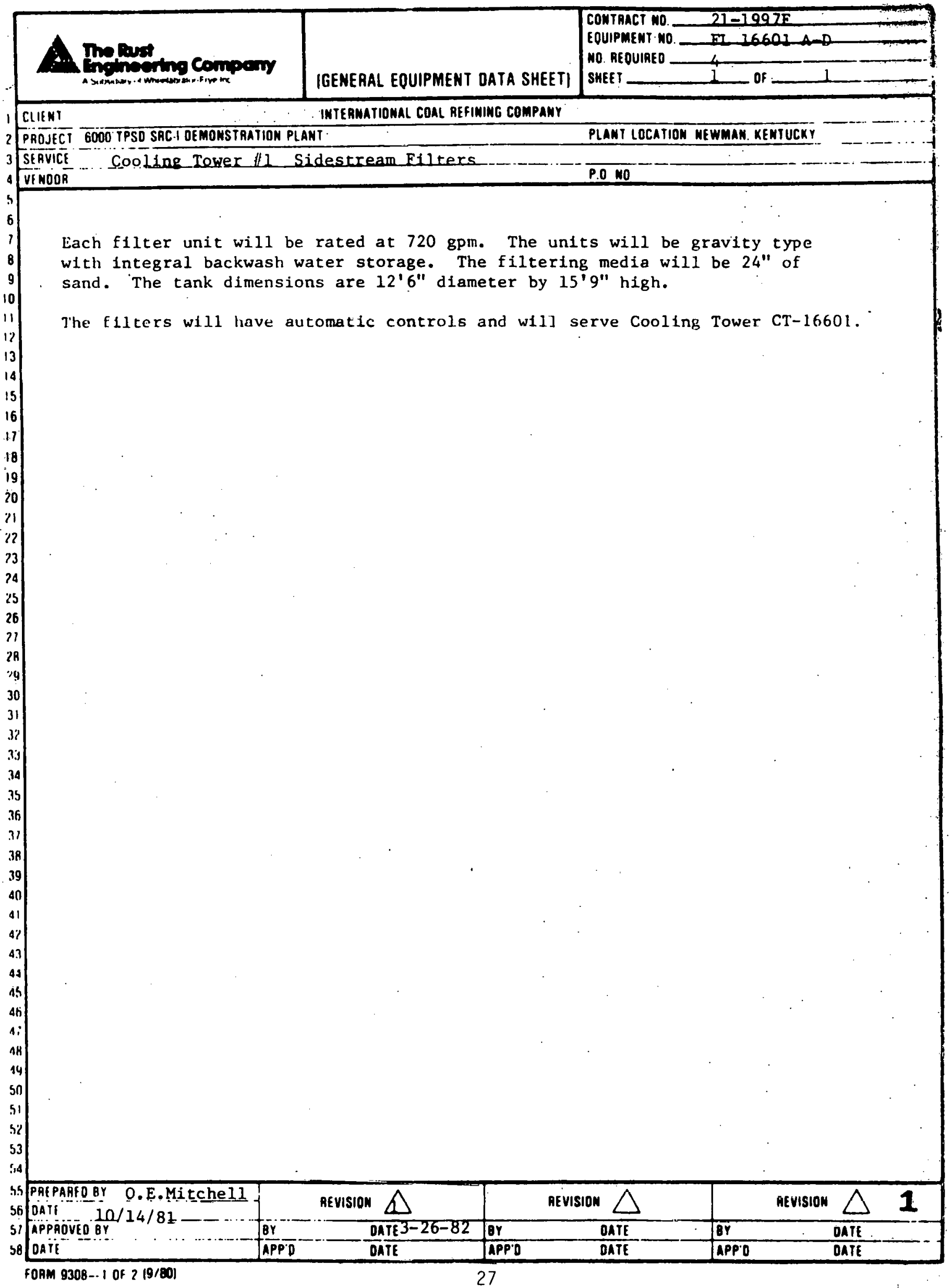




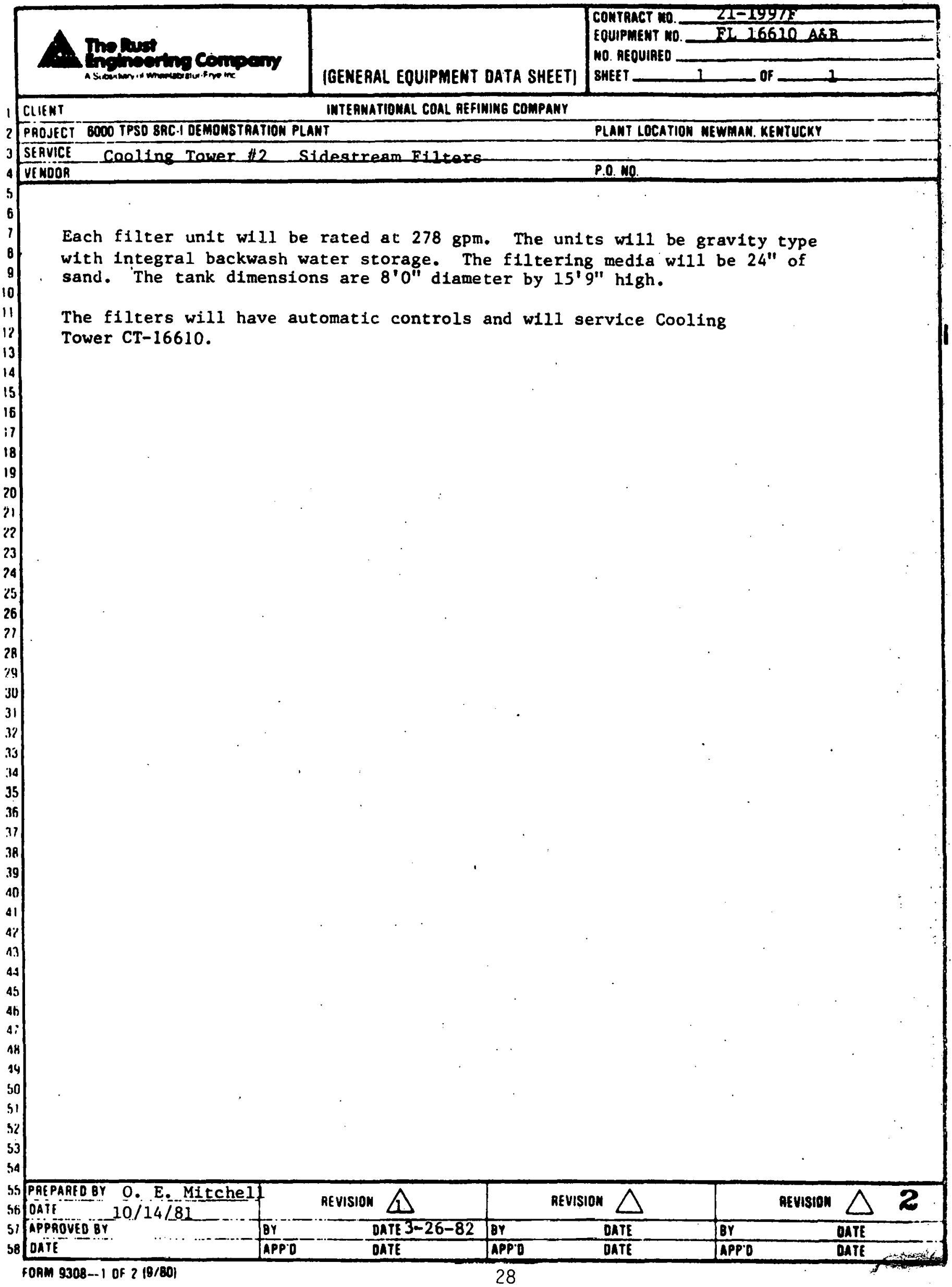



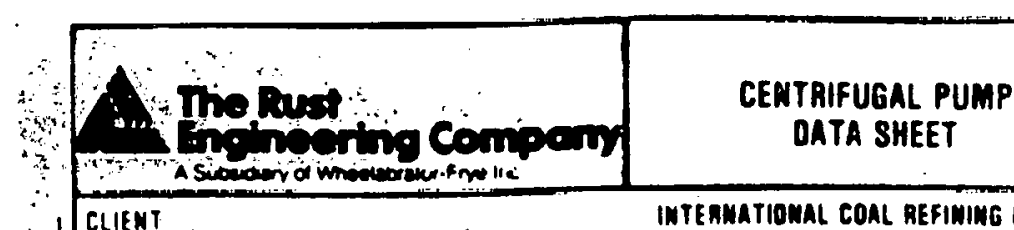

INTERMATIONAL COAL REFIWIMG COMPAMY

CLIEN

6000 TPSO SAC.I DEMOMSTRATION PLAMT

3 SERVICF Corrosion Inbibitor Trandex Pupo

VEMOOR

5 TYPE

MODEL

MO. OF MOTORS AEO'O

2

ITEM MO.

MO OF, TURBIMES REQ'O

ITEM MO

nonel

9 CI OPERATIMG COMOITIONS (EACH PUMP)

10 L.10U10 Corrosion Inh INS GPM AT PT NOR

DISCHARGE. PSIG 15,2

RATED 15

MAX 90 SUCIIUN PSIG MAX 2 RATEO 1

i2 PI F NOH 1.1 DIFF PAESS. PSI 14.2

13 SP GR AT PI

VAP PAESS AI PT PSIA_DIFF HEAD FT $\frac{30}{30}$
VIS AT PI LBIMI/FT-HR_ NPSHA FT 30

i6 CORAJEAOS CAUSED BY

17

i8 NOZZLES

19 SUCTION

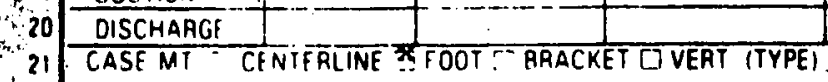

CONSTAUCTION

SPIII : AXIAL - RAD TYPF VOLUTE: SGL $\square$ DBL DOIFFUSER

PRESS MAY AILOW _ PSIG _ F DHYDRO TEST

CONNECT: VENT :-: ORAIN $=$ GAUGE L STEAM JACKET

IMPELLER DIA " RATEO
MOUNT $T$ BETWEEN BRGS $J$ OVERHUNG

BEARINGS TYPE " RADIAL

$\square$ THRUST

LUBE: : RING OIL Z: FLOOD $:^{-}$OIL MIST $\Xi F L I N G E R$ C PRESSURE

COUPLING $\because$ MFH" LI MOOEL

DAIVER HAI F MTO BY II: PUMP MFR I DAIVER MFR

$\triangle M E C K$ SEAL OPACKINC O AUX SEALIPACKING

MFA TYPE MODEI

MFH CODE

35 T:CW PIPE PLAN ¿ CU CSS ITUBING

10TAL COOL ING WATER REO O GPM

OPIPE

\section{.}

PACKING COOL INJECTION AEOO

38 ¿ SEAL FLUSH PIPE PLAN 11 DCS OS.S. O TUBING $\$$ PIPE

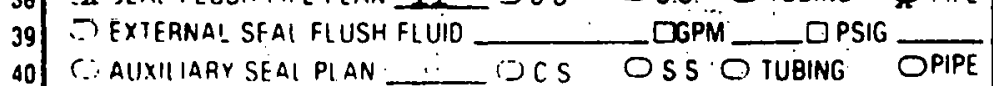

40 C AUXIIIARY SEAL PI AN

41 AUX SEAL FLUSHIOUENC:H FLUIO

43 PUMI TASE IRIM API CIASS MAERIALS

IASING Hastr.lloy C COAR ALL

IN

IMPE LIERHastel loy C WEAR RINGS

SHAF I Hastel loy $\mathrm{C}$ SLEEVEISI Hasce l Lay $C$

C.ASE INT COATING/LINING

GLANO

BASEPLATE

DRIP PAN

(2) S!IE CONOITIONS

SO ELEVATION FT DUSTIFUMES

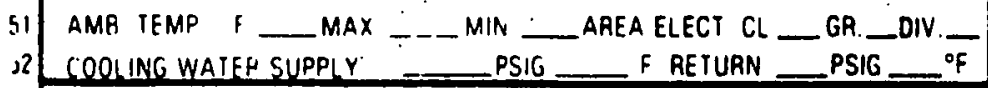

53 AE MAAKS.

54

S5 PREPARED BY R, Sciascia

56 DATE

Revision $\triangle$

57 APPROVEOBYY

$10=15-81$

SB OATE

$\frac{T_{B Y}}{\text { TAPPO }}$

$\frac{\text { BY }}{\text { TAPPD }}-\frac{\text { OATE }}{\text { OATE }}$

COAM $9318 / 5 / 60 \mid$

PLAMT LOCATION MEWMAN KEMTUCKY

CONTRACT $10.21-1997 / \mathrm{F}$

EOUIPMENT HO. P16602A/B

NO. AEOUIAEO 2

SHEET

OF

P.O. NO

SERIAL NO.

FURK. BY Purchaser MFR BY

BY MANUFACIUAER

DPEAFORMANCE

PAOPOSAL CURVE NO

APM NO OF STAGES

NPSHR FT \& IMPELLER IOF

EFF —BHP RAIED

MAX BHP RATED IMP

MAX HEAD RATED IMP

MIN CONTINUOUS GPM

ROTATION IVIEWED FROM CPLG END

OIMSPECTION AMO TESTS

SHOP INSPECTION C REOD

HYOROSTATIC TEST $\$$ REOD WITNESS

PERFORMANCE TEST -I REOD $\odot$ WITNESS

NPSH TES I

INT INSP AFTER

ORFOD $\because$ WITNESS

TEST

OREOD $\cdots$. WIINFSS

OREOD O WITNESS EIMT. WEAR PARTS

WEAR RINGS $こ$. CASE IIMP

DIA___ IN CLEARANCE _ IN

INTERSIAGE BUSHINGS

DIA _ IN. CLEARANCE__ IN VERTILATPUI'TS

PIT OR SUMP DEPTH 6

PUMP LENGTH.

MIN SUBMERGENCE REOD :

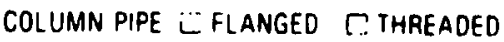

LINE SHAFT DI OPEN $[$ : ENCLOSED

BRGS DBOWL_CI LINE SHAFT

BRG LUB IJ WATEA - OIL $\square$ GREASE

FLOAT \& ROD OCS OSS $r$ BR? ONONE

FLOAT SWITCH --

PUMP THRUSI LB $::$ UP $\because \because$ DOWN

MOUNTING PLATE REO D こ. WEIGHTS ANO DIMENEIONS

APPROX WT PUMP 8 BASE _ _

MOTOR_ IH TURBINE_ 8

BASE PLATE DIMENSIONS

APPLCAELE SPECTFICANOTS

O API 610 UXANSI B731 B732

$\otimes$ PROJECI SPECIFIT,ATIONS

$+-$ 


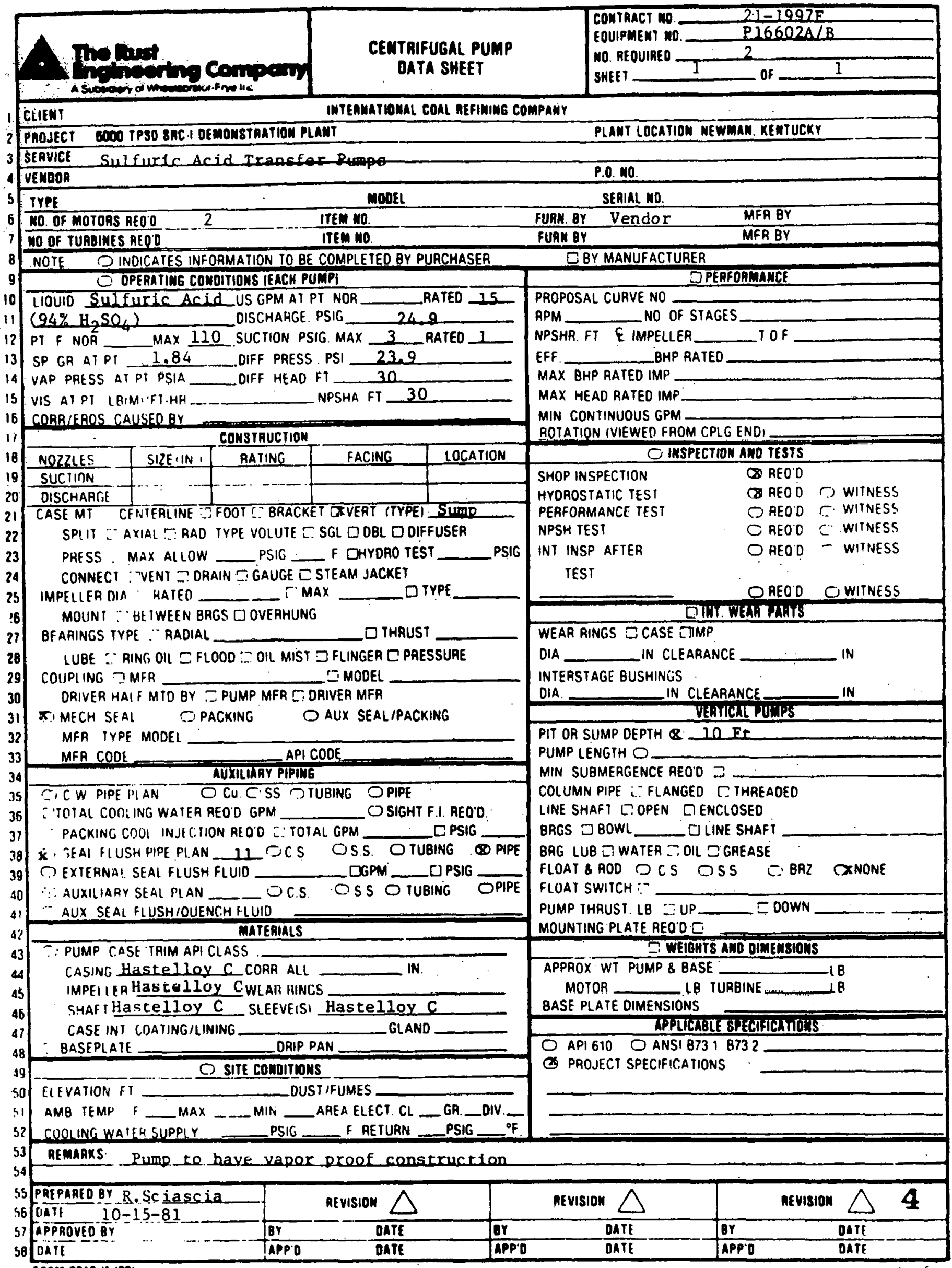




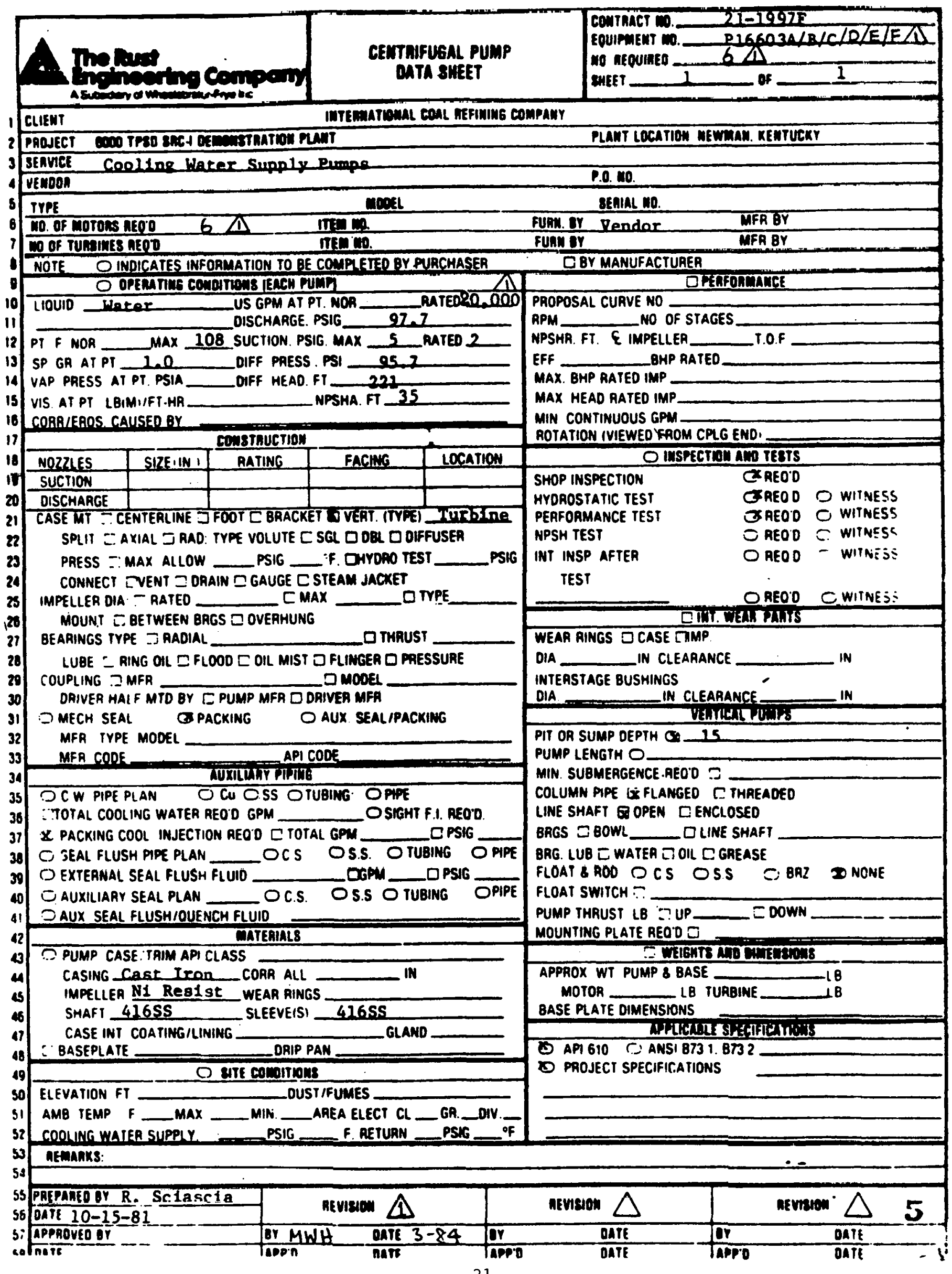




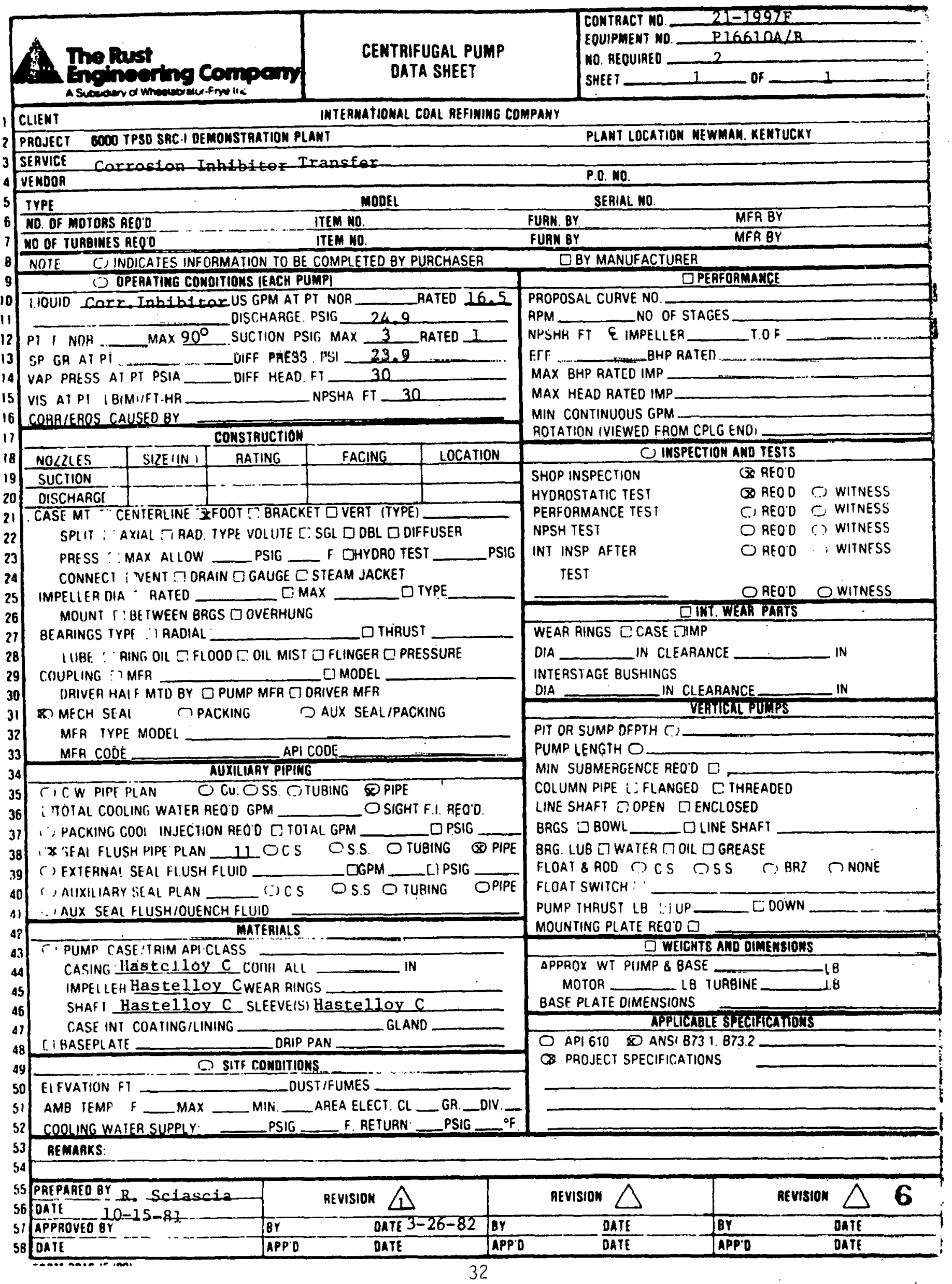




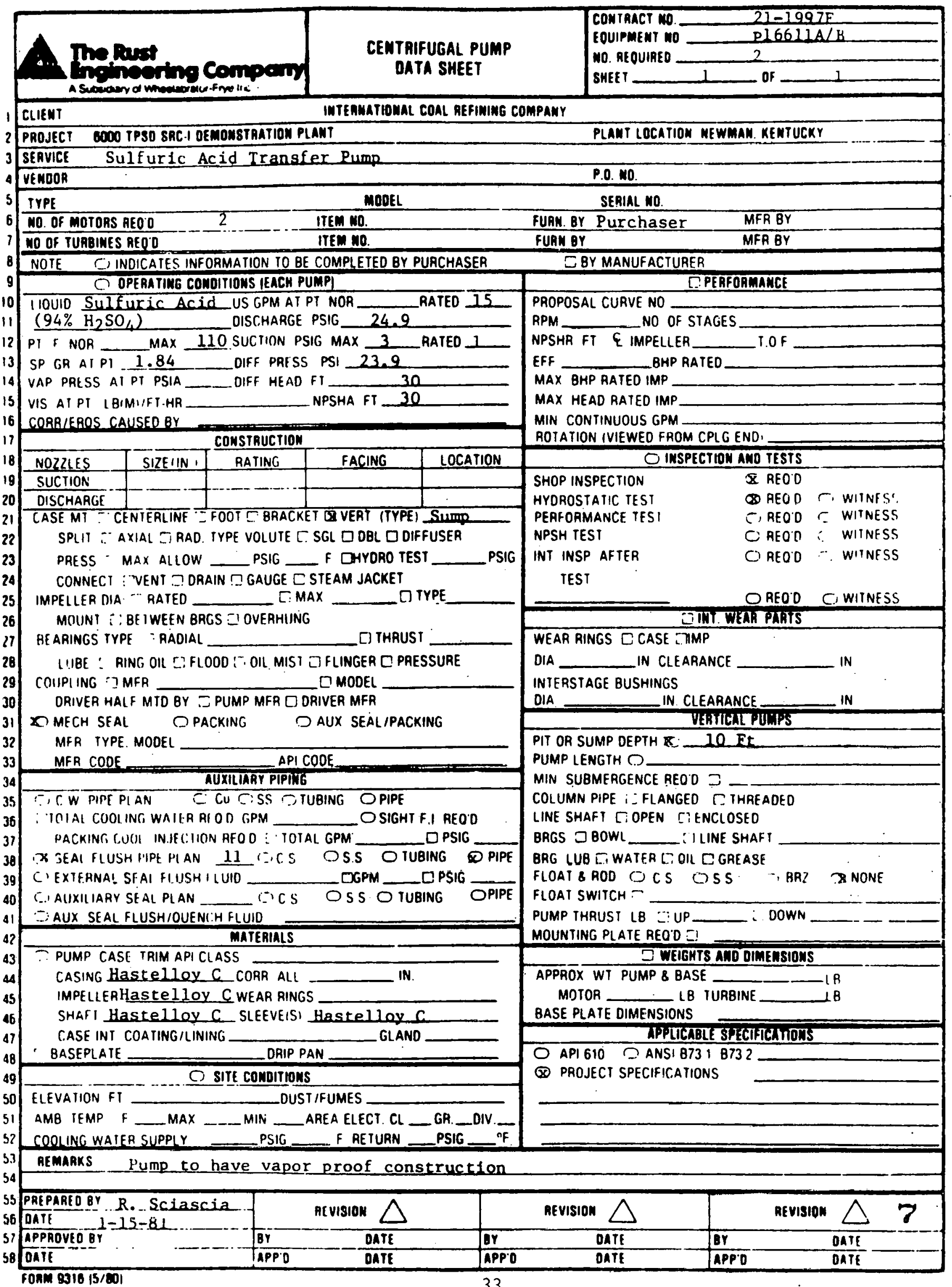




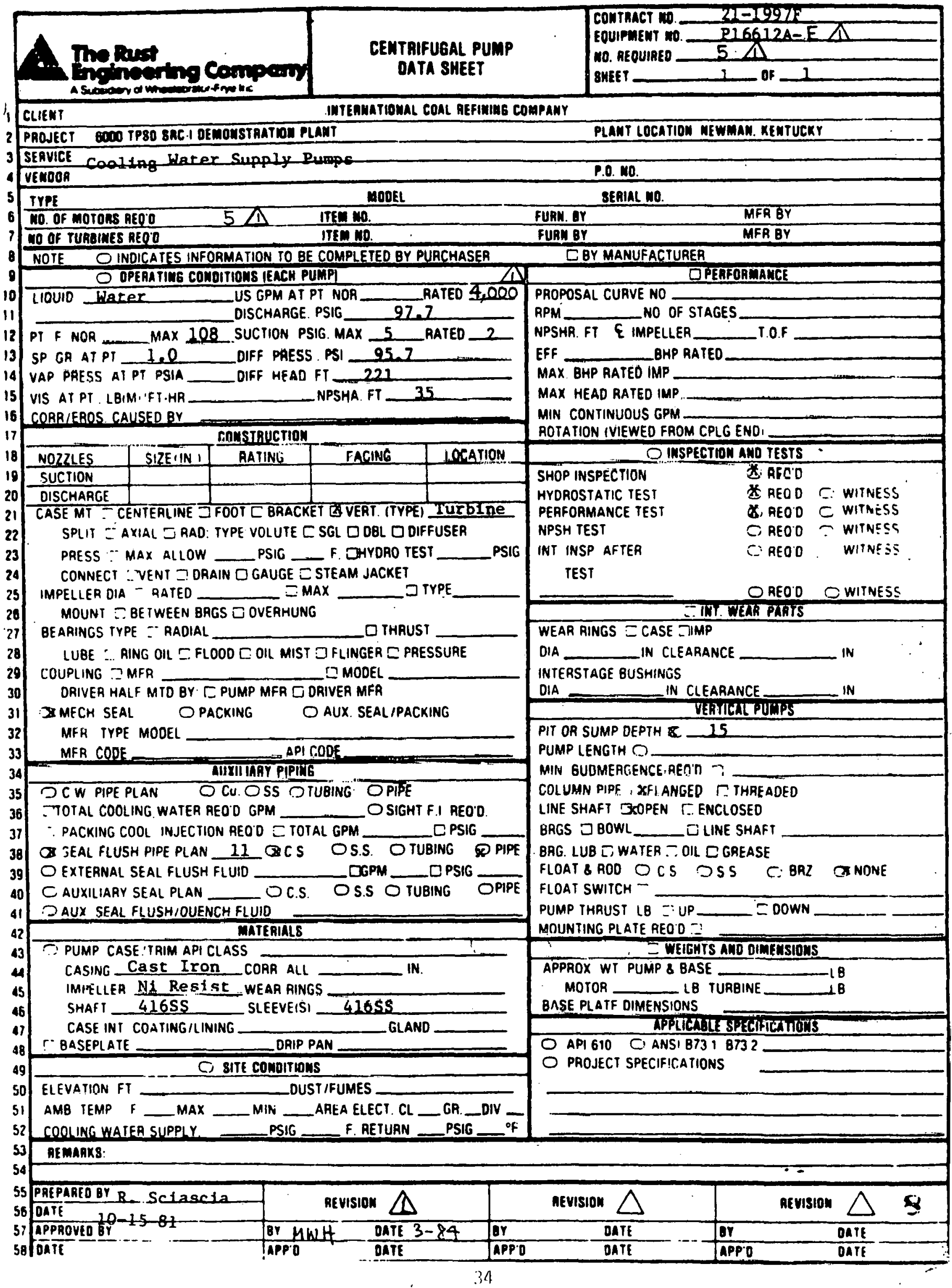




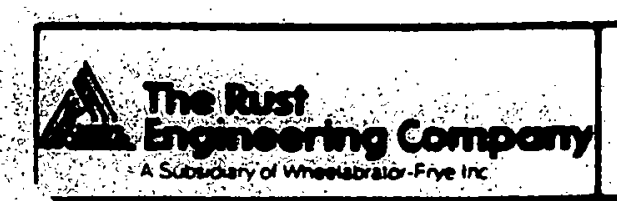

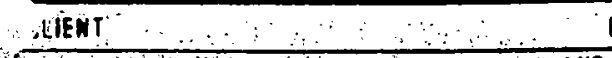

2 PROJECT GOOO TPSO SACI DEMONSTARAION PLANT

senvice Iuhibitua STuRnge.

A VUENOOOR

5 DIAME TER - 6 ' $\varnothing$

6 CAPACITY NORMAL

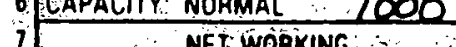

B OPEARTMG COMDITLNS

9 SPECIFIC GRAVITY LIO

10 PUMPING RATES IN

1. VAPOR PRESS

12 MAX OPER TEMP

13

$14 \mathrm{coD}$

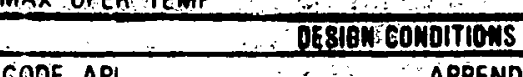

15 DESIGN METAL TEMP

16. DESIGN PAESS

17 CORROSION ALLOW SHELL

18

19

20 OYYPE Flar To

ROOF LIVE LOAOS

21 WINO PAESS

22 EARTHOUAKE COOE

23 FOUNOATION TYPE

24 RAODIOGRAPHY EXTENT

ZS ISTRESS RELIEF YVSINO

OUSULÁTION YES

EEAK TESTING BOTTOM

28 MILL TEST REPORTS YESINO

29 PAINING YESI SPEC ShC, COA

$3 i$

32

33

3

3

36

3

38

39

40

41

$4 ?$

43

44

45

46

48

1

5

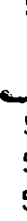

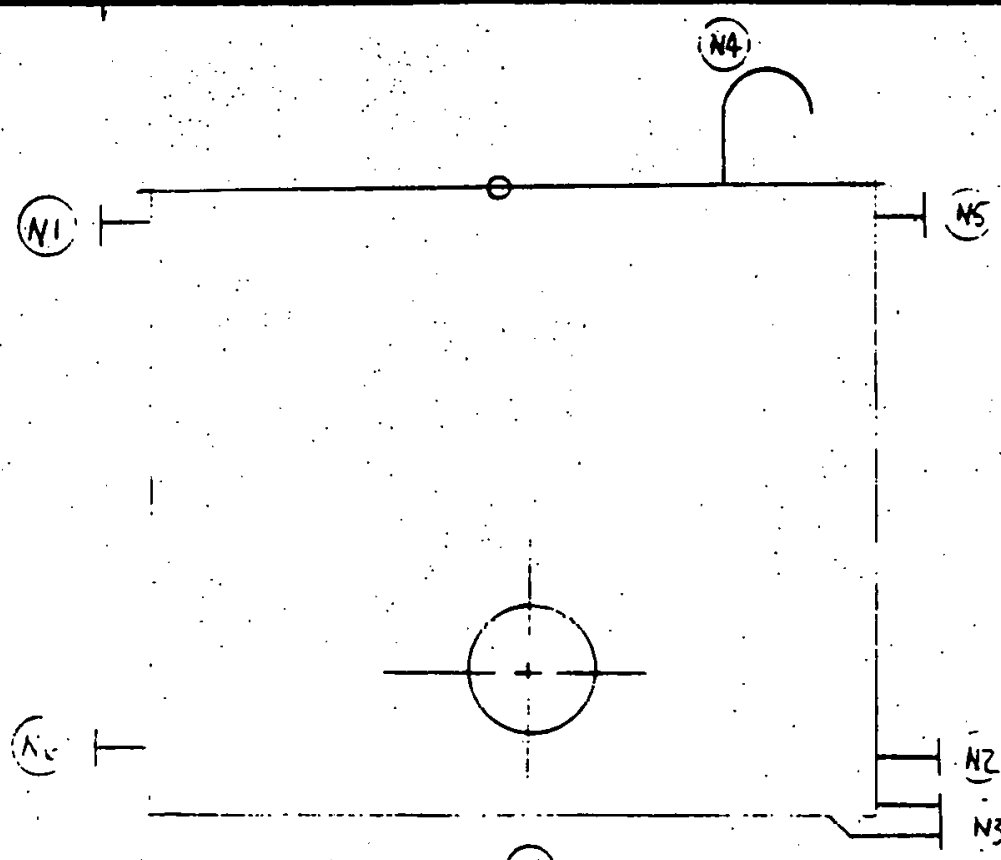

(41)

OF INTERNALS: FIXED

\begin{tabular}{|l|l|l}
\hline MARK & NO. & $812 E$
\end{tabular}
APPENDIX
STORAGE TAVIX

DATA SHEET contruct no: $21-19976$

EQuirment no. $\tau K-16(20)$

WO. AEQUIAEO

BHEET

of 1

interantional coAl aEFIMIME COMPAMY

PLAmt location newman: Re Mt UCKY

P.o. No.

FT. MATERIAL

GAL SHELL FRP THICK

GAL ROOF

of STRUCTURALS

GPM NOZZLE: NECK

THICK

THICK IN

OUT $\quad$ GPM NOZZL: NECK

FLANGE

GASKETS

of BOLTING

IN. WATER EST. ERECTION WT (LB)

IN. TozZLL's

\begin{tabular}{lll|l} 
ROOF & IN. \\
INTEANALS & IN. FLWEE RATHG
\end{tabular}

COUPLING RATTNC

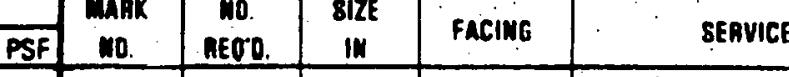

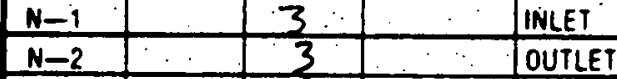

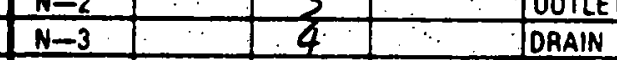

EXTEN

SHELL:

$M-5$

ROOF

$\frac{N-6}{N-7}$

$M-1$

\begin{tabular}{|c|c|}
\hline 2 & \\
\hline 3 & \\
\hline 3 & \\
\hline & \\
\hline & \\
\hline
\end{tabular}

RELIEF/VENT

INLET

Ontler

MAN WAY

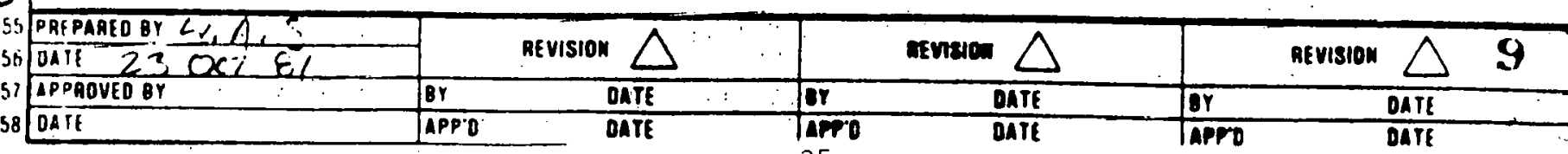




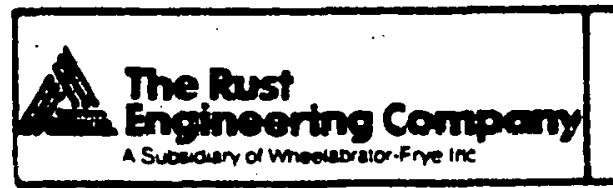

CLENT

2 PROJECT 6000 TPSO SRC.I DEMONSTRATION PLAKT

3 SERVICE

4 VENOOR

sulfuRIC ACID STORAgR

STORAGE TANK

DATA SHEET

INTERMATIOUAL COAL AEFIMIME COMPAMY

5 OIAMETER 12

6 CAPACITY NORMA

HEIGHT

$12^{\prime} T-T$

NET WOAKING

OPERATING CONDITIONS

SPECIFIC GRAVITY. LIO $1.835-4$ AT TEMP

- 10 PUMPING RATES: IN

11 VAPOR PAESS

12 MAX. OPER TEMP

13

14 COOE: AP

15 DESIGH METAL TEMP

16 DESIGN PRESS

17 CORROSION ALLOW: SHELL

18

19 ROOF TYPE HORIEOATAL

20 AOOF LIVE LOADS

21 WIND PRESS

22 EARTHOUAKE: COOE

23 FOUNDATION TYPE

24 RADIOGRAPHY EXTENT

25 STRESS RELIEF YESINO

'NSULATION: SNO

- LEAK TESTING BOTTOM

28 MILL TEST REPOATS YESINO

29 PAINTING YES SPEC SHCP COAT

30 SKETCH

- 31

32

- 33

3

. 36

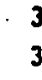

37

$\therefore 40$

4

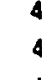

$$
45
$$

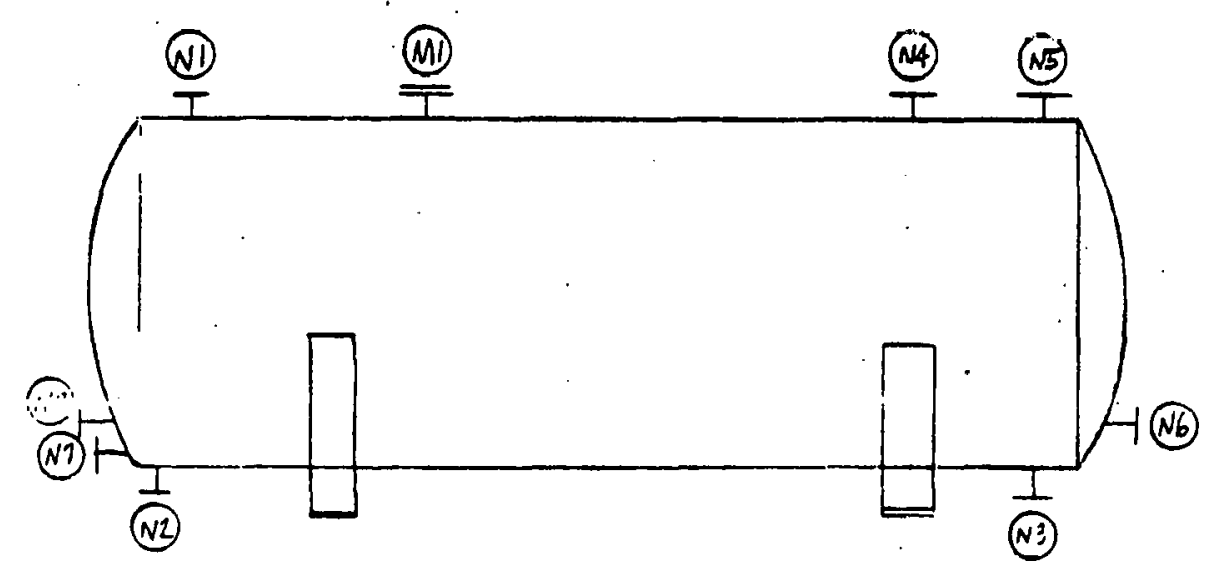

$$
\begin{aligned}
& 56 \\
& -3 \\
& 55 \\
& 56 \\
& 5 ! \\
& 58
\end{aligned}
$$

5 PREPAREO BY $\checkmark, A . S$.

56 DATE 2:20C7 81

51 APPROVEO BY

$5 8 \longdiv { \text { OATE } }$

\begin{tabular}{|l} 
REVISION \\
APPO D DATE
\end{tabular}

GPM NOZZLE: NEC

COUPLINGS

of INTERNALS: FIXED APPENOIX

RASKETS

OF BOLTING

IN.WATER EST. ERECTION WT (LB)

IN.

Tozilas

INTERNALS IN. FLAMBE ACTIII

PLANT LOCATION MEWMAN. KENTUCKY

P.0. 10

MATERIAL

THICK

THICK

THICK.

FLANGE REMOVABLE

mank

817 COUPLISALTING

PSF

$N_{N-2}^{N-1}$

\begin{tabular}{l|}
\hline-2 \\
\hline$N-3$ \\
\hline$N-4$ \\
\hline$N-5$ \\
\hline$N-6$ \\
\hline$N-7$ \\
\hline$M-1$ \\
\hline
\end{tabular}

\begin{tabular}{c|c} 
NOO. & 81 \\
nEPO & II \\
\hline & 2
\end{tabular}

\begin{tabular}{c|c|}
\hline In & Facimg \\
\hline 2 & \\
\hline
\end{tabular}

\begin{tabular}{|l|l|l|}
\hline 2 & & OUTLET \\
\hline
\end{tabular}

\begin{tabular}{|c}
$\frac{4}{2}$ \\
$\frac{1}{2}$ \\
\hline 2
\end{tabular}

$\mid$\begin{tabular}{l|}
2 \\
\hline$A$ \\
$N A$
\end{tabular}

\begin{tabular}{l|l} 
NA & MAN WAY \\
\hline
\end{tabular} seavice 


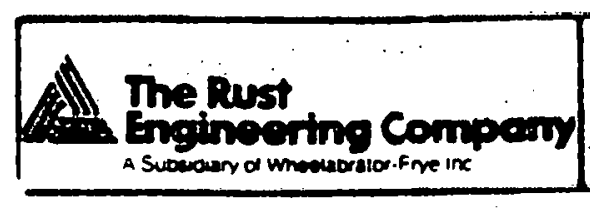

STORAGE TANK
DATA SHEET

COMTAACT MO 2U1-19GFE

EOUIPMENT NO. TK-16610

MO. REOUIREO

SHEET

of 1

CLIENT.

IMTERMATIOMAL COAL REFIMIMG COMPAMY

2 PROSECT 6000 TPSO SAC.I OEMONSTRATIOM PUANT

PLAMT LOCATION MEWMAK. KEMTUCKY

3 SERVICE INbibitur STORAgS

5 DIAMETER $6^{\prime} \quad$ HEIGHT 4.5

6 CAPACITY NORMAL 1000

7 NET WOAKING

OPERATIMG COMOITIONS

8 SPECIFIC GRAVITY. LIO

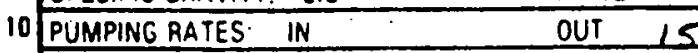

AT TEMP

P.O. MO.

11 VAPOR PRESS

GPM NOZZLE: NECK

IN WATER COUPLINGS

$1 2 \longdiv { M A X . O P E R }$ TEMP $90^{\circ} \mathrm{F}$

13

3

CODE. API

DEBIGM COHOITIONS

5 DESIGN METAL TEMP

APPENOIX

OF INTERNALS: FIXED

16 DESIGN PRESS

17 CORROSION ALLOW. SHELL

18

19 ROOF TYPE

20 ROOF LIVE LOADS

21 WINO PRESS

22 EARTHQUAKE CODE

23 FOUNDATION TYPE

24 RADIOGRAPHY. EXTENT

75 STRESS RELLEF: YES/NO

$\because$ INSULATION YES/

$\because$ LEAK TESTING BOTTOM BOTTOM

\begin{tabular}{l|l} 
FT. & \\
GAL & SHELL
\end{tabular} MATERIAL

GAL ROOF

BOTTOM

THICK:

THICK.

THICK.

28 MILL TEST AEPORTS YES/NO

29 PAINTING YESN SPEC Shea Coa

$3 0 \longdiv { \text { SKETCH } }$

3

32

33

3

35

36

37

38

40

42

4

4

45

4

48
49
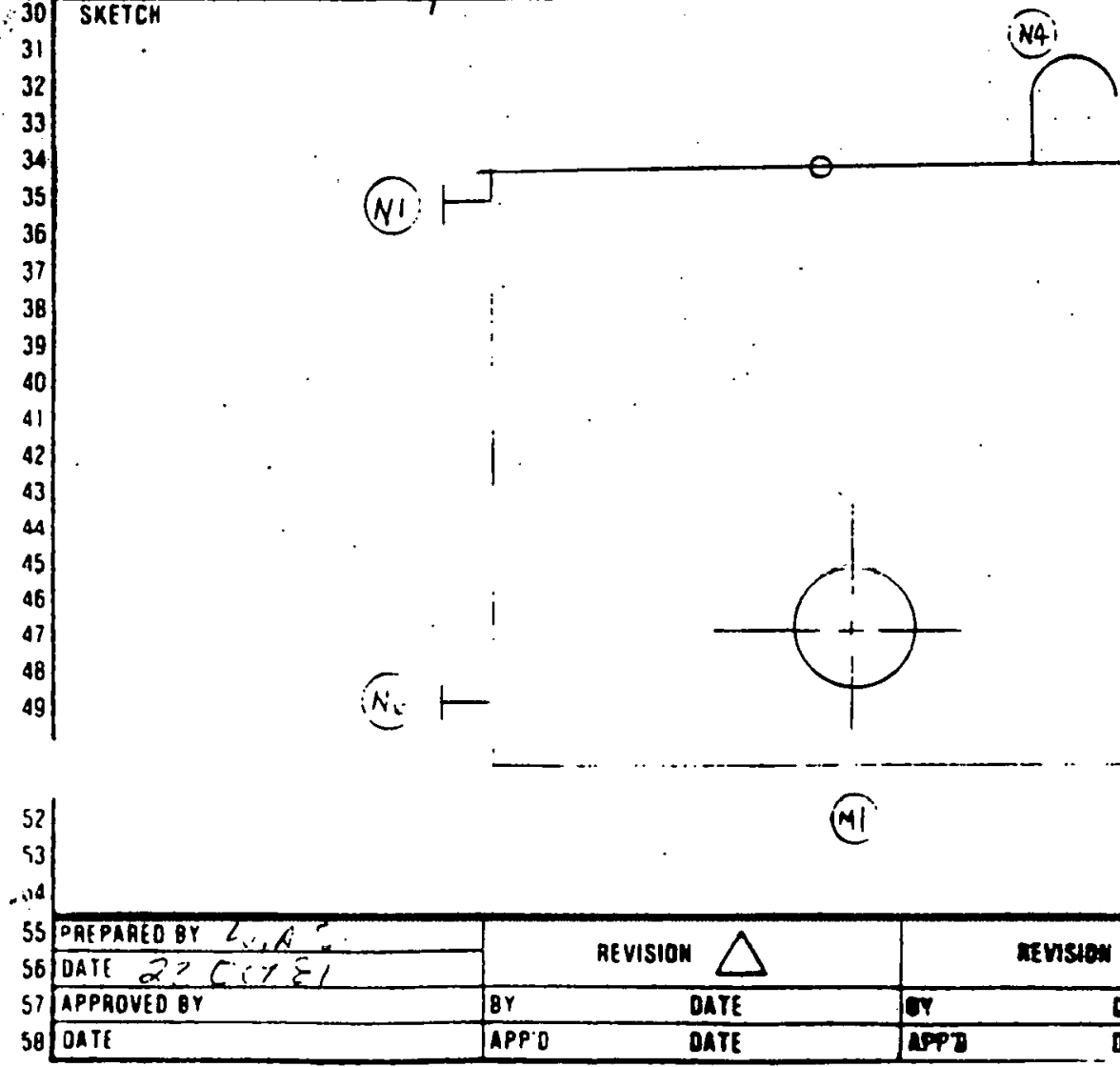

GASKETS

OF BOLTING

IN WATER EST. ERECTION WT LLB

IN.

TÜZILES

INTERNALS IN. FLAMGE RATIMG COUPLIMG RATING

I. Henges
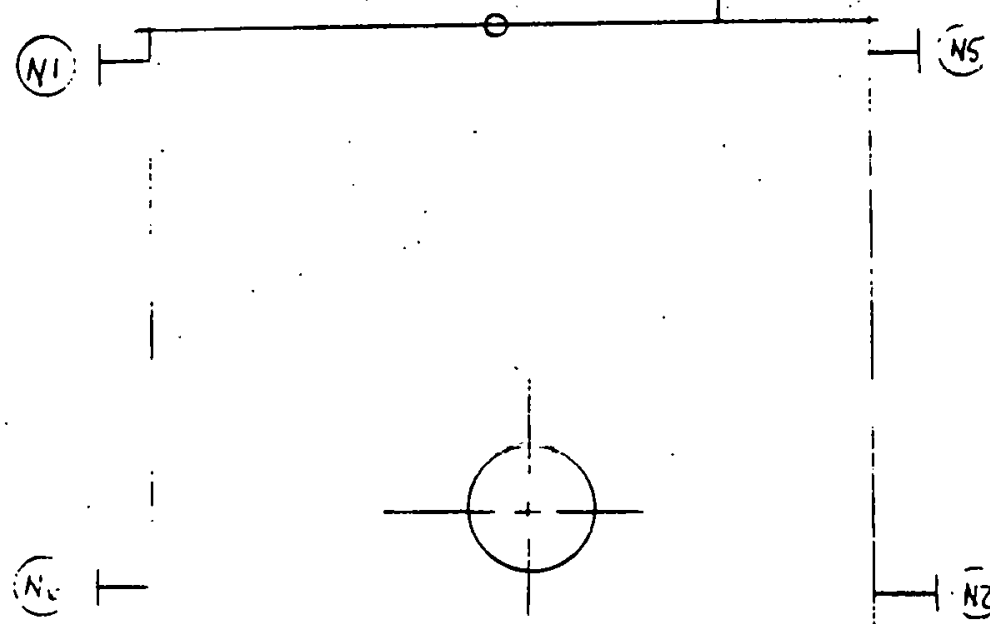

FLANGE

REMOVABLE

\begin{tabular}{c|c|c|c|}
\hline PSF NO. & REOD. & SIZE & FACING \\
\hline
\end{tabular}

III

SEAvice

ZONE 


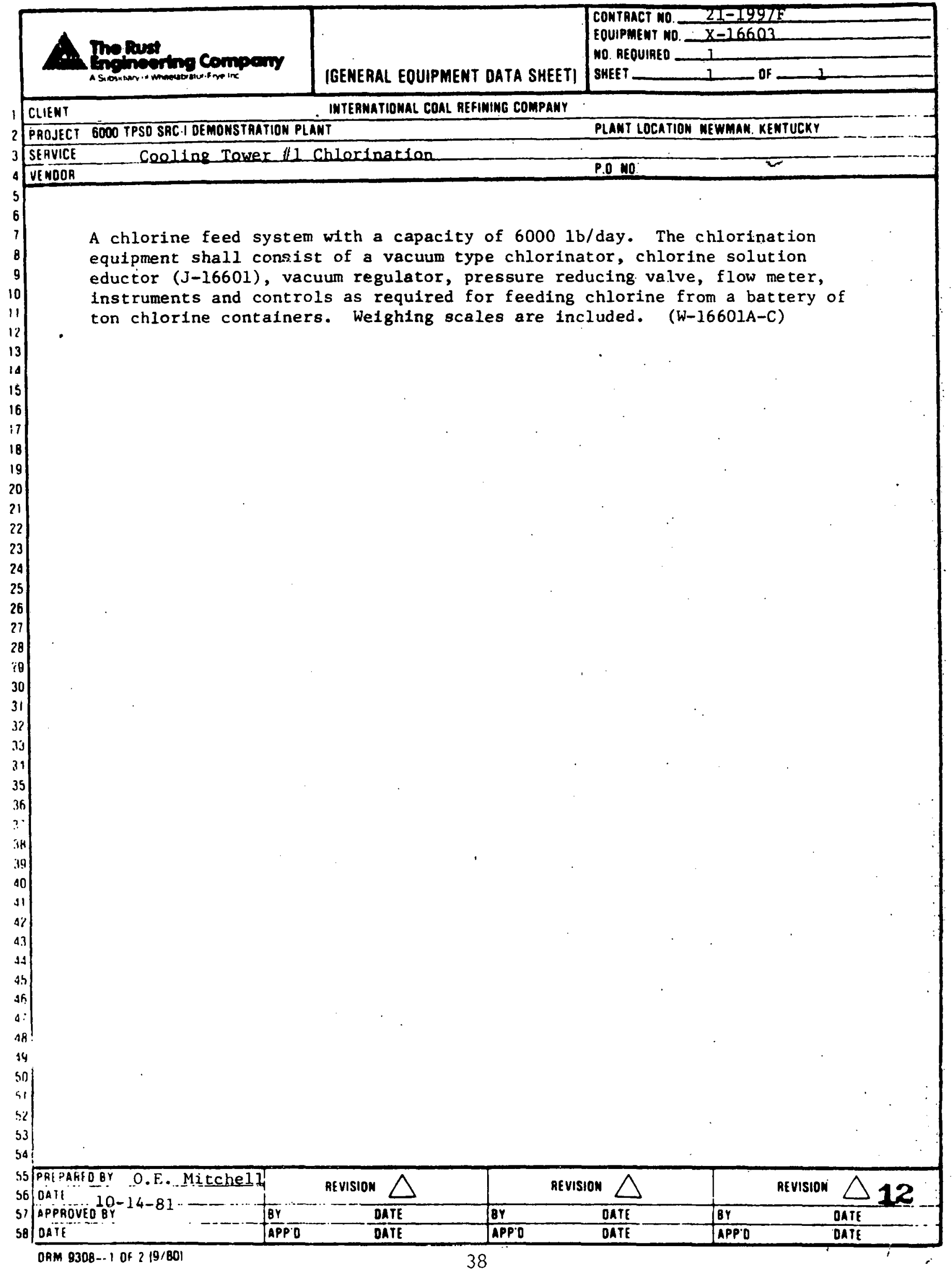




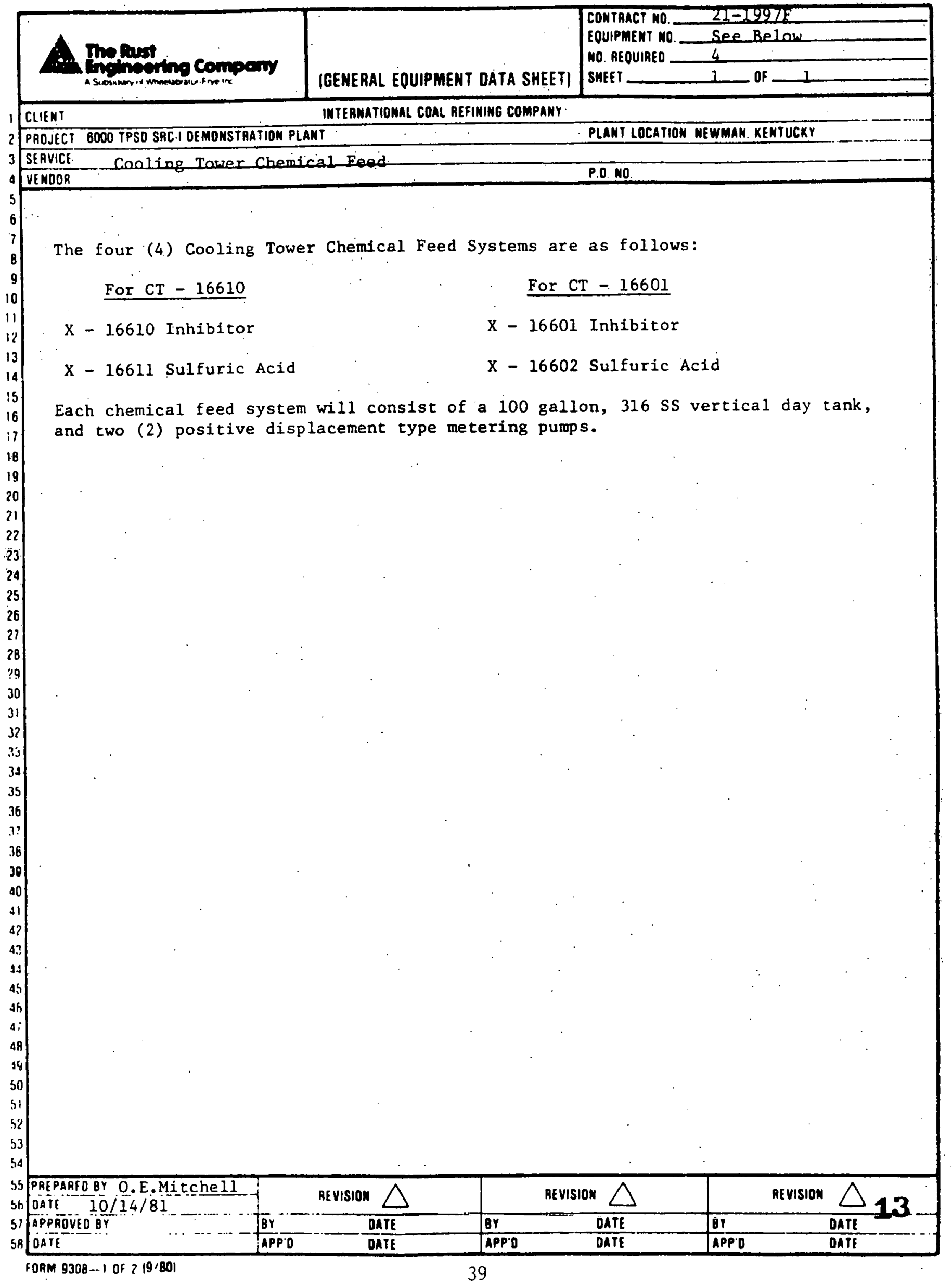




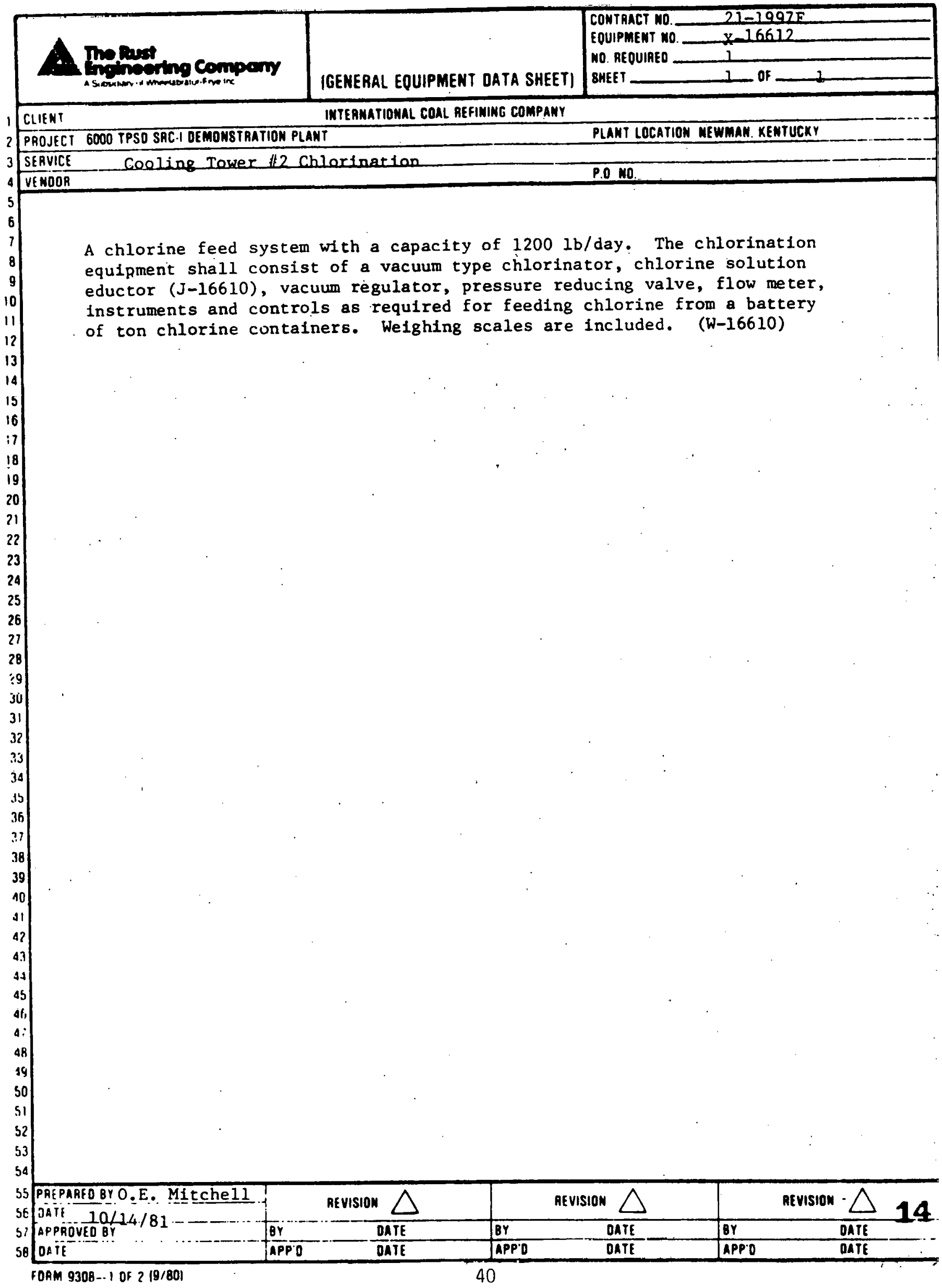




\section{2 .5 Process Water Supply}

\subsubsection{System Description}

A combination process water and fire water storage tank constructed of carbon steel will be provided. Only the upper portion of the tank, $1,600,000$ gallons, will be available for process water storage. The entire tank, 3.6 million gallons, will be available for fire water storage. The process water pumps (P-17108 A-C) operating on pressure control, will provide a constant supply to the process water distribution header.

\subsubsection{Utility Flow Diagram}

Refer to the following drawing included with Process Water Treatment, Paragraph 3.1.2.

00-17-01003D Process water Treatment Process and Control Diagram (Sheet 2) 


\subsubsection{Potable Water Supply}

\subsubsection{System Description}

A water storage tank constructed of carbon steel will provide storage for potable water. A potable water booster pump ( $P-17203$ ) will be provided to maintain a constant pressure on the potable water distribution system. When the pressure in the distribution system drops, indicating an increase in demand, the potable water supply pumps ( $P-17204 A$ and $B$ ) will provide the increased flow requirement. Chlorine and sodium hexametaphosphate will be added to maintain a residual concentration of each in the distribution header. The chlorinator $(X-17202)$ and the sodium hexametaphosphate feed system $(X-17201)$ are further described in paragraph 3.1.1, Potable Water Treatment.

\subsubsection{Utility Flow Diagram}

Reter to the tollowing drawing included with Potable Water I reatment, Paragraph 3.1.1.

00-17-01001D Potable Water System Process and Control Diagram 


\subsubsection{Nitrogen System}

\subsubsection{System Description}

The nitrogen system consists of piping, valves, and flowmeters necessary to distribute nitrogen from the area 14 afr separator unit to the vartous area contractors. All of the nitrogen producing equipment is furnished by the area 14 contractor.

\subsubsection{Ut1lity Flow Diagram}

Refer to the following drawing included with Interconnecting Systems, Paragraph 2.3.

00-16-03009 Interconnecting Piping System, Nitrogen 


\subsubsection{Compressed Air System (Refer to Process Flow Diagram}

No. 00-16-01004D and Interconnecting Piping System. instrument Air/Plant Air. Dwg. No. 00-16-03008)

\subsubsection{System Description}

\subsection{General}

The plant and instrument air requirements are provided by common compressed air system, including a common distribution header. Pressure control valves are furnished for the plant air lines at the battery limits of each area contractor air user to prevent depressurization of the compressed air system. Since a common system is provided, both plant and instrument air are of the same quality at the area contractors battery limits. The system consists of three centrifugal air compressors, three prefilters, one air dryer, three afterfilters, one receiver vessel, distribution piping, and valves.

\subsection{Air Compressors}

Two of three motor-driven, packaged centrifugal air compressors (C-16701 $A, B$, and C) are provided to meet the normal instrument and plant air requirements. All three compressors are needed to satisfy the maximum air demand. Each air compressor has four stages of compression and includes air intake filter, three intercoolers, one aftercooler with moisture separator, inlet throttle valve, discharge check valve, bypass silencer, control panel, and lubrication system. The lubrication system provides sufficient lubrication to the compressor bearings for rontinuous operation, start-up, and emergency loss of power conditions.

\subsection{Prefilters}

Following the compressors, the compressed air enters the coalescing, cartridge type prefilters (FL-16702 A, B, and C) for removal of any entrained 
moisture or oil. Two of the prefilters are adequate to meet maximum plant and instrument air demands.

\subsection{Air Dryer}

After the prefilters, the compressed air passes through a desiccant type, heat regenerated, twin tower air dryer (D-16701) for dew point suppression to $-40^{\circ} \mathrm{F}$ at 100 psig pressure. One air dryer is furnished and is sized for maximum plant and instrument air demand.

\subsection{Afterfilters}

Three cartridge-type afterfilters (FL-16703A, B and C) are furnished on the outlet of the aryer to remove dust or desiccant carryover from the dryer. Two of the afterfilters are adequate to meet the maximum plant and instrument air demand.

\subsection{Air Receiver}

One common air receiver $(V-16701)$ vessel is furnished for the compressed air system and is sized for the maximum air demand conditions. The receiver is a vertical, cylindrical pressure vessel designed and fabricated in accordance with the ASME Boiler and Pressure Vessel Code.

\subsubsection{Utility Flow Diagram}

The following utility flow diagram is included after this page:

$$
\text { 00-16-01004D Compressed Air System Process Flow Diagram }
$$




\subsubsection{Utility Summary}

The utility sumary for the Compressed Air System follows this page. 


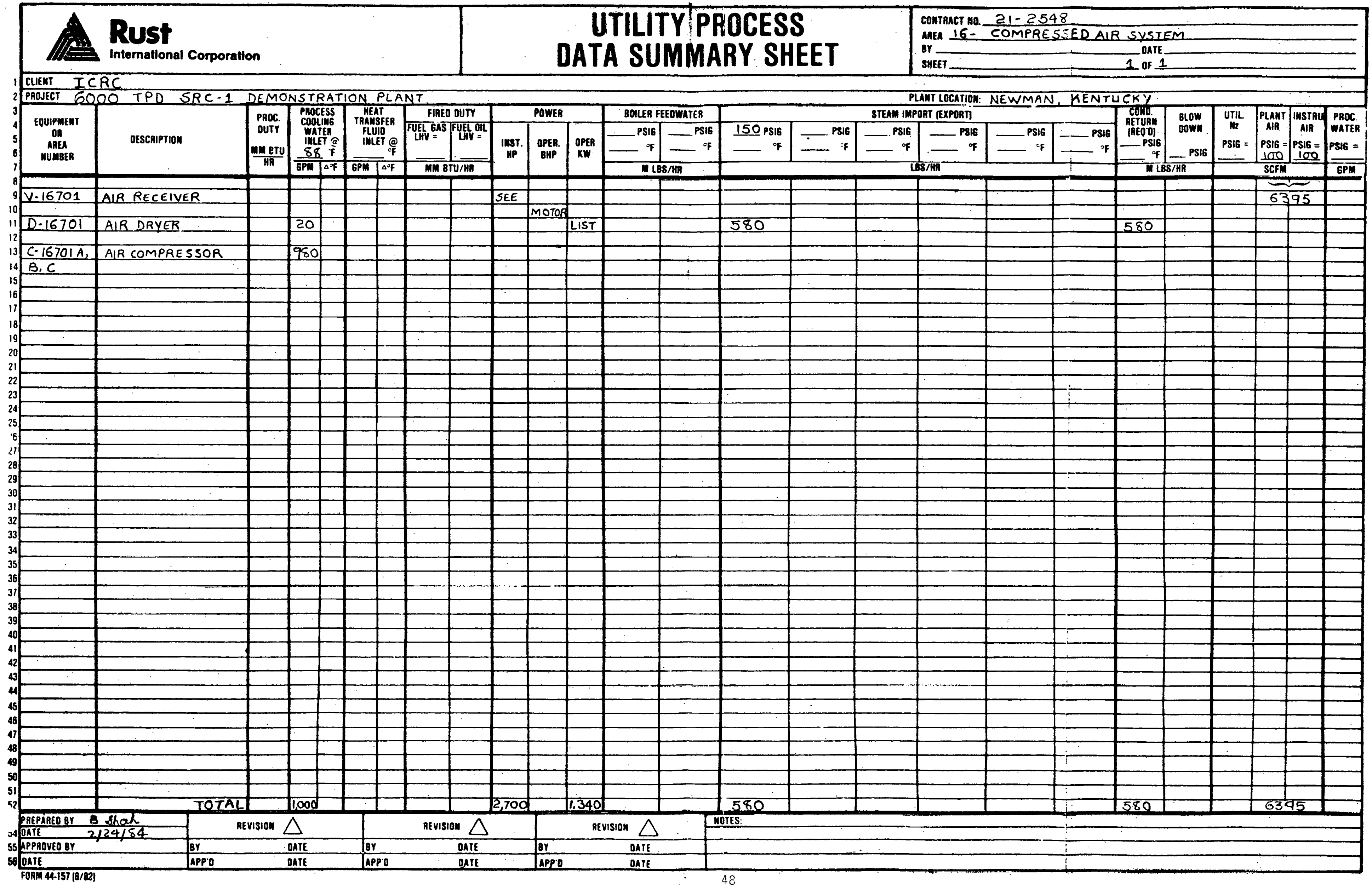




\subsubsection{Motor List}

The motor list for the Compressed Air System follows this page. 


\section{COMPRESSED AIR SYSTEM}

MOTOR LIST

Equipment No.

$C-16701 A$
$C-16701 B$
$C-16701 C$
Description

A1r Compressor

Air Compressor

Air Compressor

TOTAL

\begin{tabular}{|c|c|c|c|}
\hline $\begin{array}{c}\text { Installed } \\
\mathrm{Hp}_{\mathrm{p}} \\
\end{array}$ & $\begin{array}{l}\text { Operating } \\
\mathrm{KW} \\
\end{array}$ & $\begin{array}{l}\text { HR/ } \\
\text { Day }\end{array}$ & $\begin{array}{l}\text { KIVH/ } \\
\text { DAY }\end{array}$ \\
\hline 900 & 670 & 24 & 16,080 \\
\hline 900 & 670 & 24 & 16,080 \\
\hline 900 & 0 & 0 & . \\
\hline
\end{tabular}

$2,700 \quad 1,340$

32,160 


\subsubsection{Equipment List/Summary}

The equipment list/summary for the compressed air system follows this page. 
WBS ELEKENT: 1.4 .1 .1 .2 ICRC AREA: 16

\begin{tabular}{|c|c|c|c|c|c|c|c|c|c|c|c|c|c|c|c|}
\hline \multirow{3}{*}{ REV. } & \multirow{3}{*}{$\begin{array}{l}\text { ICRC/RUST } \\
\text { EQUIP NO } \\
\text { C-16701 } \\
\text { A thru C }\end{array}$} & \multirow{3}{*}{ QTY } & \multirow{3}{*}{ 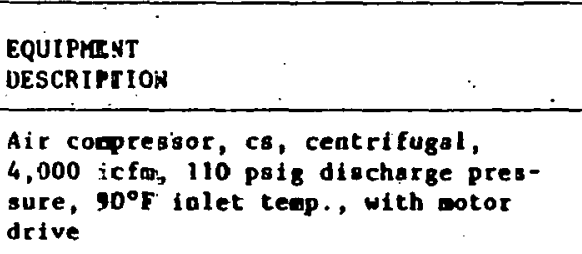 } & \multirow{3}{*}{$\begin{array}{l}\text { P.O. } \\
\text { HAMBER } \\
\end{array}$} & \multirow{3}{*}{$\begin{array}{l}\text { SIZE/ } \\
\text { WEIGHT } \\
900 \mathrm{hp} \\
1,800 \mathrm{rpm}\end{array}$} & \multirow{2}{*}{\multicolumn{2}{|c|}{$\begin{array}{l}\text { P.o. } \\
\text { DATE }\end{array}$}} & \multirow{2}{*}{\multicolumn{3}{|c|}{$\begin{array}{l}\text { VENDOR EEG } \\
\text { NEED COST } \\
\text { DATE }\end{array}$}} & \multirow{2}{*}{\multicolumn{2}{|c|}{$\begin{array}{l}\text { DELV } \\
\text { DATE }\end{array}$}} & \multirow{3}{*}{$\begin{array}{l}\begin{array}{l}\text { EQUIP } \\
\text { COST }\end{array} \\
138.4 \mathrm{ea}\end{array}$} & \multirow{3}{*}{$\begin{array}{l}\begin{array}{c}\text { PURCH } \\
\text { BY }\end{array} \\
\text { RUST }\end{array}$} & \multirow{3}{*}{$\begin{array}{l}\begin{array}{l}\text { TYPE } \\
\text { EQUIP }\end{array} \\
\text { SF }\end{array}$} \\
\hline & & & & & & & & & & & & & & & \\
\hline & & & & & & $\begin{array}{l}S \\
p \\
A\end{array}$ & $10-82$ & $\begin{array}{l}\text { S } \\
\text { P } \\
\text { A }\end{array}$ & $1-83$ & $14.9 \mathrm{es}$ & $\begin{array}{l}\mathbf{S} \\
\mathbf{P} \\
\mathbf{A}\end{array}$ & $6-83$ & & & \\
\hline 4 & $\begin{array}{l}D-16701 \\
A \text { and } B\end{array}$ & 2 & $\begin{array}{l}\text { Air dryer, desiccant type, } 8 \text { be., } \\
\text { NEMA cyele, } 150 \text { pois deaign, } \\
10,000 \text { scfi, } 150 \text { pols stess bester. } \\
-40^{\circ} \text { F eutlet dew point }\end{array}$ & & & $\begin{array}{l}\text { S } \\
\text { P } \\
A\end{array}$ & $10-82$ & $\begin{array}{l}s \\
\mathbf{p} \\
\mathbf{A}\end{array}$ & $1-83$ & $4.3 \mathrm{es}$ & $\begin{array}{l}\mathbf{S} \\
\mathbf{P} \\
\mathbf{A}\end{array}$ & $9-83$ & $82.7 \mathrm{ea}$ & RUST & SF \\
\hline \multirow[t]{4}{*}{2} & $\begin{array}{l}\text { FL- } 16701 \\
\text { A thru C }\end{array}$ & 3 & $\begin{array}{l}\text { Filter, air intake, cs, } 4000 \text { acfo, } \\
0 \text { pois, } 90^{\circ} \mathrm{F}, 118 \mathrm{sg} \text { ft effective } \\
\text { filter area }\end{array}$ & & & $\begin{array}{l}\text { s } \\
\text { P } \\
\text { A }\end{array}$ & $10-82$ & $\begin{array}{l}\mathbf{S} \\
\mathbf{P} \\
\mathbf{A}\end{array}$ & $1-83$ & $1.0 \mathrm{ea}$ & $\begin{array}{l}\mathbf{s} \\
\mathbf{p} \\
\mathbf{A}\end{array}$ & $6-83$ & $7.8 \mathrm{ea}$ & RUST & $\mathbf{s F}$ \\
\hline & $\begin{array}{l}\text { FL- } 16702 \\
A \text { and B }\end{array}$ & 2 & $\begin{array}{l}\text { Air prefilter, coalesciog elements, } \\
5,000 \text { sct } 150 \text { po18 design, } 100 \text { pa } 18 \\
\text { operating, } 90^{\circ} \mathrm{F}, 214.2 \text { sq ft effective } \\
\text { filter area, 8" flange outlet }\end{array}$ & & & $\begin{array}{l}S \\
P \\
A\end{array}$ & $10-82$ & $\begin{array}{l}S \\
P \\
A\end{array}$ & $1-83$ & $\begin{array}{l}\text { inc } \\
\text { pith } \\
\text { rL-16701 }\end{array}$ & $\begin{array}{l}\text { S } \\
\text { P } \\
\text { A }\end{array}$ & $6-83$ & $\begin{array}{l}\text { inc } \\
\text { with } \\
\text { FL-16701 }\end{array}$ & RUST & SF \\
\hline & $\begin{array}{l}\text { FL }-16703 \\
A \text { and } B\end{array}$ & 2 & $\begin{array}{l}\text { Air prefilter, particulate elements, } \\
5,000 \mathrm{scf}, 150 \text { psig design, } 100 \text { psig } \\
\text { operat } \operatorname{lng}, 90^{\circ} \mathrm{F}, 214.2 \text { sq ft effec:ive } \\
\text { filter area, } 8^{\prime \prime} \text { flange out let }\end{array}$ & & & $\begin{array}{l}\text { S } \\
\text { P } \\
\mathbf{A}\end{array}$ & $10-82$ & $\begin{array}{l}\mathbf{s} \\
\mathbf{p} \\
\mathbf{A}\end{array}$ & $1-83$ & $\begin{array}{l}\text { :nc } \\
\text { uith } \\
\text { re-16701 }\end{array}$ & $\begin{array}{l}\text { S } \\
\mathbf{P} \\
\mathbf{A}\end{array}$ & $6-83$ & $\begin{array}{l}\text { inc } \\
\text { with } \\
\text { fL-16701 }\end{array}$ & RUST & $\mathbf{S F}$ \\
\hline & $v-16701$ & 1 & $\begin{array}{l}\text { Alr receiver, vertical, c8, } 150 \text { paig } \\
\text { design, ASHE vIll-1, 5,565 gal } \\
\text { capacity }\end{array}$ & & $\begin{array}{l}7 \text { dia } x \\
20^{\circ} \text { bigh }\end{array}$ & $\begin{array}{l}\text { S } \\
\text { P } \\
\text { A }\end{array}$ & $10-82$ & $\begin{array}{l}\text { S } \\
\text { P } \\
\text { A }\end{array}$ & $11-82$ & 2.1 & $\begin{array}{l}\text { S } \\
\mathbf{P} \\
\mathbf{A}\end{array}$ & $2-83$ & 17.7 & RUST & $\mathbf{S F}$ \\
\hline
\end{tabular}

\section{MOTES:}

1. All coses lat Querter Fiscal Year 1982 in thousand dollors.

2. Equipment costs are FOB jobsite with shipping 8 vendor field

NuST: Rust Eagineering support less vendor engineering.
3. This equipment is Apperdiz C Bulks.
3.
S: Scheduled

P: Projected

A: Actual
rL: Field Labor H/A: Not Applicable

H: Material for field fab equipent

SF: Shop Fabricated FT: Field Fabricaled 


\subsubsection{Equipment Data Sheets}

The equipment data sheets for the compressed air system follow this page. 


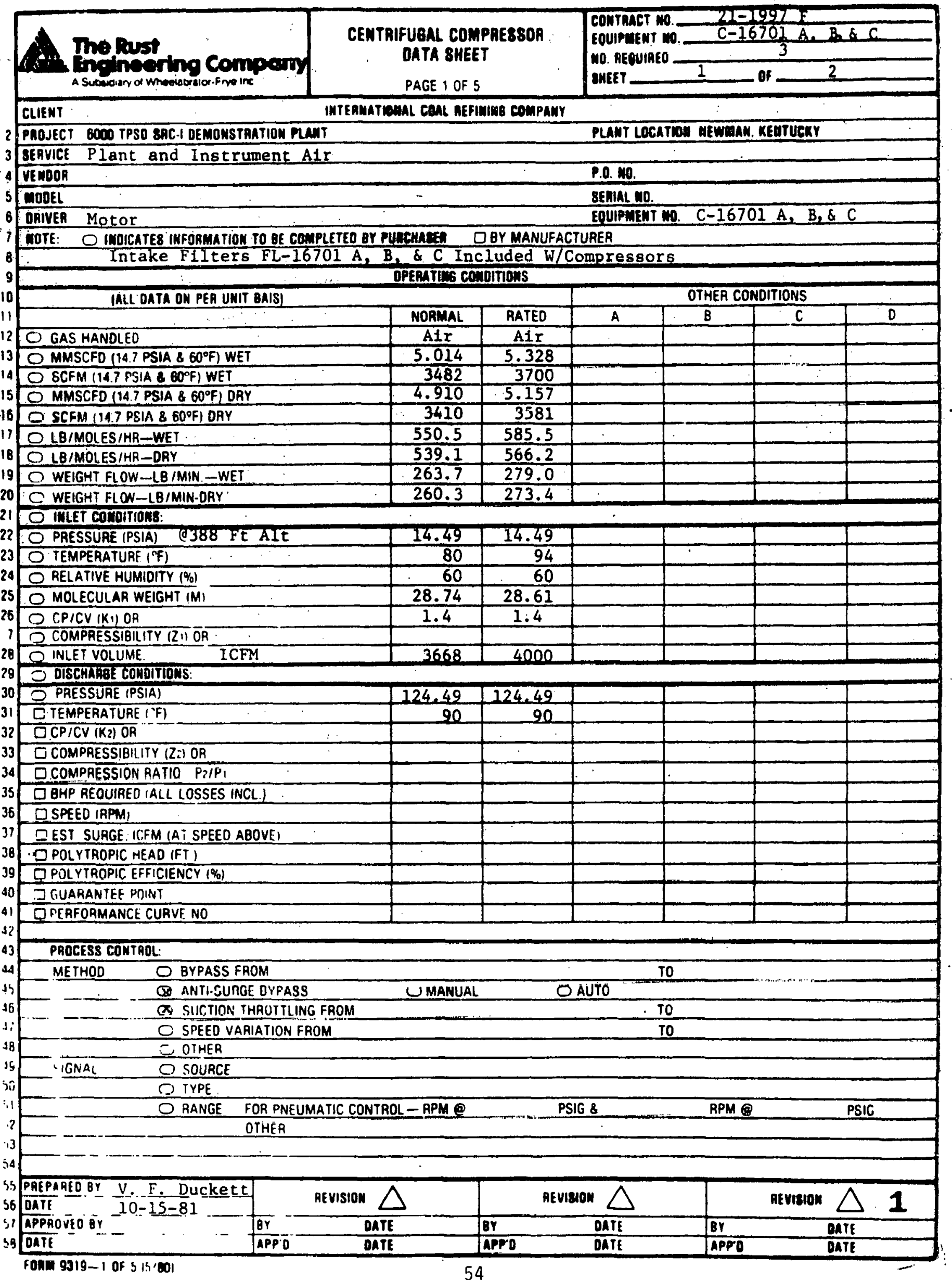




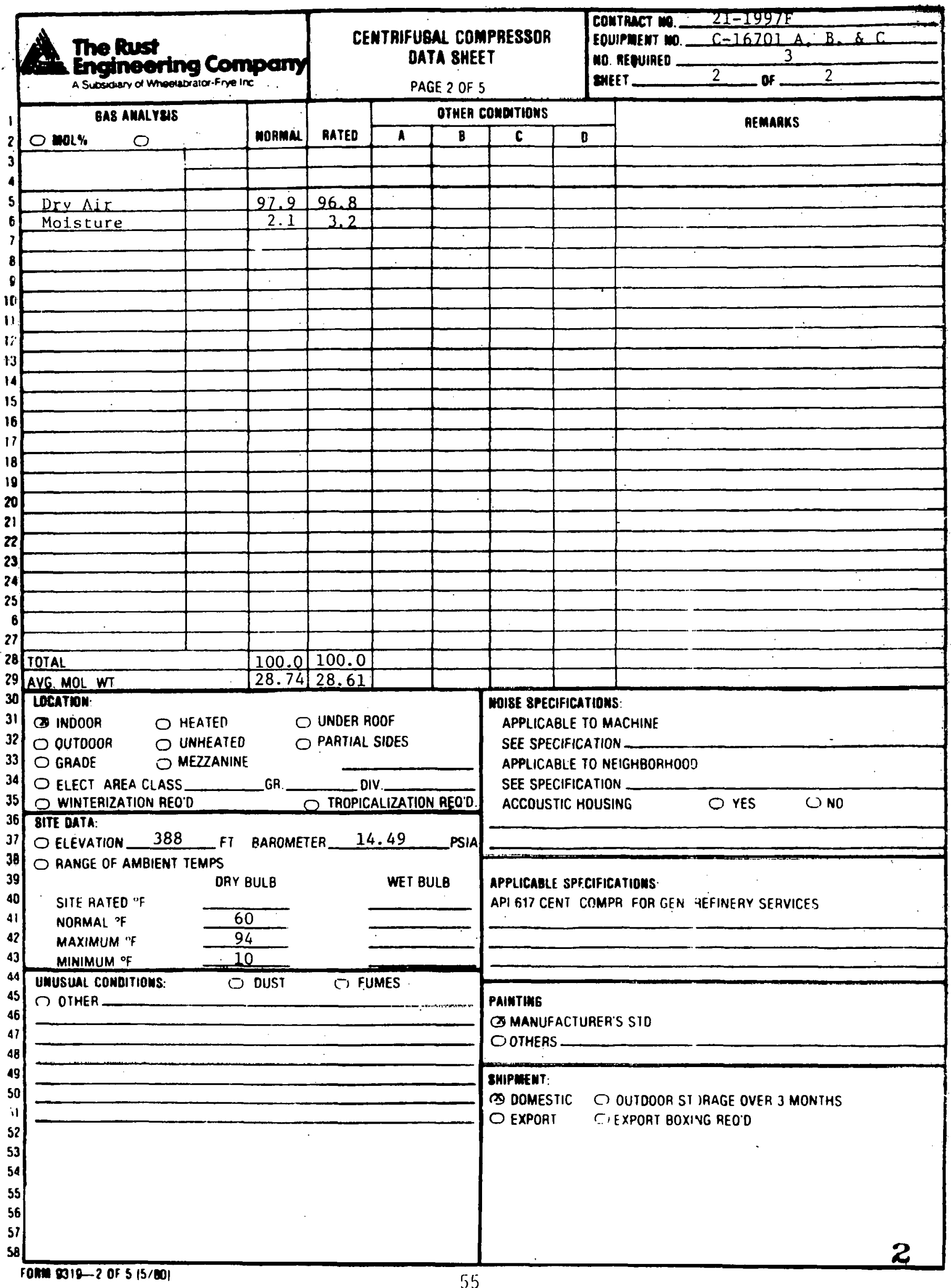




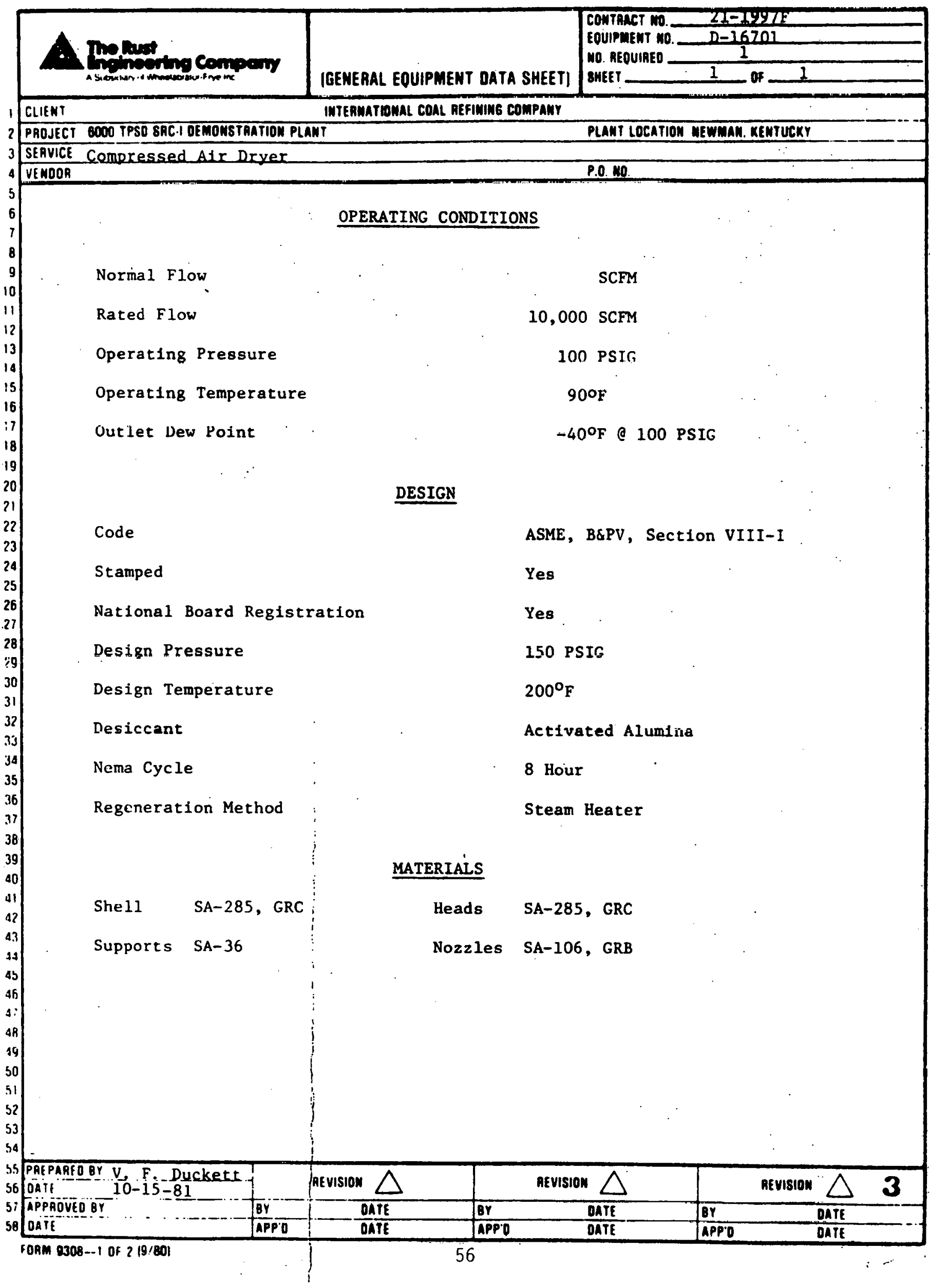




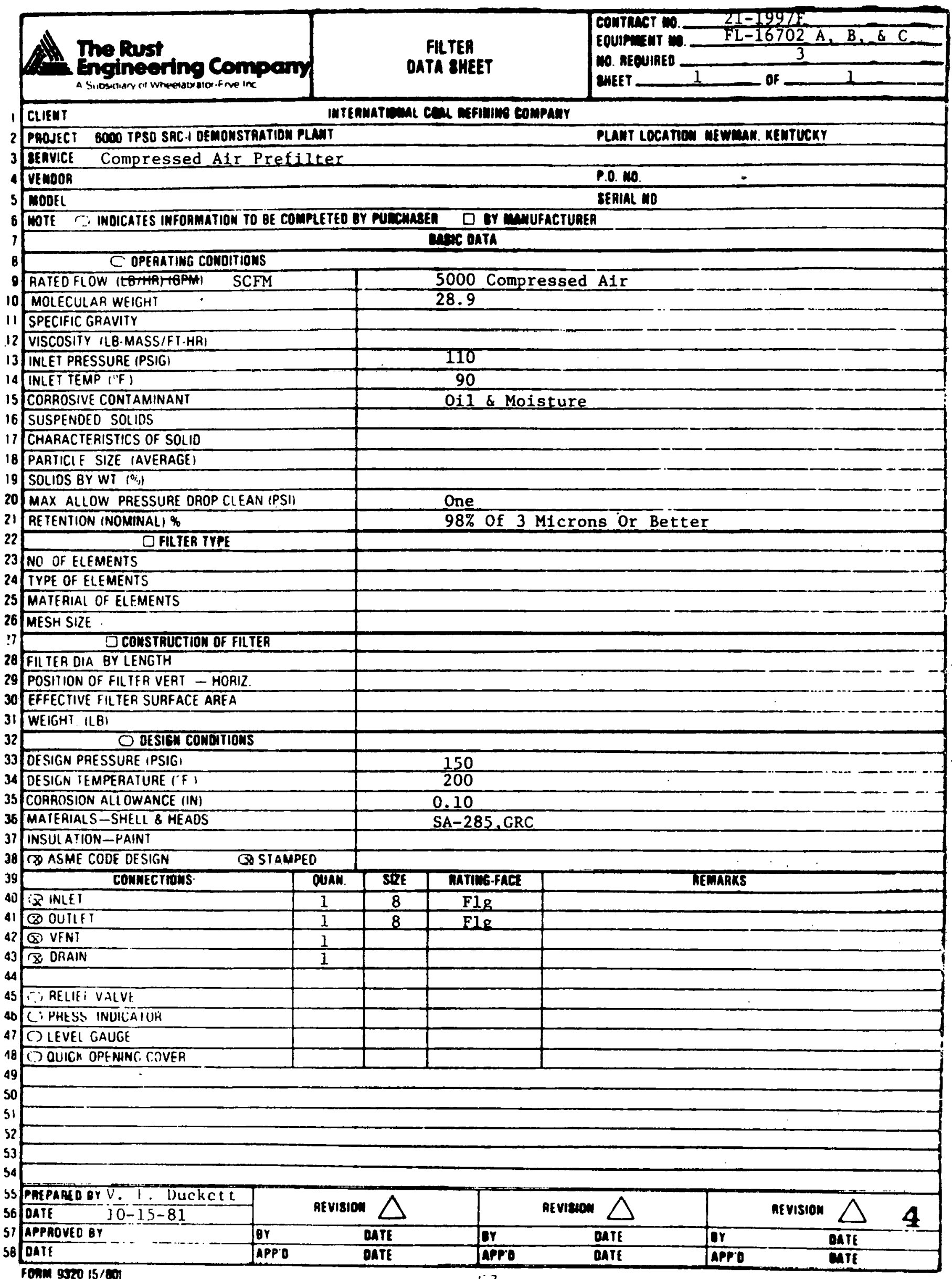




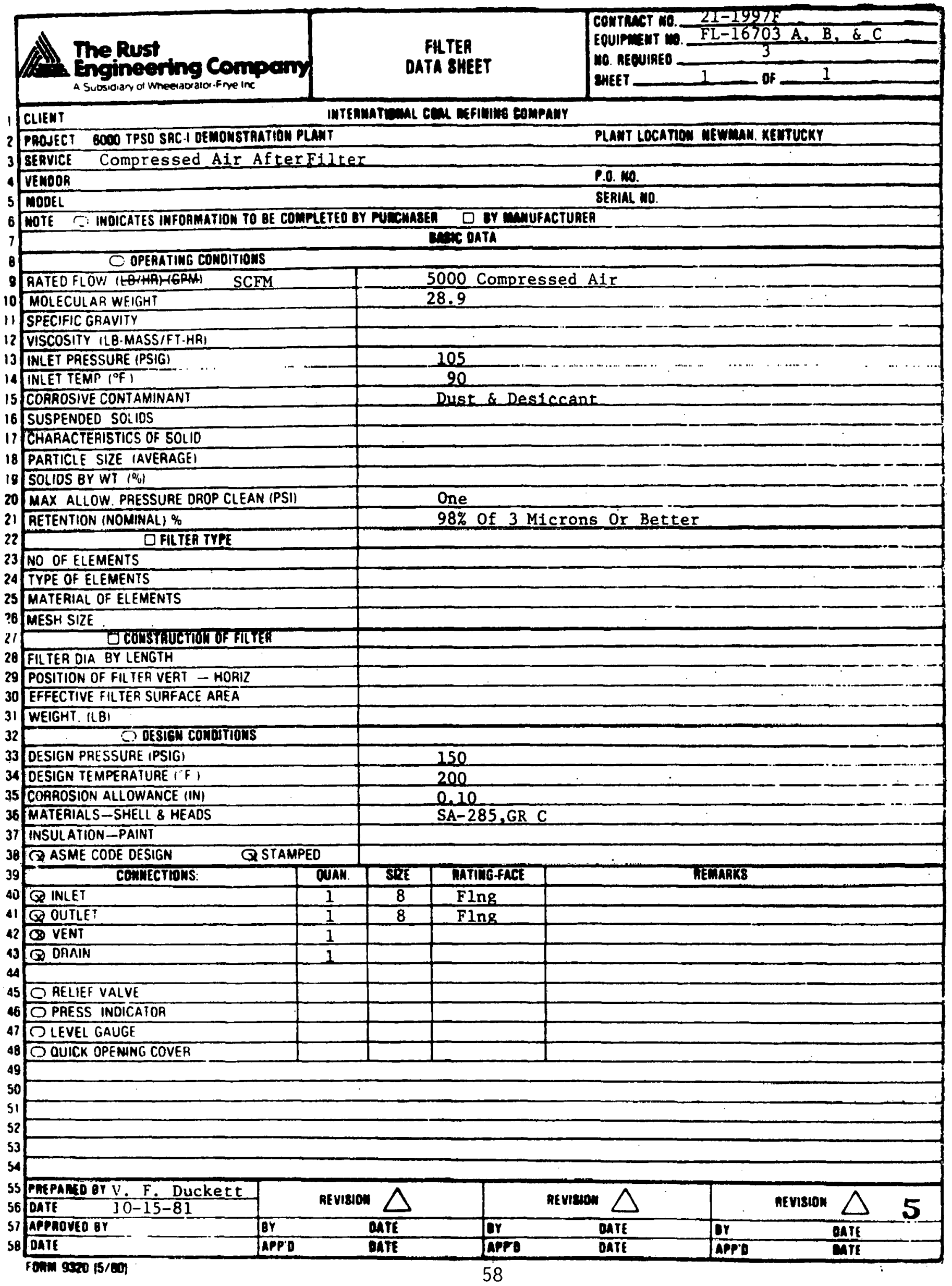




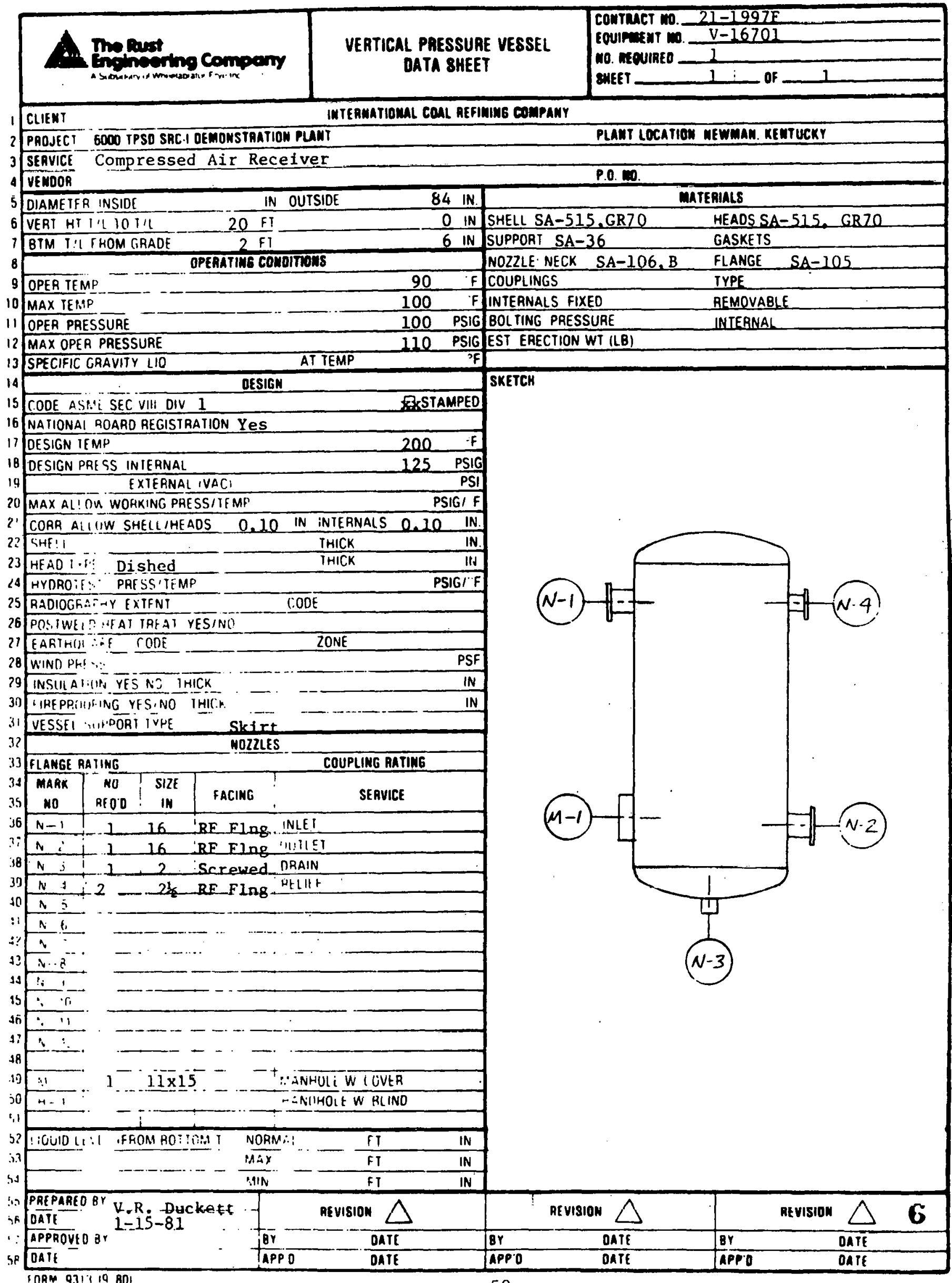




\subsubsection{Flare and Incinerators}

\subsubsection{System Description}

\subsection{Flare System}

\subsection{Design Criteria}

Hydrocarbon Kelease (ReIer Lu Design Basia Mcmorandum, Paragraph $1-b$ of this dorument.)

Max allowable flare tip delta $P$, psi

0.5

Amblent temperature (average), ${ }^{\circ} F$

70.0

Wind velocity, mph

20.0

Max radiation at grade, Btu/hr- $\mathrm{ft}^{2}$ $2,000.0$

Max radiation at liquid or solid storage facilities, Btu/hr-ft ${ }^{2}$ $1,500.0$

Max mach number at flare tip

Max allowable backpressure at unit battery limits, psig 20.0

Max HC rate for smokeless operation, MM $1 \mathrm{bs} / \mathrm{hr}$ 0.2

Steam rate for smokeless operation, Ib steam/1b HC

\subsection{Deocription}

2.2.9.1.1.2.1 The 6,000 TPD demonstration plant will have a single derricktype elevated flare, designed to handle 1.0 million pounds per hour of hydrocarbon emissions.

2.2.9.1.1.2.2 The flare system will include a relief valve collecting manitold wthin each of the process areas. To minimize piping requirements, the individual relief valves will tle 1nto cullecting brancheo, whtch will jain finto a oingle manifold discharging into a blow-down drum. 
2.2.9.1.1.2.3 Each process area will have a captive blow-down drum. Each drum will operate at 20 psig maximum. The dissolver area blow-down drum will operate at 230 psig. The high pressure blow-down drum will discharge into the Catalytic process area blow-down drum. Each operating area blow-down drum will have facilities to pump out disengaged liquid, and/or vaporize it by steam heating, using dimple jackets or coils.

\subsection{4 The dissolver area high pressure blow-down drum will also have a} quenching system designed to spray cold quench liquid at 1,500 gpm maximum into the dissolver relief valve effluent. The quench liquid for this application will be stored in a captive $5,000 \mathrm{bbl}$ cone-roof storage tank. The quench liquid supply pumps will be steam turbine and electric motor driven and instrumented so that operation will be automatic, anticipating a dissolver malfunction. If the system is activated by the anticipating signal and no release occurs, the blow-down drum pumps will return the quench liquid to storage. Should a release occur, the quenched material will be returned to the process area for reprocessing.

\subsection{5 Each process area blow-down drum will discharge into a main flare line manifold; which will then discharge into a vertical $44 \mathrm{ft}$ diameter by $69 \mathrm{ft}$ separator. The separator will be designed to disengage 1iquid and provide the proper elevation at the battery limits so that the main flare line will have the proper downward slope (0.1 inch each 10 feet) to the knockout drum located at the flare derrick base.}

\subsection{6 The main flare 11 ne w1ll be 46 inches od. It will start at} the vertical separator and extend 3,000 feet to the horizontal separator at the base of the flare derrick.

2.2.9.1.1.2.7 The main flare line will have 8 full-moment anchors at 400 foot intervals. Each 400 foot section w1ll have eight other pipe supports and a thermal expansion loop designed to keep the stresses within allowable limits for a $1.1 \mathrm{~mm}$ pounds per hour release. A total of 68 pipe supports will be required. 
2.2.9.1.1.2.8 The horizontal $22 \mathrm{ft}$ dia by $80 \mathrm{ft}$ knockout drum at the base of the flare derrick will have pumping and vaporizing capabilities to return condensate to process and/or vaporize. It for flaring. This drum and all associated peripheral piping will be insulated for an environmental factor of 0.1 . Sections will be fireproofed as required.

2.2.9.1.1.2.9 Vapors from the horizontal $22 \mathrm{ft}$ diameter by $80 \mathrm{ft}$ drum will discharge into the flare stack seal pot, which will isolate the main flare header from the derrick stack by a water seal. The pressure required to break this water seal will not exceed 0.5 psi. Under normal, no-emission conditions, the only material being sent to the flare stack will be efther purge nitrogen or purge fuel gas. Use of these materlals will be minimized by the molecular seal upstream of the flare tip.

2.2.9.1.1.2.10 The flare stack and ail required utility lines will be supported by the derrlck. The flare stack will be held by loose joints, to permit vertical expansion. The ut1lity lines attached to the stack will move vertically with the stack.

2.2.9.1.1.2.11 For improved service life, the upper 50 feet of flare stack will be 316 stainless steel, including the molecular seal, flare tip, pilots, and utility piping. The flare tip will have six continuously-burning LPG pilots.

2.2.9.1.1.2.12 The ignitor system will be an integral package with LPG backup, located out of the "dead zone". The systeni will be housed in an open shack facing away from the flare line-of-sight. The roof and walls facing the flare w111 be insulated and covered with reflective material.

\subsection{Sizing Criteria}

2.2.9.1.1.3.1 Flare sizing was done following a system analysis, which reviewed in detail all causes and the resulting flare loads from the individual process areas. The resulting flow rates were based on data 
supplied by the individual area contractors, overall process material balances, and unit flow diagrams. The following cases were individually reviewed:

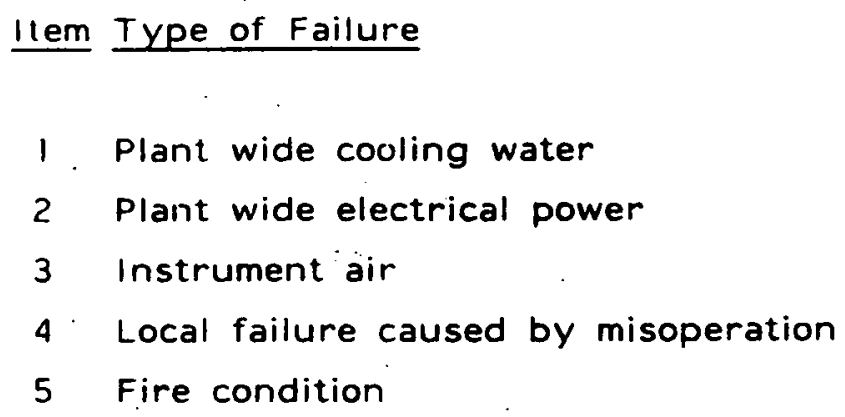

2.2.9.1.1.3.2 The governing condition for this plant is a combination of plani wide cooling water and power failure, resulting in the maximum emission rate given in the Design Basis Memorandum. This includes hydrocarbon emissions, vapors containing odorous or noxious gases, and rlammable or otherwise hazardous vapors. Streams containing air were not included, as they would be disposed of in a vapor incinerator.

\subsection{Mechanical Design Criteria}

2.2.9.1.1.4.1 All vent and blow-down sub-headers will slope from the relief valves to the main branches, with a minimum slope of 0.2 inch each 10 feet. The same requirements will apply to the branches leading to the main flare header. All individual entries to and from sub-headers will be made at the top of the line. The main flare slope will be 0.1 inch each 10 feet, minimum.

2.2.9.1.1.4.2. The main flare line will be provided with 26 20-inch manways, equally spaced, for maintenance and clean-out. These manways will be horizontal with hinged davits to support the blind flange. 


\subsection{3 The flare stack will have a caged access ladder extending}

to the top of the tube, with rest platforms every 30 feet. A 360 degree work platform w111 be provided at the flare tip for maintenance. This service area will include a permanently-installed davit and hoisting device to facilitate removing and changing the flare tip assembly.

2.2.9.1.1.4.4 The flare stack will be mounted on top of the seal drum, which will be anchored to its own ground-level foundation. The flare stack will be guided by the derrick; however, it will not be ancliured at any point, to allow for free expansinn.

2.2.9.1.1.4.5 The upper 50 feet of flare stack, molecular seal, flare tip, Ignitors, and service piping will be 316 stainless steel.

\subsection{L1quid and Gas Incinerators}

\subsection{General Description}

2.2.9.1.2.1.1 To dispose of waste liquids, low-pressure hydrocarbon vents, purge gases, oxygen contaminated streams, and blanketing gases, the plant will be provided with two Incinerators, one for liquids, the other for gases.

2.2.9.1.2.1.2 Each incinerator will incorporate a waste heat recovery system which will generate saturated steam at 150 psig. Each unit will also include an individual boiler feedwater recirculation system, chemical treatment facilities, and local combustion controls with flame supervision capahility. Major alarms and current operating status will be linked to the central control room by a pan-alarm system. Each incinerator will use fuel gas as an auxiliary. tuel. 
2.2.9.1.2.1.3 Each incinerator will have a sampling platform at the required helght for flue gas composition and solid load analysis sampling. All critical temperatures, flows, and pressures required for performance calculations will be permanently recorded.

\subsection{Liquid Thermal Oxidizer}

2.2.9.1.2.2.1 The waste liquid incinerator will include a nitrogen-blanketed surge tank where the waste liquids from the various plant sources will be recelved. Venting from this tank will be disposed of in a special burner in the incinerator.

2.2.9.1.2.2.2 Waste liquids, at a maximum rate of 3,019 pounds per hour, will be pumped on level control from the surge tank to the main burner. To improve waste liquid combustion and assist in mechanical atomization, the waste liquid will be preheated by steam, to the required temperature where viscostty is no longer a controlling factor. The required pumping and preheating equipment will be part of the incinerator package.

2.2.9.1.2.2.3 To completely incinerate the anticlpated wastes, the firebox must operate at above $2,000^{\circ} \mathrm{F}$ at a slightly negative pressure.

\subsection{Vent Gas Incinerator}

2.2.9.1.2.3.1 The vent gas incinerator will include an induced draft fan to collect low-pressure hydrocarbon vent gases from the various sources. The induced draft fan will maintain a constant volume to the incinerator, using an atmospheric air trim to maintain a constant sub-atmospheric pressure. The maximum anticipated combustible material flow rate will be about 2,500 pounds per hour. 
2.2.9.1:2.3.2 To separate entrained liquids, the vent gas collecting manifold will discharge into a knock-out drum. The condensed liquid will then be pumped to the liquid thermal oxidizer surge tank for disposal. The vapors will be enriched, if required, with fuel gas to the minimum level that will support steady combustion.

2.2.9.1.2.3.3 The enriched vapors will be mixed with combustion air in a low-pressure-drop, high-efficiency burner. Expected firebox temperature for complete vapor oxidation is about $2,500^{\circ} \mathrm{F}$ at a slightly negative pressure:

\subsubsection{Utility Flow Diagrams}

The following utility flow diagrams are included after this page:

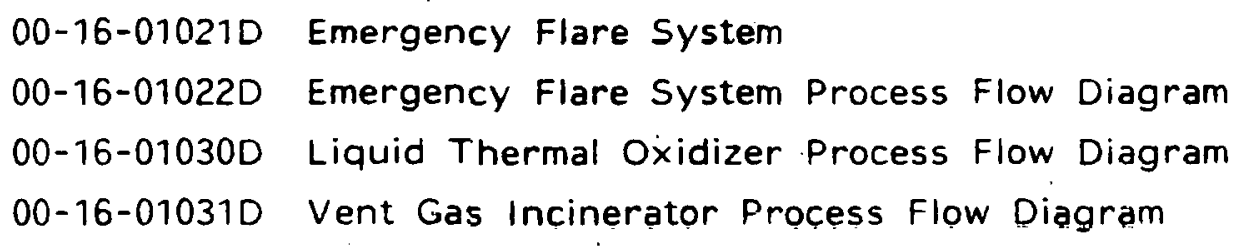




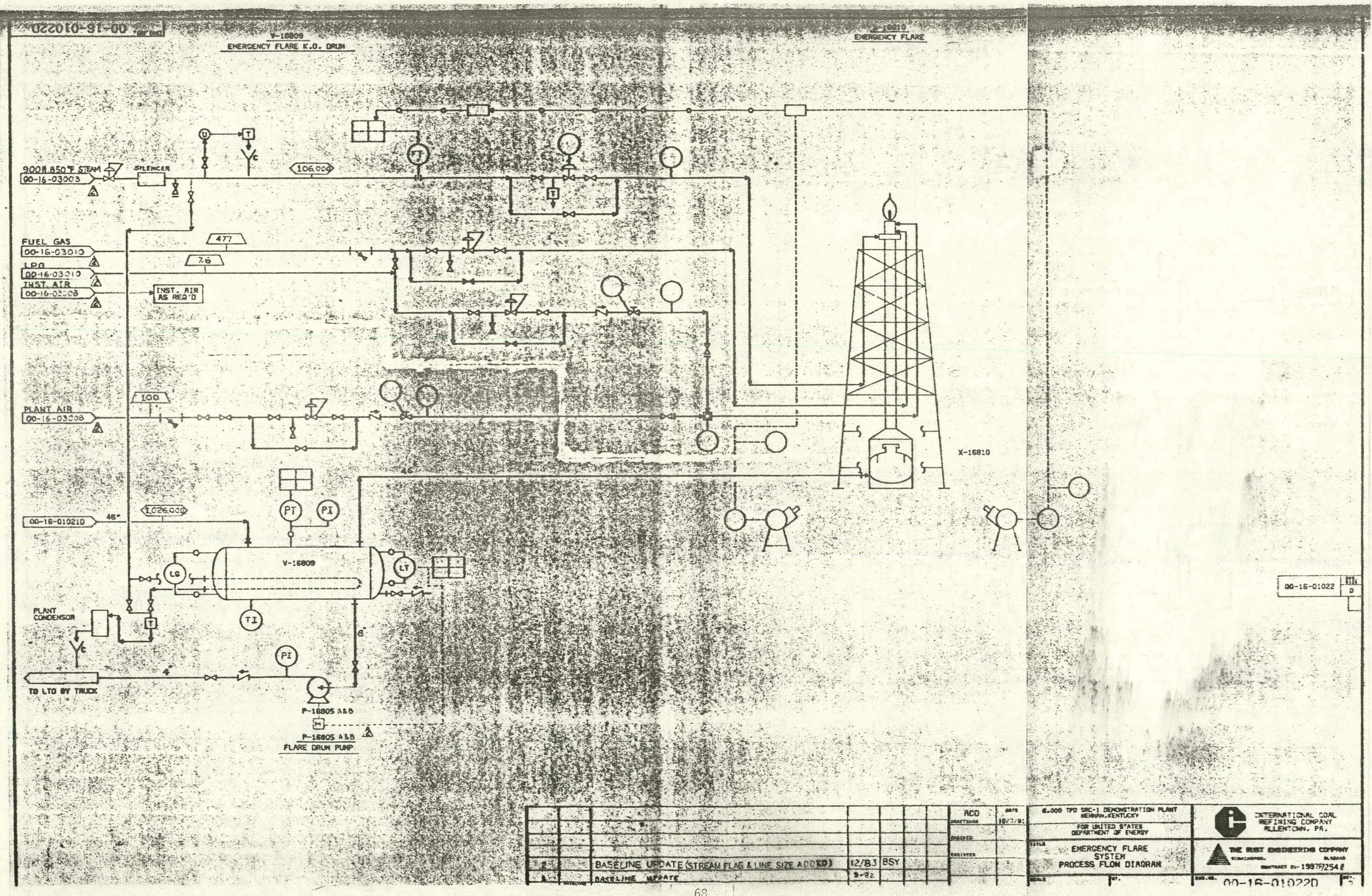




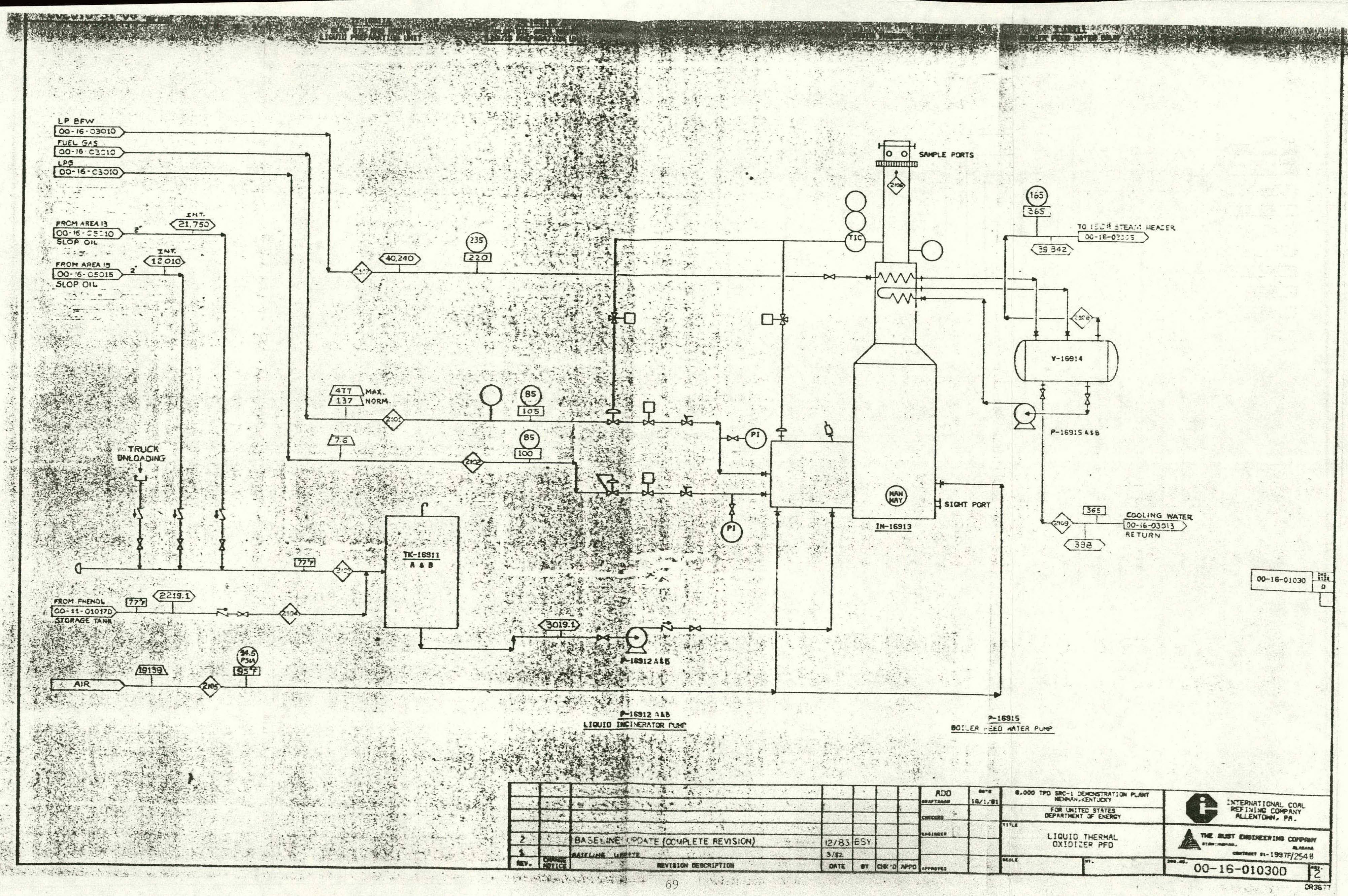




\subsubsection{Material and Energy Balances}

The material and energy balances for the liquid thermal oxidizer system are included after this page. 


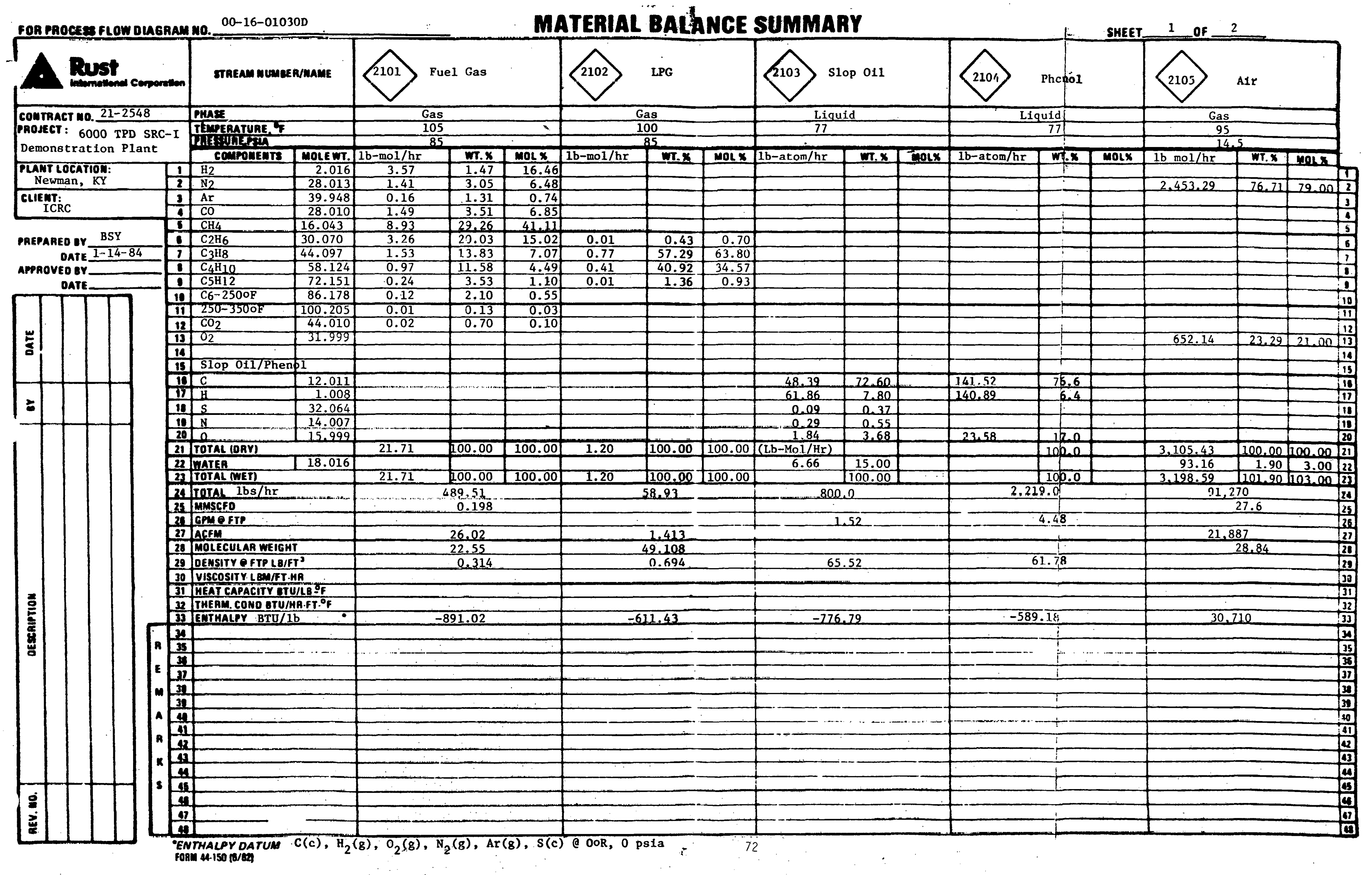




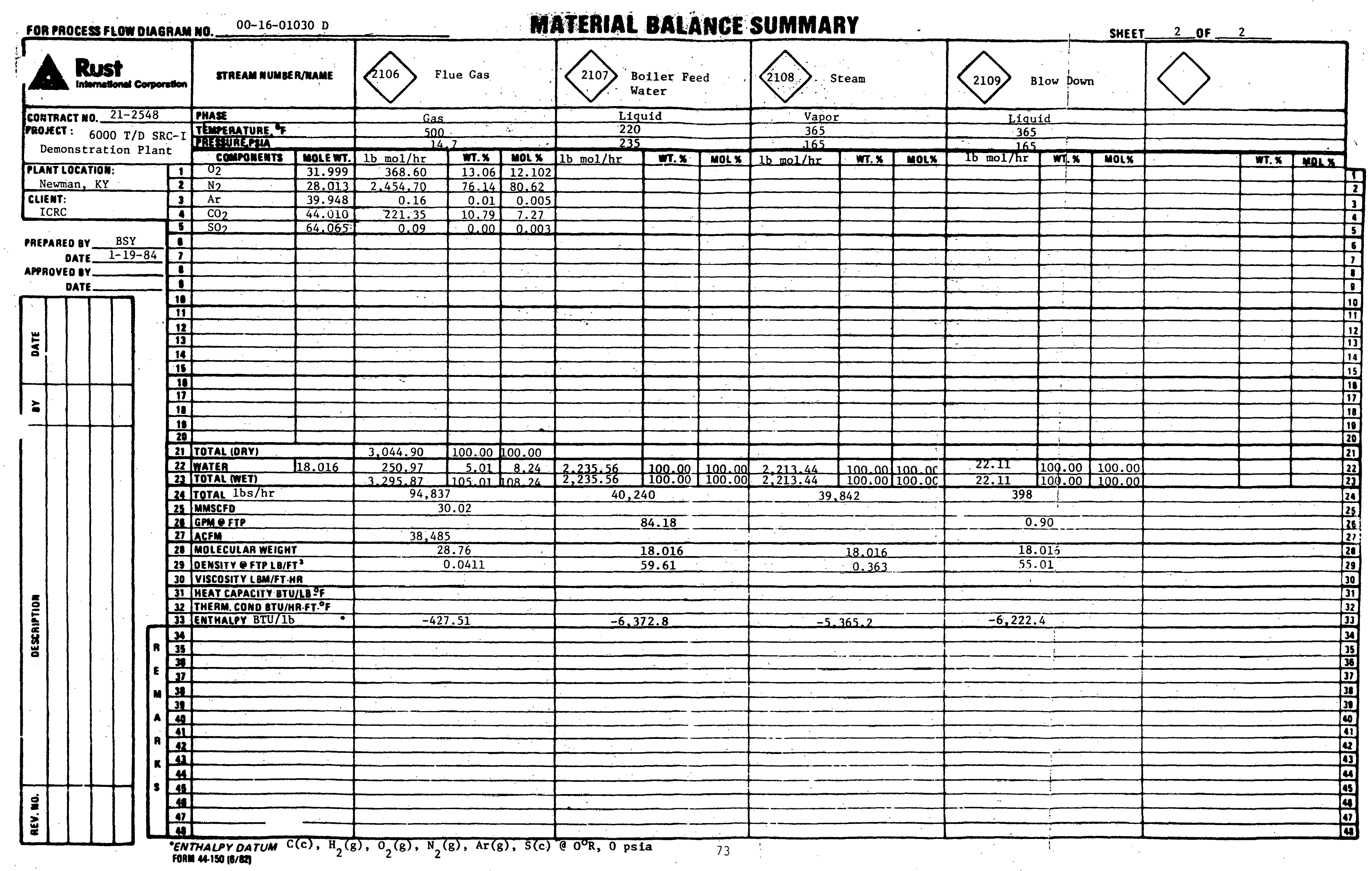




\subsubsection{Utility Summary}

The utility summary for the flare and incinerators follows this page. 


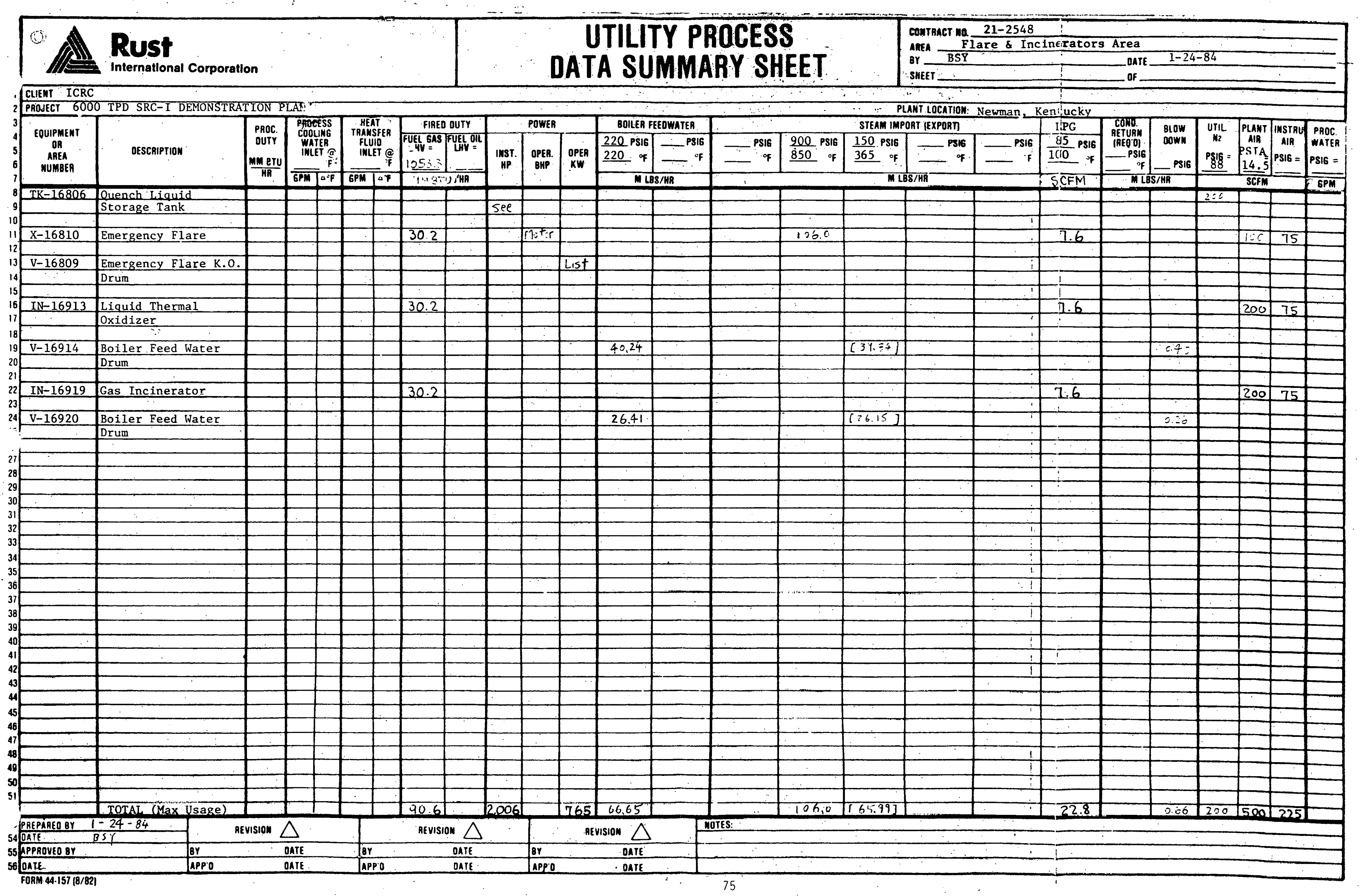


2.2.9.5 Motor List

The motor list for the flare and incinerators follows this page. 


\section{Item}

P-16801A

P-16801B

P-16802A

P-16802B

P-16806A

P-16806B

P-16807A

P-16807B

$\mathrm{P}-16803 \mathrm{~A}$

P-16803B

P-16804A

P-16804B

$\mathrm{P}-16800 \mathrm{~A}$

$\mathrm{P}-1680{ }_{\mathrm{B}}$

C-16917

P-16918A

P-16918B

P-16921A

P-16921B

P-16912A

P-16912B

P-16915A

P-16915B
Description

Quench Liquid Pump

Quench Liquid Pump

Knockout Pump

Knockout Pump

Knockout Pump

Knockout Pump

Knockout Pump

Knockout Pump

Knockout Pump

Knockout Pump

Liquid Recovery Pump

Liquid Recovery Pump

Flare Drum Pump

Flare Drum Pump

Induced Draft Fan

Condensate Transfer Pump

Condensate Transfer Pump

Boller Feedwater Pump

Bo1ler Feedwater Pymp

Liquid Incinerator Pump

Liquid Incinerator Pump

Boiler Feedwater Pump

Boiler Feedwater Pump

TOTAL
Conn

HP.

500

500

20

20

60

60

20

20

200

200

20

20

20

20

100

10

10

40 .

40

3

3

60

60

Oper

360

150

15

75
75

$24 \quad 1,800$

0

15

0

45

0

15

0

0

0

15

0

Hrs /

Day

KWH /

Day

\section{0}

0

0

0

0

0

0

0

0

0

0

0

0

$0 \quad 0$

$\begin{array}{lll}6.5 & 24 & 156^{\circ}\end{array}$

$0 \quad 0 \quad 0$

$30 \quad 24 \quad 720$

$0 \quad 0 \quad 0$

$\begin{array}{lll}1.5 & 24 & 36\end{array}$

$0 \quad 0 \quad 0$

$\begin{array}{lll}37 & 24 & 888\end{array}$

$0 \quad 0 \quad 0$




\subsubsection{Equipment List/Summary}

The equipment list/summary for the flare and incinerators follows this page. 


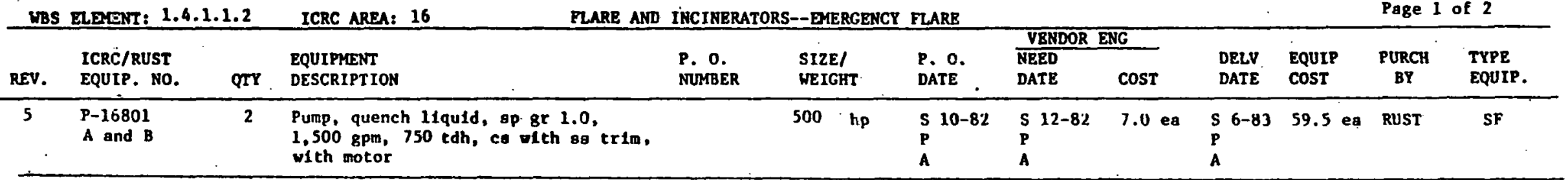

\begin{tabular}{|c|c|c|c|c|c|c|c|c|c|c|c|}
\hline 5 & $\begin{array}{l}P-16803 \\
A \text { and } B\end{array}$ & 2 & $\begin{array}{l}\text { Pump, knockout, op gr } 1.0,1,500 \mathrm{gpm}, \\
250 \text { tdh, cs with } 88 \text { trin, with motor }\end{array}$ & $200 \mathrm{hp}$ & $\begin{array}{l}\text { S } 10-82 \\
\text { P } \\
\text { A }\end{array}$ & $\begin{array}{l}\text { S } 12-82 \\
\text { P } \\
\text { A }\end{array}$ & $2.3 \mathrm{ea}$ & $\begin{array}{l}\text { S } 6-83 \\
\text { P } \\
\text { A }\end{array}$ & 19.2 & RUST & SF \\
\hline 5 & $\begin{array}{l}P-16804 \\
A \text { and } B\end{array}$ & 2 & $\begin{array}{l}\text { Pump, liquid recovery, sp gr } 1.0 \text {, } \\
\text { 150 8pm, } 250 \text { tdh, cs with } 89 \text { trim, } \\
\text { with motor }\end{array}$ & 20 hp & $\begin{array}{l}\text { S } 10-82 \\
\text { P } \\
\text { A }\end{array}$ & $\begin{array}{ll}\text { S } & 12-82 \\
\text { P } & \\
\text { A }\end{array}$ & 0.9 ea & $\begin{array}{l}\text { S } 6-83 \\
\text { P } \\
\text { A }\end{array}$ & $7.8 \mathrm{eg}$ & RUST & $\mathbf{S r}$ \\
\hline 5 & $\begin{array}{l}P-16805 \\
A \text { and } B\end{array}$ & 2 & $\begin{array}{l}\text { Pump, flare drum, ep gr } 1.0 \text {, } \\
150 \mathrm{gpm}, 250 \mathrm{tdh} \text {, c8 with } 88 \mathrm{trls} \text {, } \\
\text { with motor }\end{array}$ & $20 \mathrm{hp}$ & $\begin{array}{l}\text { S } 10-82 \\
\text { P } \\
\text { A }\end{array}$ & $\begin{array}{l}\text { S } 12-82 \\
\text { P } \\
\text { A }\end{array}$ & 0.9 ea & $\begin{array}{l}\text { S } \\
\text { P-83 } \\
\text { A }\end{array}$ & $7.8 \mathrm{ea}$ & RUST & SF \\
\hline 5 & TR- 16806 & 1 & $\begin{array}{l}\text { Tank, storage, quench liquid, } \\
5,000 \text { bb1 nominal, c8, A.PI } 650\end{array}$ & ${ }_{\times 35^{\prime}} \mathrm{d}^{\prime}$ & $\begin{array}{l}\text { s } 10-82 \\
\text { P } \\
\text { A }\end{array}$ & $\begin{array}{l}\text { S } 1-83 \\
\text { P } \\
\text { A }\end{array}$ & $6.4 \mathrm{ea}$ & $\begin{array}{l}\text { S } 10-83 \\
\text { P } \\
\text { A }\end{array}$ & 54.4 & CHC & $\mathbf{F P}$ \\
\hline
\end{tabular}

10TES: All costs lat Quarter Flacal Year 1982 in thousand dollars.

2. Equ coste lat Quarter Flocal year 1982 in thougand doliars.

support less vendor engineering.

3. This equiprent is Appendix C Bulks
RUST: RUST Englneering

Stone \& Hebster

S: Scheduled
P: Projected
A: Actual

A: Actual
FL: Fleld Labor Materlal for fleld
SF: Shop Fabricated

N/A: Not Applicable FF: Field Fabricated 
EQUIPRENI LIST/SUSDURY

REv. 5

12-30-83

WBS ELETENT: 1.4.1.1.2

ICRC AREA: 16

FLARE AND INCIEERATORS-- EMERGENCY FLARE

Page 2 of 2

\begin{tabular}{|c|c|c|c|c|c|c|c|c|c|c|c|c|}
\hline BEV. & $\begin{array}{l}\text { ICRC/RUST } \\
\text { EQUIP. HO. }\end{array}$ & $Q T Y$ & $\begin{array}{l}\text { EQUUIPKENT } \\
\text { DESCRIPTION }\end{array}$ & $\begin{array}{l}\text { P. O: } \\
\text { MURTER }\end{array}$ & $\begin{array}{l}\text { SIZE } f \\
\text { WEIGHT }\end{array}$ & $\begin{array}{l}\text { P. } 0 . \\
\text { DATE }\end{array}$ & $\begin{array}{l}\text { VENDDR } \\
\text { DEED } \\
\text { DATE }\end{array}$ & $\cos$ & $\begin{array}{l}\text { DELV } \\
\text { DATE }\end{array}$ & $\begin{array}{l}\text { EQUIP } \\
\text { COST }\end{array}$ & $\begin{array}{l}\text { PURCH } \\
\text { BY }\end{array}$ & $\begin{array}{l}\text { TYPE } \\
\text { EQUIP. }\end{array}$ \\
\hline 5 & $v-16808$ & 1 & $\begin{array}{l}\text { R7ockout drum, vertlcal, } 150 \text { psig, } \\
900^{\circ} \mathrm{F}, \mathrm{c} . \mathrm{s} \text {. }\end{array}$ & . & $\begin{array}{l}44^{\prime} d 1 \mathrm{da} \\
\times 69^{\prime} \mathrm{TT}\end{array}$ & $\begin{array}{l}\text { S } 10-82 \\
\text { P } \\
\text { A }\end{array}$ & $\begin{array}{l}\text { S 1-B? } \\
\text { P } \\
A\end{array}$ & 70.0 & $\begin{array}{l}\text { S } 10-83 \\
\text { P } \\
\text { A }\end{array}$ & 660.0 & RUST & SF \\
\hline 5 & $v-16809$ & 1 & Knsckout drum, 150 psig, 6500F, es & & $\begin{array}{l}22^{\prime} \mathrm{dfa} \\
\times 80^{\circ} \mathrm{TT}\end{array}$ & $\begin{array}{l}\text { S } 10-82 \\
\text { P } \\
\text { A }\end{array}$ & $\begin{array}{l}\text { S } 1-83 \\
\text { P } \\
\text { A }\end{array}$ & 34.0 & $\begin{array}{l}\text { S } 10-83 \\
\text { P } \\
\text { A }\end{array}$ & 291.0 & RUST & $\overline{\text { SF }}$ \\
\hline 5 & $x-16810$ & 1 & 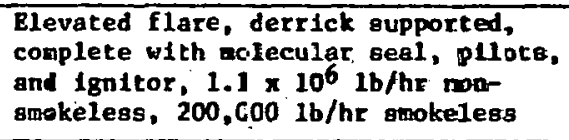 & & $\begin{array}{l}46^{\prime \prime} \text { d1a } x \\
250^{\circ} \text { hlgh }\end{array}$ & $\begin{array}{l}\text { S } 10-82 \\
\text { P } \\
\text { A }\end{array}$ & $\begin{array}{l}\text { s } 11-82 \\
\text { p }\end{array}$ & 77.0 & $\begin{array}{l}\text { S }^{2-83} \\
\text { P }\end{array}$ & $\begin{array}{r}.663 .8 \\
.\end{array}$ & CAc & $\overline{\mathbf{S F}}$ \\
\hline$\overline{4}$ & $\begin{array}{l}\mathrm{x}-16810 \\
\text { cont. }\end{array}$ & & $\begin{array}{l}26.0 \text { aolecular welght, } 0.5 \mathrm{lb} / \mathrm{hr} \\
\text { steam/1b he., }\end{array}$ & & & & & & & & CMC & SF \\
\hline
\end{tabular}

$\infty$

\section{Bores:}

1. All costa lat Quarter Flece: Year 1982 in thougend dollerg. RUST: RUST Engineering

2. Equipaent costs are POB jobstte with ohipping \& vendor tleid Gic: stone \& Yebster support less

3. This equipsent is Appendix $C$ Bulke

$\begin{array}{lll}\text { S: Scheduled } & \text { FL: Field Labor } & \text { N/A: Hot Applicable } \\ \text { P: Profected } & \text { K: Material for field } & \text { FF: Fleld Fabricated } \\ \text { A: Actial } & \text { Fab equipment } & \\ \text { ti Shop Fabricated } & .\end{array}$


EQUIPHERT LIST/SUMAMRT

REV. 5

12-30-83

WBS ERgitart 1.4.1.1.2

ICRe area: 16

PLARB AND IHCINERATORS-LIOUID THERMAL OXIDIZER

Page 1 of 1

\begin{tabular}{|c|c|c|c|c|c|c|c|c|c|c|c|}
\hline \multirow[b]{2}{*}{ kev. } & \multirow[b]{2}{*}{$\begin{array}{l}\text { ICRC/RUST } \\
\text { EQUIP. NO. }\end{array}$} & \multirow[b]{2}{*}{ QTY } & \multirow[b]{2}{*}{$\begin{array}{l}\text { EQUIPARKT } \\
\text { DESCRIPTION }\end{array}$} & \multirow[b]{2}{*}{$\begin{array}{l}\text { SIZE/ } \\
\text { WRIGHT }\end{array}$} & \multirow[b]{2}{*}{$\begin{array}{l}\text { P. } 0 . \\
\text { DATE }\end{array}$} & \multicolumn{2}{|c|}{ VEXDOR ENG } & \multirow[b]{2}{*}{$\begin{array}{l}\text { DELV } \\
\text { DATE }\end{array}$} & \multirow[b]{2}{*}{$\begin{array}{l}\text { EQUIP } \\
\text { COST }\end{array}$} & \multirow[b]{2}{*}{$\underset{\text { BY }}{\text { PORCH }}$} & \multirow[b]{2}{*}{$\begin{array}{l}\text { TYPE } \\
\text { EQUIP. }\end{array}$} \\
\hline & & & & & & $\begin{array}{l}\text { NEED } \\
\text { DATE }\end{array}$ & $\operatorname{cost}$ & & & & \\
\hline 5 & $\mathrm{IN}-16913$ & 1 & $\begin{array}{l}\text { Oxidizer, liquid thermal, } 3,600 \mathrm{lb} / \mathrm{hr} \\
\text { combined capacity complete with pert- } \\
\text { pherals and Instrumentation, } 125 \mathrm{ft} \\
\text { dispersive stack; } 150 \text { psig waste heat boller }\end{array}$ & & $\begin{array}{l}\text { S } \\
\text { P } \\
\text { A }\end{array}$ & $\begin{array}{l}\text { S } \\
\text { P } \\
\text { A }\end{array}$ & 30.3 & $\begin{array}{l}\text { S. 6-83 } \\
\text { P } \\
\text { A }\end{array}$ & & RUST & SF \\
\hline$=$ & $\begin{array}{l}\mathrm{P}-16912 \\
\mathrm{~A} \text { and } \mathrm{B}\end{array}$ & 2 & $\begin{array}{l}\text { Pump, liquid Incinerator, } 20 \text { gpw } \times 231 \\
\text { tdh, c.s. with ss trim, with wotor }\end{array}$ & 3 hp & $\begin{array}{l}\text { S } 10-82 \\
\text { P. }\end{array}$ & $\begin{array}{l}\text { S } 12-82 \\
\text { P }\end{array}$ & $\begin{array}{l}\text { Inc } w / \\
\text { IK-16913 }\end{array}$ & $\begin{array}{l}5 \text { 6-83 } \\
\text { P }\end{array}$ & $\begin{array}{l}\operatorname{lnc}: / \\
\text { IN }-16913\end{array}$ & RUST & SF \\
\hline 5 & $\begin{array}{l}P-16915 \\
A \text { and } B\end{array}$ & 2 & 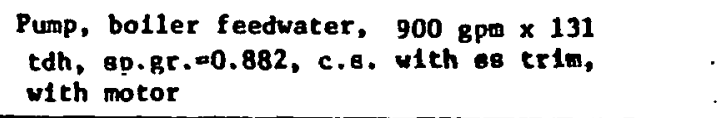 & $60 \mathrm{hp}$ & $\begin{array}{l}\text { S } \\
\text { P } \\
\text { A }\end{array}$ & $\begin{array}{l}\text { S } \\
\text { P } \\
\text { A }\end{array}$ & $\begin{array}{l}\text { Inc } w / \\
\text { IN-16913 }\end{array}$ & $\begin{array}{l}\text { S } \\
P \\
A\end{array}$ & $\begin{array}{l}\text { Inc w/ } \\
\text { IN-16913 }\end{array}$ & RUST & SF \\
\hline$\stackrel{\infty}{\mapsto !}$ & $v-16911$ & 1 & $\begin{array}{l}\text { Knockout drum, } 150 \mathrm{pgig}, 650^{\circ} \mathrm{P} \text {, } \\
\text { metal weight, } 9,788^{1 \mathrm{~b}}\end{array}$ & & $\begin{array}{l}\text { s } 10-82 \\
\text { P } \\
\text { A }\end{array}$ & $\begin{array}{ll}\text { S } & 1-83 \\
\text { P } & \\
\text { A }\end{array}$ & 2.1 & $\begin{array}{l}\text { S 10-83 } \\
\text { P } \\
\text { A }\end{array}$ & 17.8 & RUST & sF \\
\hline 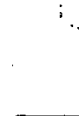 & $v-16914$ & 1 & Drum, boller feedwater & & $\begin{array}{ll}\text { S } & 10-82 \\
\text { P } & \\
A & \end{array}$ & $\begin{array}{l}\text { S } 1-83 \\
\text { P } \\
\text { A }\end{array}$ & $\begin{array}{l}\text { Inc } w / \\
\text { IN-16913 }\end{array}$ & $\begin{array}{ll}\text { S } & 10-83 \\
\text { P } & \\
\text { A } & \end{array}$ & $\begin{array}{l}\text { Inc } w / \\
\text { IN-16913 }\end{array}$ & Rust & $\mathbf{S P}$ \\
\hline
\end{tabular}

\section{Mores:}

1. All costs lat Quarter Plocal Year 1982 to thousand dollars. FUST: RUST EngIneering

2. Equipaent costs are FOB jobsite with shipping o veador fleld CAC: Stone \& Webster support less vendor englneeting.

3. This equipsent is Appendix C Bulk
S: Scheduled

P: Profected

A: Actus 1
FL: Pield Labor

tab equipwent

SF: Shop Fabricated
N/A: Not Appllcable FF: Fleld Fabricated 
EQULPMENT LIST/SURMART

REV. $5 \quad 12-30-83$

WBS ELEMTAT: 1.4.1.1.2 ICRC AREA: 16 FLARE AND IMK LHERATORS--VENT GAS INCINERATOR

Page 1 of 1

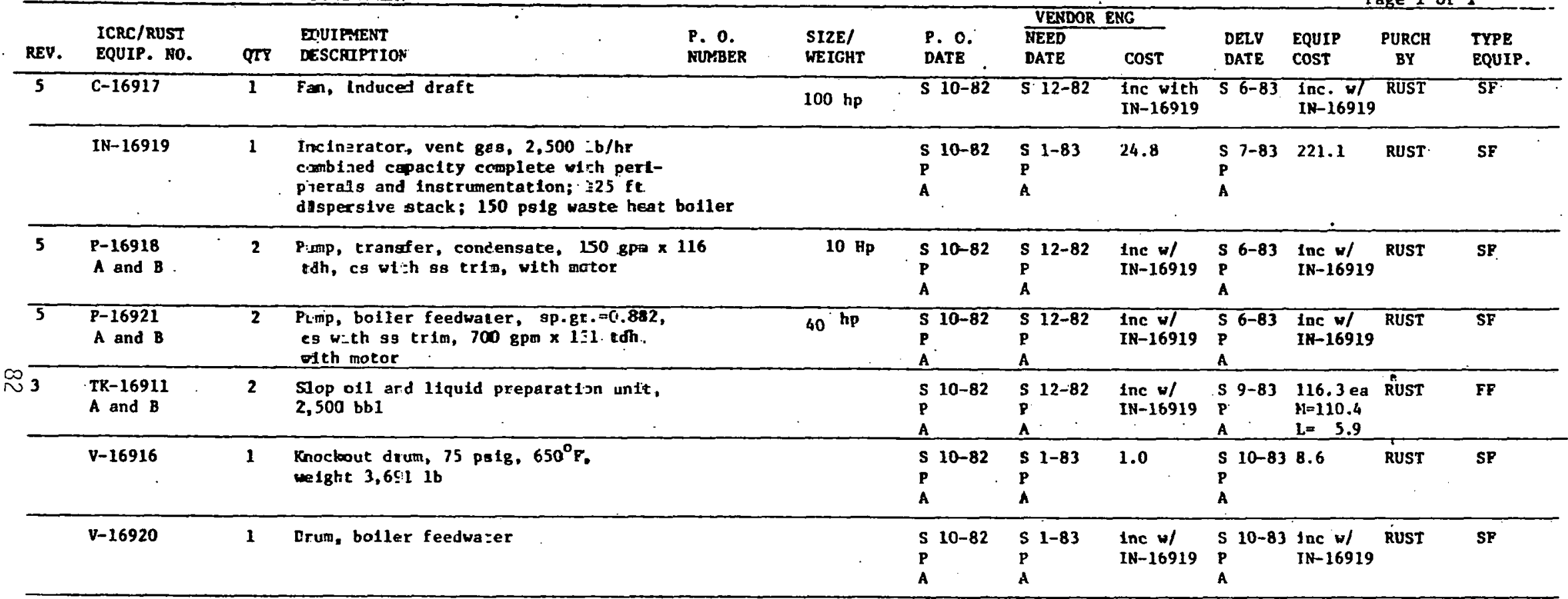

\section{mers:}

1. All costs lat Quarter Flacal Year 1982 in thousand dollars. RUST: RUST Englneerfag

2. Equipwent costs are ros jobstze with shipping \& vendor flelid CHC: Stone \& Webster Equipsent costs ate Fos jobstze

P: Profected

Bupport less vendor engineer fing.

i: Actual

PL: F1eld Labor

II: Material for fleld

H/A: Hot Appllcable

3. Thls equiptent is Append Is C Bulks

SF: Shop Fabricat

SF: Shop Fabricated 


\subsubsection{Equipment Data Sheets}

The equipment data sheets for the flare and incinerators follow this page. 


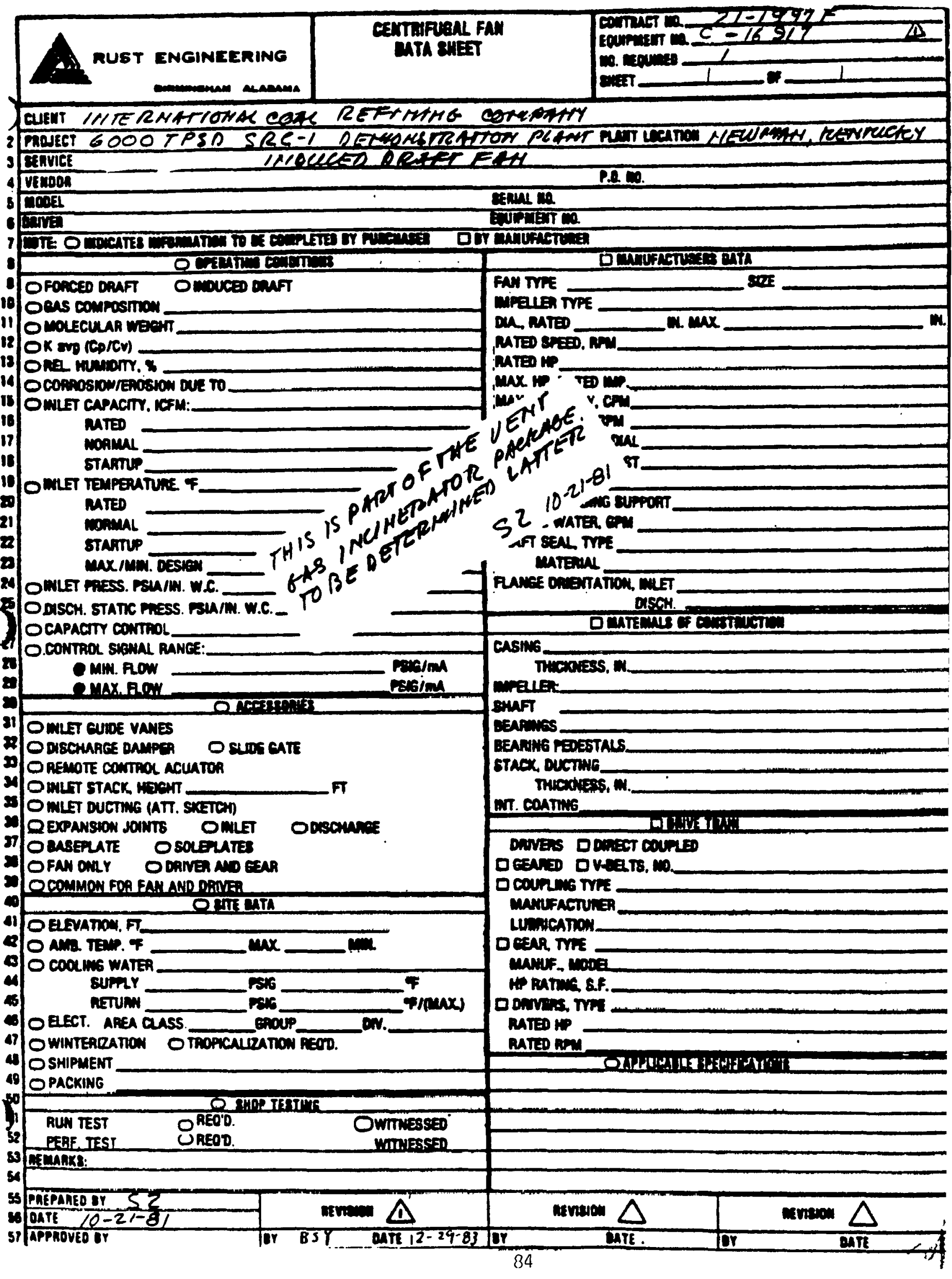




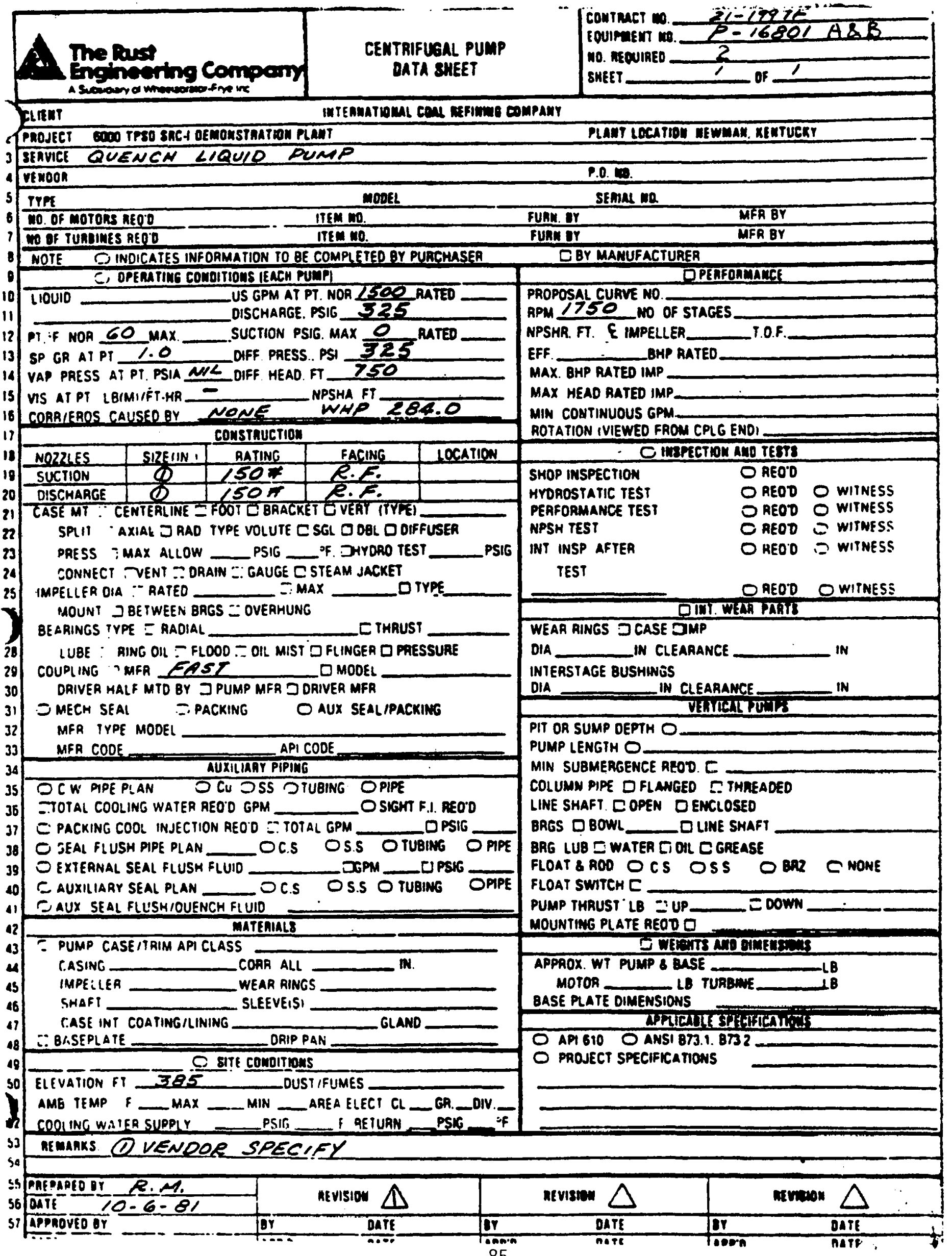




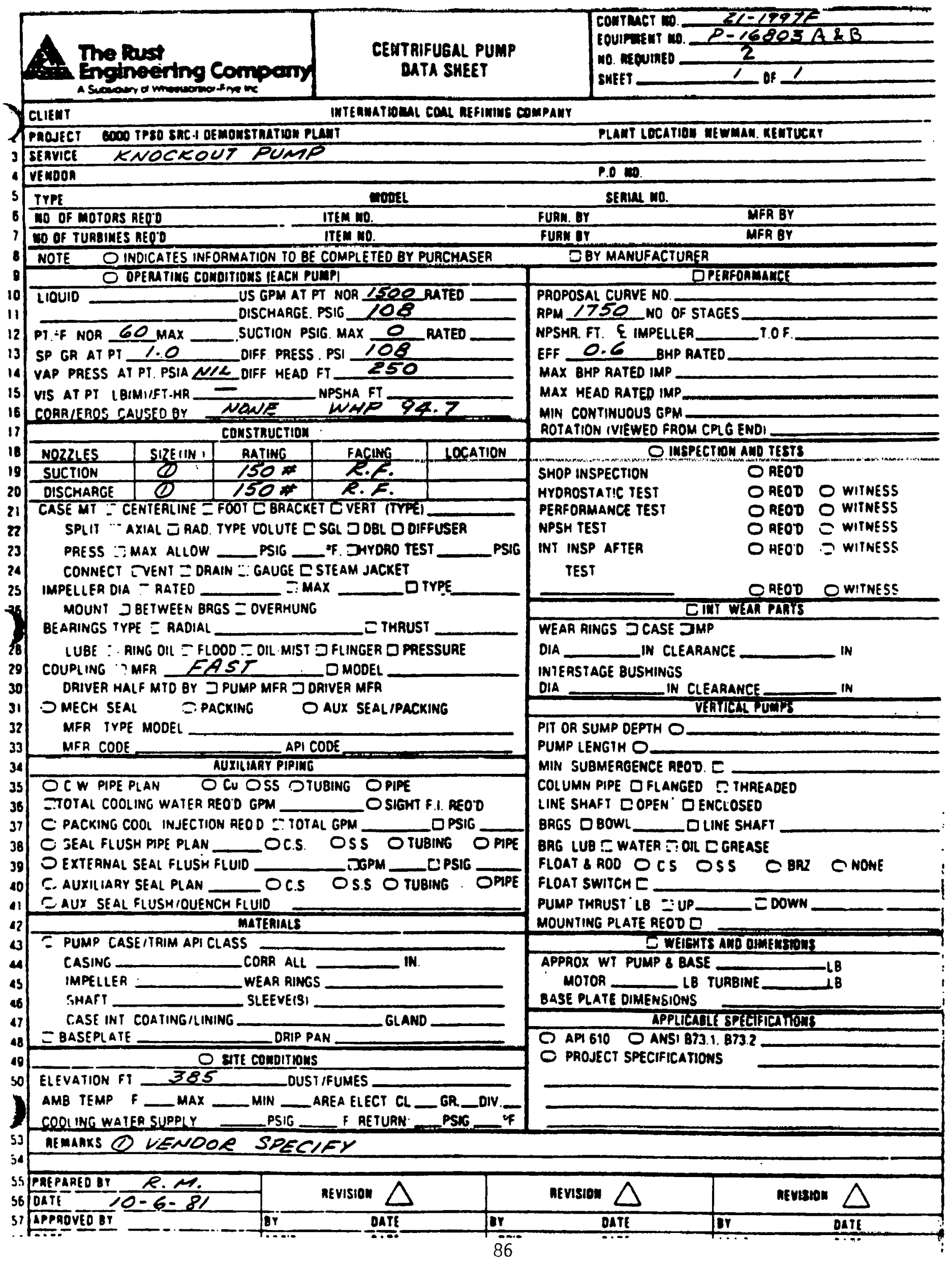




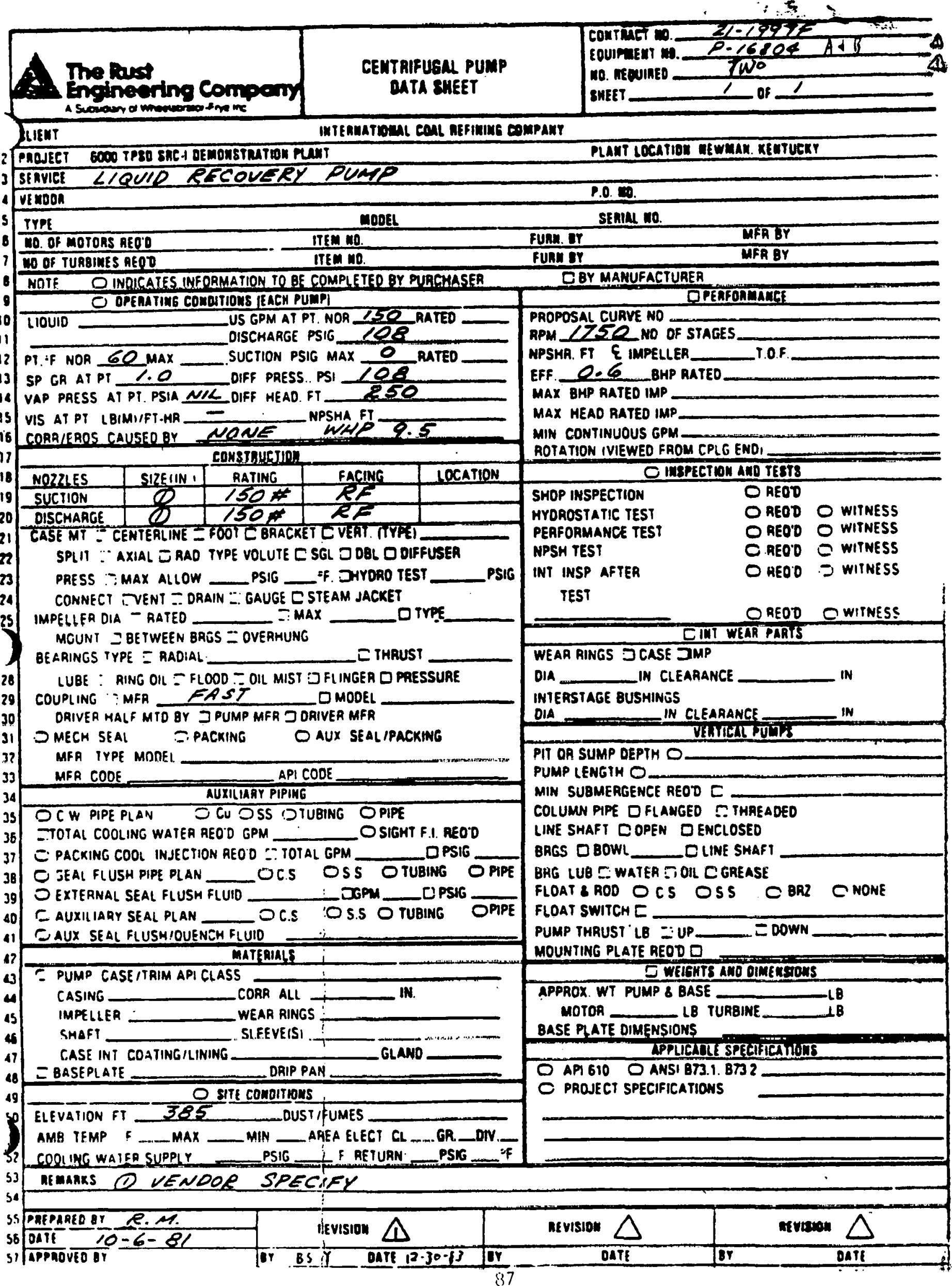




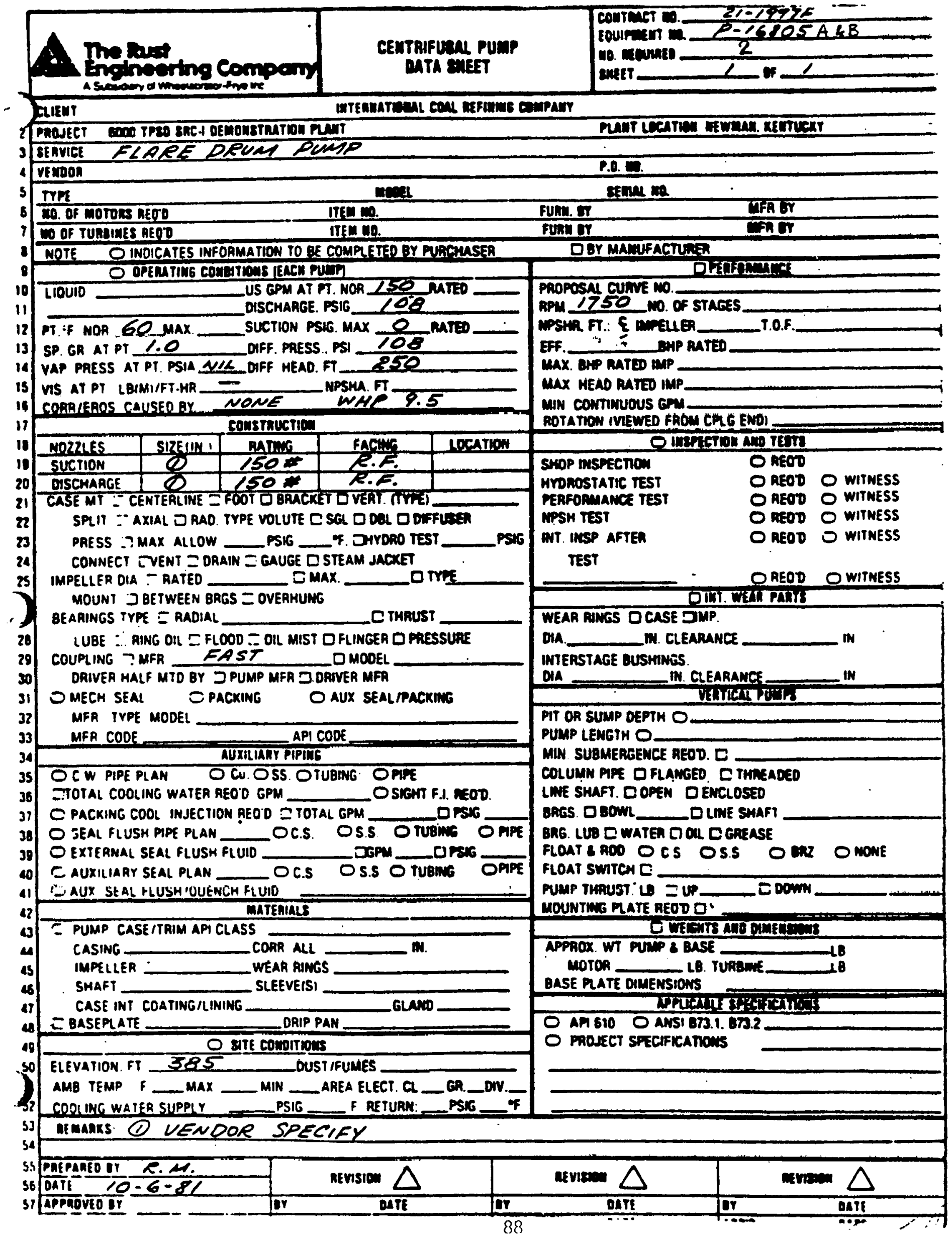




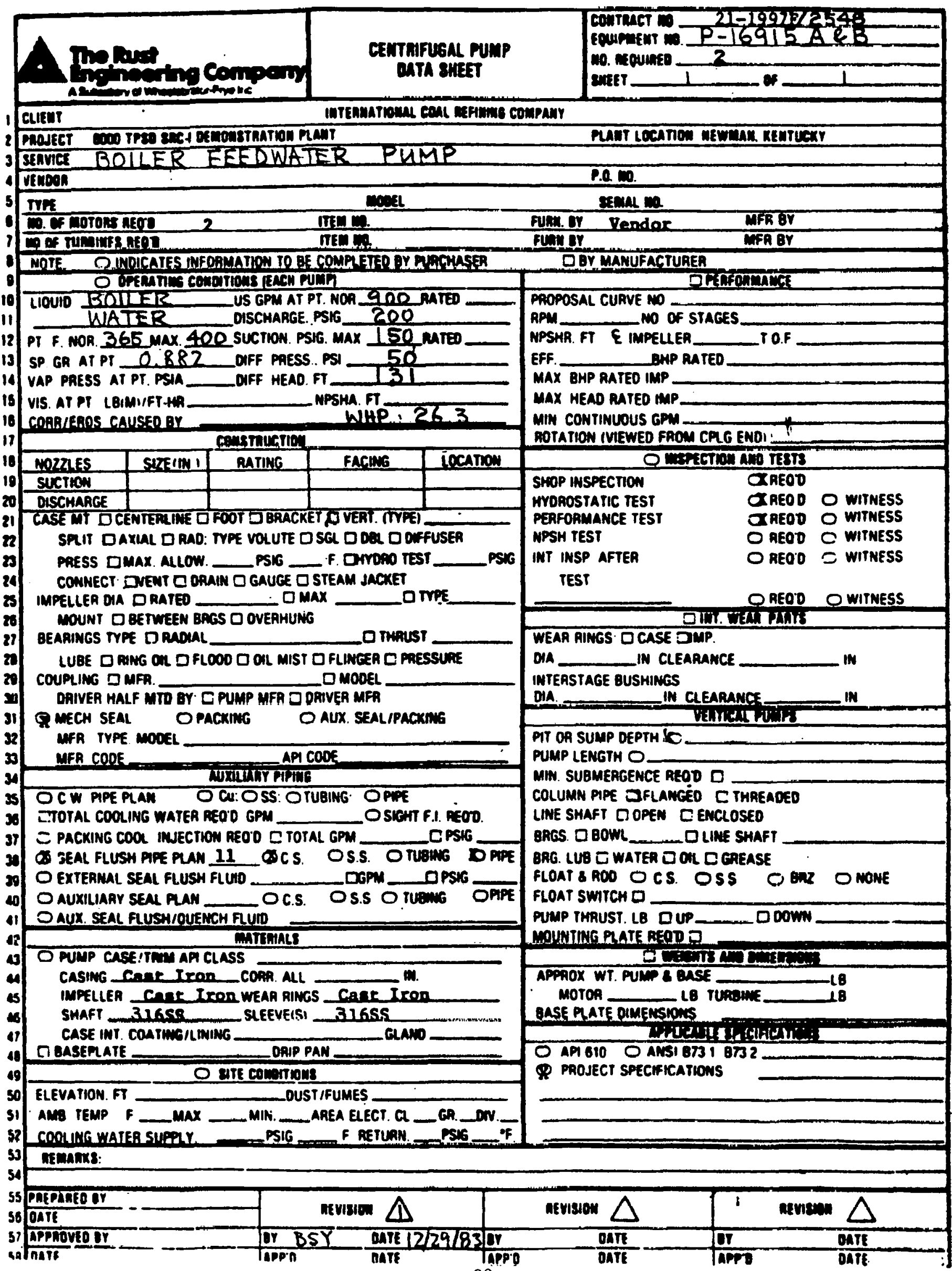


CENThIFUBAL PUAAP BATA BHEET
표

Co. Of morons meOP

Dof rugares aeO2

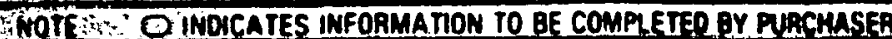

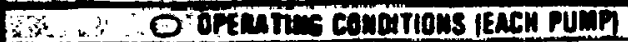

10 L10U10 -SLOP OIL US GPM AT PT NOA 150 AMTED

iii

PI F. MOR. $77 \max \frac{150}{15}$ SUCTION. PSIG. MAX $\frac{0}{50} 0^{\text {AMTEO }}$
SP GP AT PT 1.0 OIFF PRESS. PSI

SP GA AT PT - 1. O

ic VAP PAESS AT PT. PSAA

is VIS. AT PI LBMMIFT HA

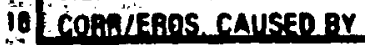

ii

in monates

is

OASCHARGE

OIFF PRESS.. PSI DIFF HEAD. FT MPSHA. FT WHP: 4.39 constnuction

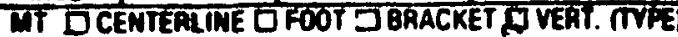
SAII DAXIAL DAAD: TYPE VOLUTE $\square$ SGL D DEL D DIFFUSER

\section{0}

30 DAIVER MALF MTD

31

32 MFA . TYPE MOOCL

33 . MFA CODE

34

25

OCW PIPE PLAN

F. OUYMONO TEST

COMNECT DNEWI C DRAIN D GAUGE D STEAM JACKET

IMPELLER DIA D RATED — ¿ MAX 口TYPE MOUNIT D BETWEEM BRGS D OVERHUNG

OEARINGS TYPE D RAOHAL

D THAUST

LUBE D RING OU DFLOOD O OLL MIST DFLINGER C PAESSURE

COUPLIMG DMFR. O MOOEL

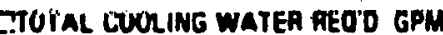
AUxILAT PITI:

W WECTION PEO'D OTOTAL GPM

OAPE

33. $\$$ SEAL FLUSH PIFE PLAN 11 CS. OS.S. O TUBIIOS DPPPE

39. O ExTERMAL SEAL FLUSH FiUIO

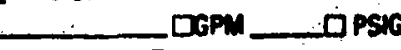

40 O AUXULARY SEML PLAN OC.s. OS.S O TUBAMG OPIPE

1 SAUX. SEAL FLUSHIOUENCH FLUID

42

4

4

4

48

49

30)

31

34

55 PIITITES or

S6) OAfE

si approvero or

silnits

PLMP CASE!TREM API CLASS MATERIAL

Casing cast Iron CORA ALL

IMPELLER Cast Iron WEAR AINGS Cagt Iron

SMAFT 3165S SLEEVE(S) $3265 S$

CASE INT. COATHO/LINING

CiBASEPLATE

$\dot{2}$

gite compirnome

GLAhD

ELVATIOA FI$$
\text { ren }
$$

DIIST/FIMFS

AMO TELP $F$

$\max$ Mik. osio Pasing

Punn. or

PLAMT LCCANDO OEWHAK. KENTUCKY

contract n. 24-10978/2545

Evirnewr $P-16918 A B$

Mo. nequipen

EMEET

P.o. 10

Sental ia

Fume ar

D OY MANUFACTUAER

PAOPOSAL CUAVE NO

APM _ MO OF STAGES

NPSHR. FT : E IMPELLER_T.O.F

EFF. BHP RATEO

MAX. BHP RATED IMPP

MAX HEAD RATED IMP

MIN CONTINUOUS GPAM

ROTATTON IVIEWEO FROM CPLG ENDI -

SHOP INSPECTION

O mateTion aWn $\mathrm{r}$.

HYDROSTATIC TEST

PERFORMANCE TEST

QXne00

NPSH TEST

CAEO D O WITNESS

NT INSP AFTER

OTREOD $O$ WITNESS

TEST

O REOD O WITMESS

$O$ REOO $=$ WITMESS

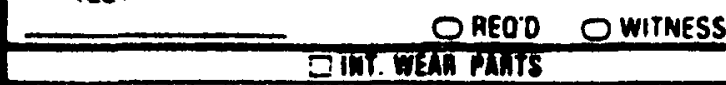

\section{WEAR RINGS DCASE DMP.}

DIA _ IN CLEARANCE ___ IN

INTERSTAGE BUSHINGS

OIA. IN CLEARAMCE___ IN

PIT OR SUMP OEPTH $\mathrm{L}$

PUMP LENGTH $O$

MIN. SUBMERGENCE REOD D

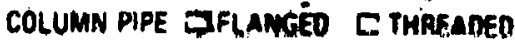

LINE SHAFT DIOPEN C ENCLOSED

BRGS. D BOWL _ $\square$ LINE SHAFT

BRG. LUB $匚$ WATER D OU L GAEASE

FLOAT 6 ROO OCS. OSS O BAZ ONONE

FLOAT SWITCH D

PUMP THAUST. LQ LT UP ODOWN

MOUNTING PLATE REOOD

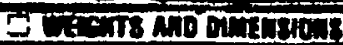

APPAOX WT. PUMP S RAS

notoh L L TUABINE _... LE

BASE PLATE DIMENSIOAS

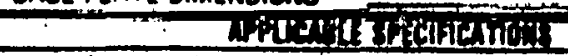

O API 610 O ANSI BȚ 1. BT32

P PROJECT SPECIFICATIOMS 


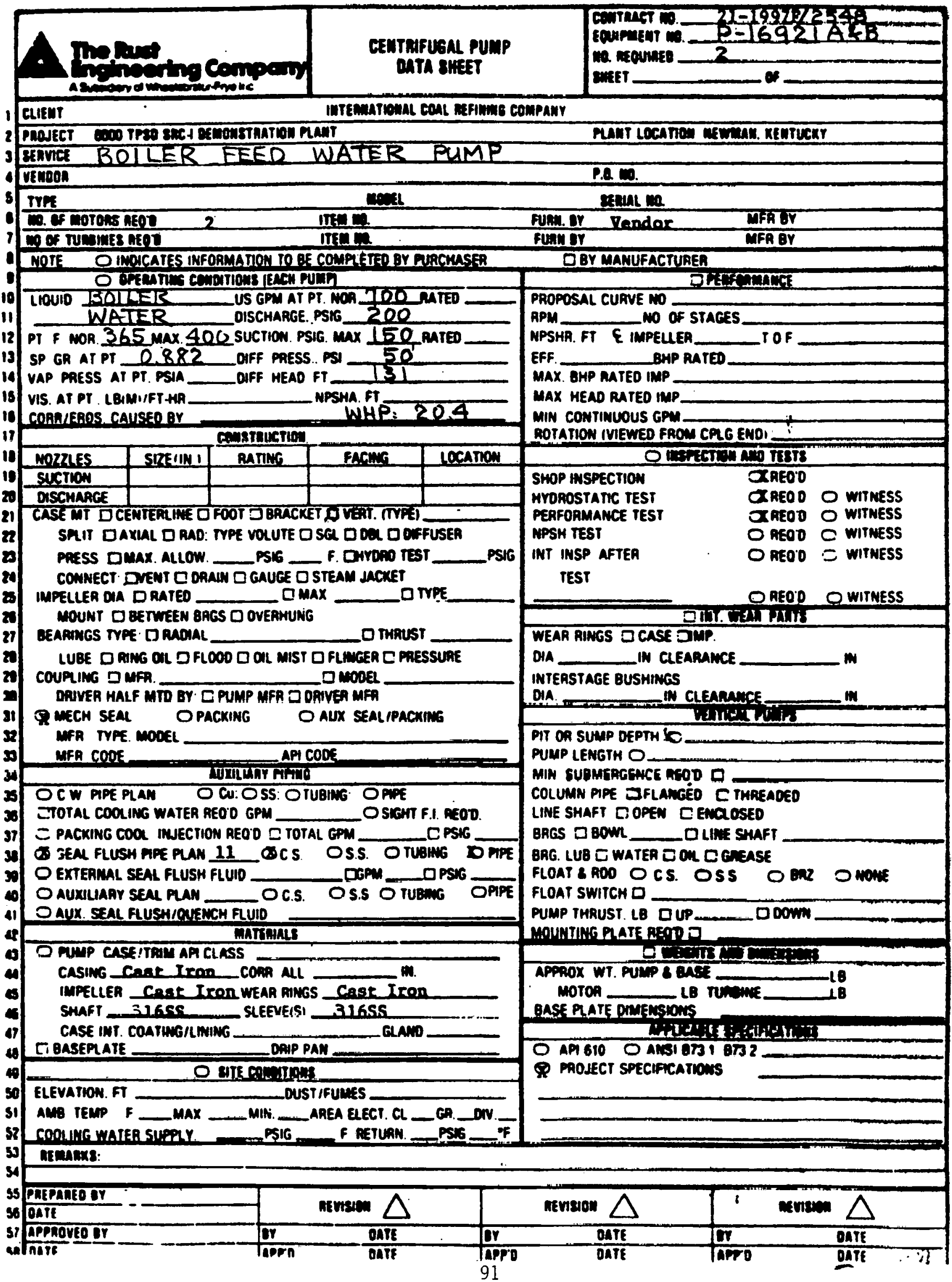




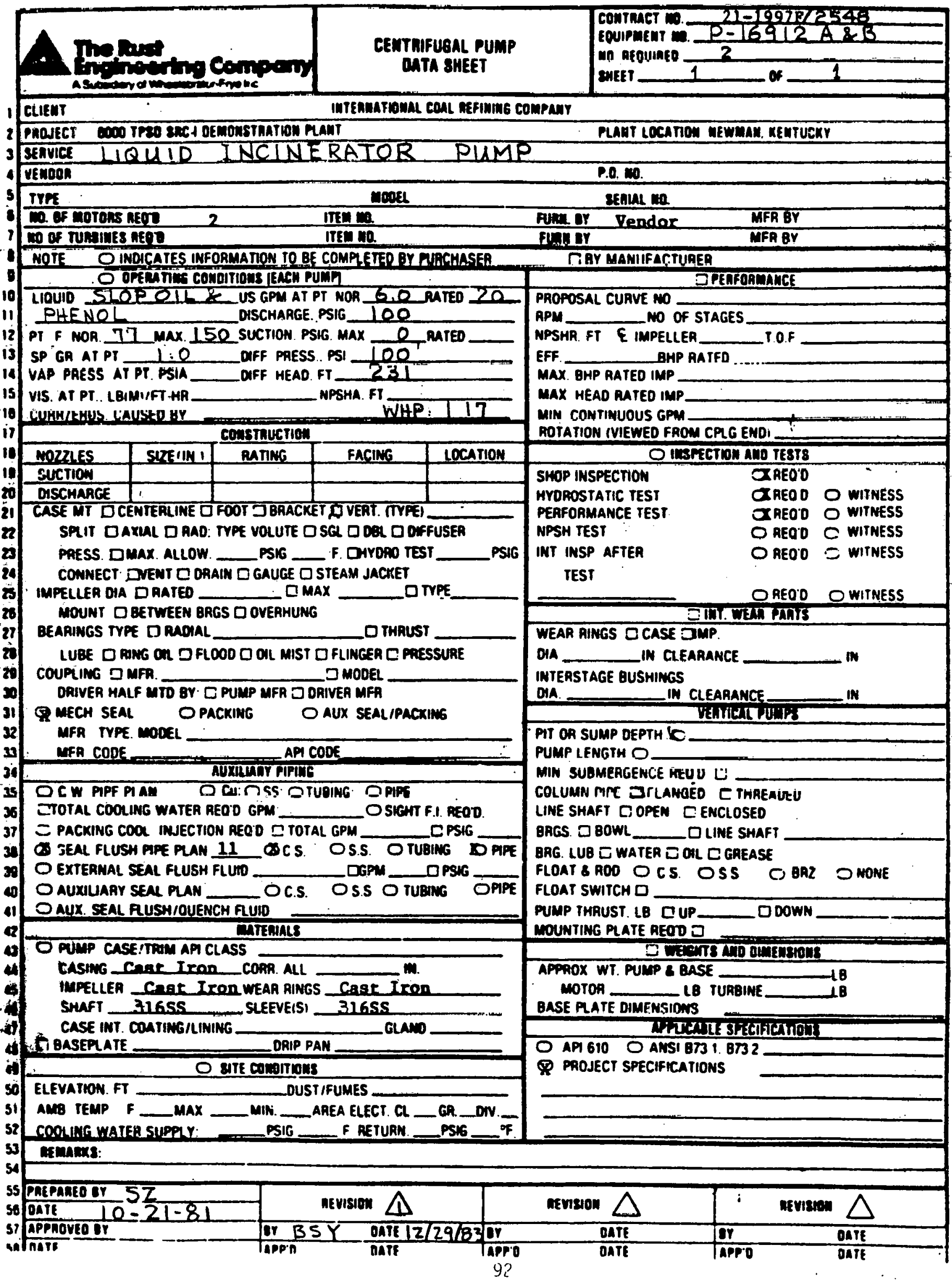




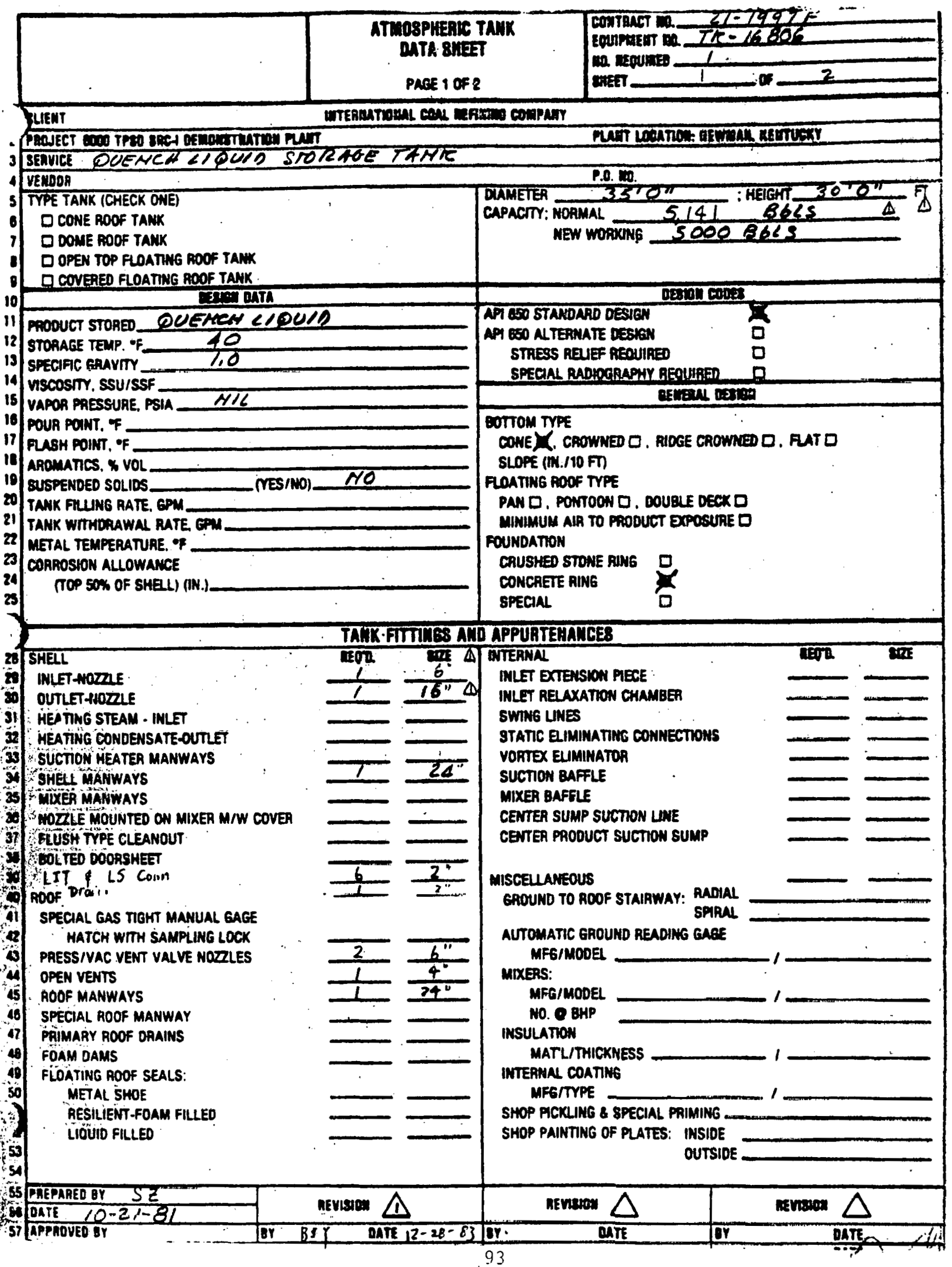




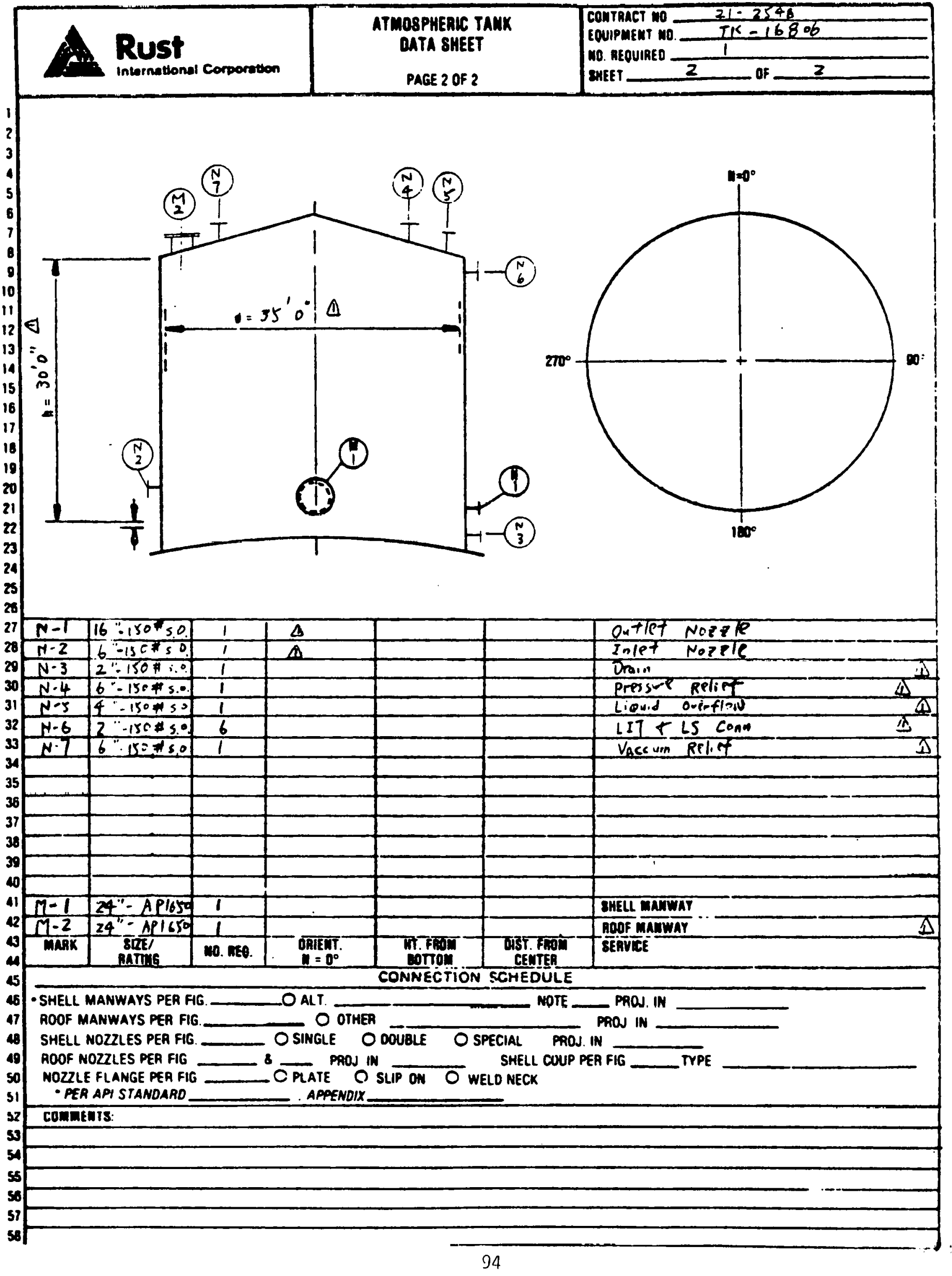




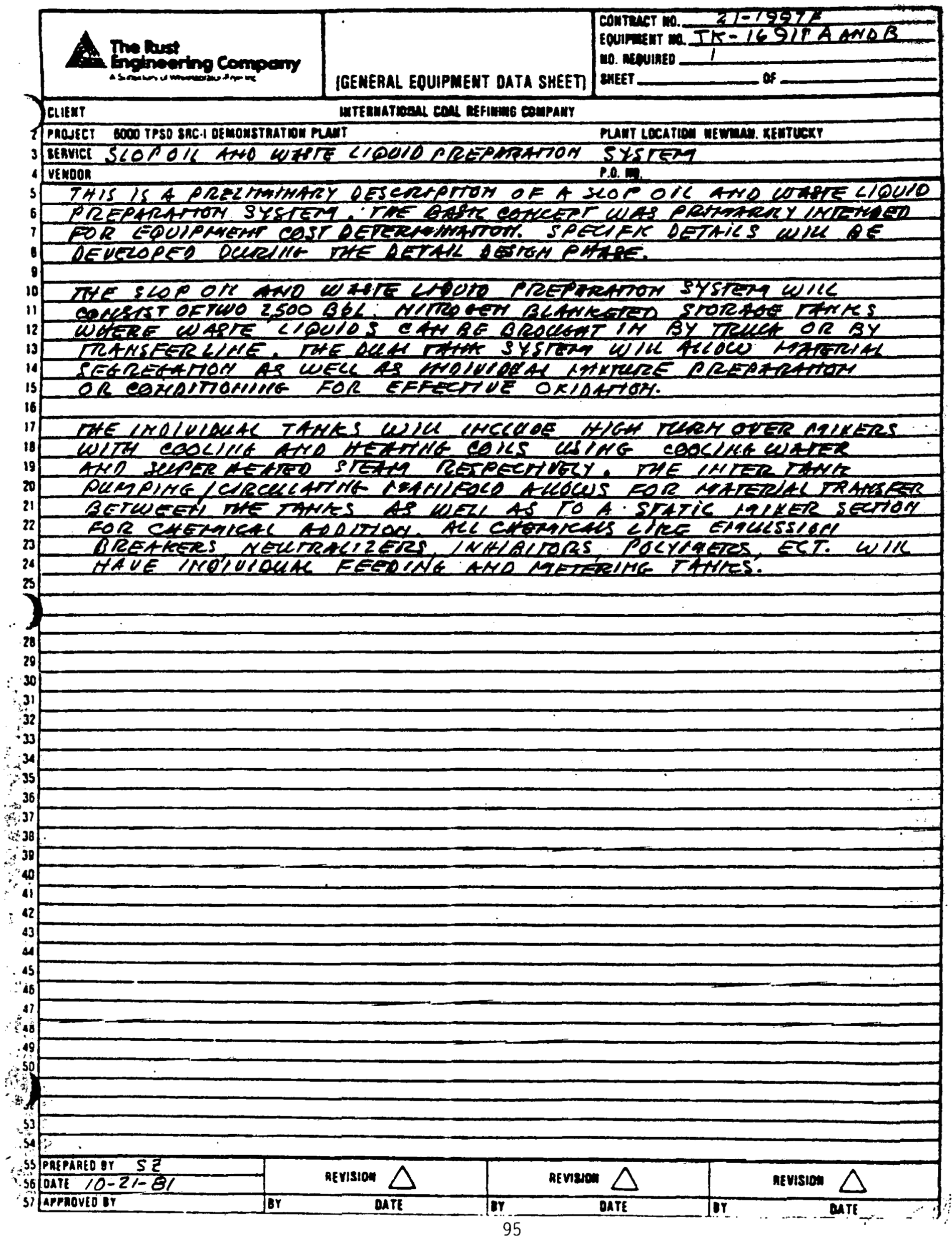




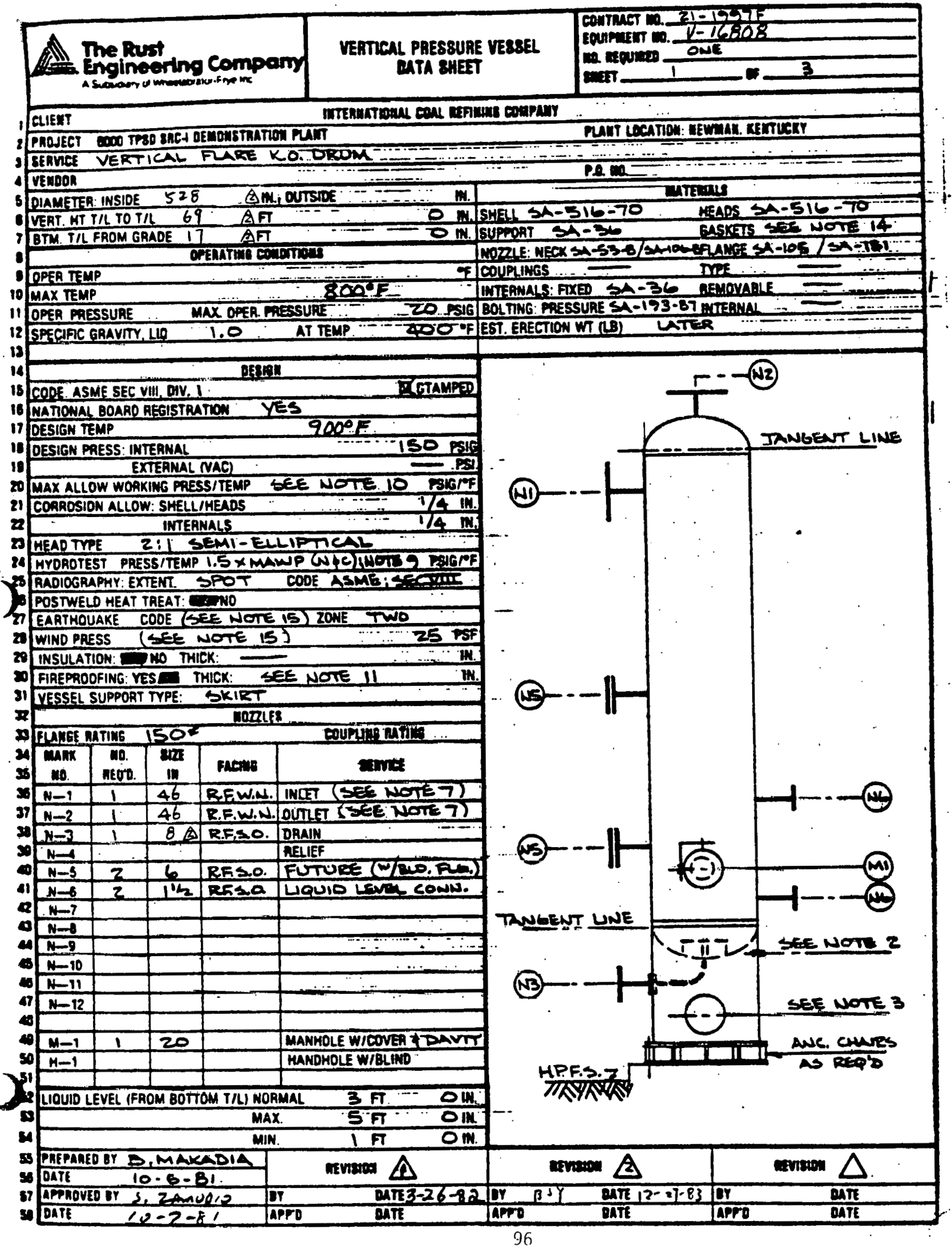


1 CIENT INTERNATIONAL COAL SFINING COMPNY

A.0nise

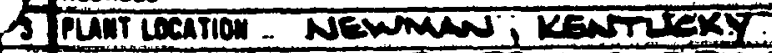

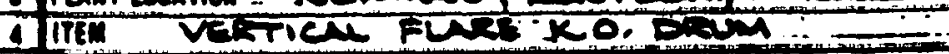

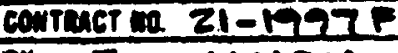

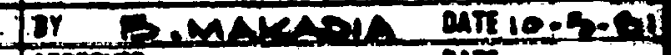

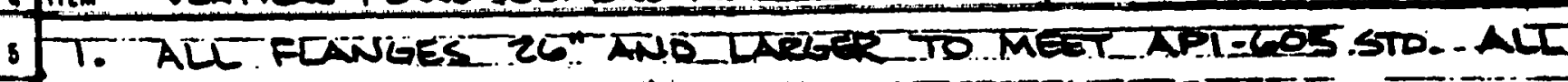

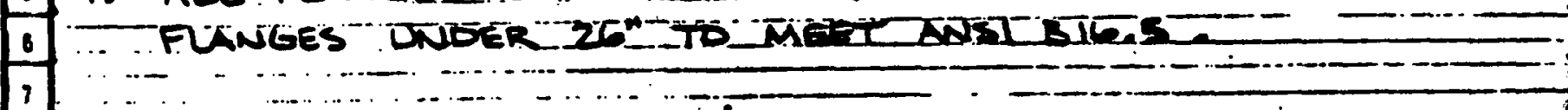

- 2. SRIRT VENT.. (I REQÜIREO). TO. BE A. 4"-LCH 40. PIPE SLESVE,

LOCATE AS HILH AS POSSIBLE. ON SKIET.

3. SKIRT ACCESS OPENING" (I REQUIRED) TO EE 20 " NOM.dIA.

4. ALL NOZZLES TO BE REINFORCED AS REQUIRED. PER THE

- A.SME. CODE, SEETION JUIR DIVISION I..

5. ALL NOZZLES to HAVE A $6 "$ MIN. CENTERLNE PROJECTION

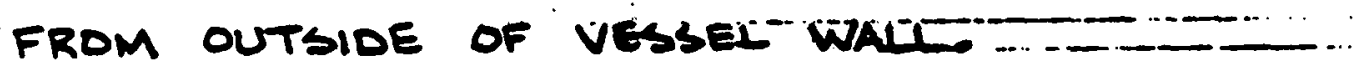

6. O.D. OF SKIRT SHALL MATCH -0.5. OF VESSEL. SUPPLIER. SHALL FURNISH THE SKIRT AND BASE R. THICKNESS AND ANCHOR BOLT DESILN CALCHATIONS... THE SKIRT SHALL BE 3/8" MINIMUM" THATCKNESS.

7. SUPPLER SHAL DESVEN A. FURNISH IWO_LIFTING LUGS.

8. SUPPLIER SHALL FUENMSH TWO ELECTRICAL GROUNOWG CLIPS.

9. SUPPLIER SHAL CALCUATE THE MAWP, NEW AWO COLD, USING AS BUILT THICKNESSES. SHOP HYOROTEST PRESSURE SHAL 1.5 TIMES THINIMUM OF MAWP." THE LIMITING "COMPONENT" SHAL BE SPECIFIEO ON THE DRANING.

\begin{tabular}{|c|c|c|c|c|c|c|c|}
\hline 40 & 4.0 & Mnsion & in & $\operatorname{con}$ & $\mathbf{m}$ & un & nen \\
\hline 11 & & & & & & & \\
\hline 12 & . & & & & & & 20 \\
\hline
\end{tabular}




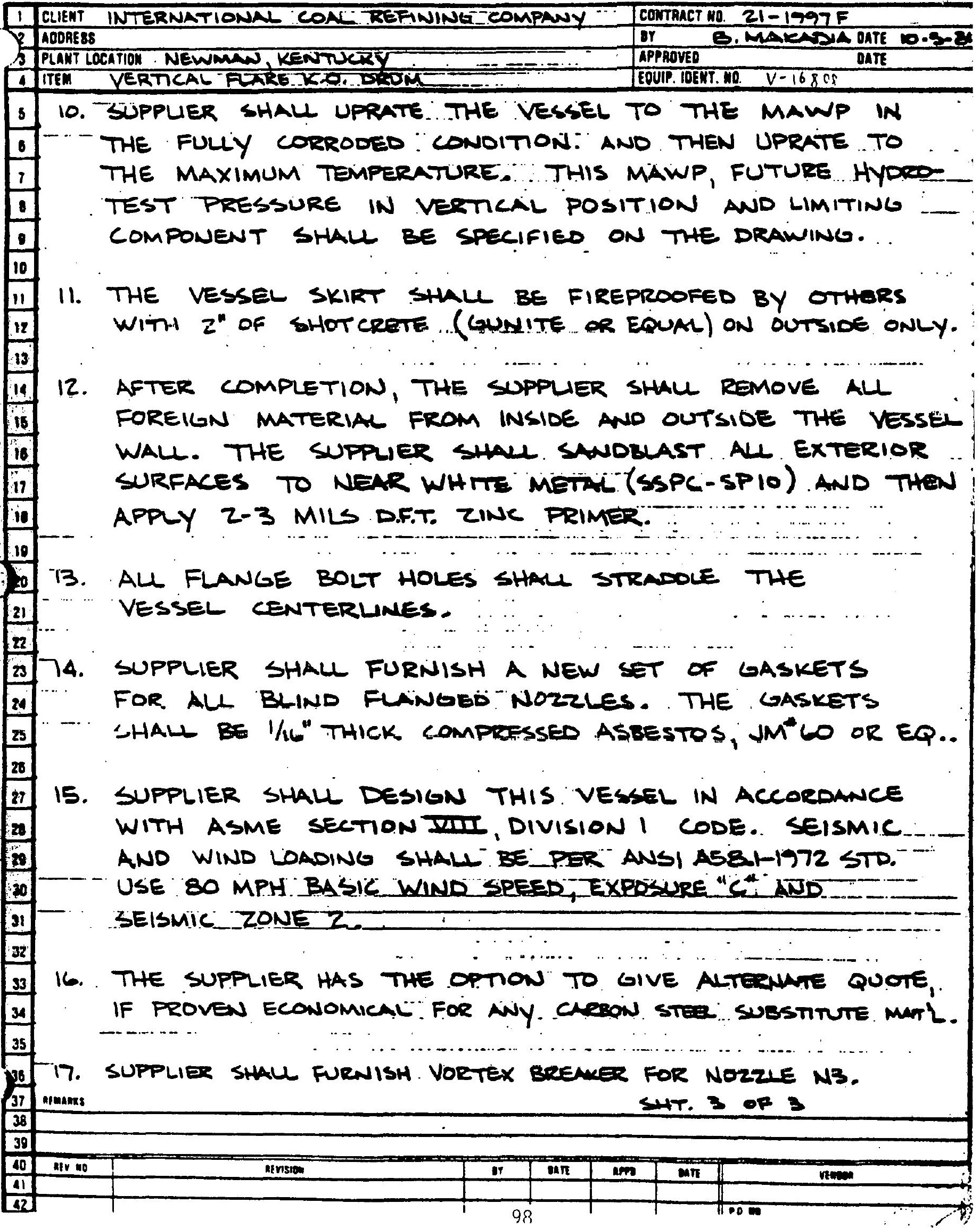




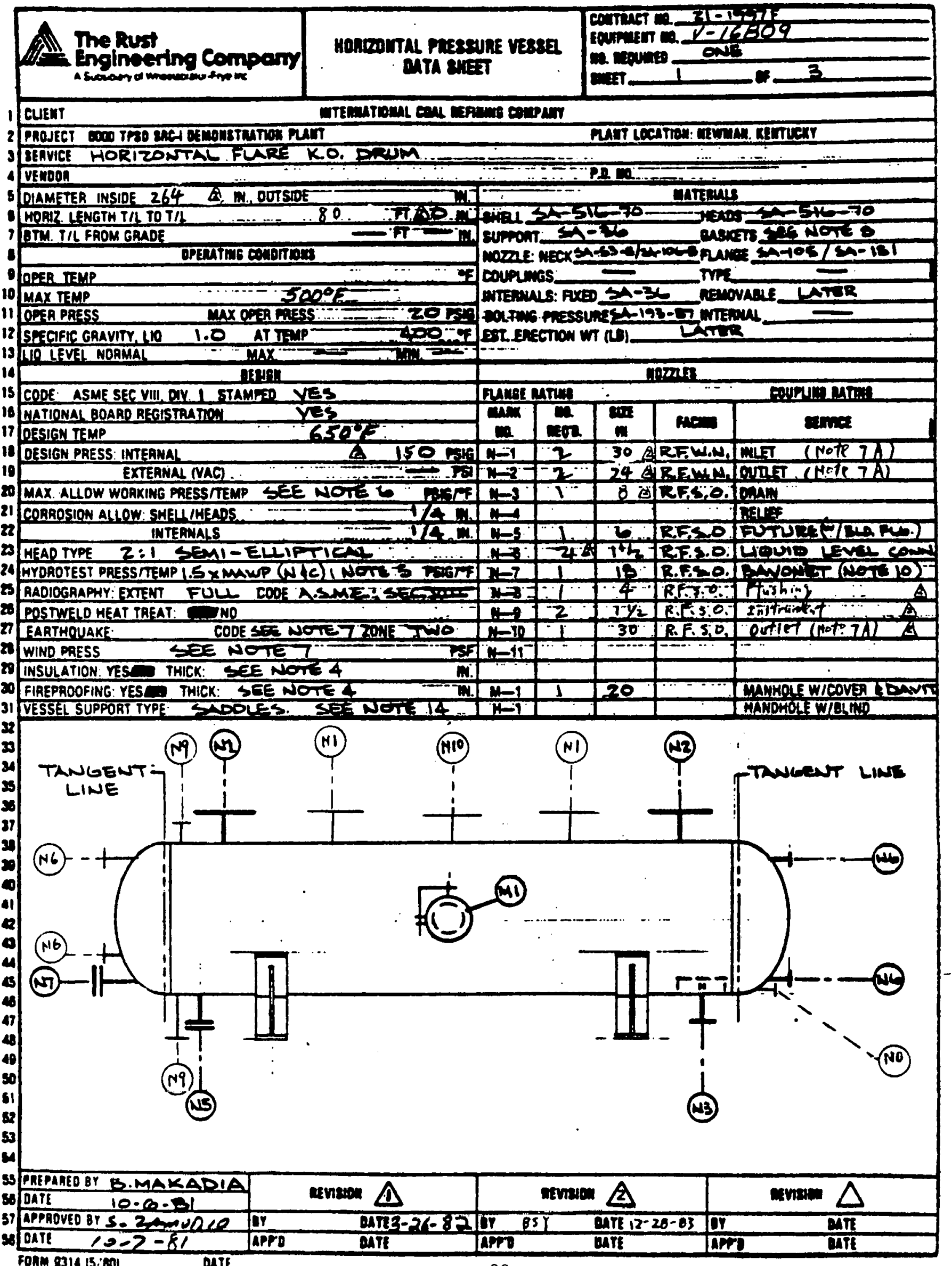

FOAM 8314 $13 ; 001$ DATE 99 


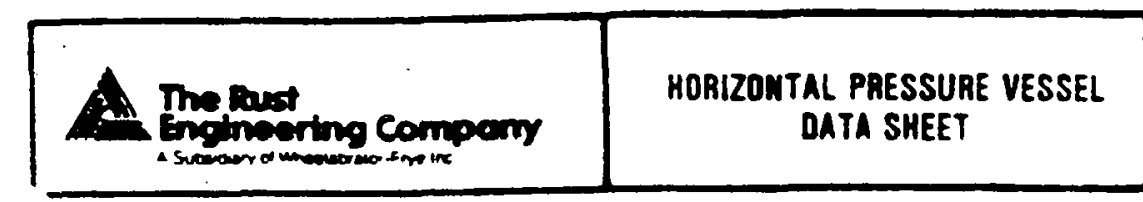

LIENT

$$
\text { LIENT }
$$

InTERMATDEAL COAL REFIMING COMPANY

2) PROJECT 6000 TPSO SAC-I DEMONSTRATION PLAM

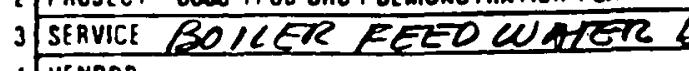

VENOOR

5 OIAME TER INSIOE

IN OUTSIDE

5 HORIZ LENGTH T/L TO T/L

7 BTM TIL FROM GRADE

8

9 OPER TEMP

10 MAX TEMP

11 OPER PRESS

SS

OPERATING COMOITIONS

17 SPECIFIC GRAVITY LIO AT TEMP

13 LIO LEVEL NORMAL

14

15 CODE ASME SEC VIII. DIV STA

17 DESIGN TEMP

18 DESIGN PAESS INIERNAL

19 EXIERNAL IVAC

20 MAX ALLOW WORKING PRESS/TEMP

21 CORR ALLOW SHELLIHEAOS

22 SHELL

23 HEAD IYPE

24 HYDROTESI PRESS I IEMP

25 RADIOGRAPHY EXIENI 'OSIWEL [I HEAI IAEAI YESINO

28 WIND PRESS

29 INSULAIION YESINO THICK

30 FIREPROOFING YESINO THICK

31 VESSEL SUPPORT TYPE

3? EKETCH

33

34

35

36

37

38

39

40

41

43

$\Delta$

45

47

48

49
$\operatorname{sn}$

(3)

$5 S$ PREPAREO BY $S 2$

56 Datl $10-21-9$

$5 7 \longdiv { A P P A O V E O ~ B Y Y }$

SB DATE

ingu 071: 10.phi

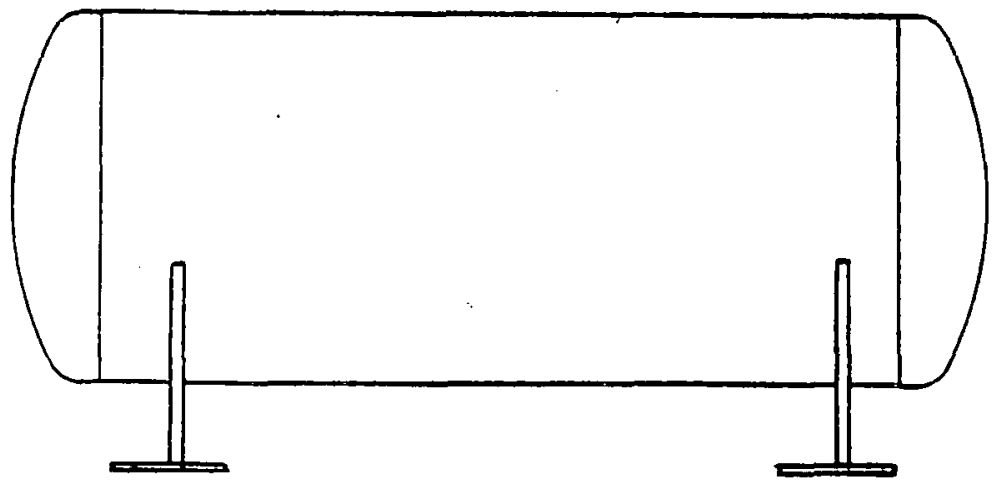

MO. REOUIREO

SHEET P.0. $m$
IN.

IN. SHELL

IN. SUPPORT

NOZZLE: NECK

F COUPLINGS

F INTERNALS FIXED

PSIG $B O^{-}$- YG PRESSURE

F) ${ }_{0} 8$ ?TION WT (LB)
DESINA

MIN
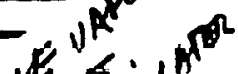

IN. $N-6$

PSIGI F $\mathrm{N}-7$

$-10 k$

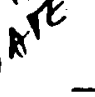
CODE

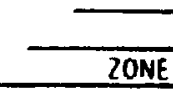

2ONE

\begin{tabular}{r|c} 
& $N-8$ \\
\hline & $N-9$ \\
\hline PSF & $N-10$ \\
\hline IN. & \\
\hline IN. & $M-1$ \\
\hline & $H-1$
\end{tabular}

$\mathrm{H}-1$

CONTAACT Mo. 27-24977

EQUIPUE RT nO. $1 / 16520$

OF

PLAMT LOCATION MEWMAN. KENTUCKY

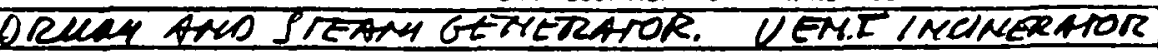

MATERIALS

HEADS

GASKETS

FLANGE

TYPE

REMOVABLE

INTERNAL

COUPLING RATING

SFRUICE

NLET

OUTLE I

DRAIN

RELIEF

MANHOLE W/COVER

HANDHOLE W/BLIND 


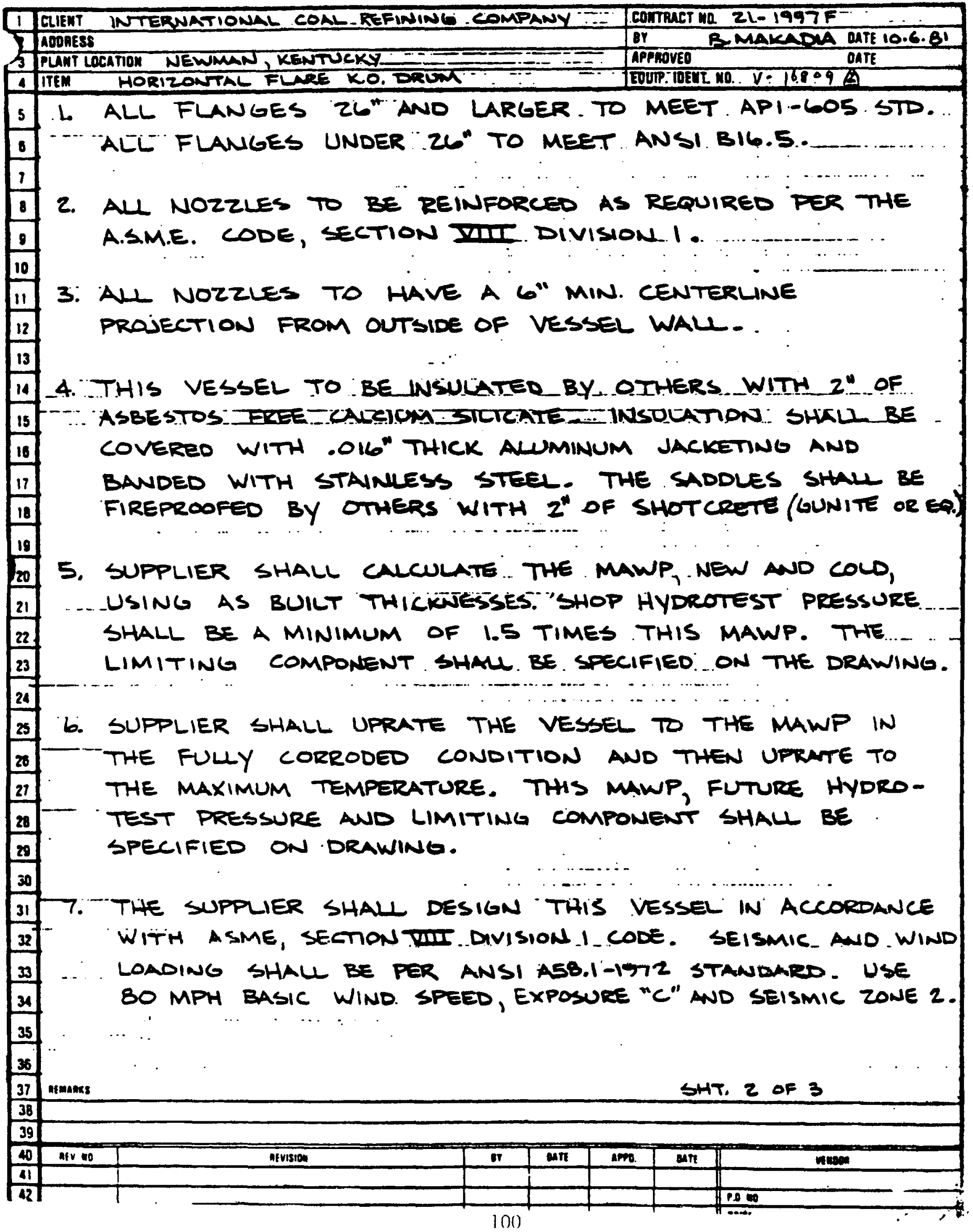




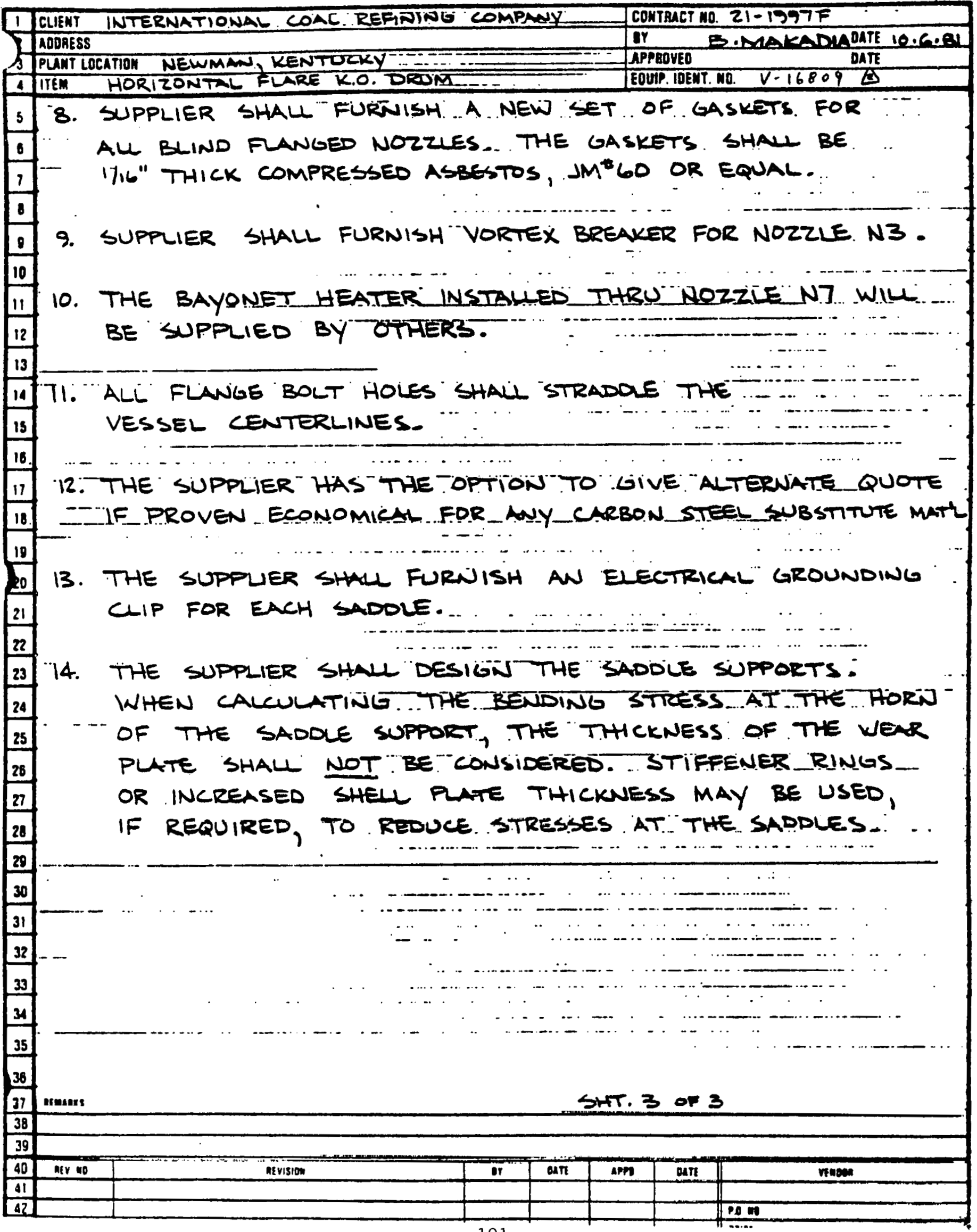




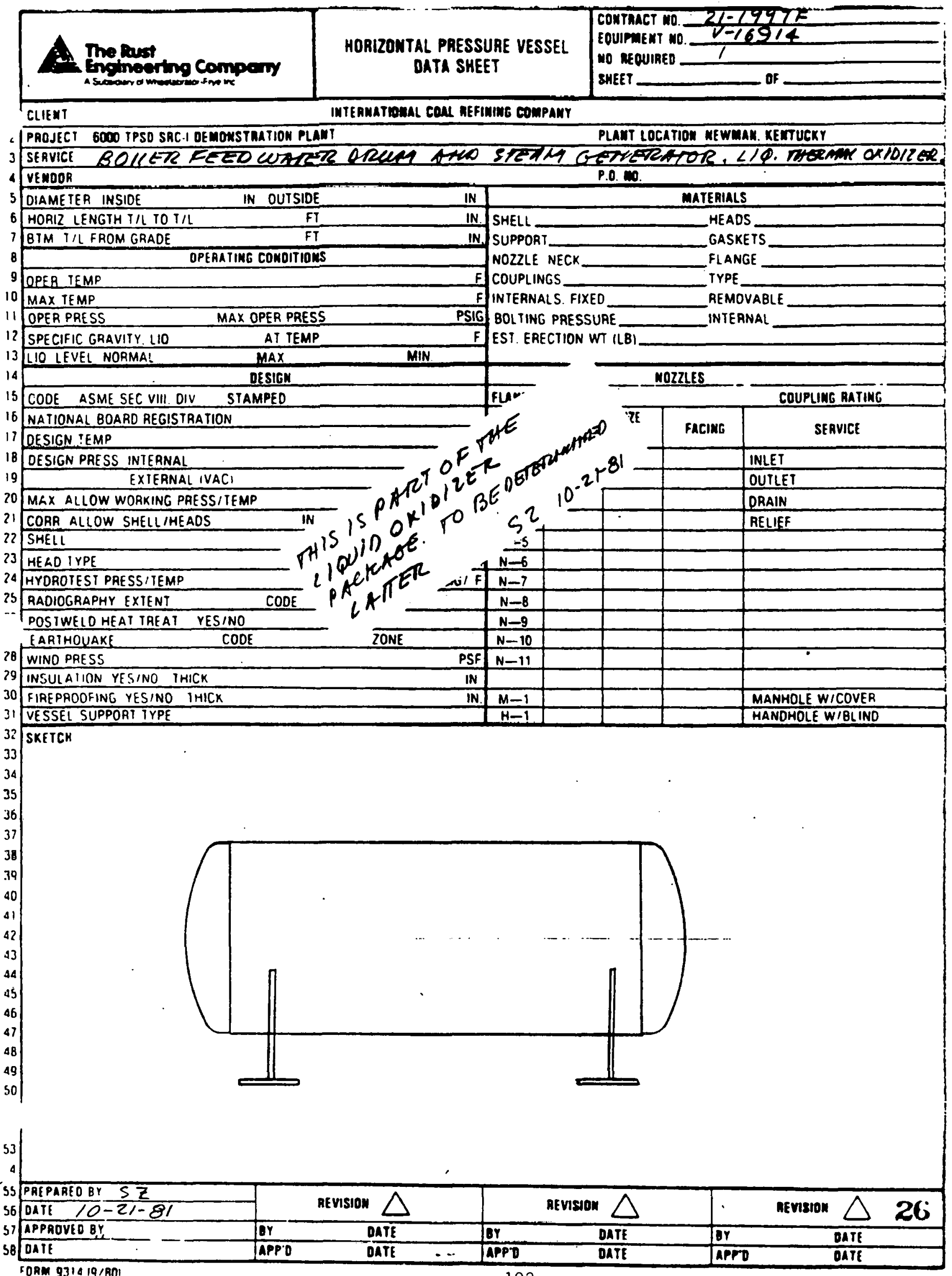




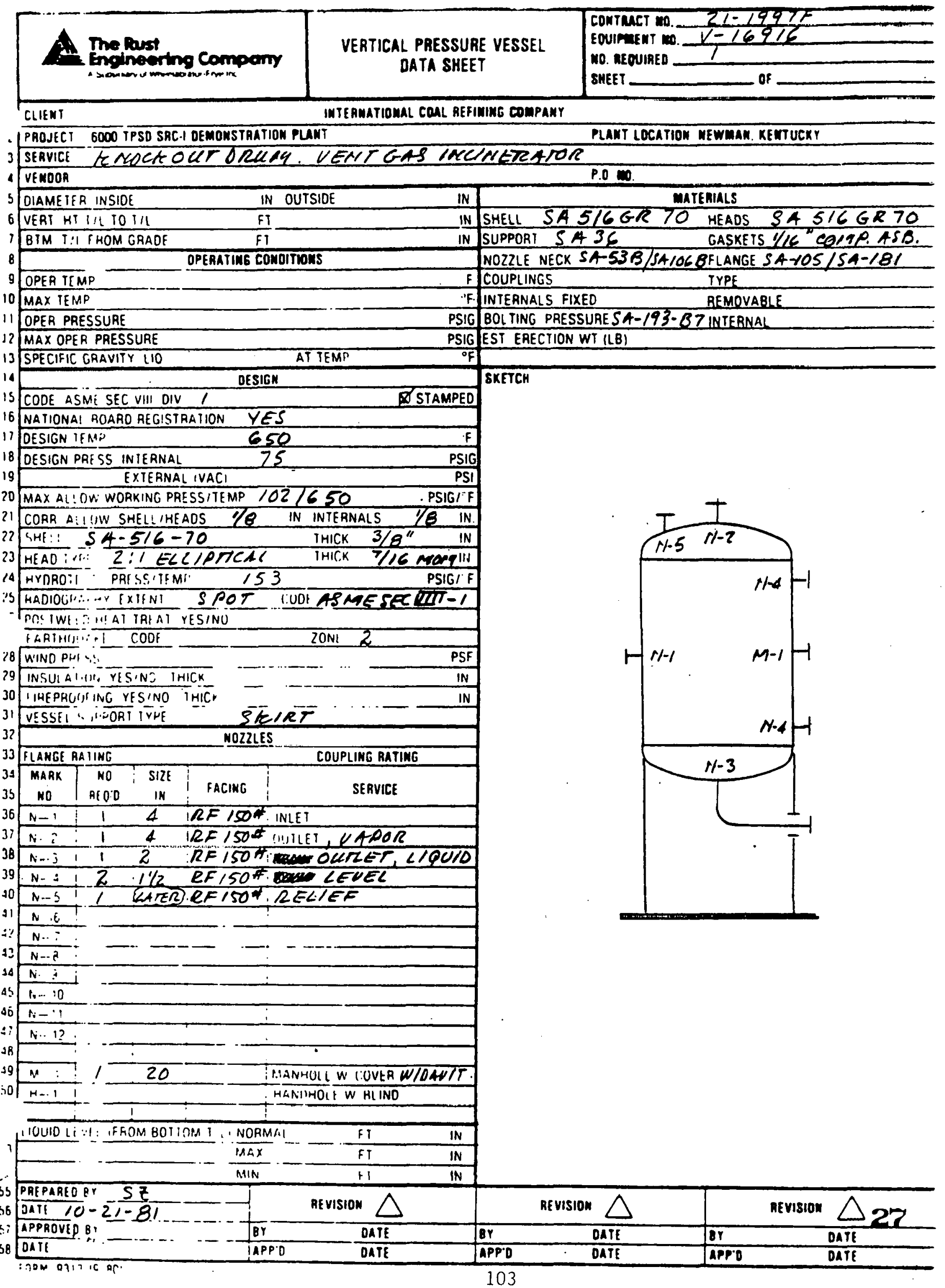




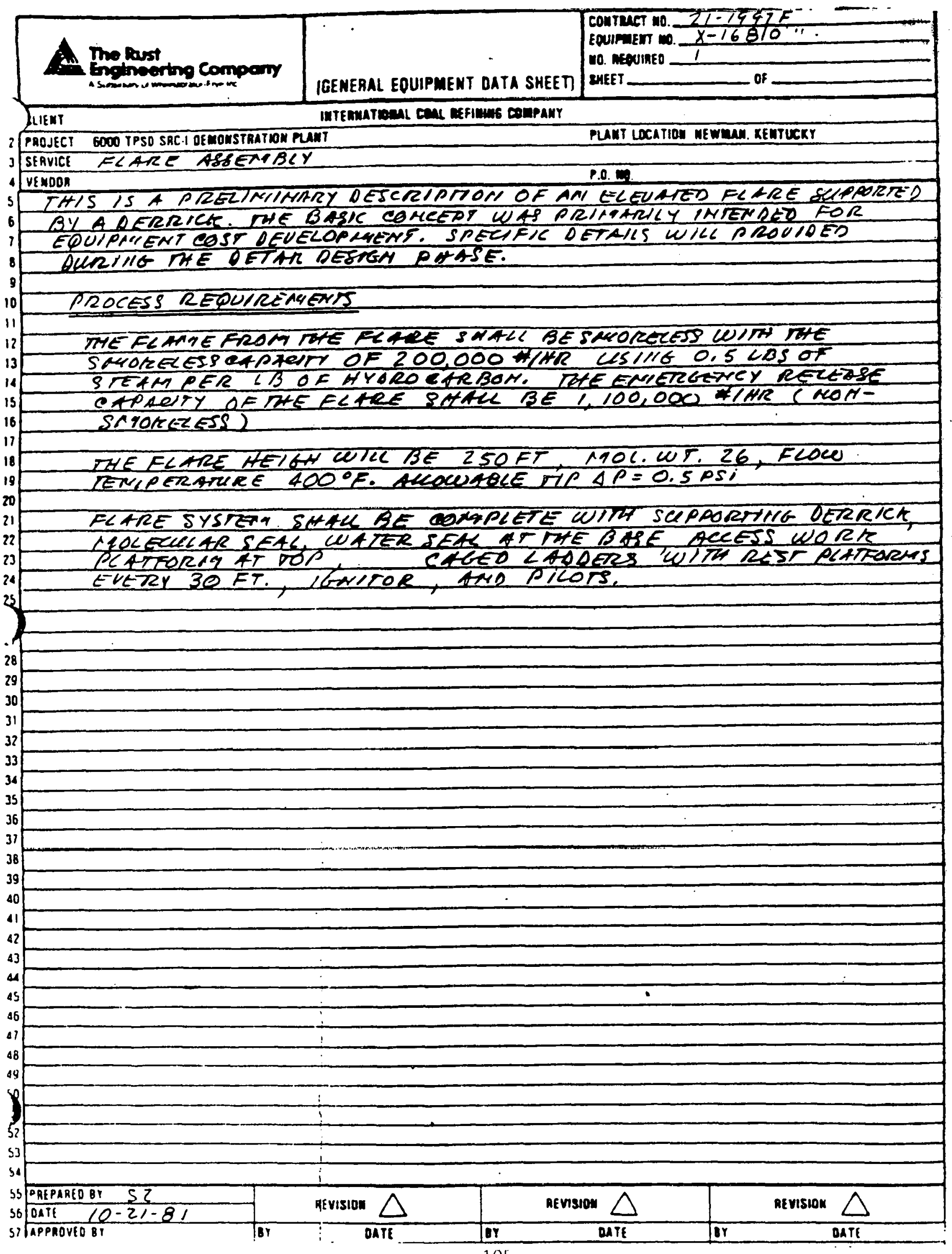




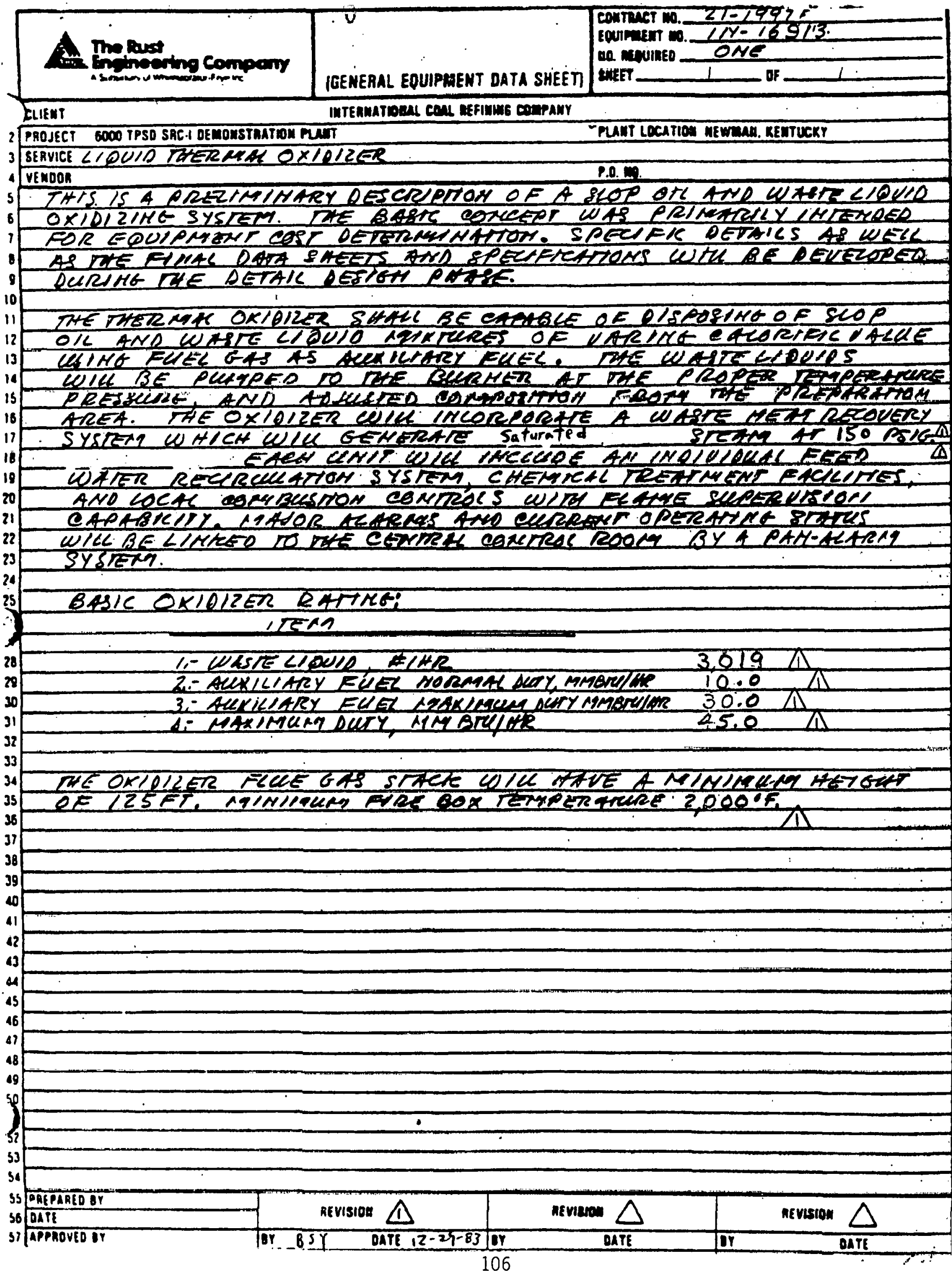




\section{A molous}

elent

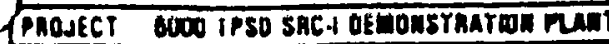

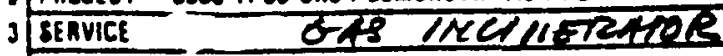

4 VEMOOR

IGENERAL EQUIPMENT DATA SKEET

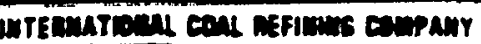

coiriviet no. $2 /-19.7 \cdot 15^{\circ}$

Eonnewit m. $1 N-16919$

Ma. Mevimeo.

EIEST

1

of

PLAMT LOCATIOA MEWEMT RETTUCKY

P.0. 1.

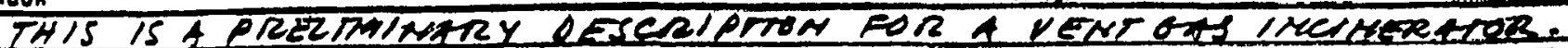

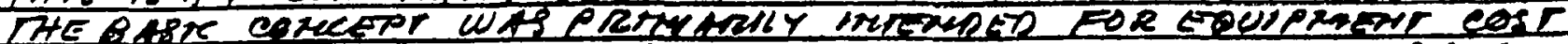

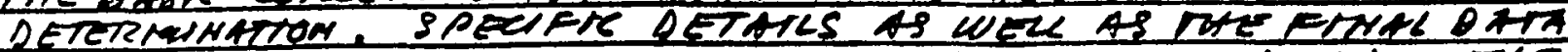

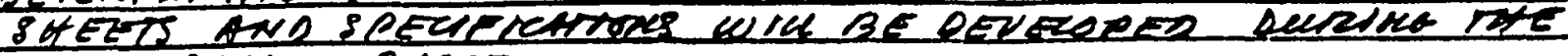

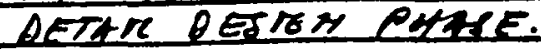

10

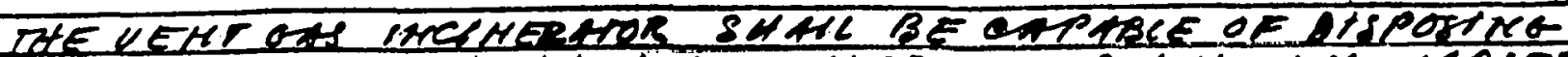

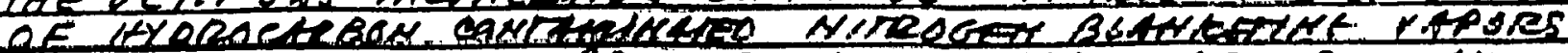

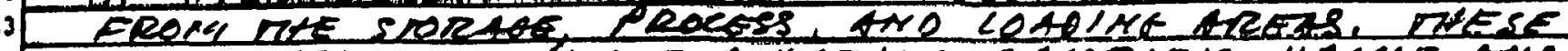

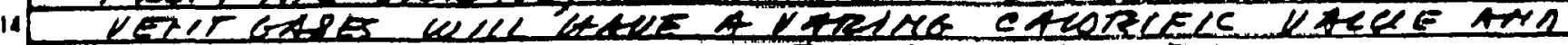

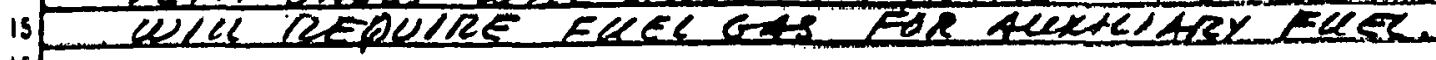

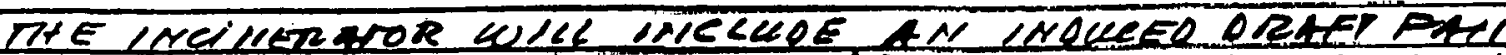

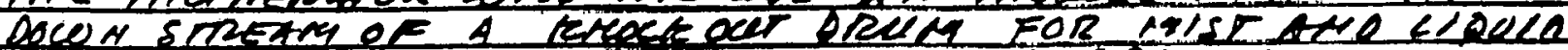

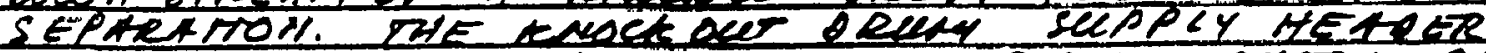

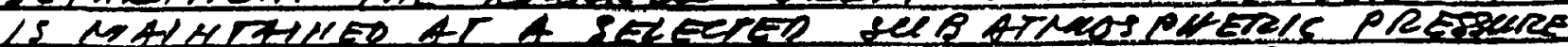

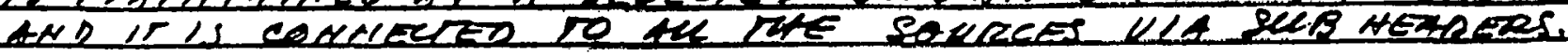

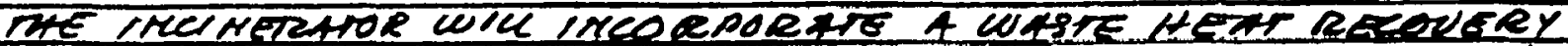

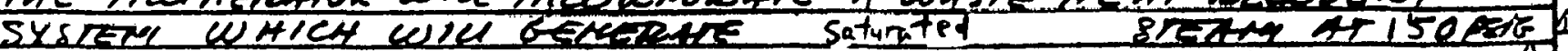

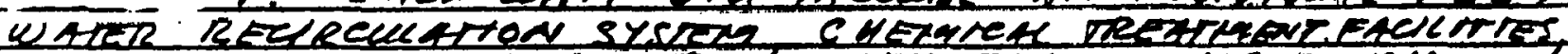

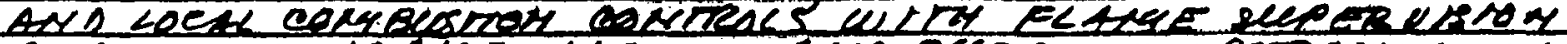

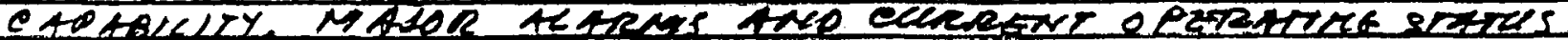

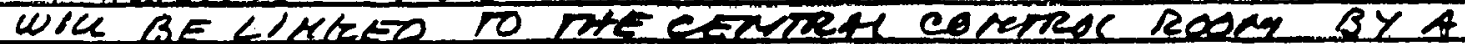

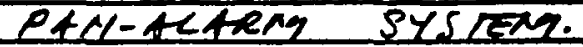

\section{QASIC OXIDIRER RATRG:}

\section{TrM}

34

nevisom $\triangle$

Quif nate 107

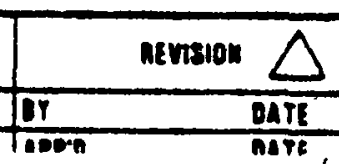




\subsubsection{Fuels}

\subsubsection{0\%1 System Description}

Plant fuels, which include fuel o1l, plant generated gaseous fuel, excess plant generated hydrogen, and LPG are distributed to the various area contractors as required. Separate piping system headers are provided for gaseous and liquid fuels.

\subsubsection{Utilty Flow Dlagrams}

Refer to the following drawings included with Interconnecting Systems, Paragraph 2.3.

00-16-03010 Interconnecting Piping System, Fuel Gas, Hydrogen \& LPG 00-16-03011 Interconnecting P1ping System, Fuel 011 


\subsection{INTERCONNECTING SYSTEMS}

\subsubsection{Facilities Description}

2.3.1.1 The interconnecting system will consist of a structurally designed pipe bridge that will be approximately 20 feet wide with a clearance of 30 feet from finish grade at all road and railroad crossings. The bridge will be designed with two and three tiers as required to accommodate the various pipe sizes. All process lines will be located on the 1st tier; steam and condensate lines will be located on the 2nd tier; all other utility lines will be located on the 3rd tier where possible. A 4th tier will be installed, as required, to accommodate all electrical cable: trays and instrumentation lines. The minimum spacing between each tier. will be 6 feet.

\subsubsection{The north-south run of pipe bridge will be installed at} coordinates $N .2000$ by E. 15000 , approximately. The bridge will run north to coordinates N.4850 by E.14300 to the liquid storage area. At this coordinate, the pipe bridge will terminate and all piping will be installed on pipe sleepers for the liquid storage and solids storage (area 11) and coal preparation (area 11).

2.3.1.3 All sleepers will be installed a maximum of 30 inches from finish grade. Any pipe in storage areas that must penetrate a diked area will be installed in a pipe sleeve 2 inches larger. than the carrier pipes, and will be sealed at the end inside. the diked area to prevent leakage from the diked area in case of spillage or rupture of the storage tank.

2.3.1.4 In areas where pipe runs will consist of small diameter pipe, or with only a few lines involved, pipe will be installed on T-pole supports. These T-pole supports will be spaced in a manner to support the smallest diameter pipe in the run. 
2.3.1.5 All T-pole supports will be constructed of round pipe of proper size and will be installed in a concrete footer. The cross members of the $T$-pole supports will be structural steel welded to the pipe.

2.3.1.6 The T-pole supports will be 8 feet wide and the bottom of the cross members will have a clearance of 20 feet from finish grade. Where $T$-pole supports traverse a road or railroad, the bottom of the cross memhers will be 30 feet from finish grade.

2.3.1.7 In areas where two-tier pipe bridges will be used, all process and steam lines (if required) will be installed ull thie first ticr, tho second tier will be used for all other utilities. A third tier will be installed as required to accommodate electrical cable trays and instrumentation. A 6 foot minimum spacing will be maintained between each tier.

2.3.1.8 Provisions will be made for electrical cabie trays and instrumentation on sleepers and $T$-pole supports in liquid and solid storage areas.

2.3.1.8 The strong wastewaters, which consist primarily of ammonia sulfide water, stripper (ASWS) bottoms, GKT blowdown, and hazardous waste landfill leachate will be conveyed in above ground pipes to the strong wastewater treatment system. A single sewer system will be provided to convey weak wastes (contaminated runoff and sanitary waste) to the weak waste treatment system. A ditch system will be provided to collect stormwater from uncurbed areas. 


\subsubsection{A ICRC Interface Integration}

Please refer to the ICRC "Revised Integration Documentation" dated June, 1983, Document No. DOE/OR/03054-24, UC-89. This document defines baseline interface information and complles interconnecting stream information into two categories: the process interface streams and the utilities interface streams. 


\subsubsection{Interconnecting Diagrams}

The following interconnecting diagrams, together with the line calculations summary sheets, are included in this section:

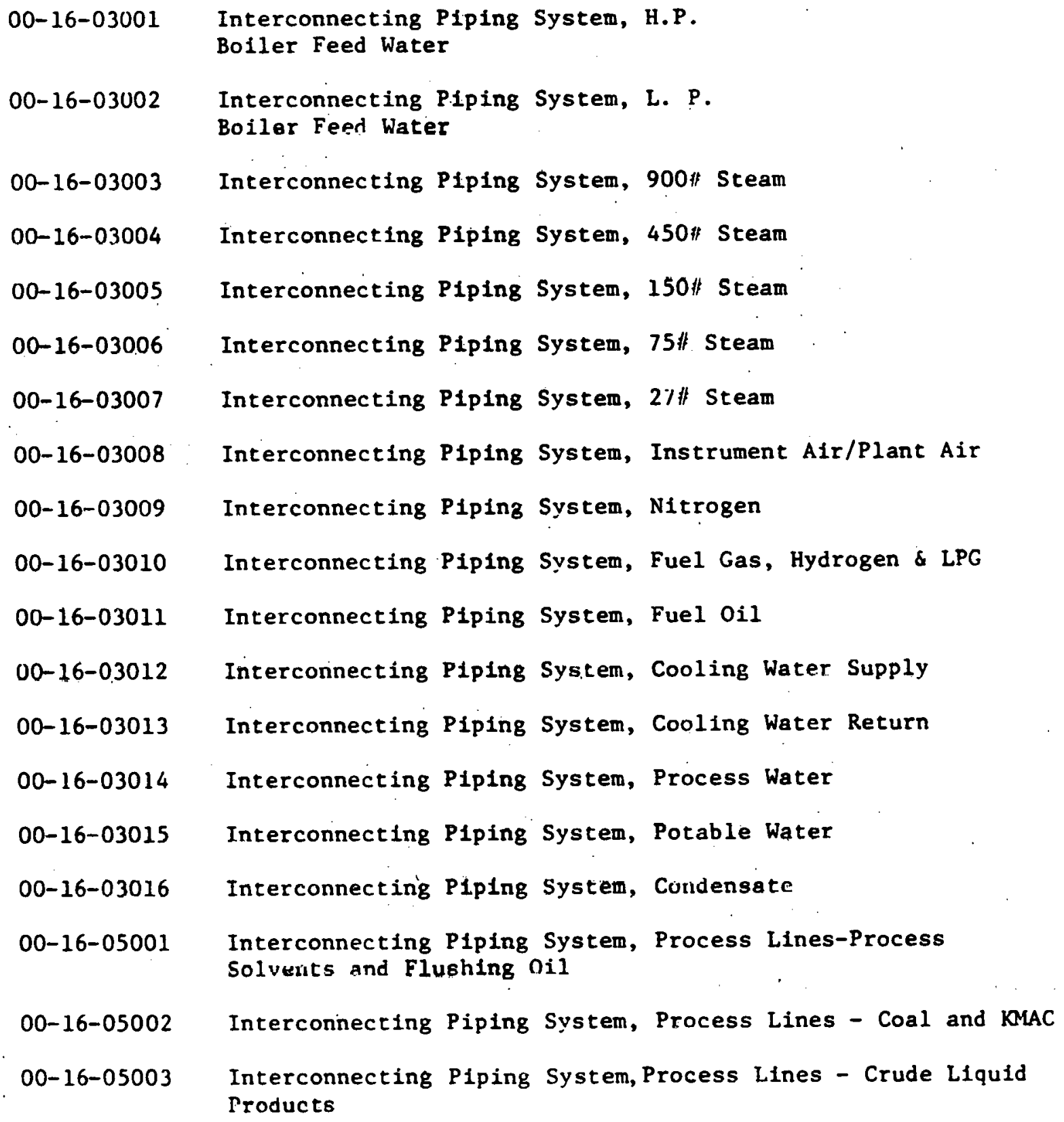




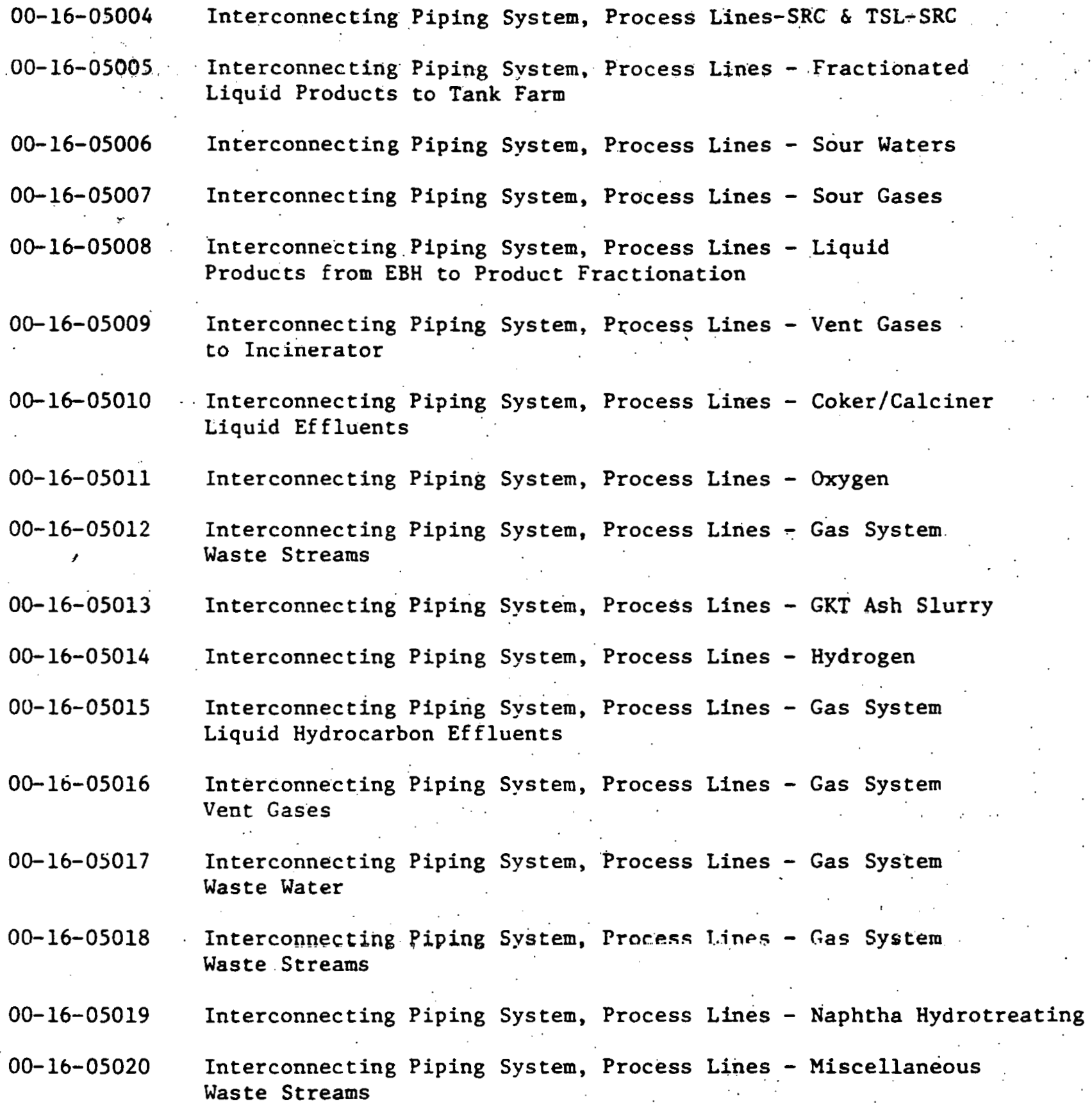




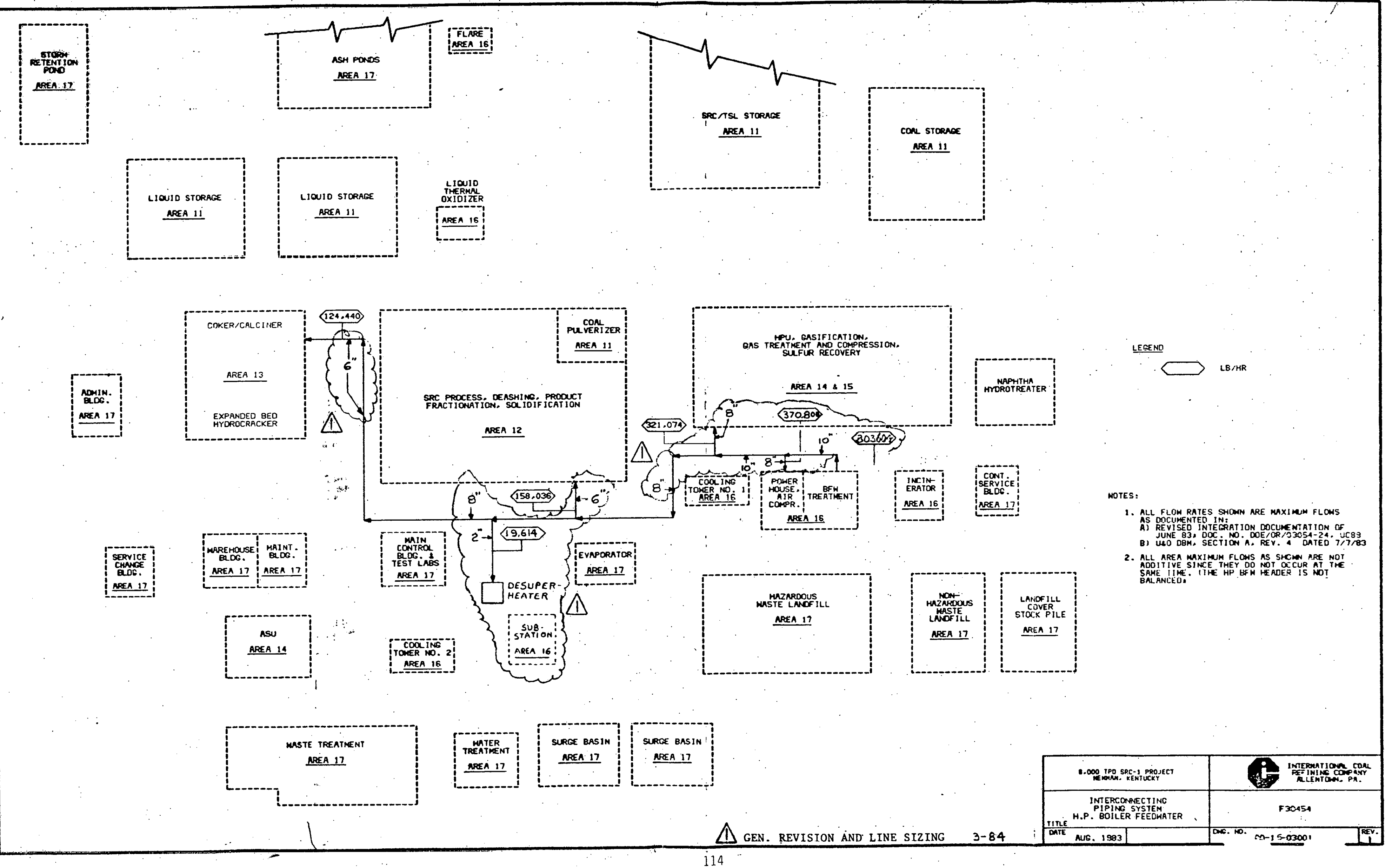




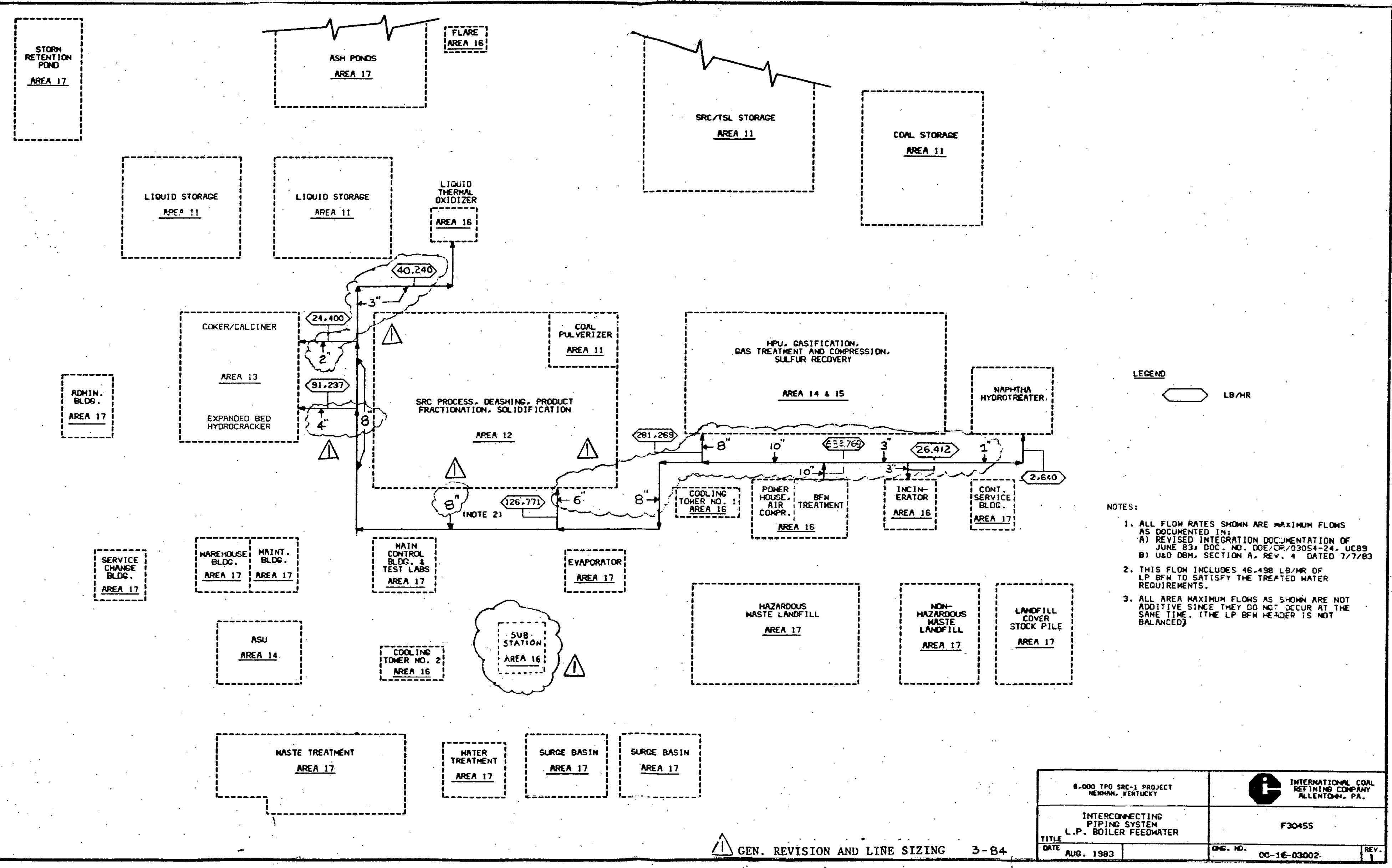




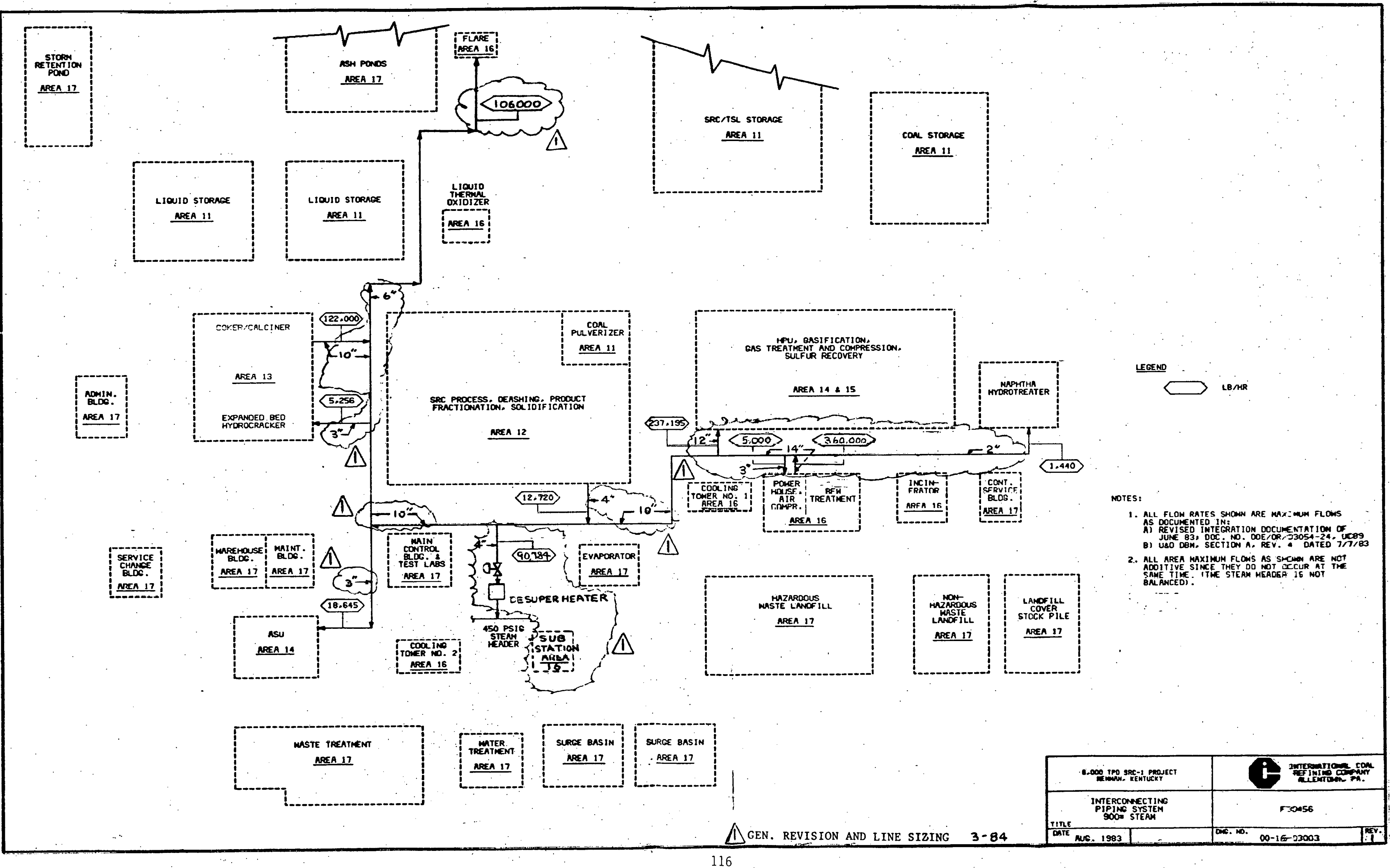




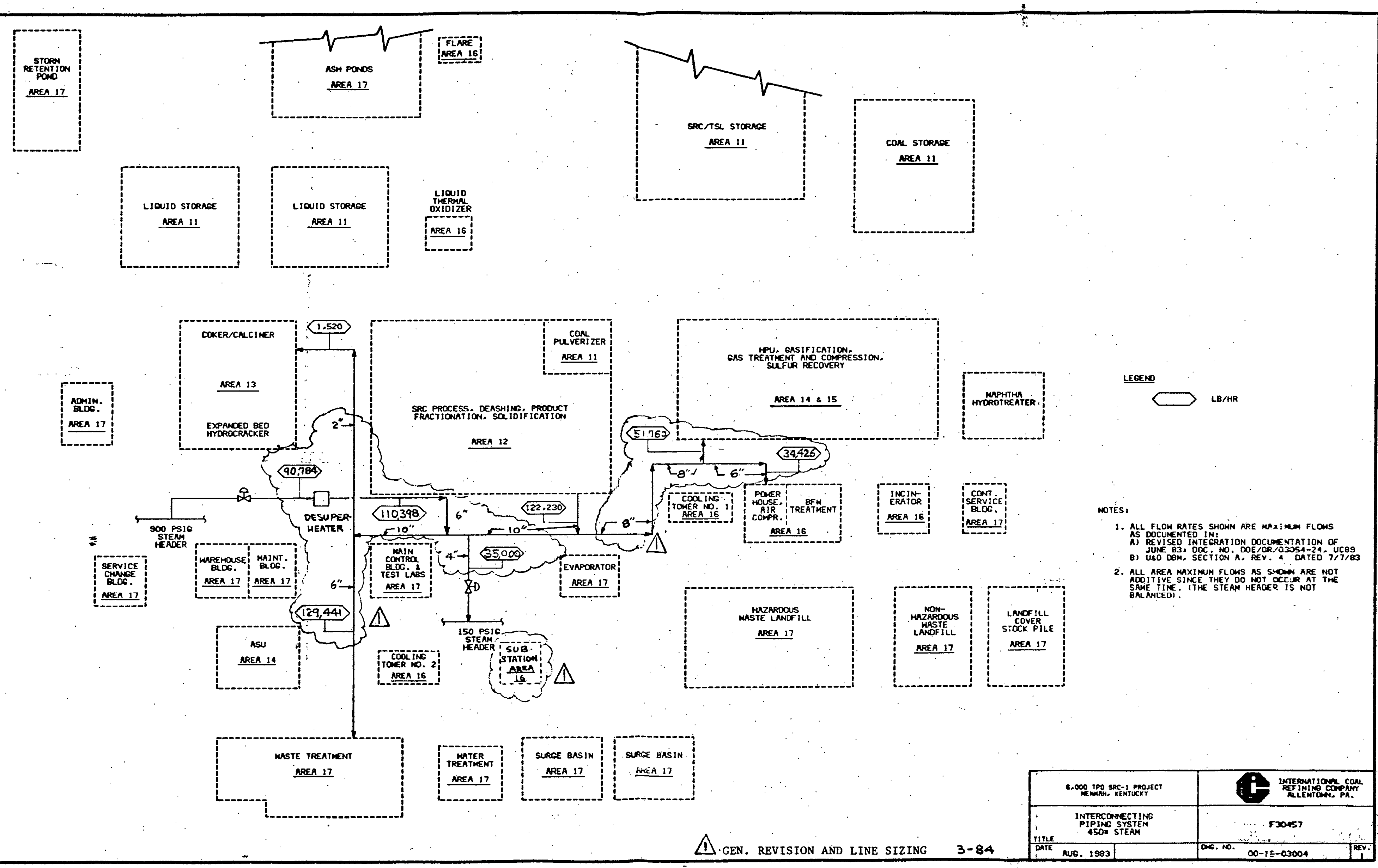




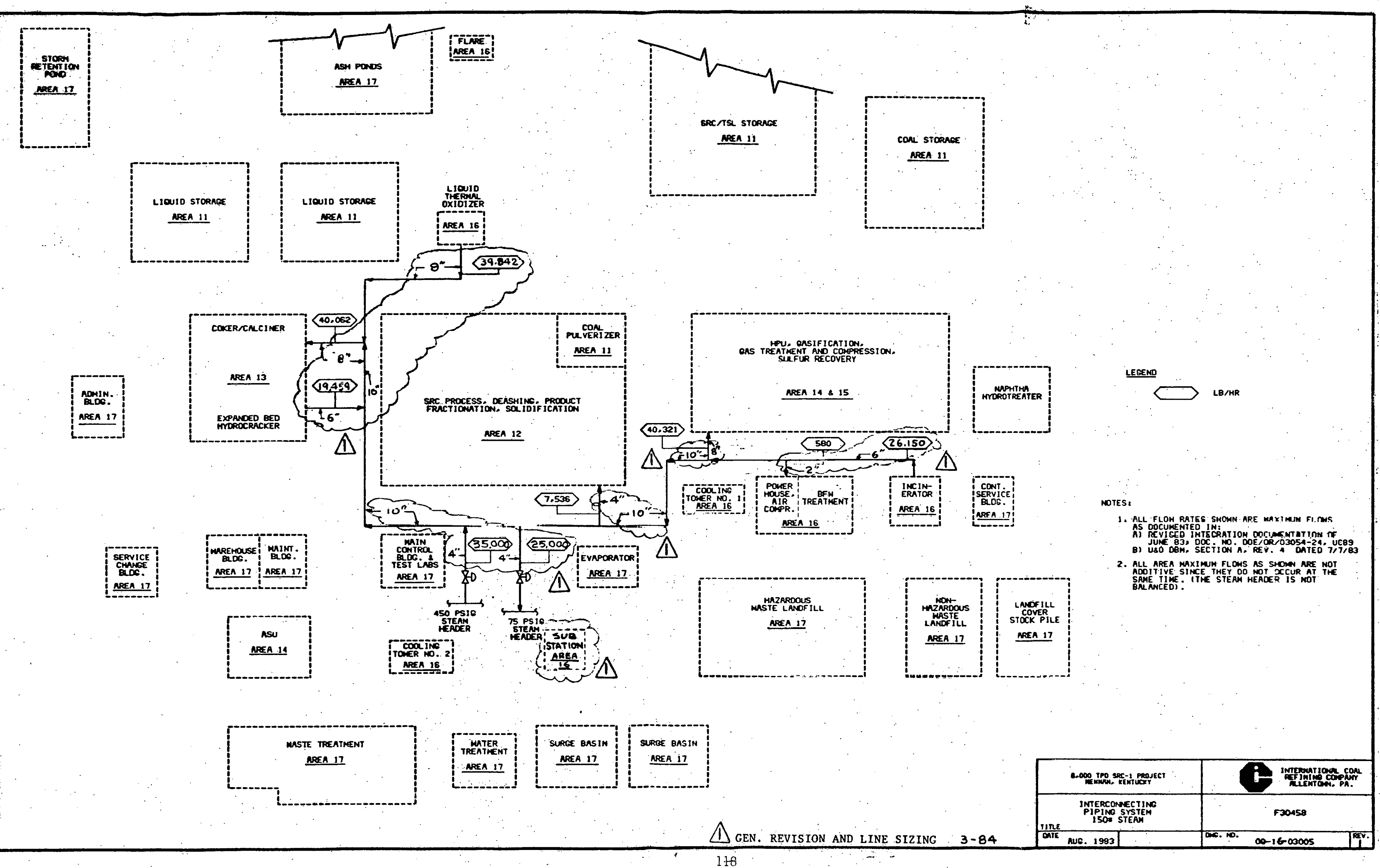




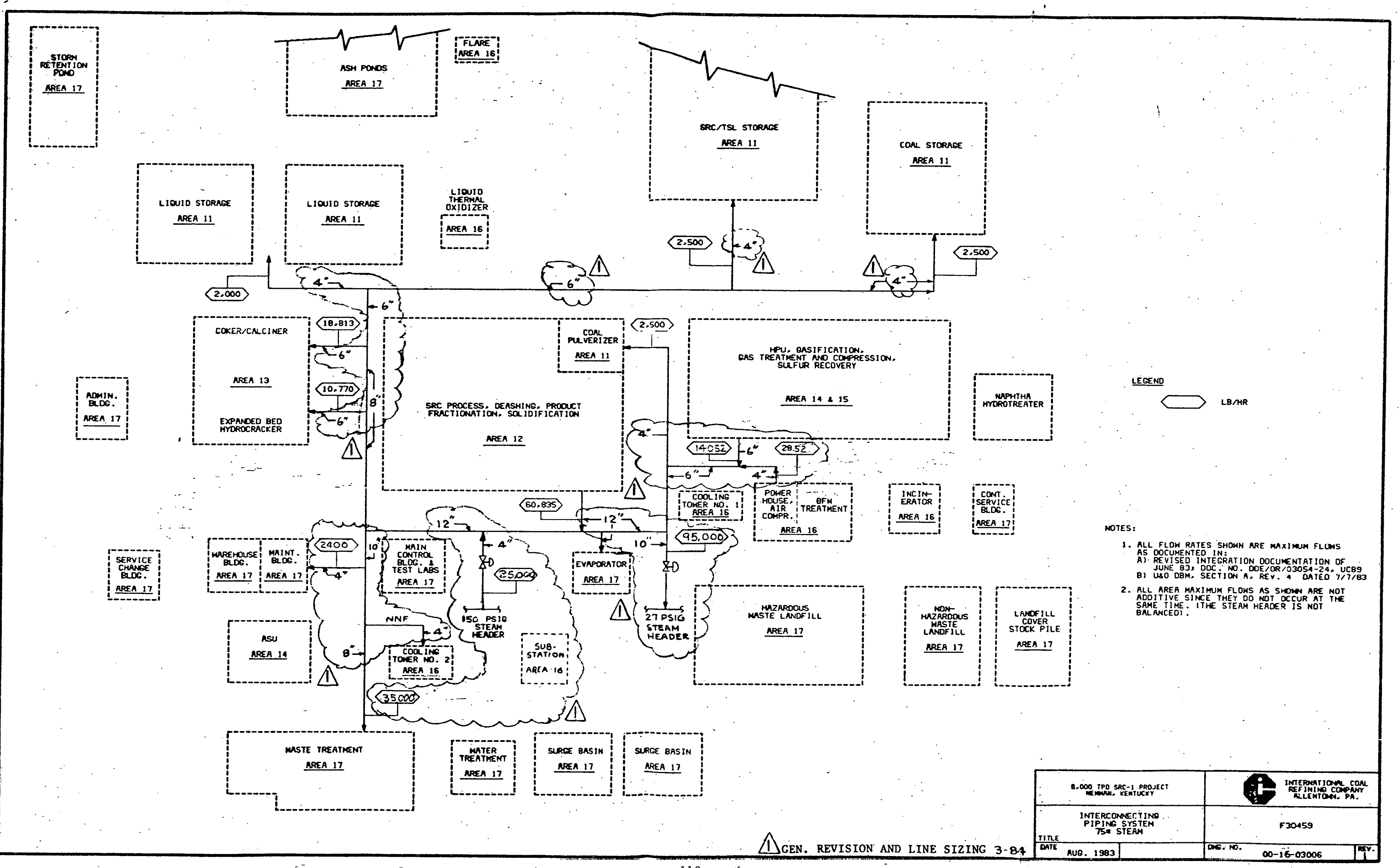




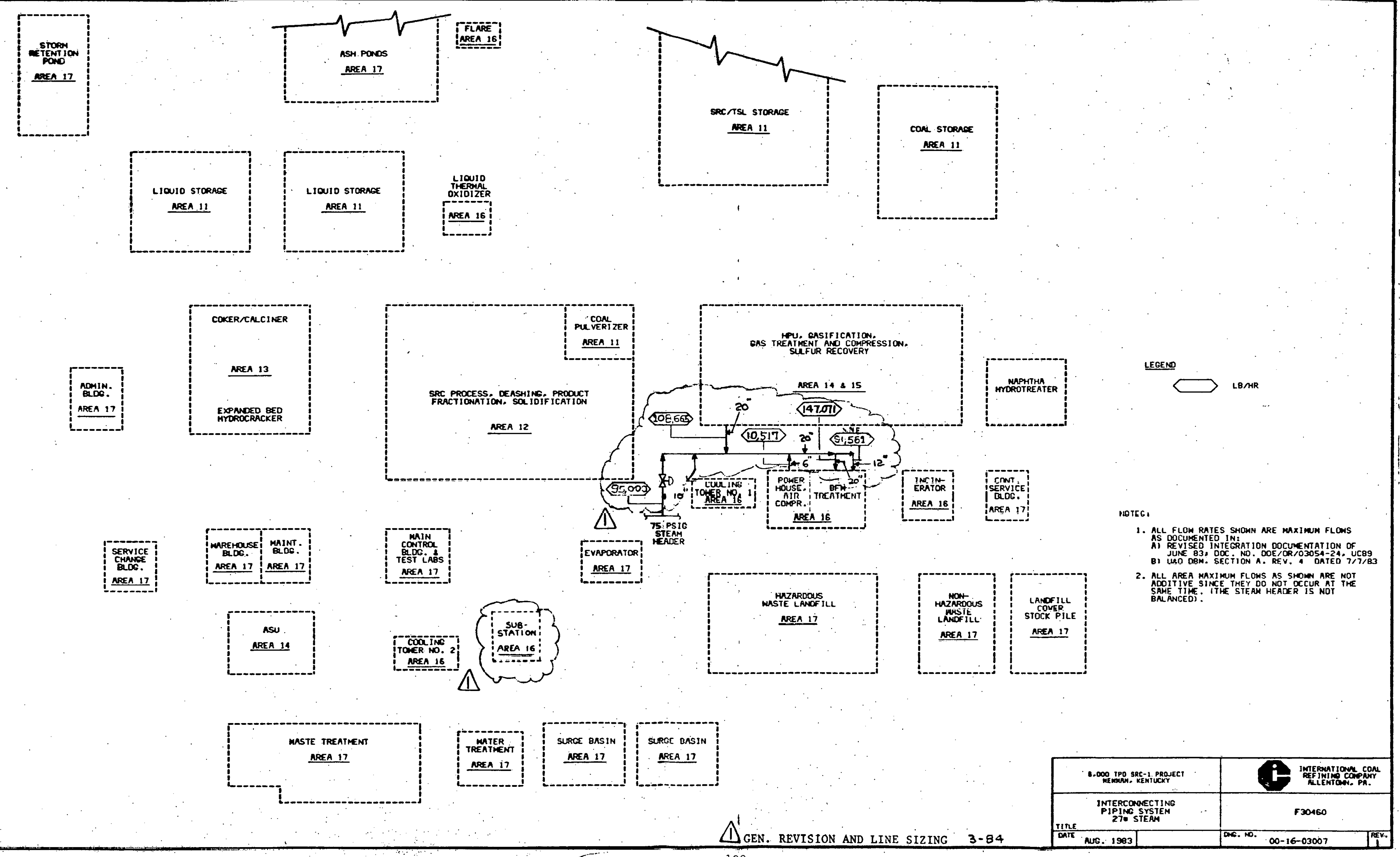




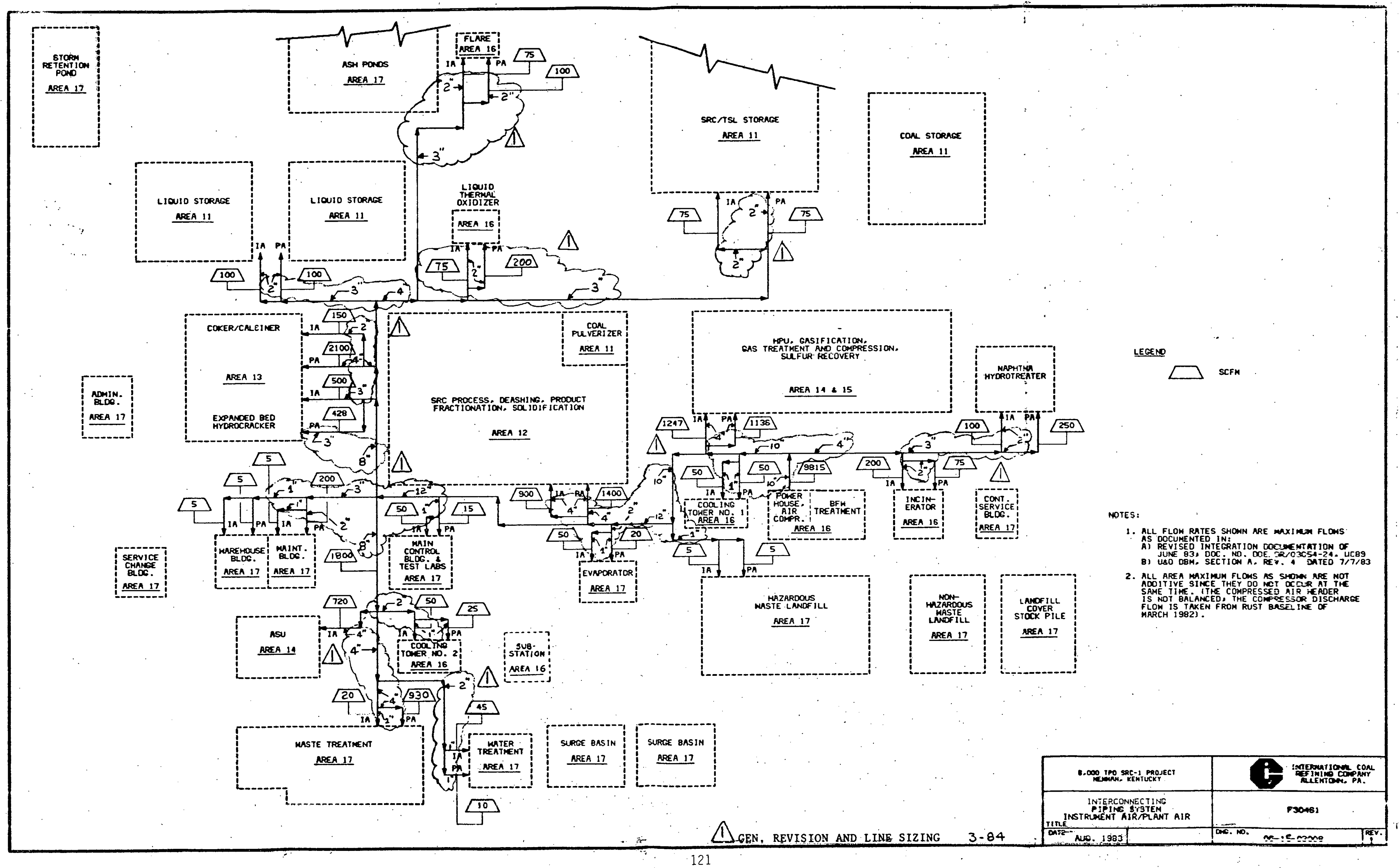




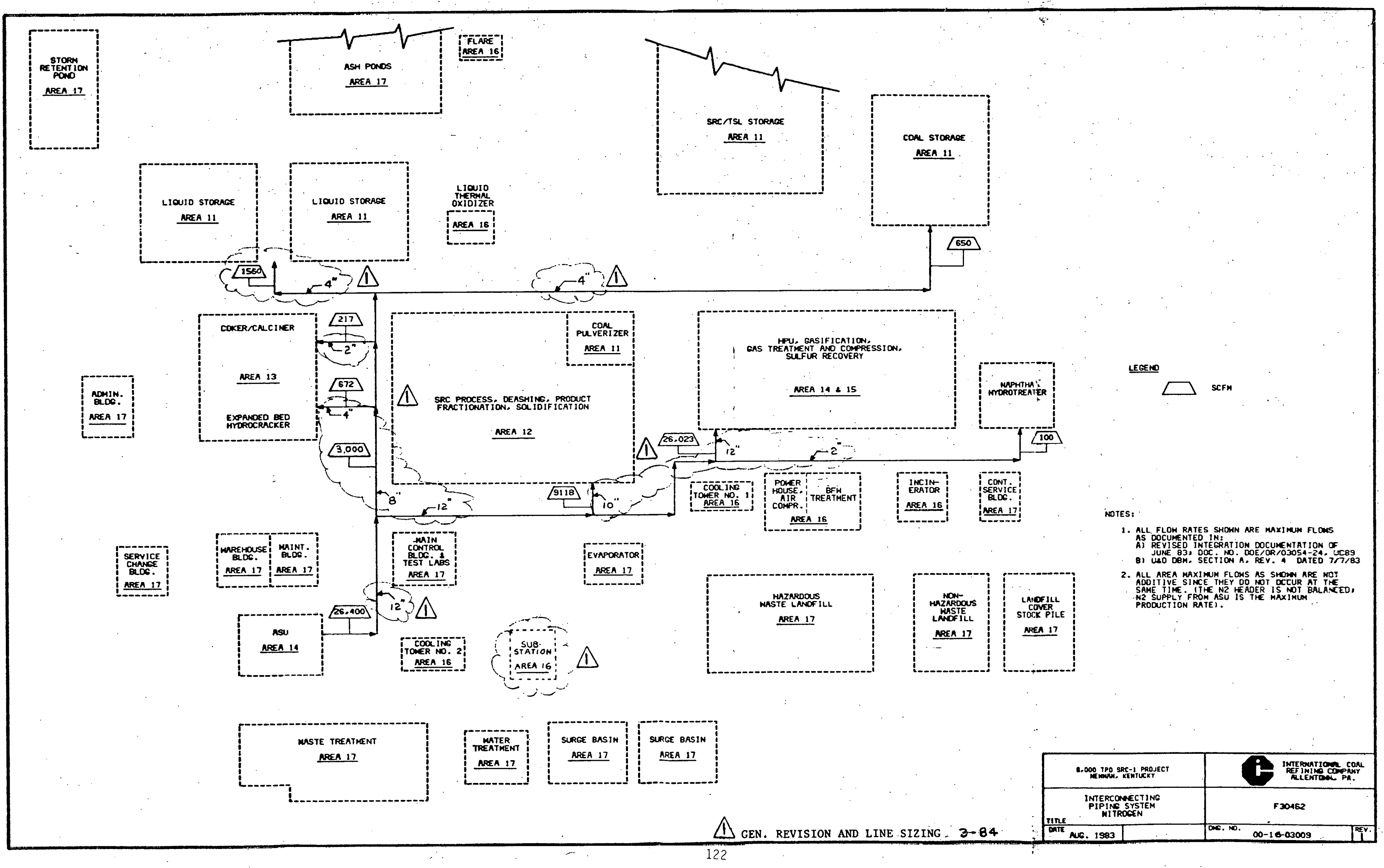




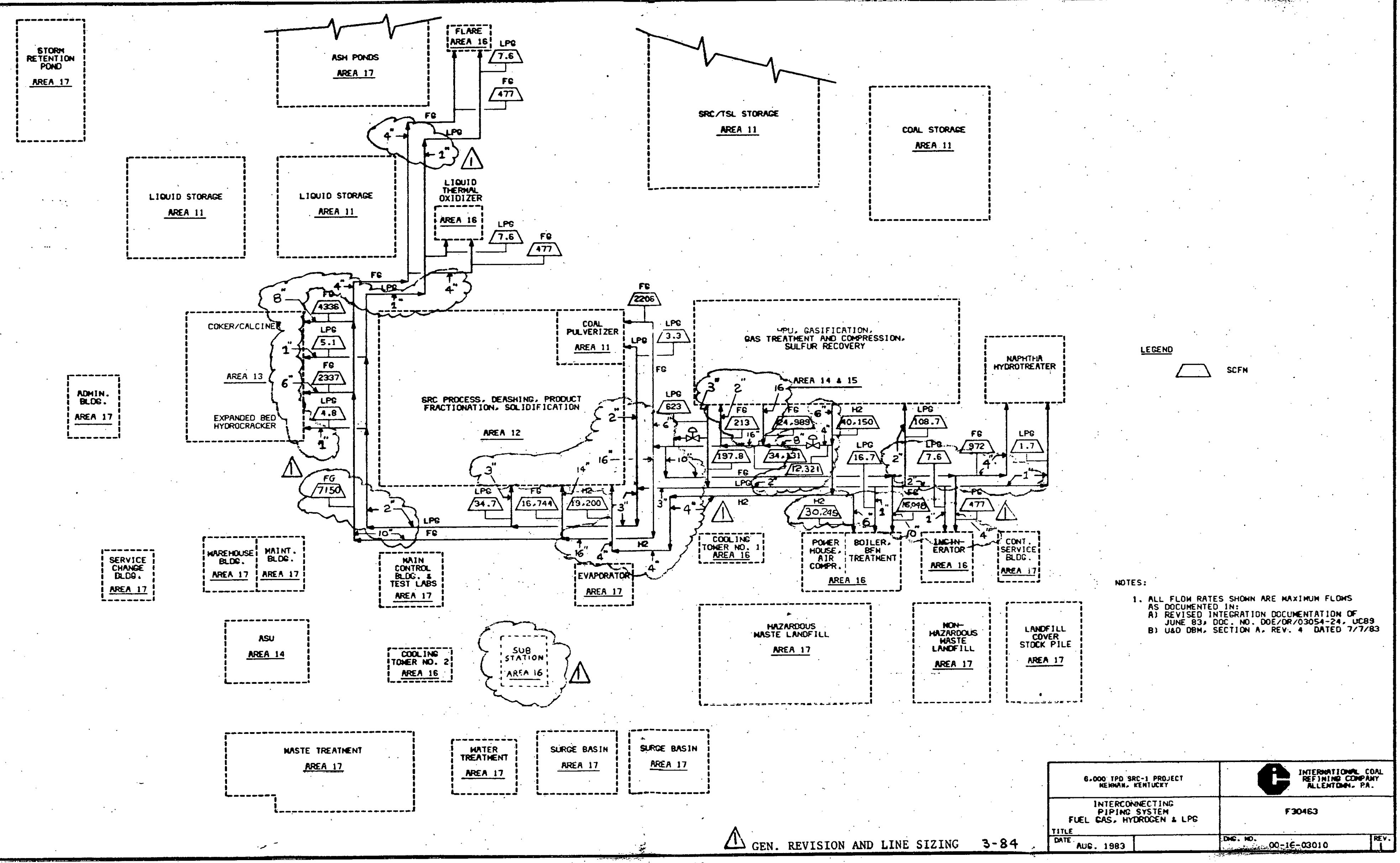




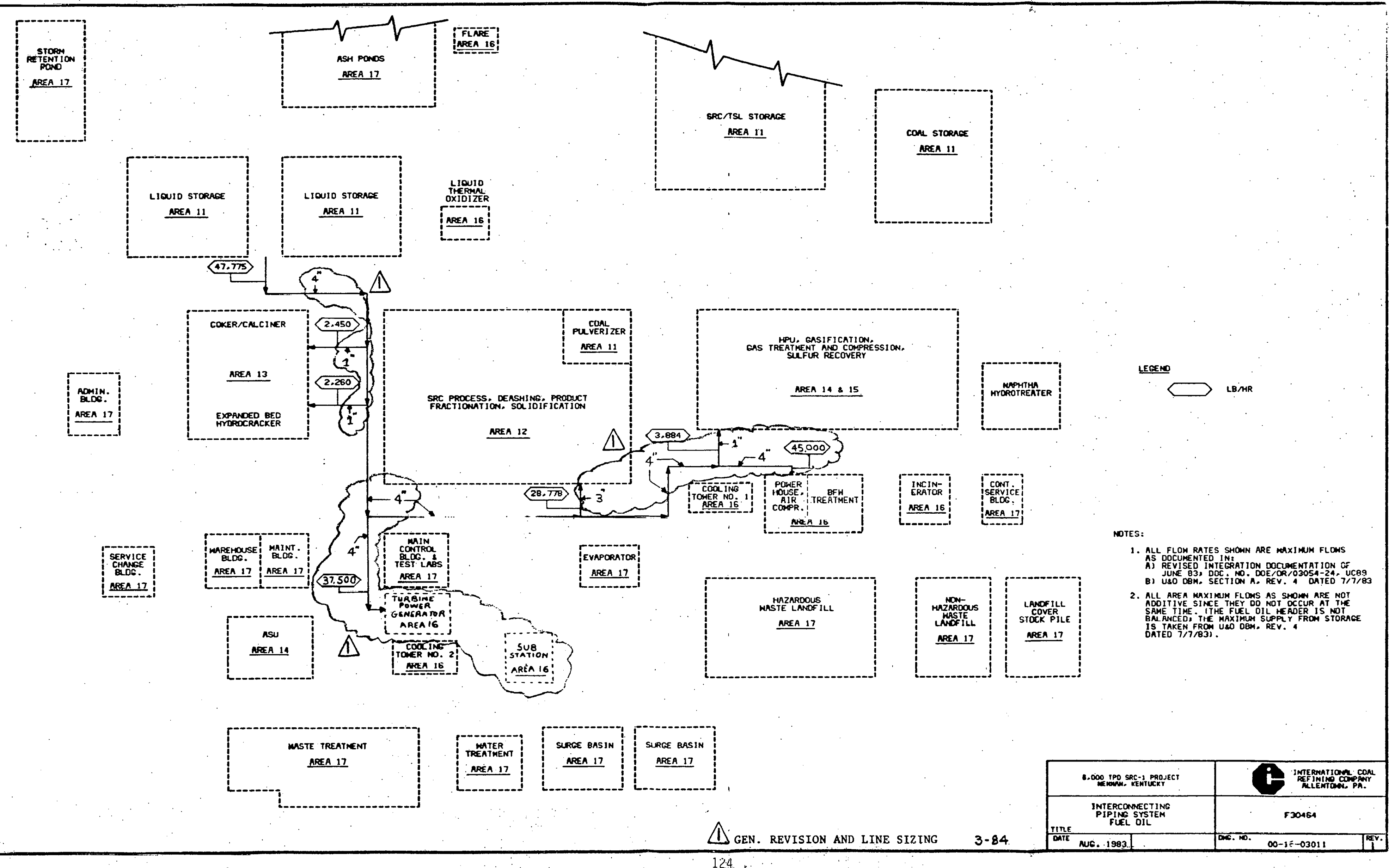




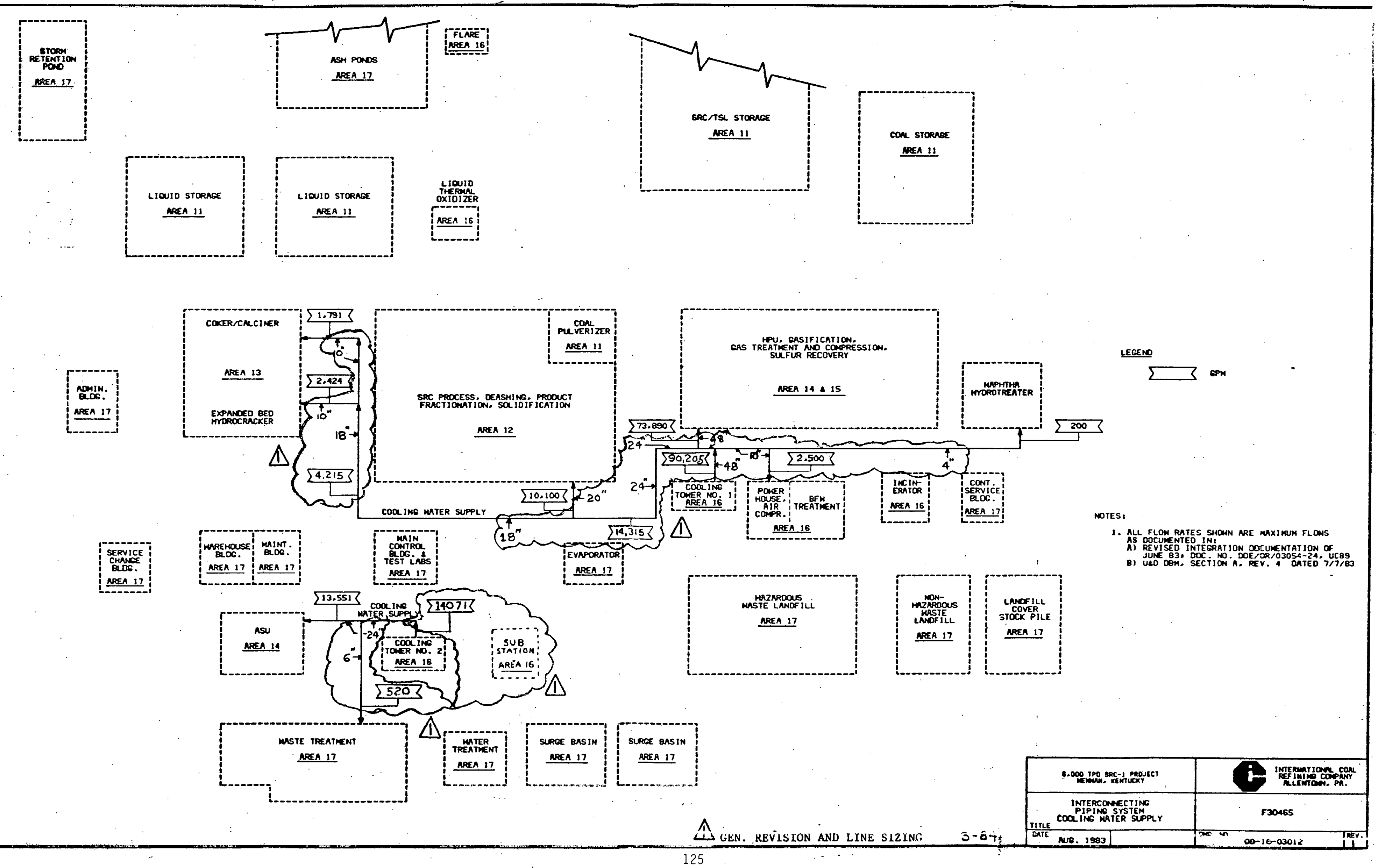




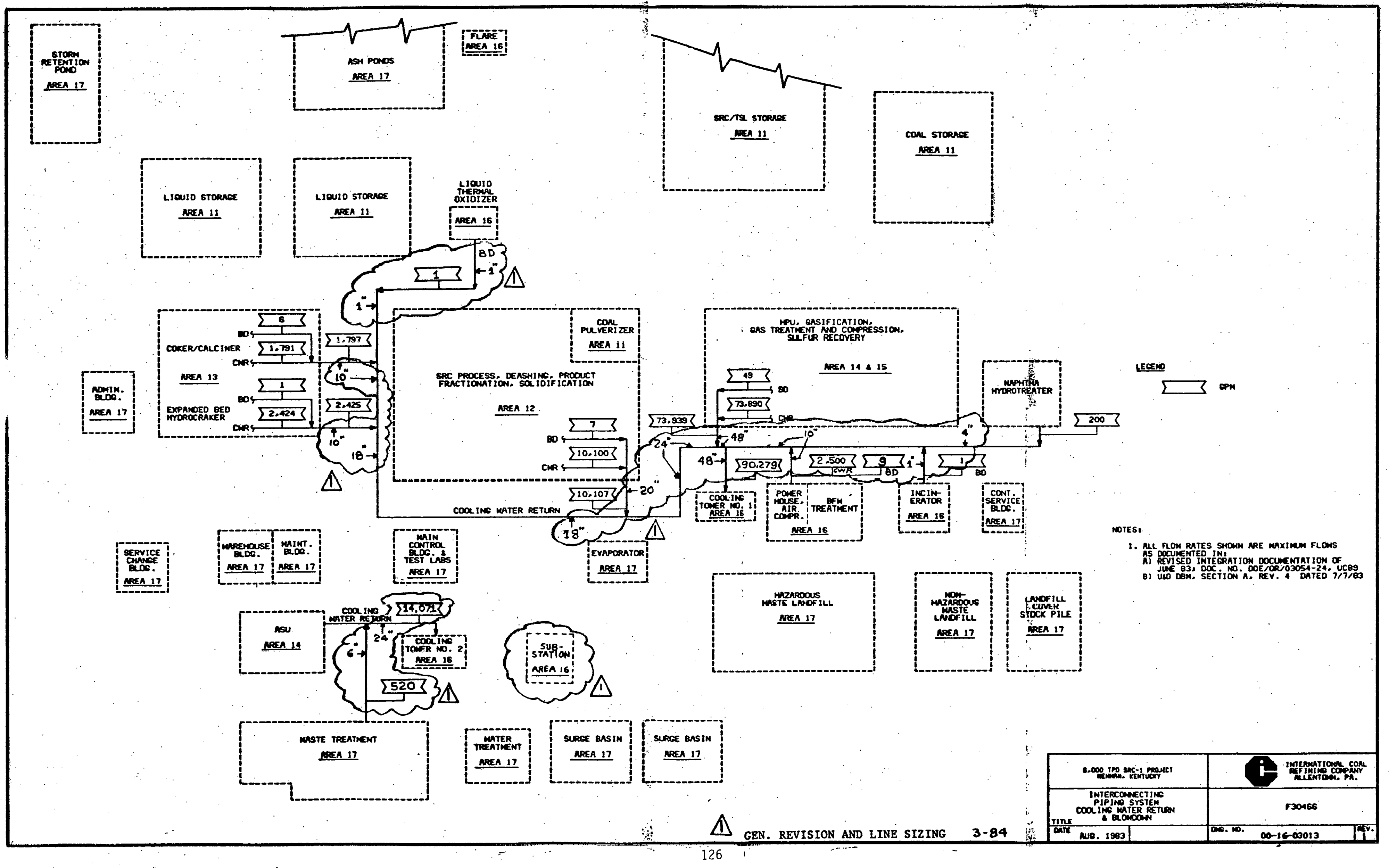




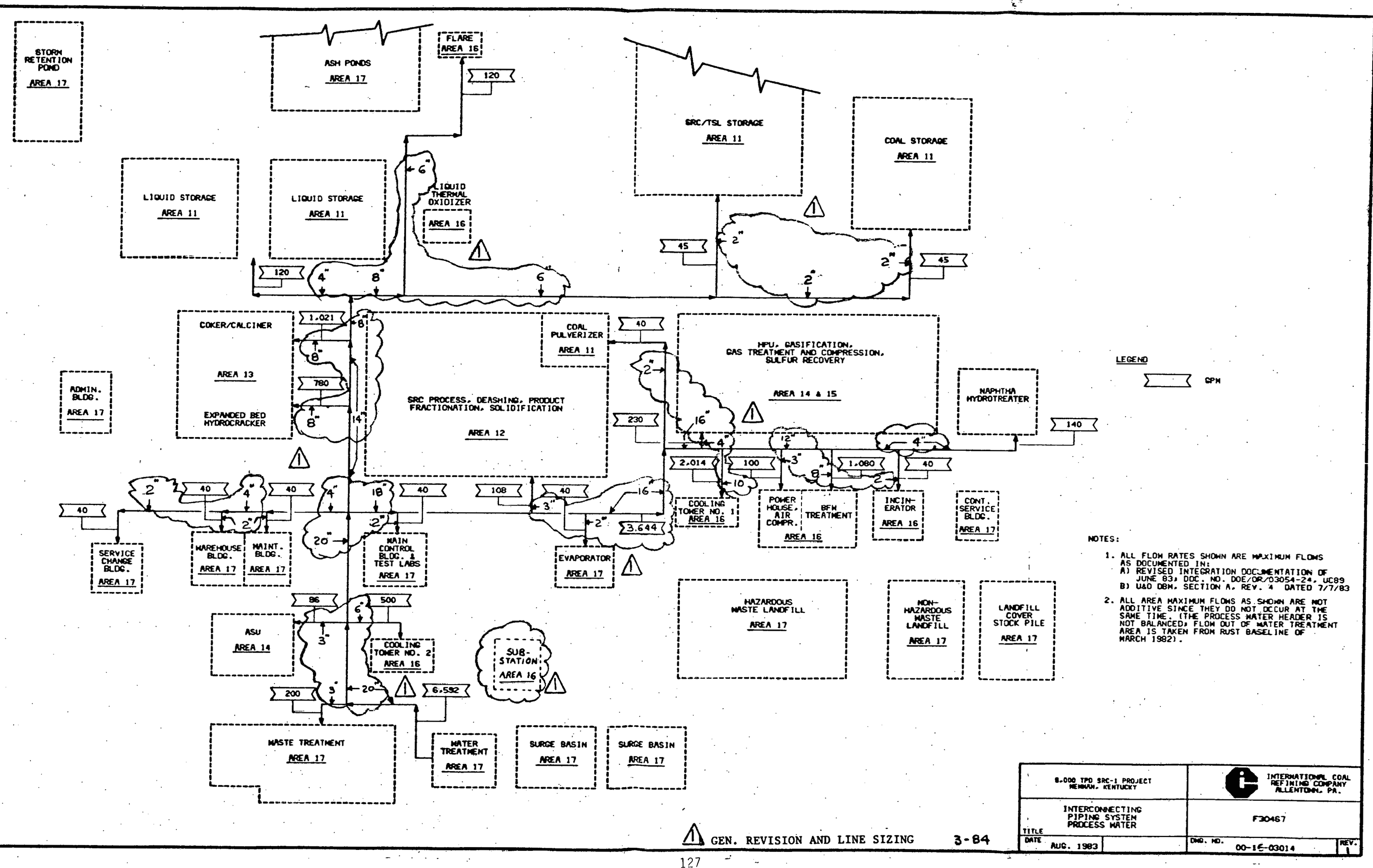




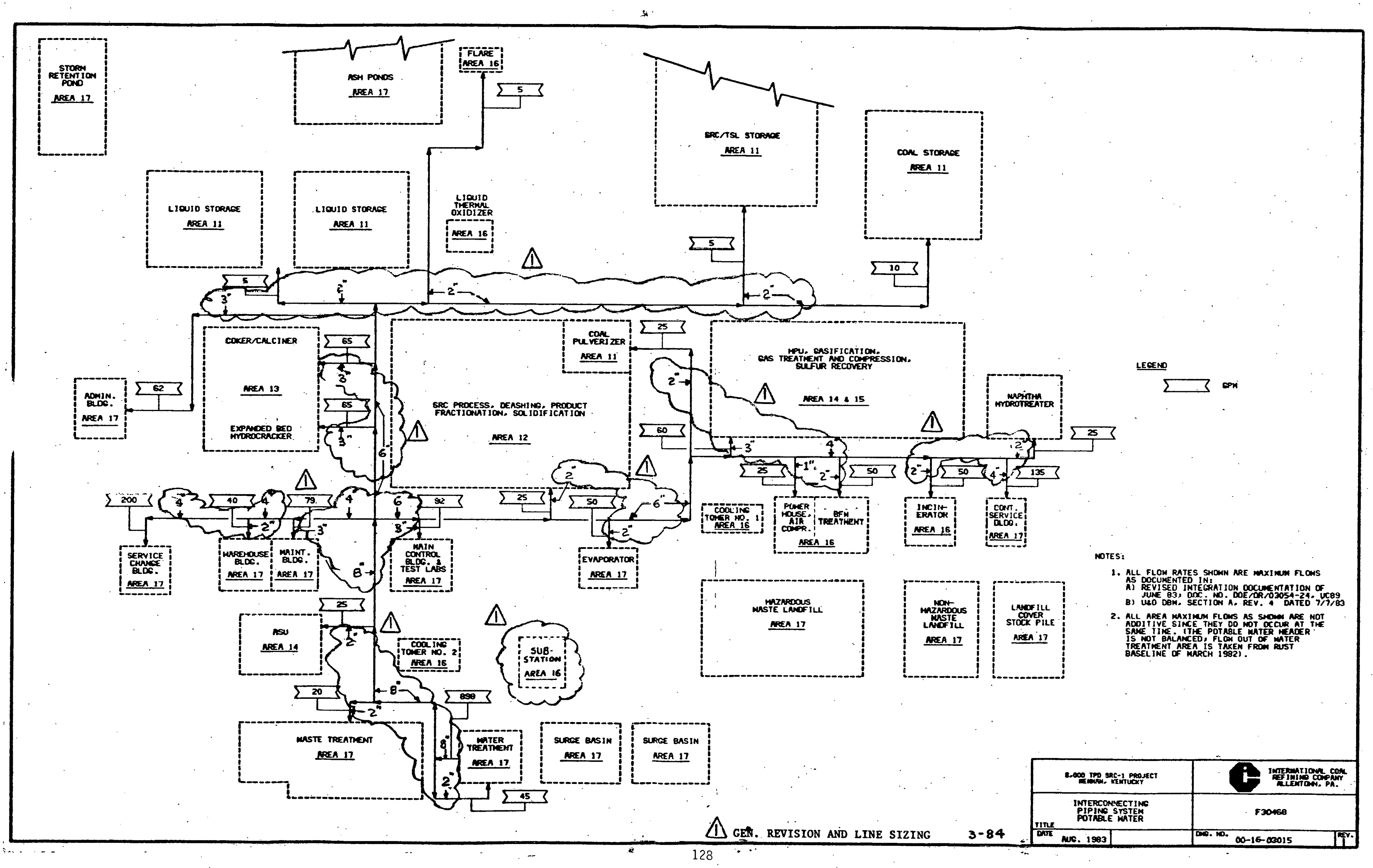




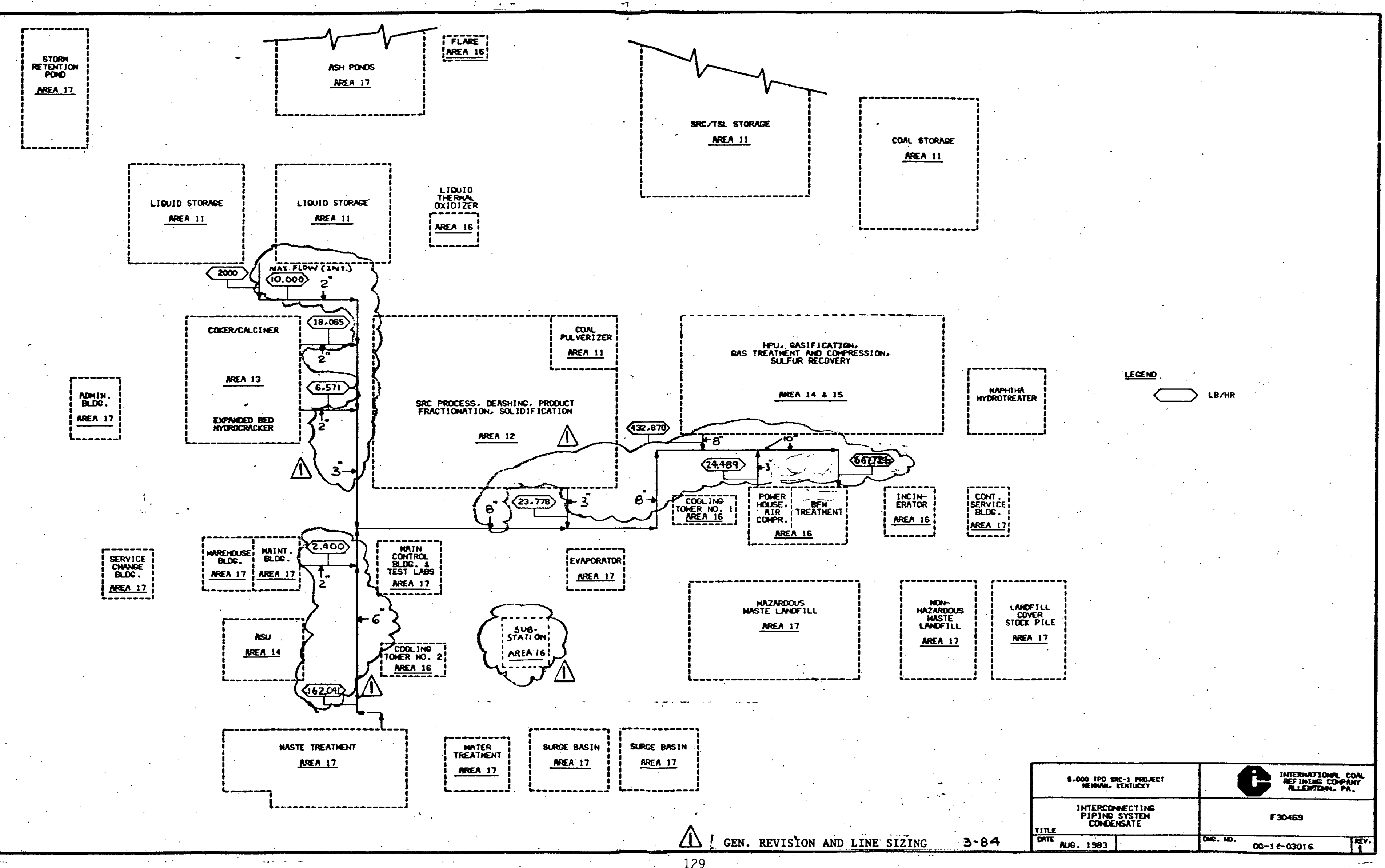


mUsT, DIALINOMAM, MLABAMA

tortha 215254

60 $\frac{1}{10 c}=-\frac{1}{15000}$ $x=7025$

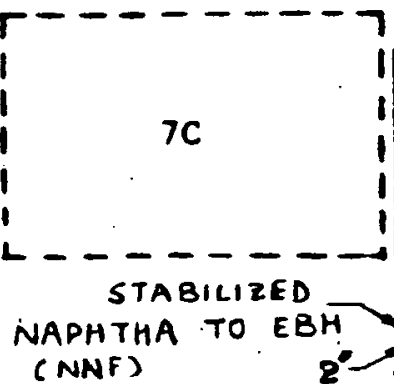

70 (NAF)
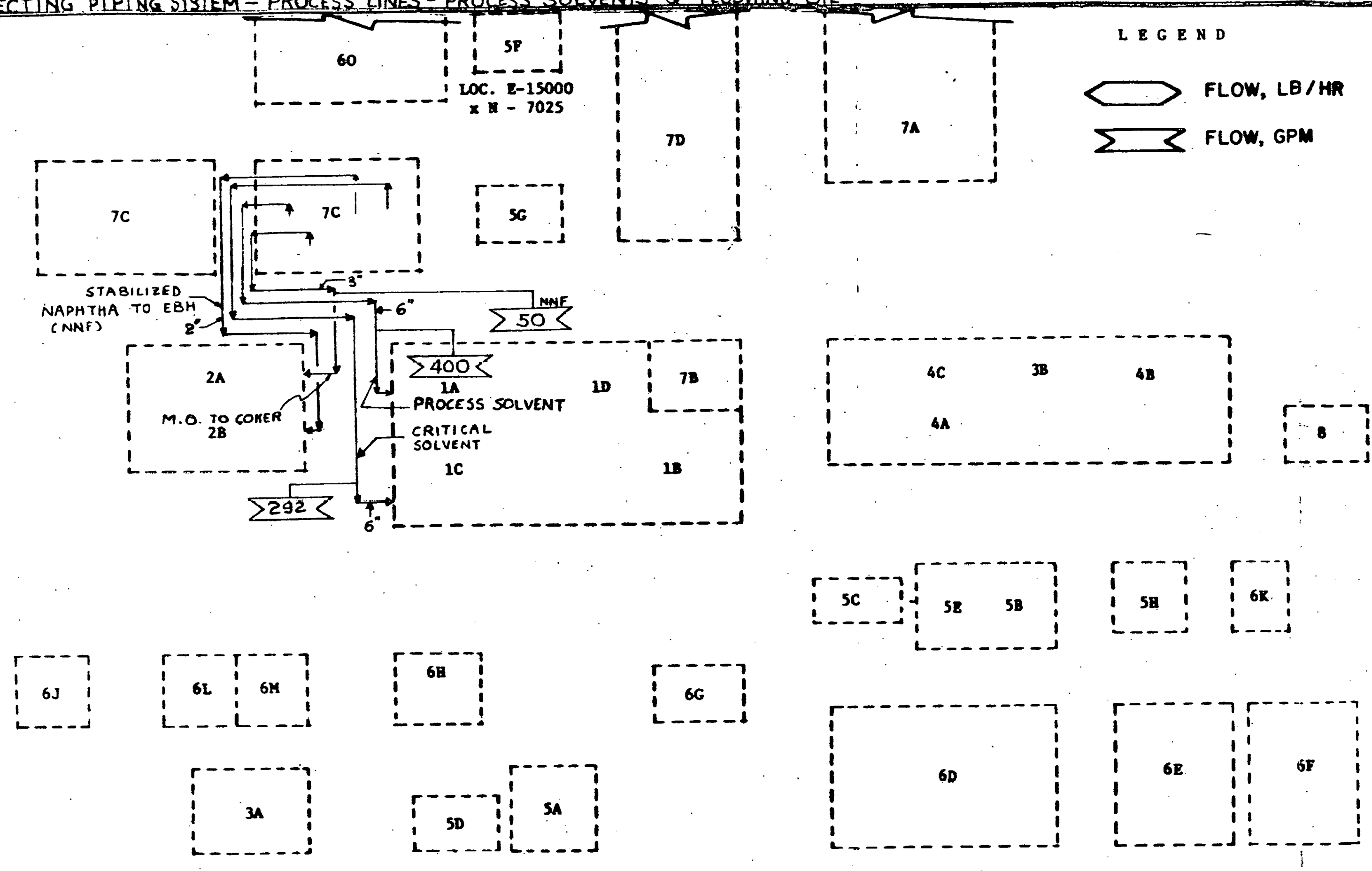

NOTES :
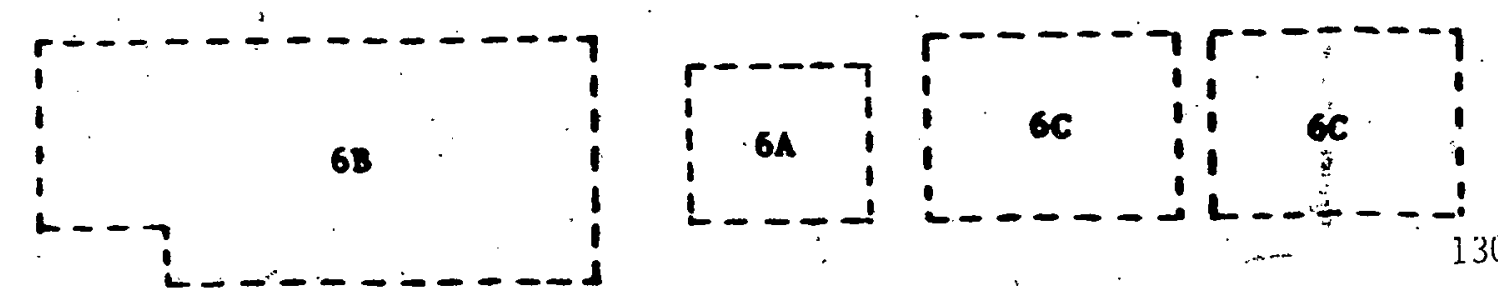

1. All flow rates shown are maximum flow rates.

2. Unless otherwise noted sll pipes are C.S.
1 AREA 12 SRC

In SRC Process

18 Deashing

IC Product Fractionation

1D Solidification

2 AREA 13 PRODUCT UPGRADING

2B Expanded-bed Hydroctacker

3 AREA 16 CRYOGENIC SEPARATION

nurification

4 AREA 15 GAS SYSTEMS

4A Gasification

4C Sulfur Recovery

5 AREA 16 UTILITIES

SA Main Substation

SB BFW Treatment

SC Cooling Tower No. 1
SD Cooling Tower No. 2

SE Power House and Air Compressor

56 Liquid Thermal Oxidizer

6 AREA 17 OFFSITES

6B Wasteuater Treacrone

6C Surge Basin

6D Hazardous Waste Landfil

6E Non-Hazardous Waste Landf111

F Landfill Cover Stock Pile

6G Evaporator

6H Central Control Bullding

61 Administration Building

6R Contract Maintenance Change BIds

Larehouse Bullding

6M Malncenance Butlding

ST Storention Pond

7 area 11 raw material \& prodict STORAGE

Coal Storage

B Coal Pulverize

7D SRC/TSL Storag

8 NAPHTHA HYDROTREATER 
must, BIAMINOHAM, ALABAMA
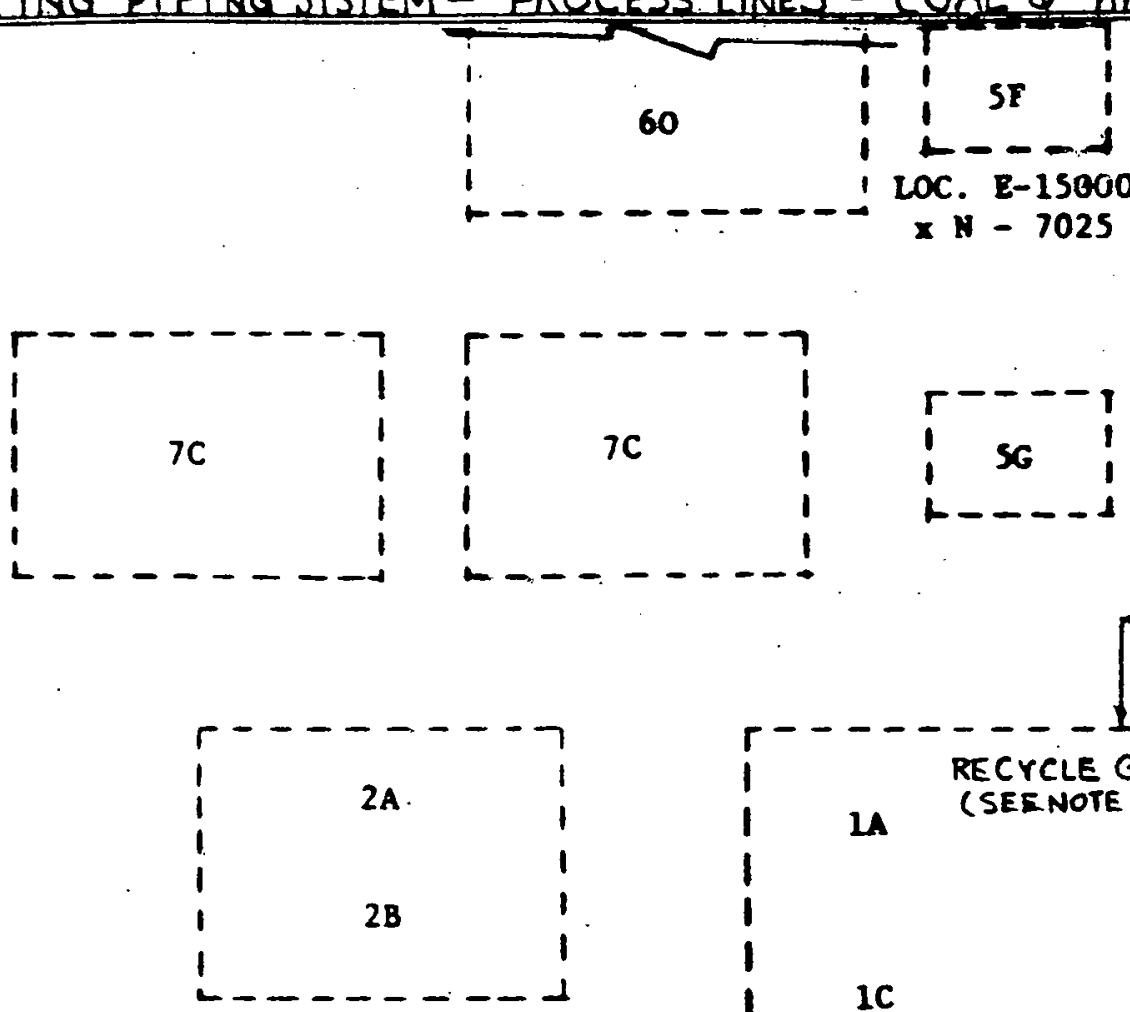

? 61
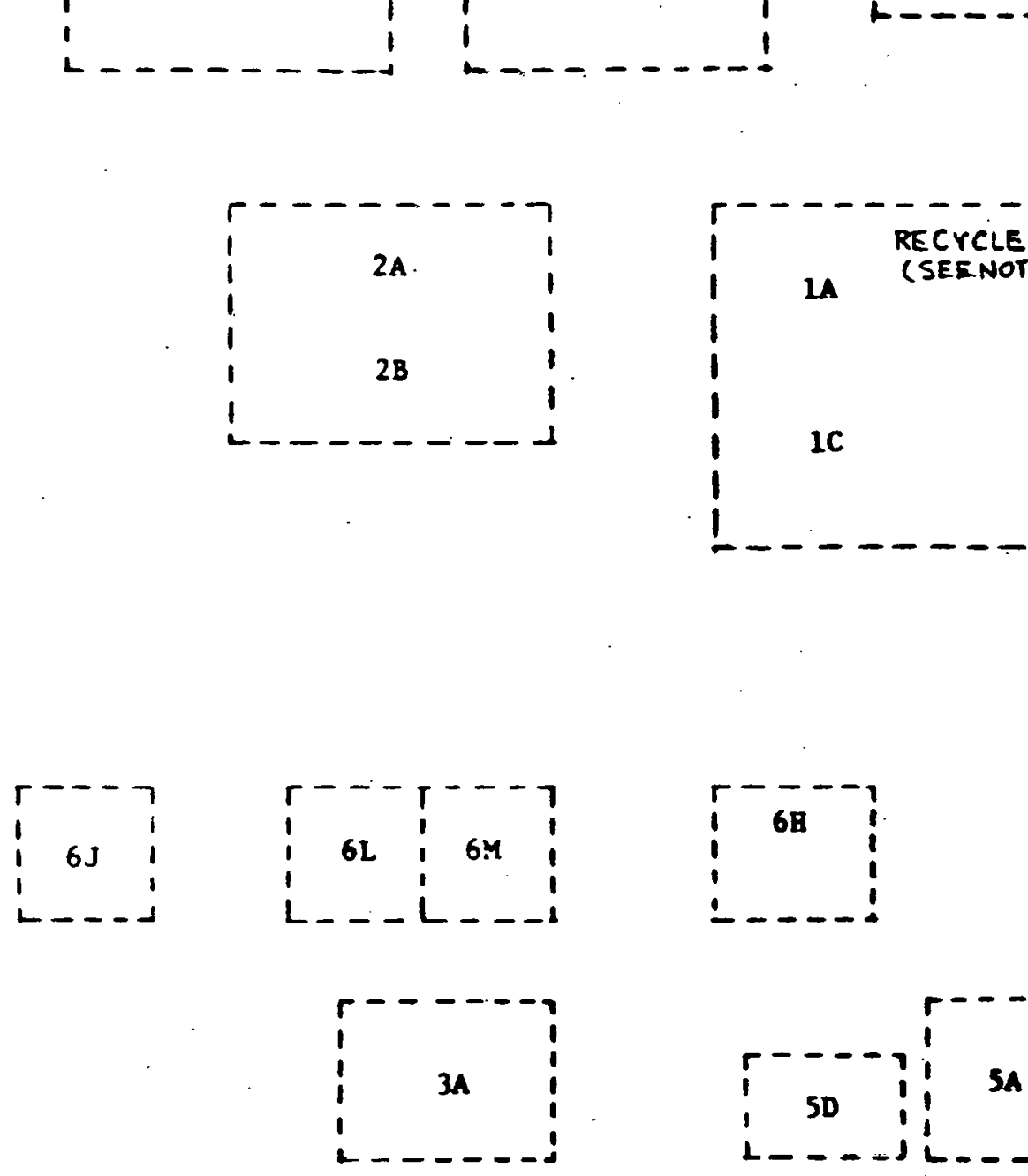
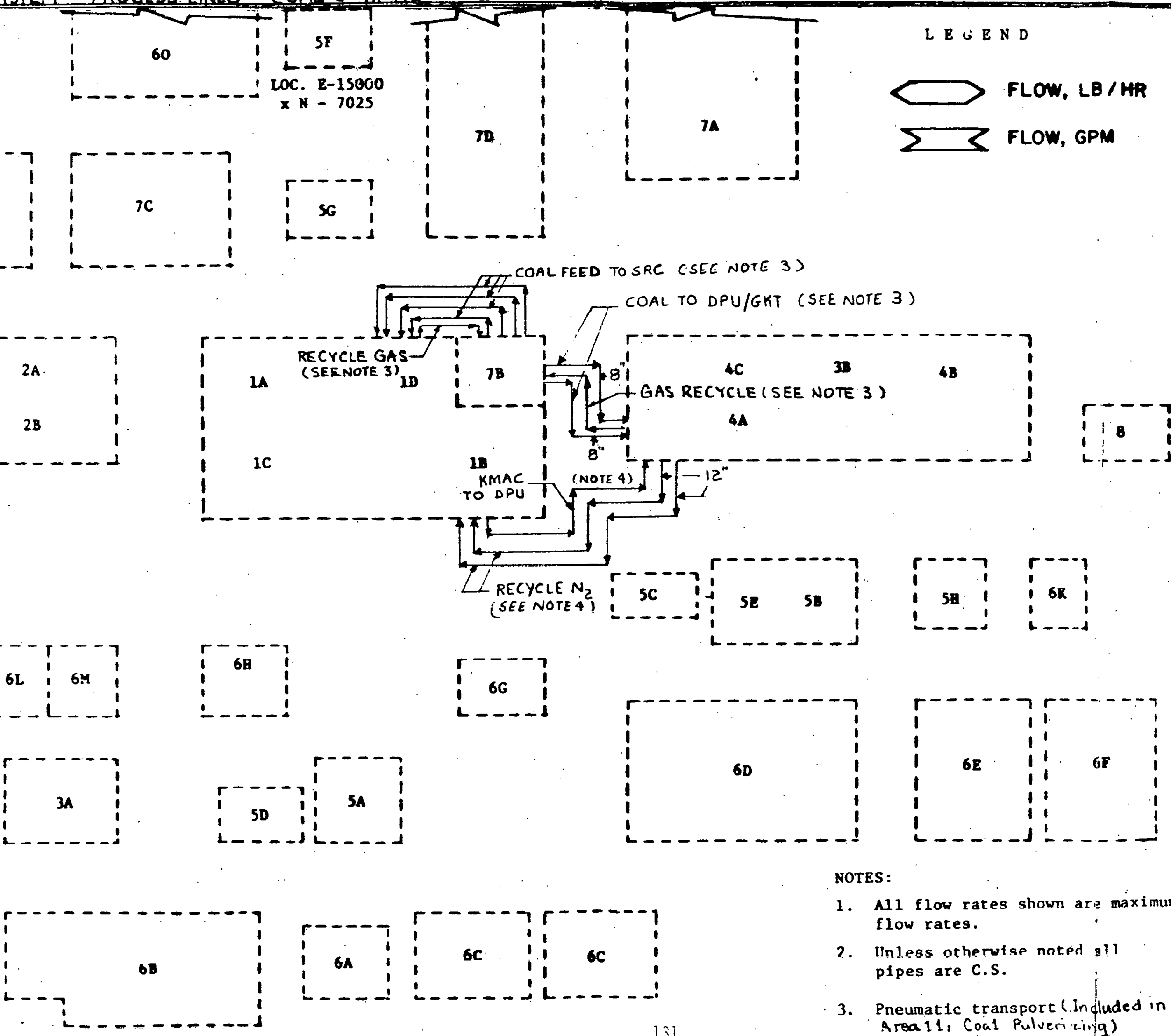

NOTES :

1. All flow rates show are maximum flow rates. pipes are C.S.

4. Prealli Coal Pulverizing
2. Inless otherwise noted all

3. Pneumatic transport (In qluded in
1 AREA 12 SRC

IA SRC Process

18 Deashing

IC Product Fractionation

ID Solidification

2 AREA 13 PRODUCT LPGRADING

2A Coker/Calciner

2B Expanded-bed Hydrocracke

3 AREA 14 CRYOGENIC SEPARATIUN Air Separation

B Aydrogen Purlfication

4 AREA 15 GAS SYSTEYS

AA Gasification

4C Sulfur

5 AREA 16 UTILITIES

SA Maín Substation

5B BFW Treatment

SC Coollng Tower No. 1

5D Cooling Tower No. 2

SE Power House and Air Compressor

SF Flare

SG Liquid Thermal Oxidizer

SH Gas Incinerator

6 AREA 17 OFFSITES

6B Wastewater Treactient

6C Surge Basin

6D Hazardous Waste Land 111

$6 E$ Non-Hazardous Waste Landf 111

6F Landfill Cover Stock Pile

6G Evaporator

6H Central Control Burlding

6I Adminlstration Bullding

6K Contract Maintenance Change Bidg.

6L Warehouse Bullding

6M Maintenance Building

6N Storm Retention Pond

60 Ash Ponds

area 11 raw material o PROE:C: STORAGE

7 A Coal Storage

$7 \mathrm{~B}$ Coal Pulverizer

7D SRC/TSL Storage

NAPHTHA HYDROTREATER 
nusT, DAAMINOMAM, ALABAMA

T insotio $z_{1}-2548$

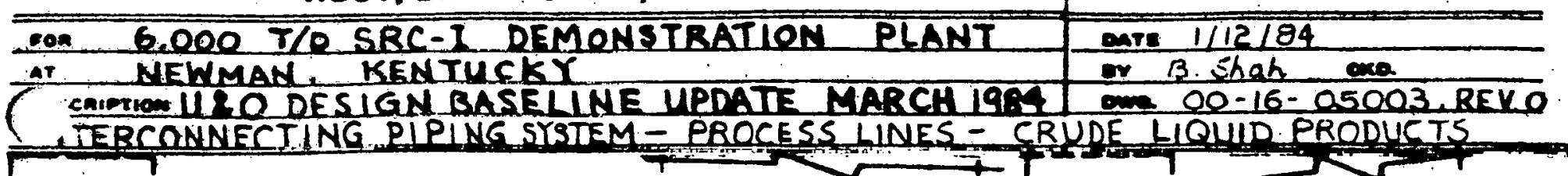

6N

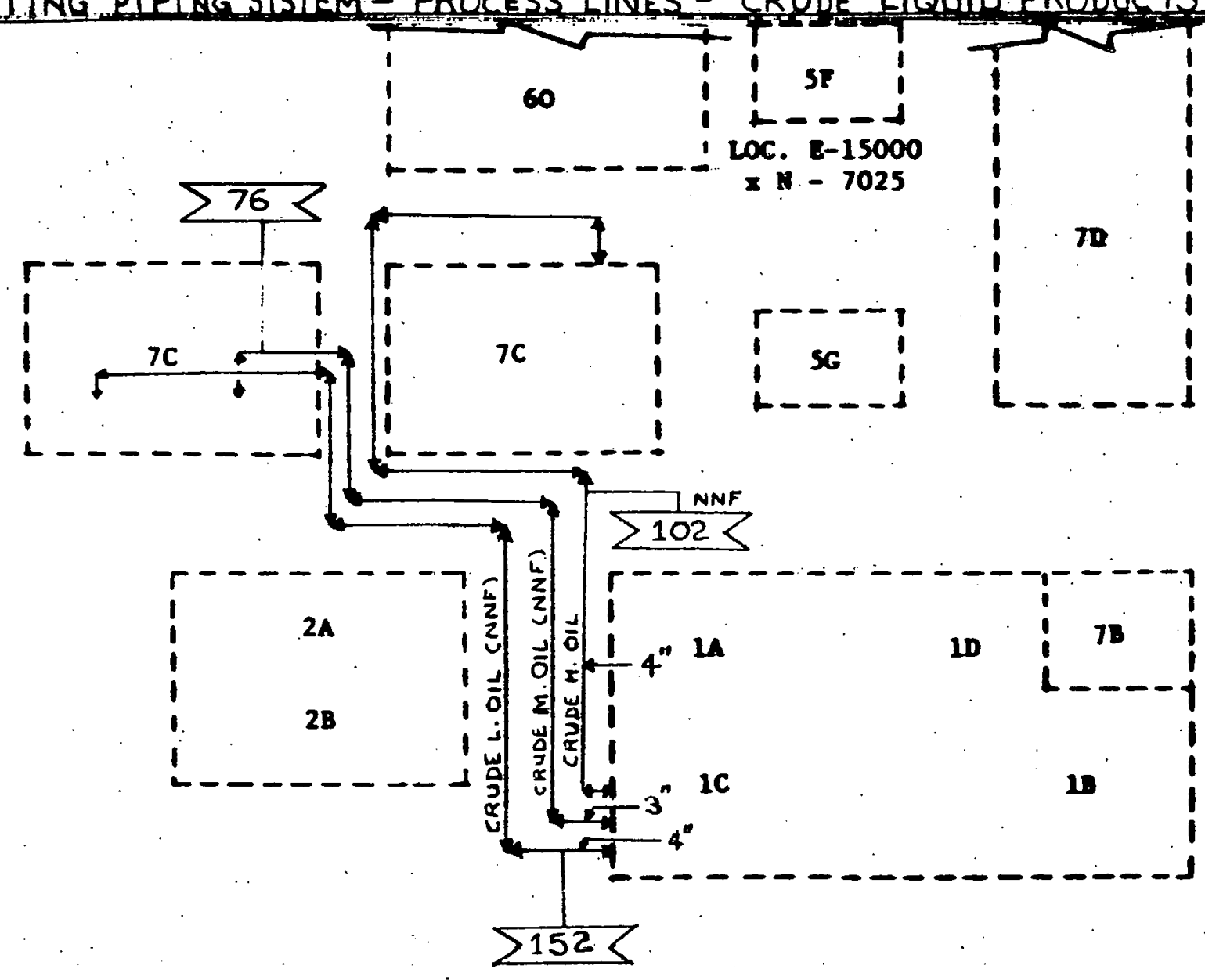

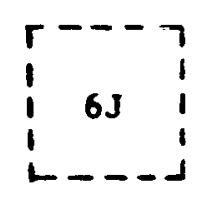
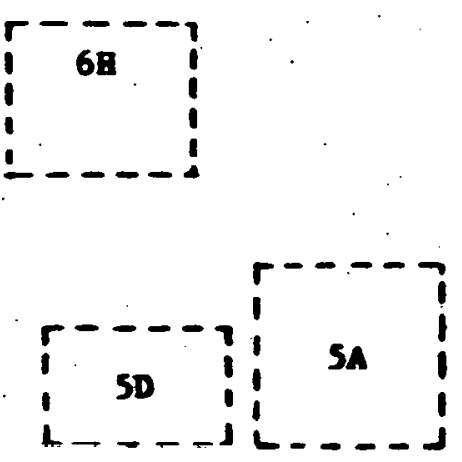

i. so
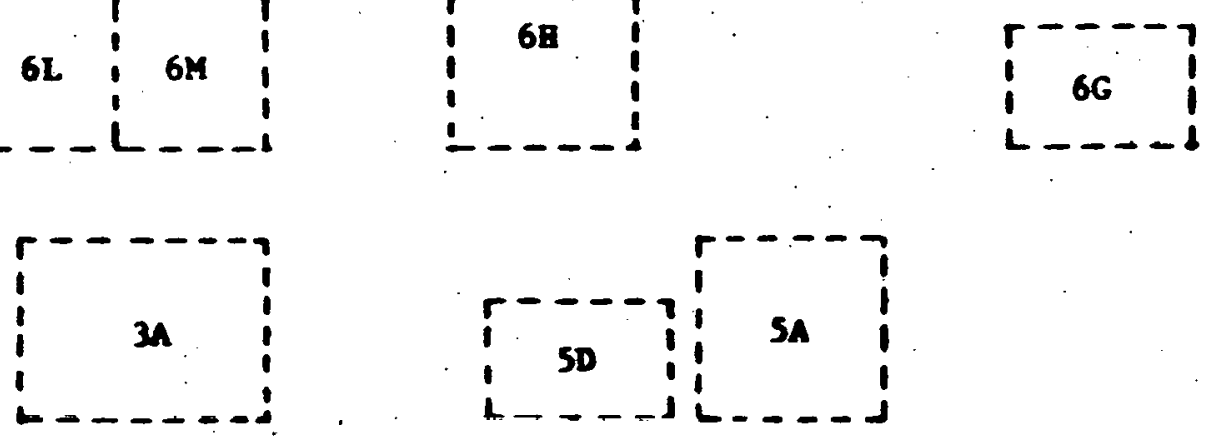
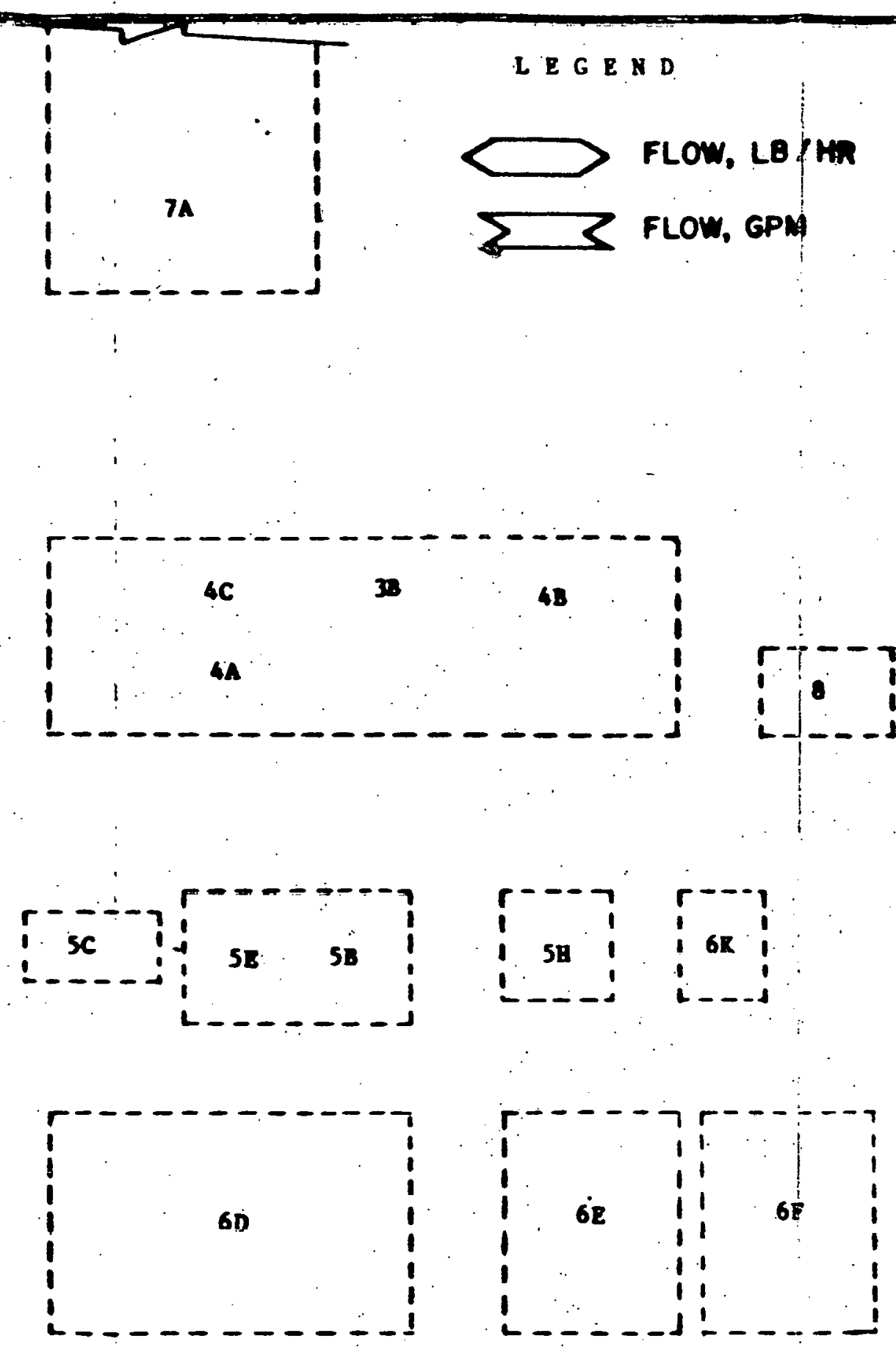

NoTES

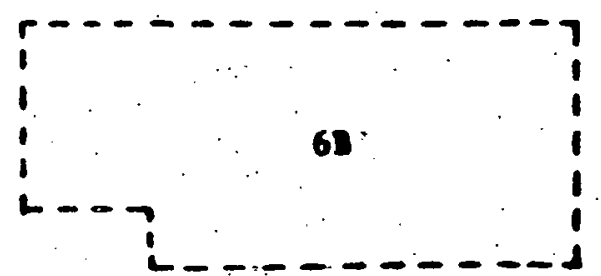

All flow rates shown are maximum flow rates.

2. Unless otherwise noted all pipes are C.S.
1 AREA 12 SRC

UA SRC Proceso

Ceashing

antion

ID Solidification

2 AREA 13 PEODUCT UPGRADTEC

2B Expanded-bed Eydrocracker

3 AREA 14 CRYOGEIIC SEPARATION MA Arr Separation

38 Aydrogen Purificat 1o

AREA 15 GAS SYSTEMS

An Gabiflcation

Gas Trea

C Sulfur Recover

5 AREA 16 UTILITIES

SA Substation

SA Treatmen

SD Coollag Taver to.

SE Power House and A1r Compressor

SF Flare

SC Liquid Thermal Oxidizer

58 Gas Incinerator

6 AREA 17 OFFSITES

$6 A$ Water Treatnent

6B Wastewater Treatmen

6C Surge Basin

6D Hazardous Haste Landfill

6E Non-Hazardous Waste Landfil

6F Landfill Cover Stock Pile

Ge Evaporator

6I Central Control Bullding

iJ Mitulation bullding

6r Contract Masatenance Chan

hange B1dg.

Warehouse Bulldiag

6N Stor Retention Pond

60 Ash Ponds

AREA 11 RAH MATERIAL 5 PRODCICT STORAGE

$7 A$ Coal Storage

78 Coal Pulverizer

7C Liquid Storage
7D SRC/TSL Storage

8 NAPHTRA HYDRETREATE 
FUST, BIRMINOMAM, ALABAMA

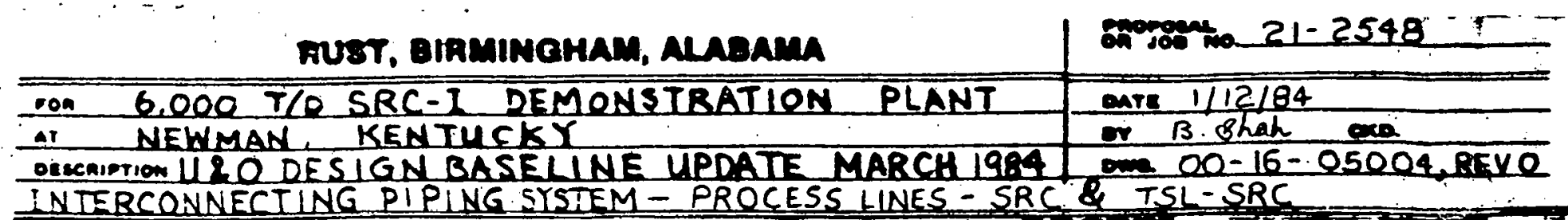

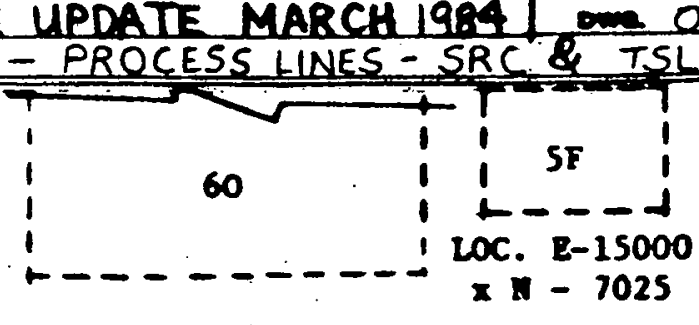

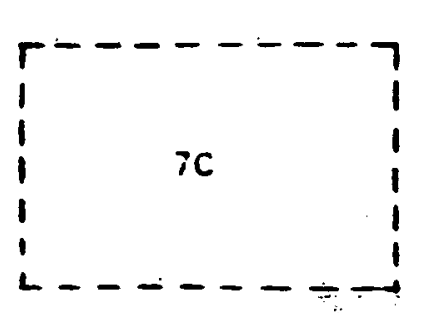

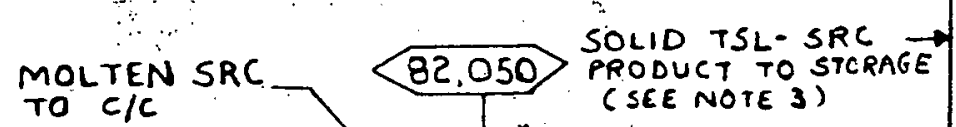

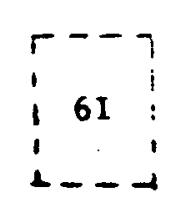

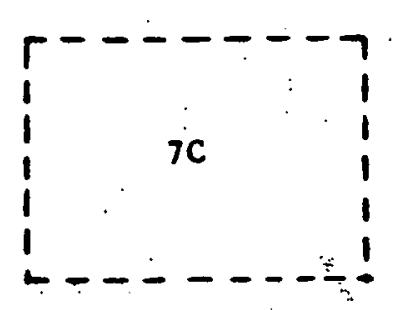

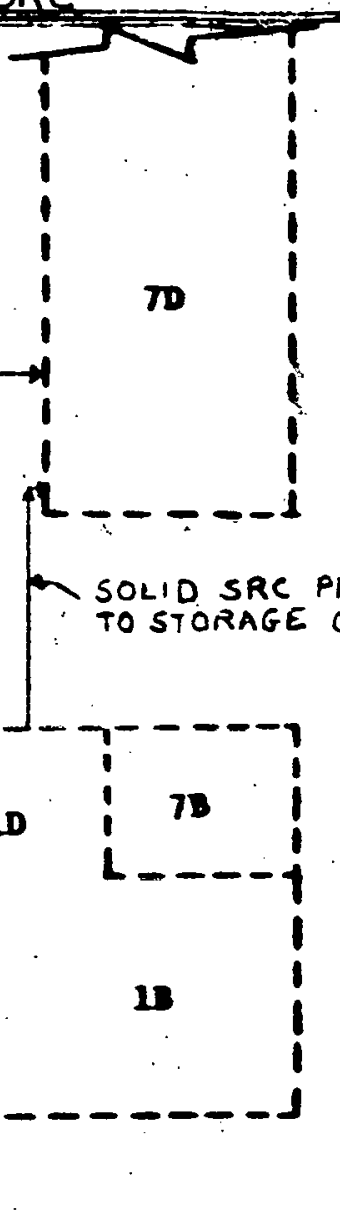

169.558

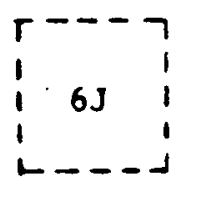

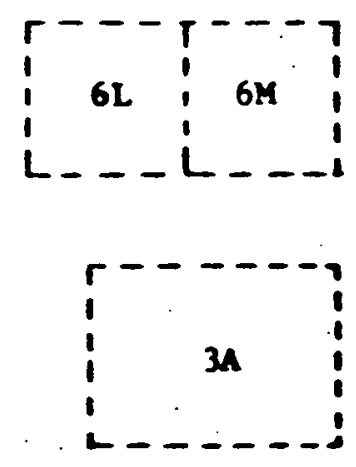
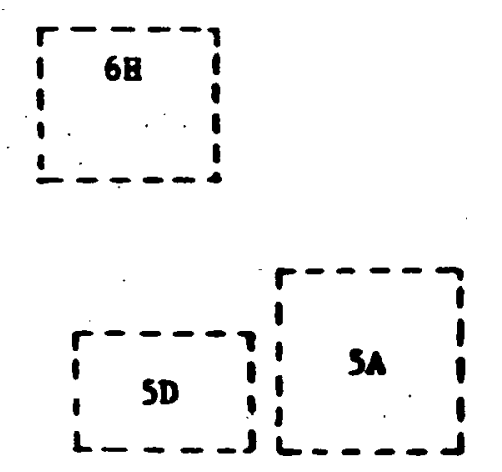

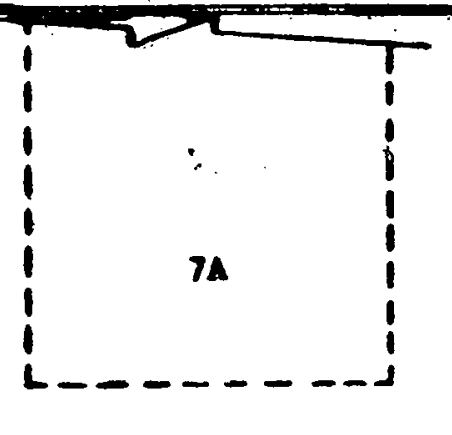

$$
\text { UCT }
$$

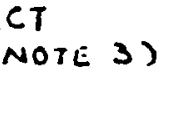

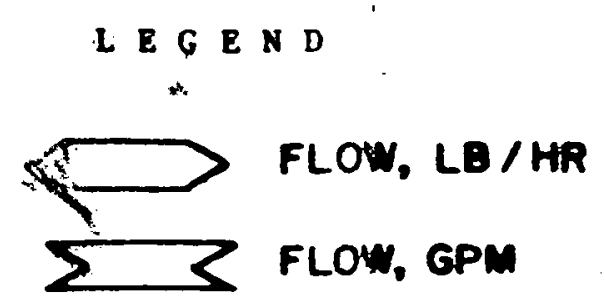

is SREA 12 SRC

1C Product Fractionstion

1D Solidification

2 AREA 13 PRODUCT UPGRADING

2B Expanded-bed Hydrocracker

3 AREA 14 CRYOGENIC SEPARATIUN

ation

4 AREA 15 GAS SYSIEYS

4 Gas Treatrent

4C Sulfur Recove

5 AREA 16 UTILITIES SA Main Substation 5B BFW Treatmen

SC Cooling Iower No. I

SD Cooling Tower No. 2

SE Power House and A1r Compressor

5F Flare

sc Liquid Thermal Oxidizer

5B Gas Incinerator

6 AREA 17 OFFSITES

6A Water Treacment

6C Wastewater Treat

6D Hazardous

te Land $f 11$

6E Non-Hazardous Haste Landfil

6F Landfill Cover Stock Pile

6G Evaporator

6H Central Control Bullding

61 Adeinistration Bullding

6J Service Change Butlding

SR Contract Maintenance Change 31 .

6L Marehouse Building

6M Maintenance Bullding

6N Stora Retention Pond

60 Ash Ponds

NOTES :
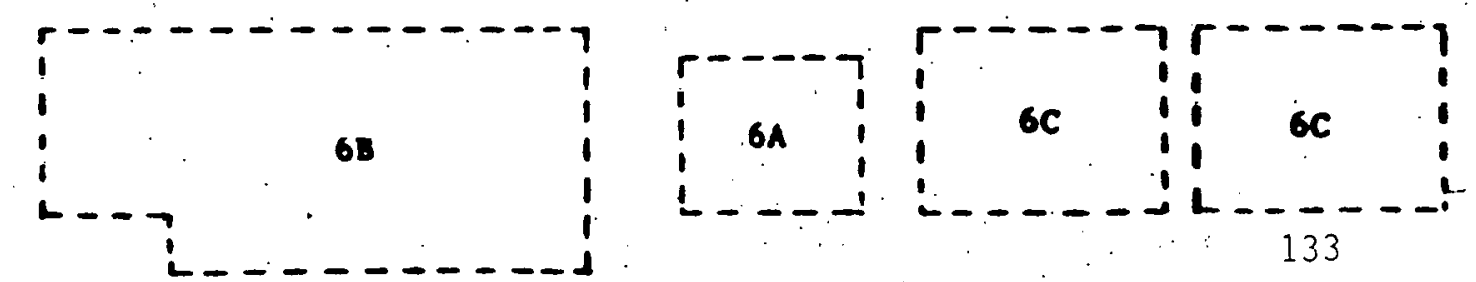

All flow rates shown are maximum flow rates.

2. Unlcas otheruise noted all pipes are C.S.

3. By belt conveyor
7 area 11 raw material a probiet STORAGE

7A Coal Storage

7 Coal Pulverizer

7D SRC/TSL Storage

8 NAPHTHA HYDRCTREAIEE 
61<smiles>ICC[IH]CCI</smiles>
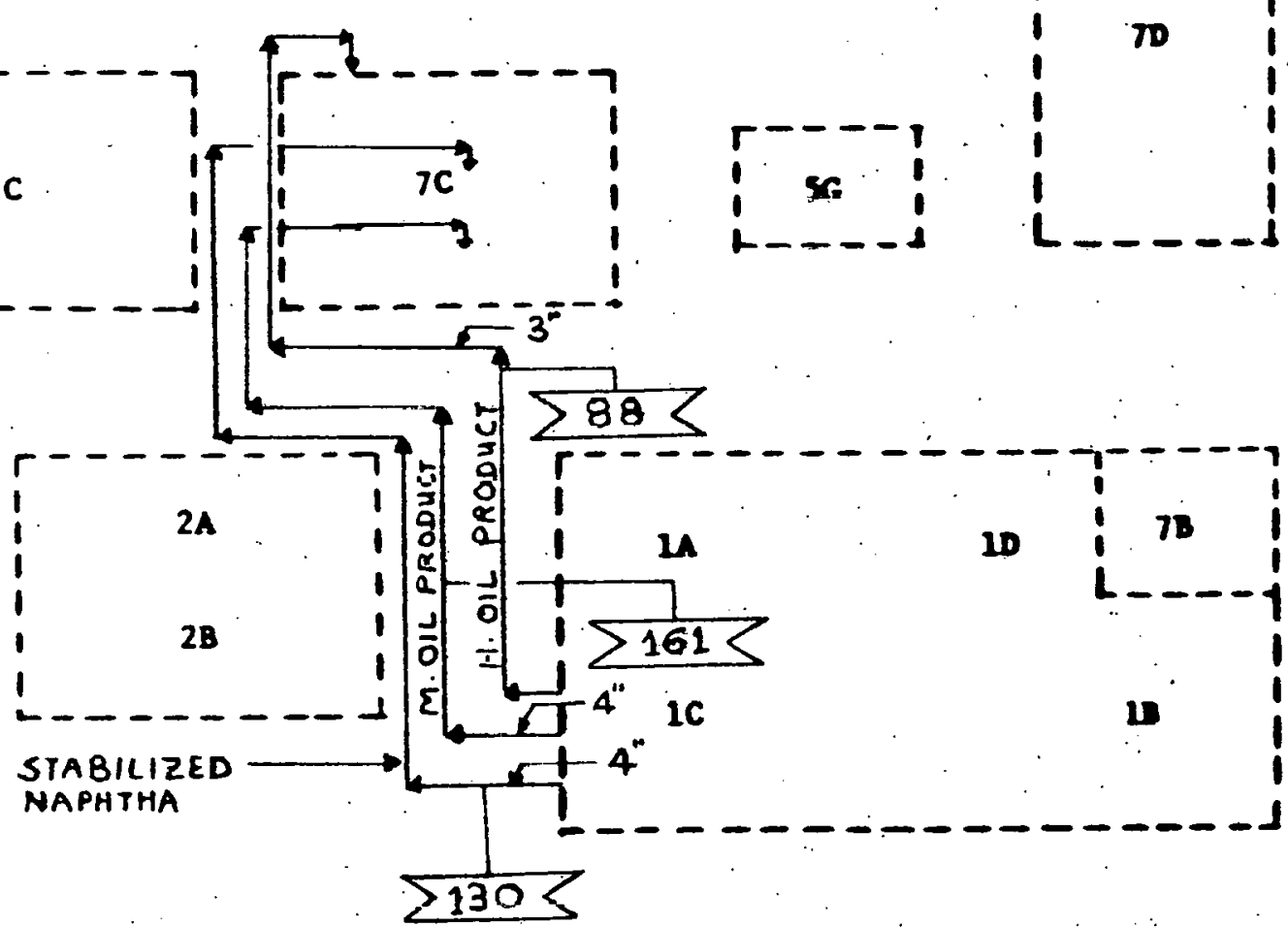

$\left[\begin{array}{c}5^{--} \\ 6 \mathrm{~J} \\ \vdots\end{array}\right]$
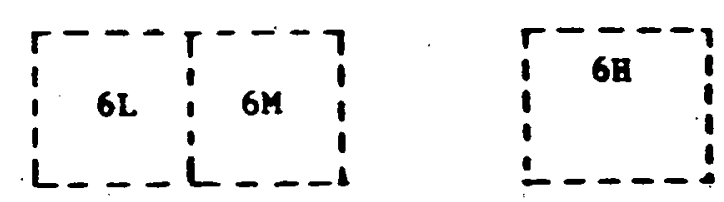

$\left\{\begin{array}{c}06 \\ -0--1\end{array}\right.$
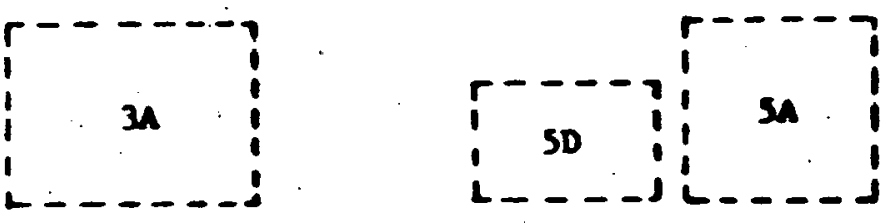

6

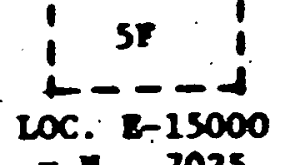

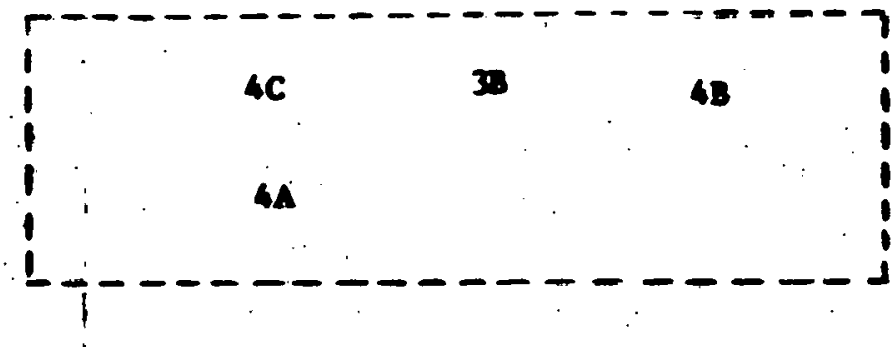
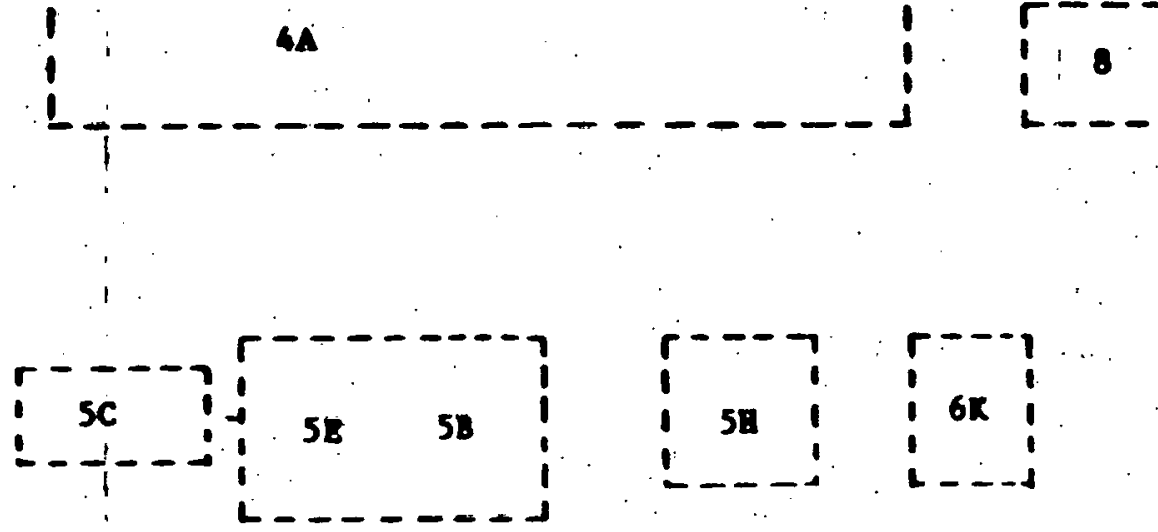

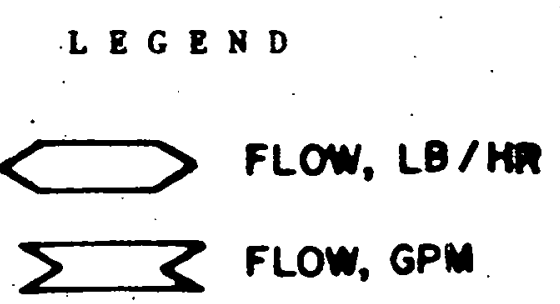

$7 \boldsymbol{A}$.
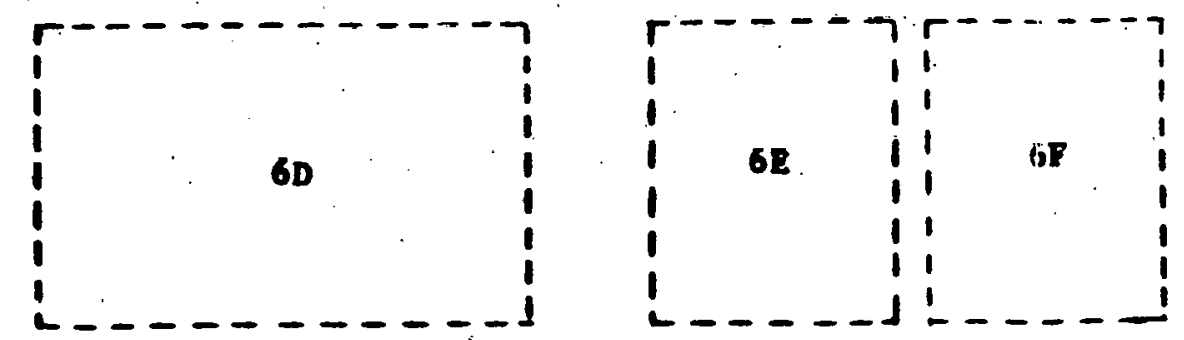

NOTES :

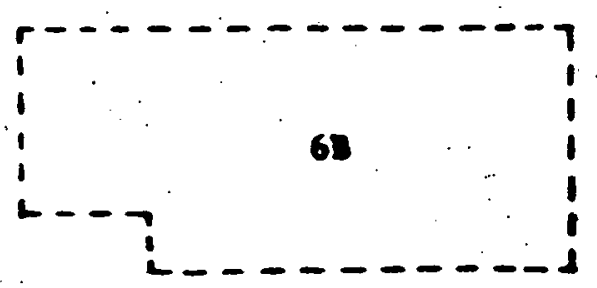

1. All flow rates shown are maximum flow rates.

2. Unless otherwise noted ill pipes are C.S.
AREA 12 SRC

in $\frac{\text { AREA PRC Process }}{2}$

18 Deashing

IC Product Fractionation

ID Solidification

2 AREA 13 PRODUCT UPGRADINC 2A Coker/Calciner

2B Expanded-bed Hydroctacker

3 AREA 16 CRYOGENIC SEPARATION

B Bydrogen Purificatio

4 AREA 15 GAS SYSTEMS

aA Gasificativi

4C Sulfur Recovery

5 AREA 16 UTILITIES

SB. BWW Treatmen

5C. Cooling Tover No. 1

5D Cooling Tower No. 2

SE Power House and AIr Compressor

SF Flare

5 Liyuld Thermal oxidizer SH Gas Incinerator

6 AREA 17 OFFSITES

6A Water Treatment

treacme:

6C Surge Basin

ED Non

6F Lindflil Cover Stoci Pile

6H Central cont

ntrol Building

6J Service Cation Bullding

KK Contract Maintenance Change Bldg.

6L Warehouse Bullding

6M. Maintenance Bulldiag

6N Storm Retention Posd

60 Ash Ponds

7 AREA 11 RAW MATERIAI \& PRODUCT STORAGE

in Coal Storage

7 B Coal Pulverizer

7D SRC/TSL Storage

8 NAPHTHA HYDROTREATEZ 


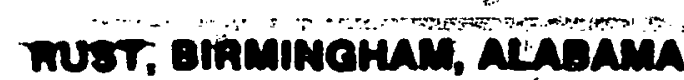

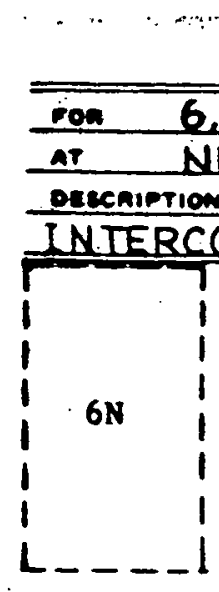
6.000 T/O SRC-1 DEM
NEWIMAN KENTUCKY

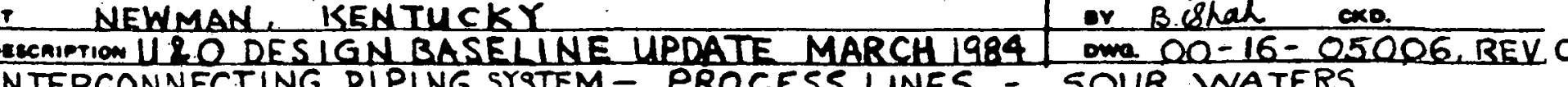

N.TERCONNECTING PIPING SYSTEM - PROCESS LINES - SOUR WATERS

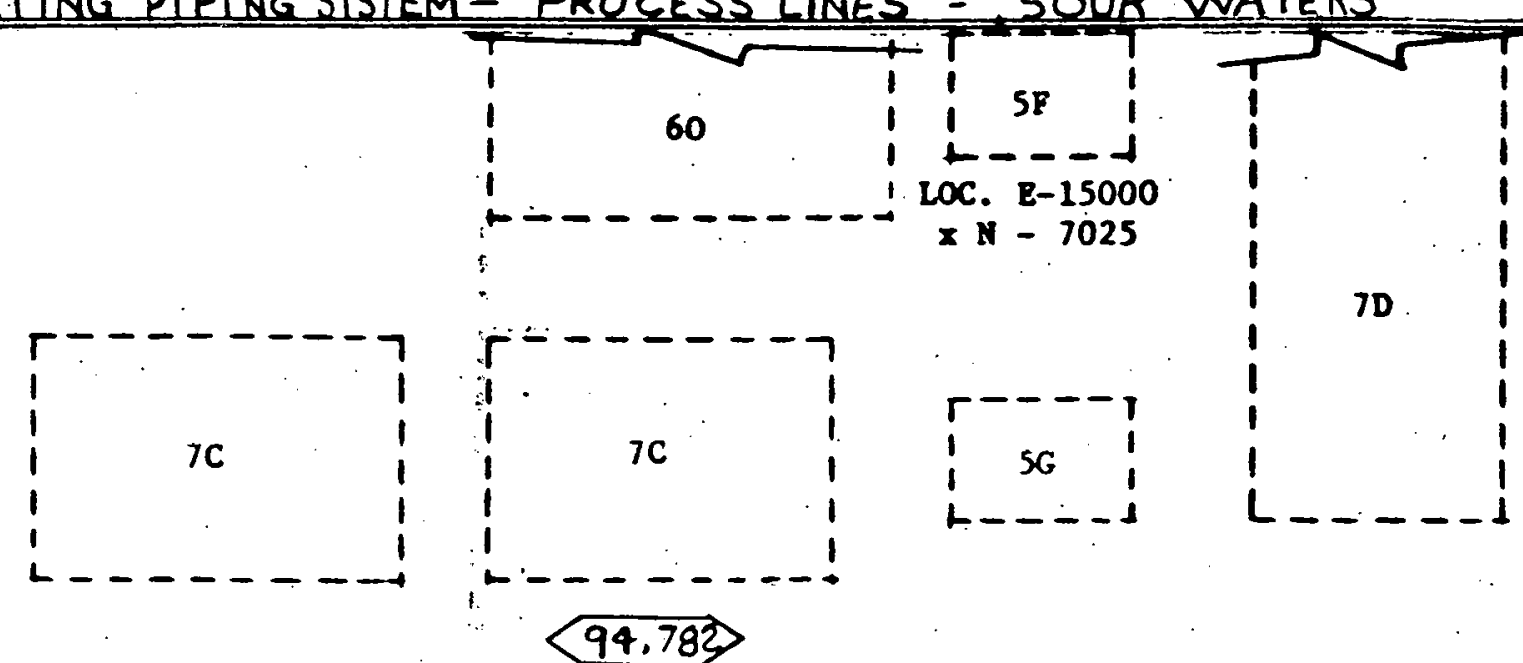

--7
61

\section{(94.782)}

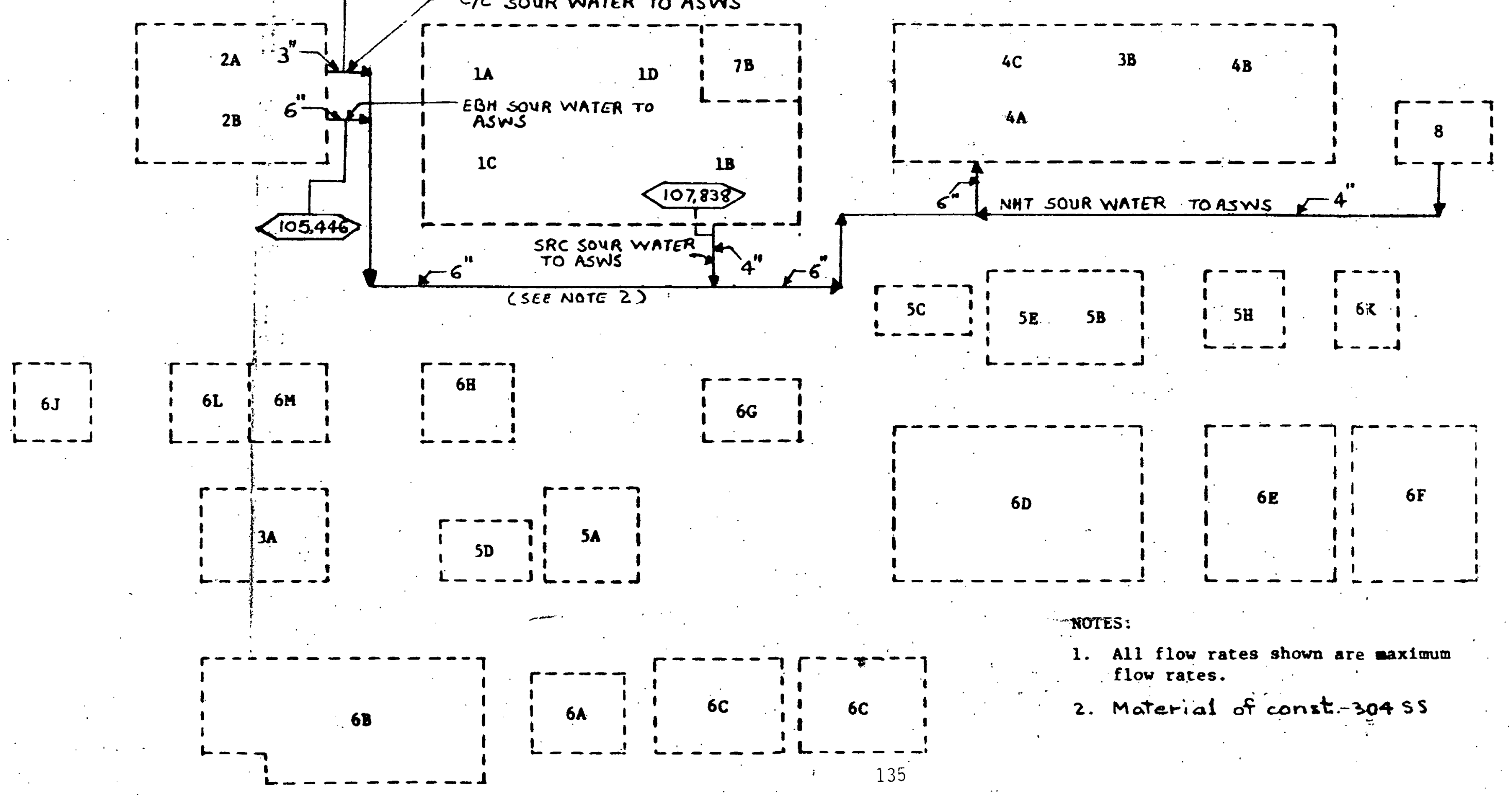

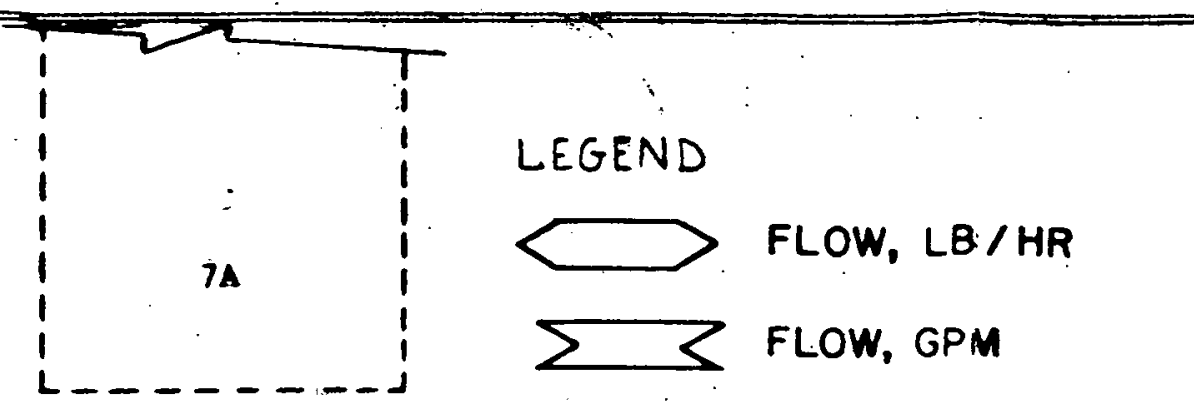

1 AREA 12 SRC

IA SRC Proce.

1B Deashing

C Product Fractionarton

ID Solidification

2 AREA 13 PRODLCT LPGRADING 2A Coker/Calcinet

Expanded-be

3 AREA 14 CRYOGENIC SEPARATION

Atregen puritication

4 AREA 15 GAS SYSTEMS

4 B Gas Trearment

$4 C$ Sulfur Recover:

5 AREA 16 UTILITIES

5 A Main Substation

SB BFN Treatment

SC Cooling Tower No. 1

SE Power House and Air Compresso

SF Flare

G Liquid Thermal Oxidizer

5H Gas Incinerator

6A AREA 17 OFFSITES

6B Wastewater Ireztient

6C Surge Basin

6E Vozrdous hasce Land $f i 1$

Ge

6G Evaporator

6H Central Control 3uilding

6I Admintstration 3uilding

6J Service Change 3uilding

6K Contract Ma1nteoance Change BId

6L Warehouse Building

6M Maincenance Builiding

6.N Storm Retent
60 dsh Ponds

7 AREA 11 RAR̈ MAIERIAL \& PRODLCT

7 A Coal Storage

78 Coal Pulverizer

TD Liquid storage

3 NAPTHA HYDROTREATER 


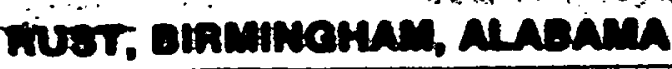
EMONSTRATION NEWMAN KENTUCK PLANT

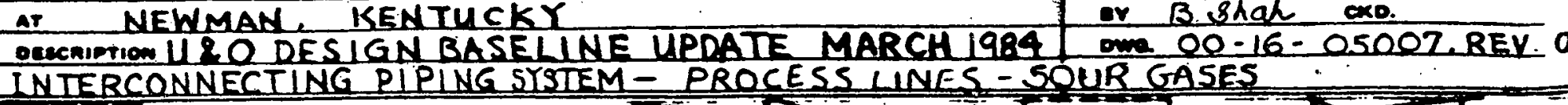
INIERCONNECTING PIPING STSTEM - PROCE SS LINES - SOUR GASES

6N
60 LOC. $\mathrm{B}-15000$ Loc. $8-15000$

7C
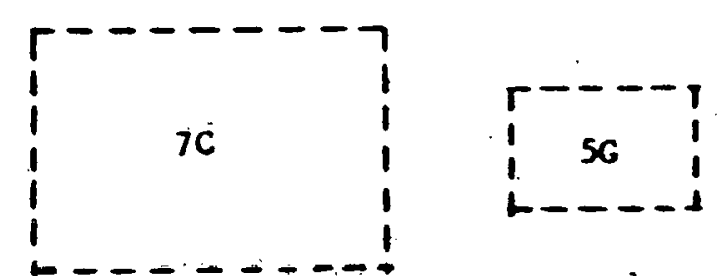

7D

$\begin{array}{lll}i & \\ 1 & & 1 \\ 1 & & 1 \\ 1 & & 1 \\ 1 & & 1 \\ 1 & & 1 \\ 1 & & 1 \\ 1 & & 1\end{array}$

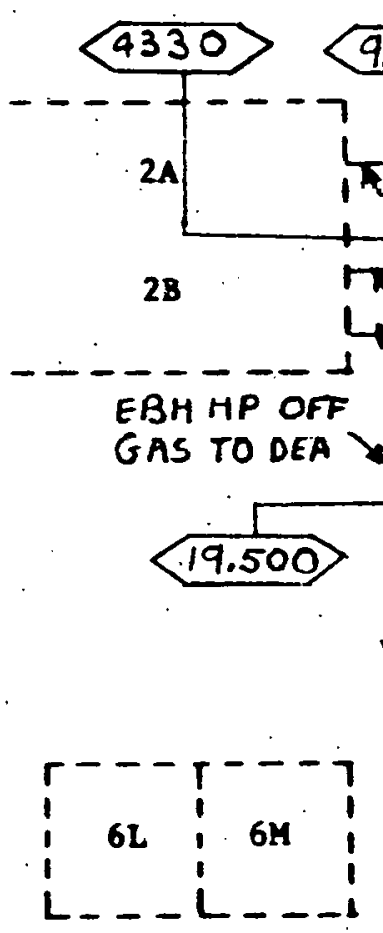

i

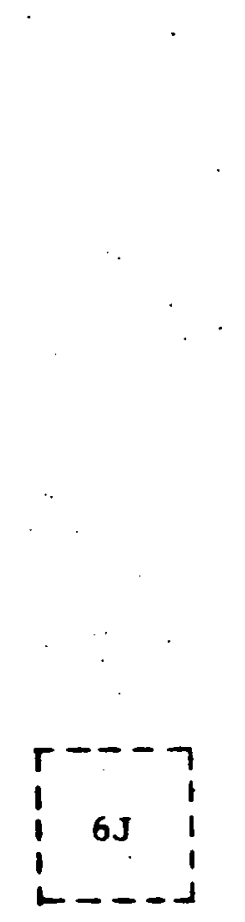
EBH LP SOUR iv iB i.

9.030 - LP COKER OFF-GAS TO DEA

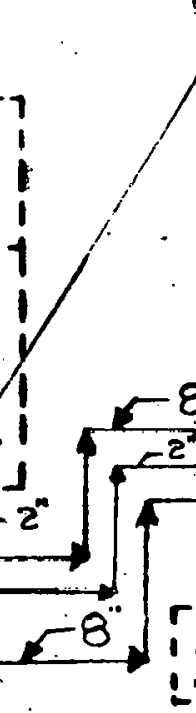

NAPHTHA FRAC. OfF GAS TO DEA

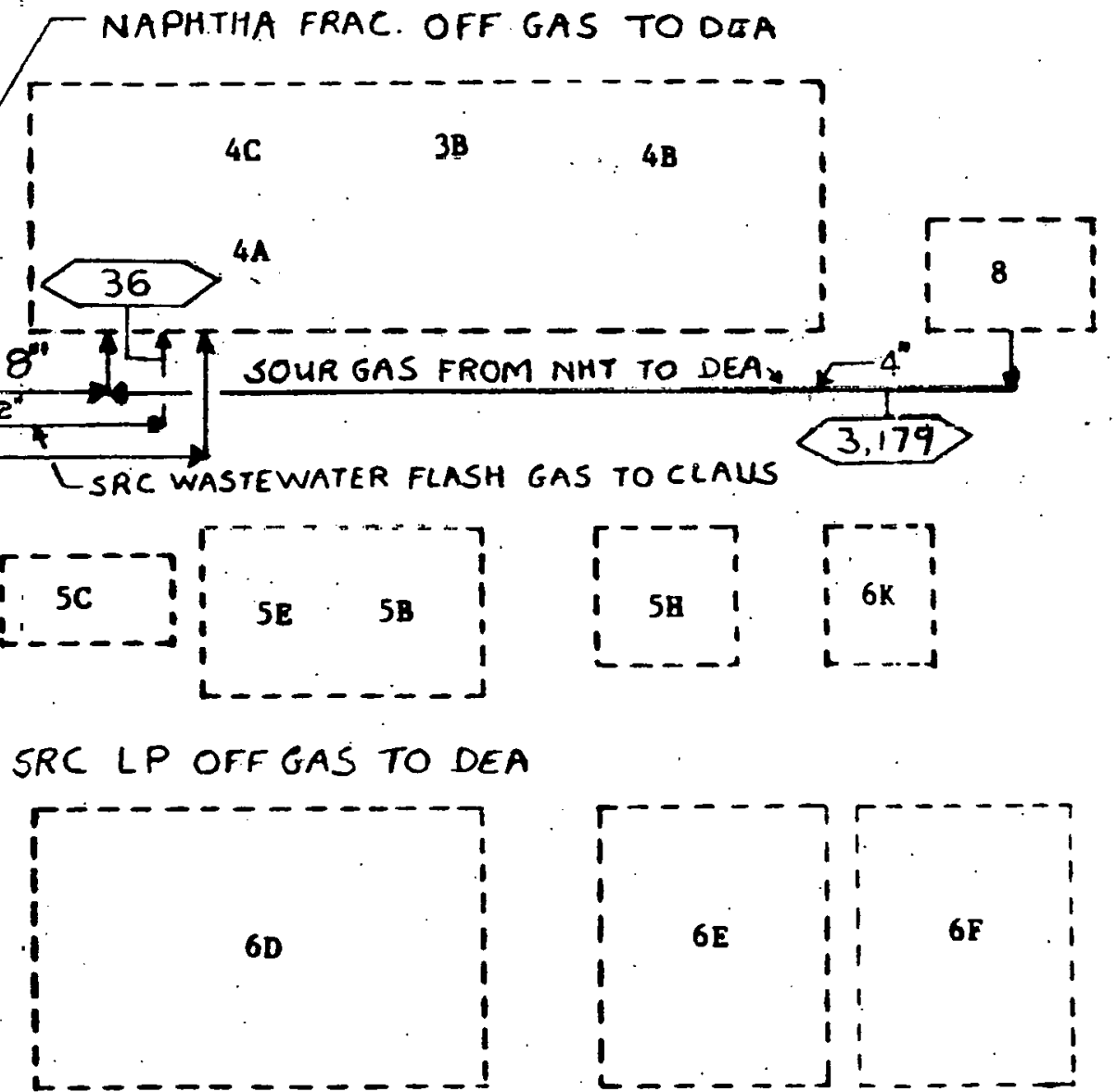

\section{NOTES:}
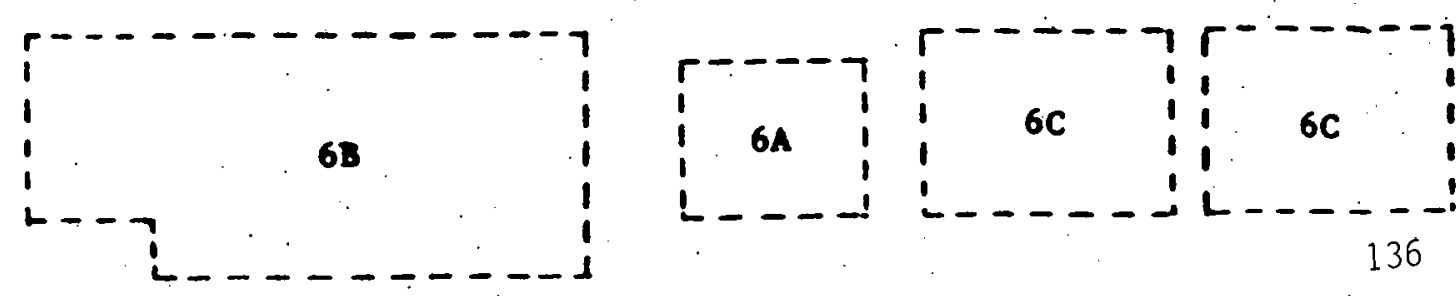

1. All flow rates shown are waximum flow rates.

2. Unless otherwise noted all pipes are C.S.
1 AREA 12 SRC

LA SRC Process

1B Deashing

Solidification

2 AREA 13 PRODUCT LPGRADING 2A Coker Caliner

3 AREA 14 CRYOGENIC SEPARATION

3B Hydrogen Purification

4 AREA 15 GAS SYSTEMS

4 A Gasification

AC sulfur Recovery

5 AREA 16 UTILITIES

SB BFW Treatmen

5C Cooling Tower No.

5D cooling Tower vo. 2

SE Power House and dir Compressor SF Flare

G Liquid Thermal oxidizer

Ill Gas Incineratur

6 AREA 17 OFFSITES

6 A water Ireatment

6B rastewater Treatzent

6D Surge Sas tr?

6E Vazardous Waste Landfill

6F Landfill Cover stock Landf ill

6C Luaporator

6H Central Control 3uilding

6 I Administration suilding

6J Service Change 3uilding

6K Contract Maintenance Change BlA,

6L Warehouse Bullding

6M Maintenance Building

60 Ash ?onds

AREA 11 RAW MATERIAL S FRODLCT. STORASE

7A Coal Storage

B Coal Pulverize

TD SRC'TSI storage

sterage

8 KAPTHA HMDROTREATER 


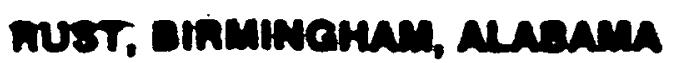
1

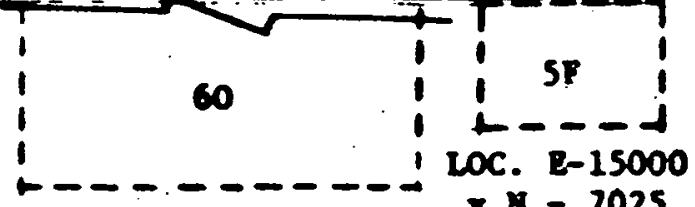
Loc. $\mathrm{E}-15000$
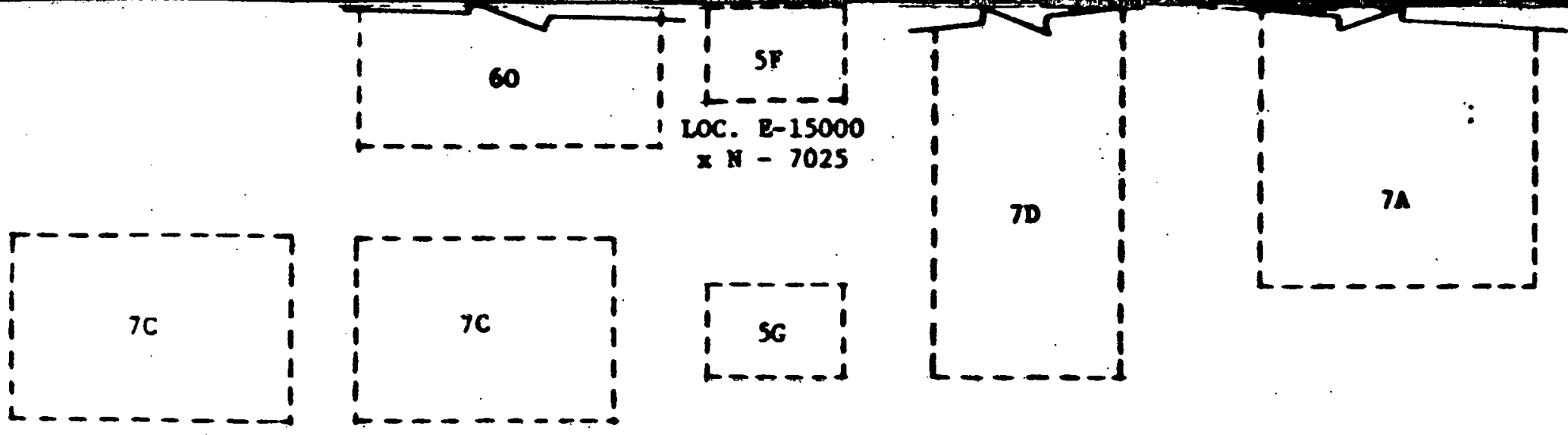

L B G E N D

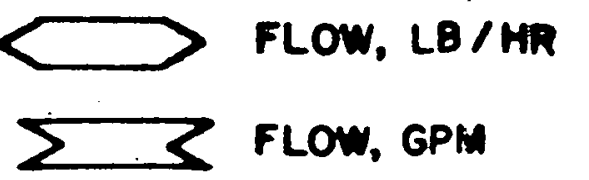

--7
161
1
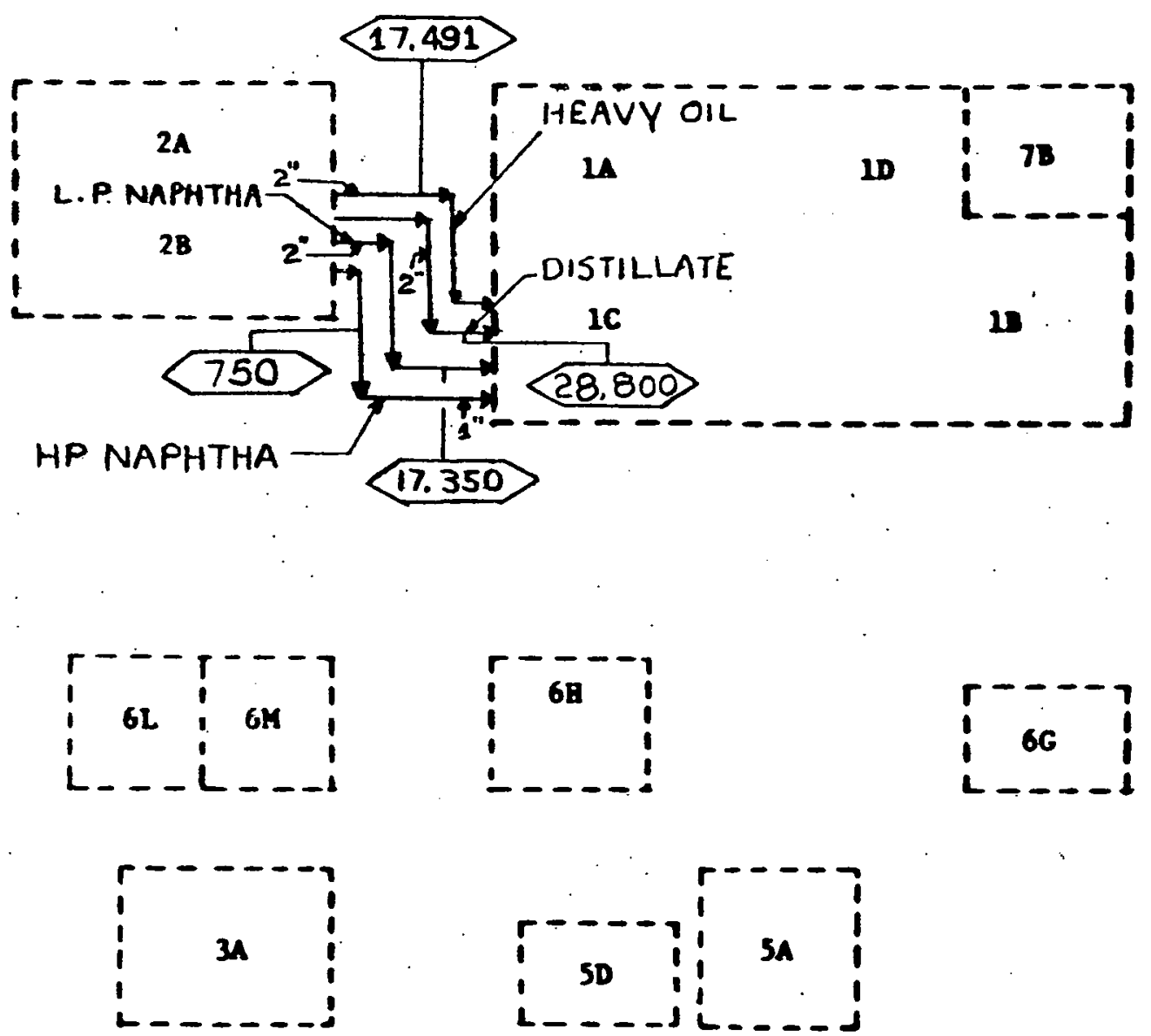
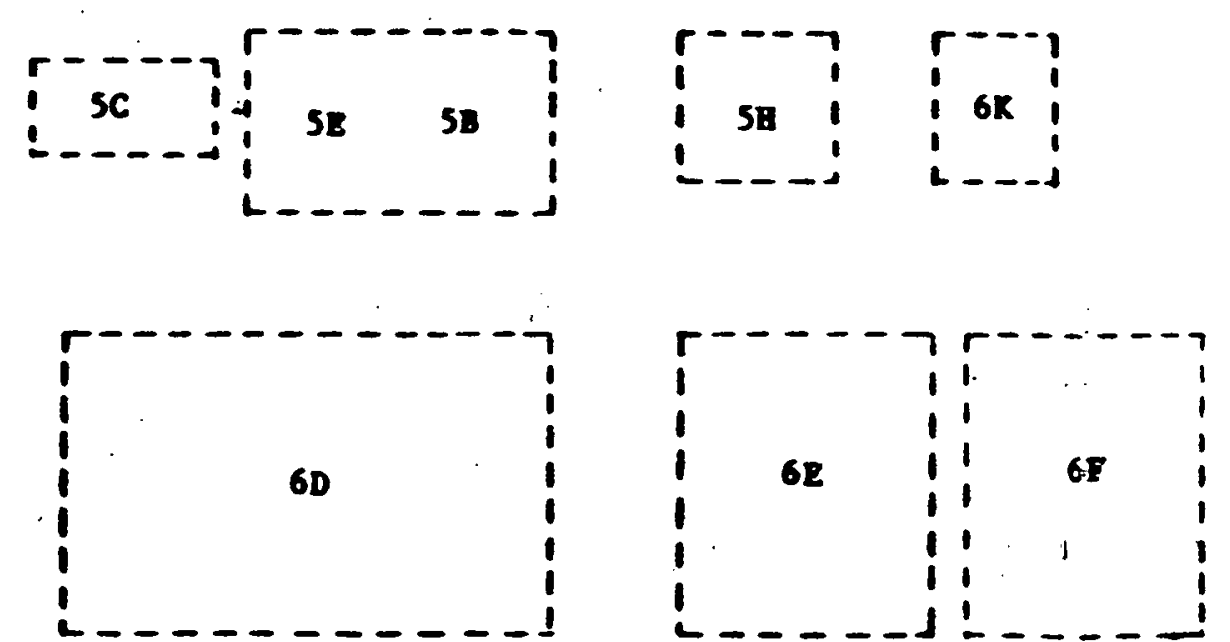

NOTES :

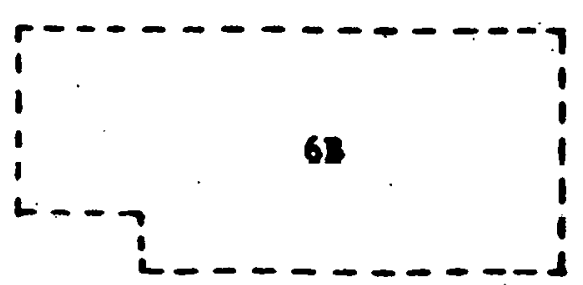

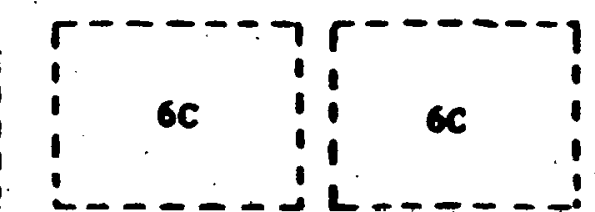

1. All flow rates shown are maximu flov rates.

2. Unless otherwise noted $\sharp 11$ pipes are C.S.
1 AREA 12 SRC

iA SRC Process

C Product Fractionaction

10 Soildification

2 AREA 13 PRODUCT UPCRADING 28 Expanded-bed Hydrocracker

3 AREA 14 CRYOGENIC SEPARATION MA Air Separation 3B Hydrogen Purification

4 AREA 15 GAS SYSTEMS

4A Gasification

4B Gas Treatment

5 AREA 16 UTILITIES 5A Main Substation

SB. BFW Treatmen

SC Cooling Tower No. 1

SD Cooling Tower No. SE Power House and AIr Compressor

Giquid Thermal Oxidizer

6 AREA 17 OFFSITES

6 A Water Treatment

6B Wastewater Treatment

C Surge Basin

Hazardous Waste Land $f$ ill

6E Non-Hazardous Waste Landf 111

6 G Evaporato

6entral Control Bullding

6I Adninistration Bullding

oJ Service Change Bullding

GR Contract Maintenance Change Bldg.

6L Warehouse Bullding

6iv Mancenance Bullding

No Storm Recention Pond

area 11 rah material product STORAG

A Coal Storage

78 Coal Pulverizer

7D SRC/TSL Storage

8 . NAPHTHA HYDROTREATER 


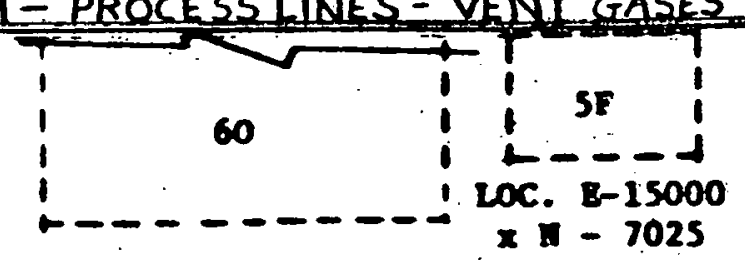
Loc. $8-15000$
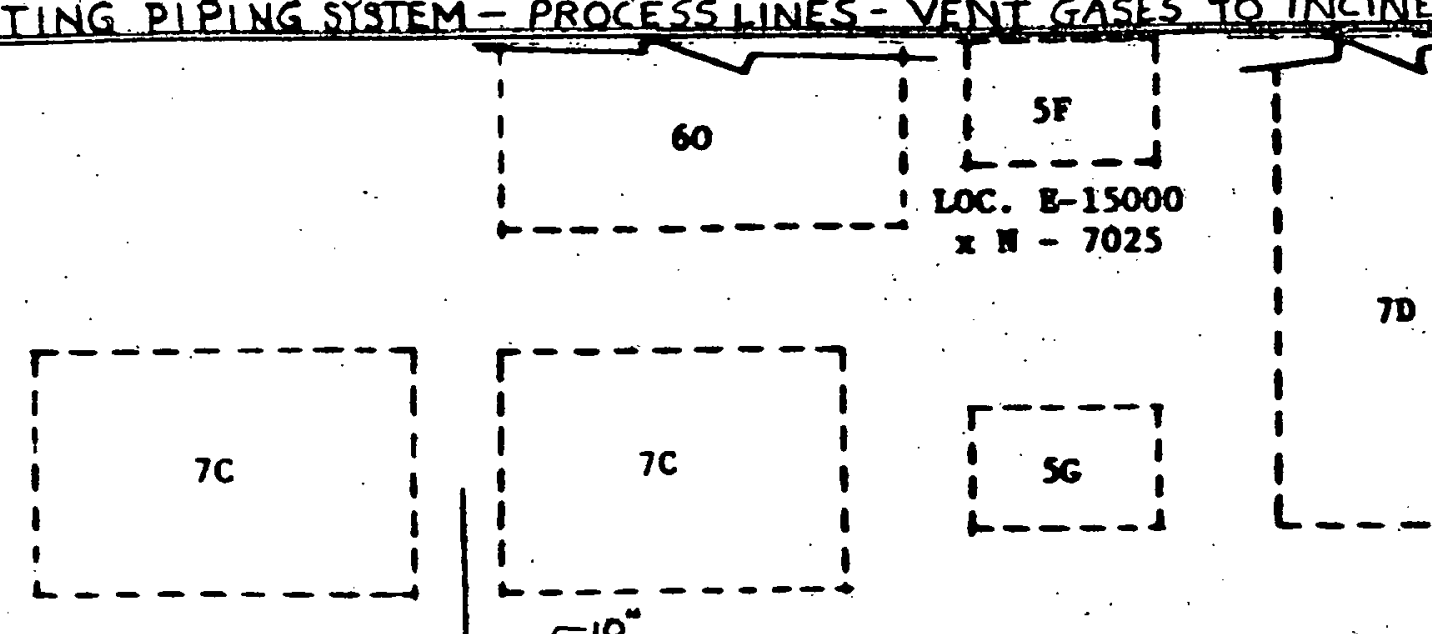
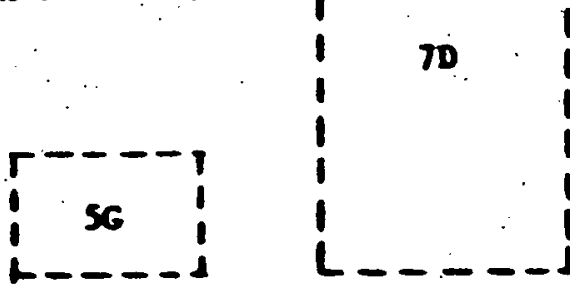

$7 A$

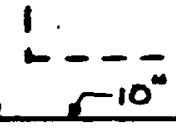

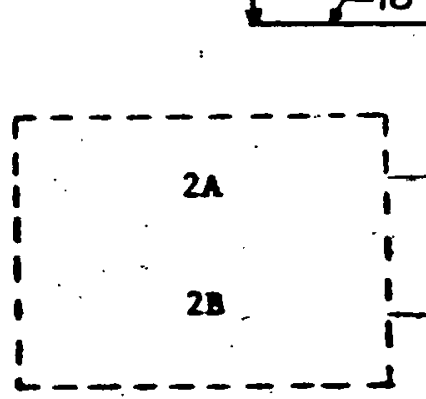

7773
: 61

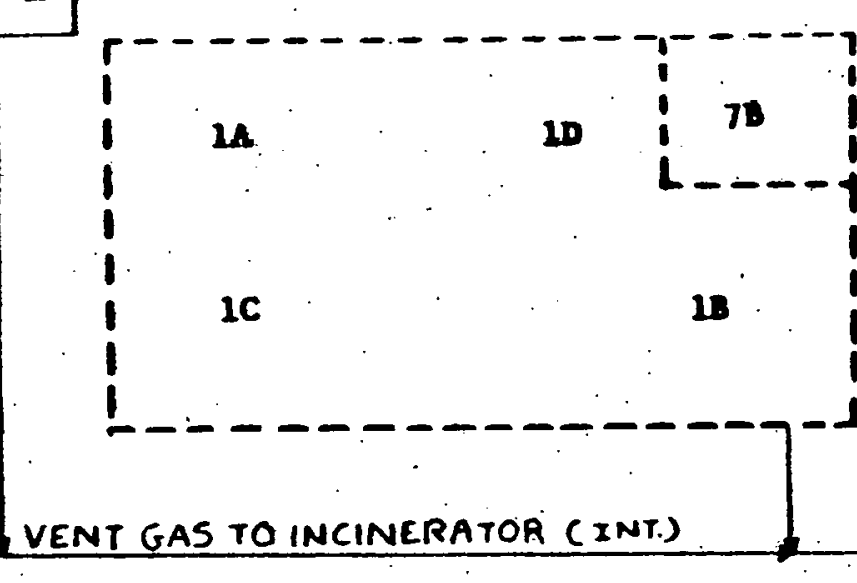

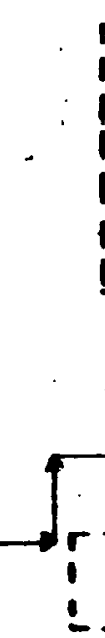

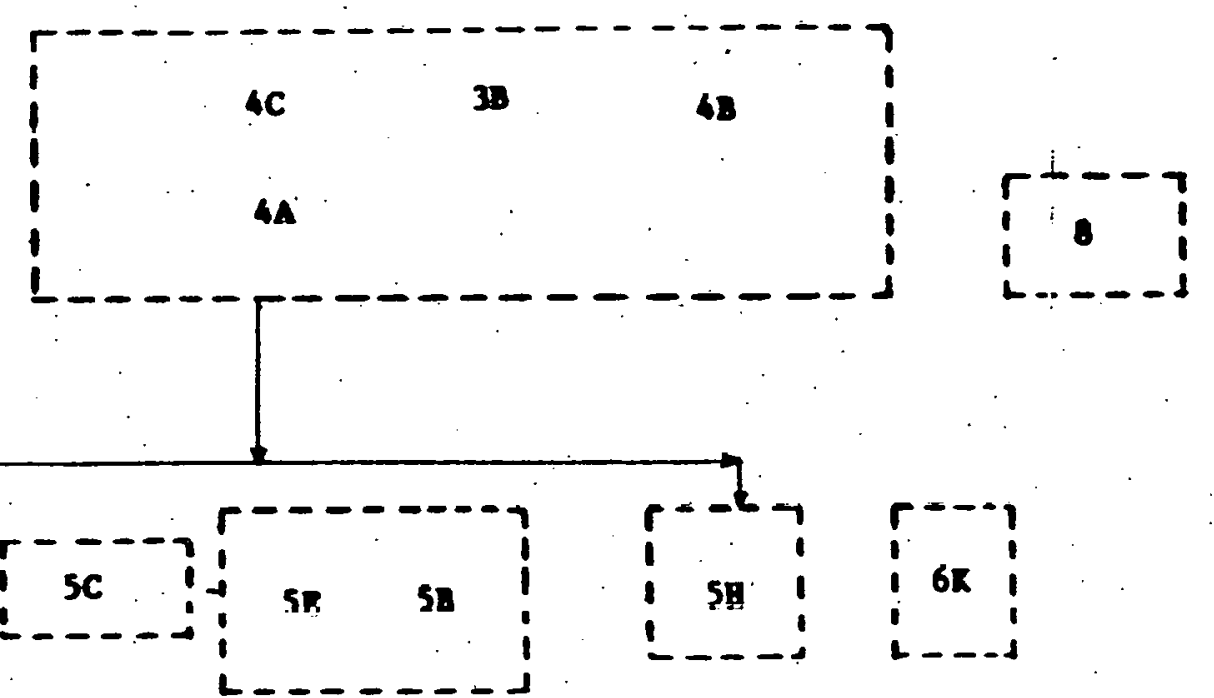

$\left\{\begin{array}{cc}r^{---} \\ 6 \mathrm{~J} \\ 1 \\ -\end{array}\right.$
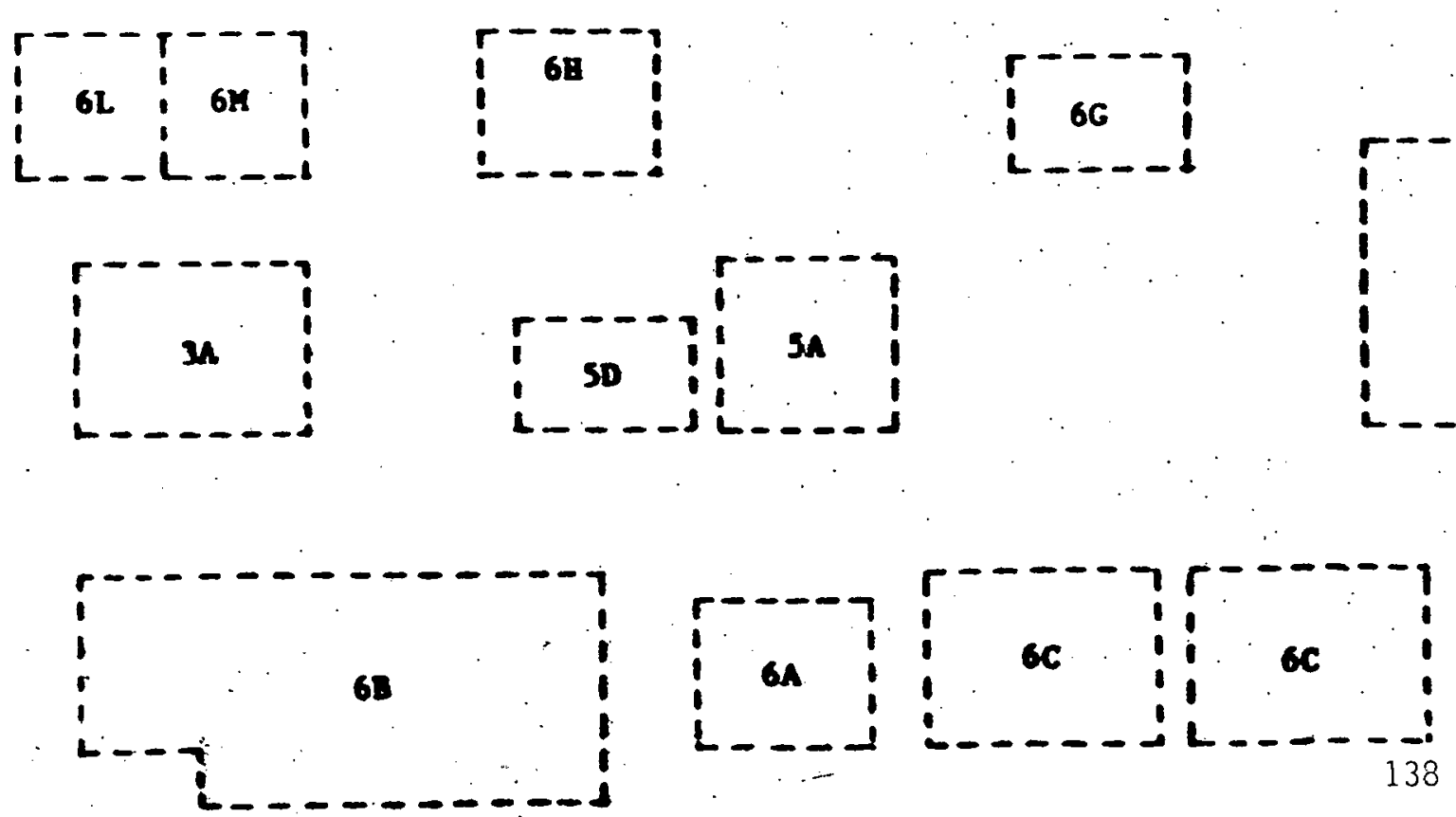

LE G E N D

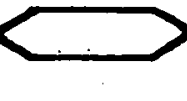

FLOW, LB / HW

FLOW. GPM
1 AREA 12 SRC

1s Deash1ng

IC Product Practionation

1D Solldification

2 AREA 13 PRODUCT UPGRADING 2A Coker/Calciner 2B Expanded-bed Hydrocracker

3 AREA 14 CRYOGENIC SEPARATION

38 Hydrogen Purificarion

4 AREA 15 GAS SYSTEMS 4A Gasification

AC Sulfur Recovery

5 AREA 16 UTILITIES

SA Main Substation

SB BNW Treatmen

5C Cooling Tower No. 1

5D Cooling Tower to. 2

SE Power House and AIr Compressor

SF Flare:

S6 Liquid Thermal oxidizer

5H Gas Incinerator

6. AREA 17 OFFSITES

6A water Treatment

6B Wastevater Treatment

6D Surge Basia

6E Wand $i l 1$

GP Landfill Cover Stock P11 111

6G Evaporator

6H Central Control Bullding

61 Adainistration Building

bJ Service Change Bullding

6x Concract Maintenance Change Blag.

6L Marehouse Bullding

64 Mintenance Building

60 Ash Ponds

NOTES :

7 area 11 raw material o product STORAGE

in Conl Storage

B Coal Pulverizer

$7 D$ SRC/FSE: Storage

8 NAPHTHA HYDROTREATER 


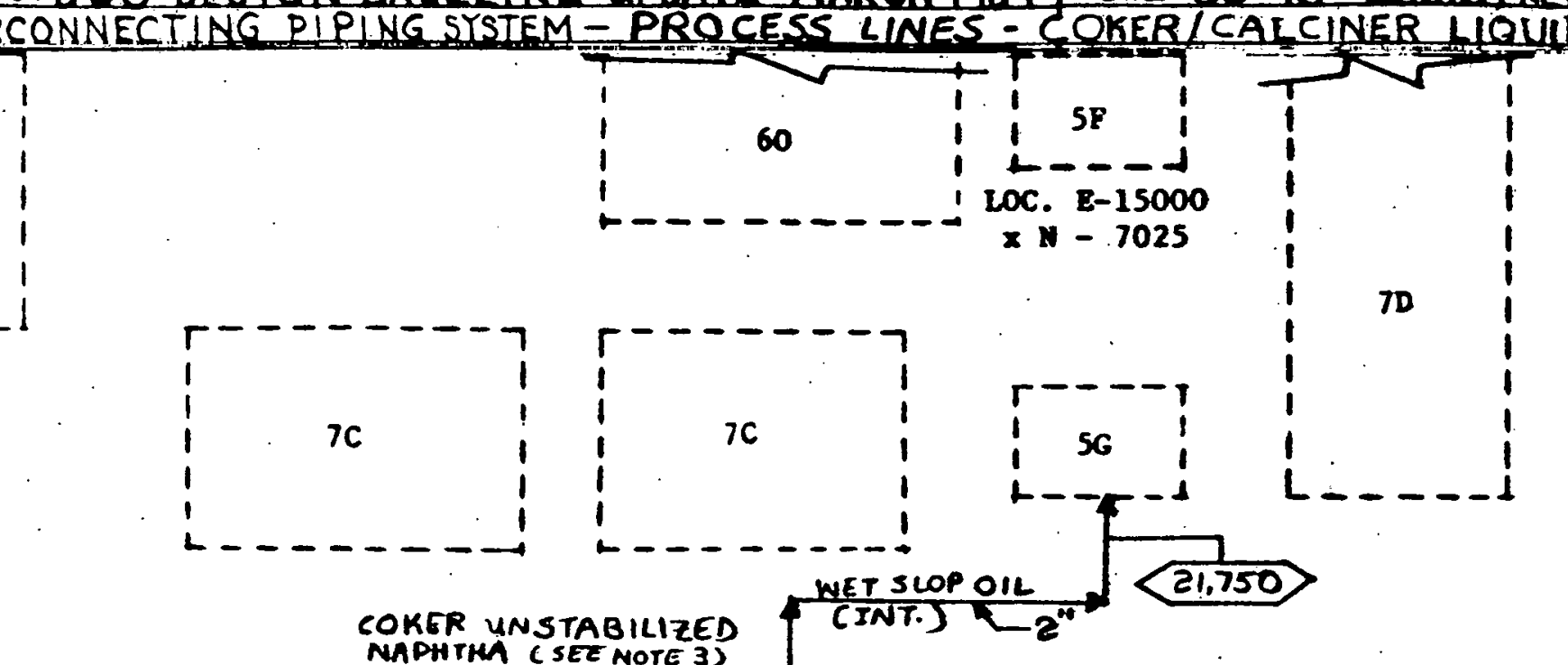

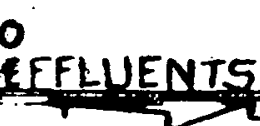

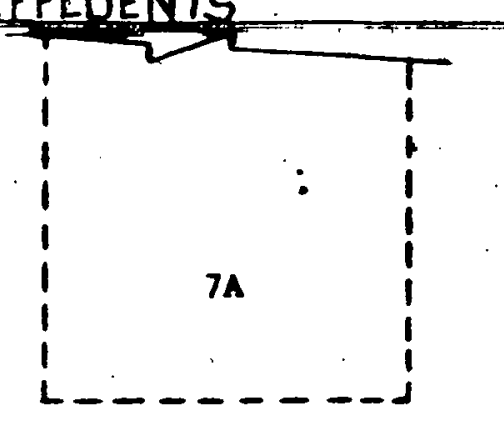

LEGENQ

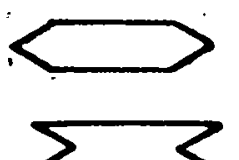

FLOW, LB / HR

FLOW, GPM
1 AREA 12 SRC

1B Deashing

1C Product Fract ionation

ID Solidification

2 AREA 13 PRODUCT UPGRADING

2A Coker/Calciner

28 Pxpanded-bed Hydrocracker 3 AREA 14 CRYOGENIC SEPARATION

3B Aydrogen Purification

4 AREA 15 GAS SYSTEMS

4A Gasification

4C Sulfur Recovery

5 ARRA 16 UTILITIES

5A Main Substation

SB Cot

5D Cooling Tower No.

SE Power House and AIr Compressor

SE Flare

56 Liquid Thermal Oxidizer

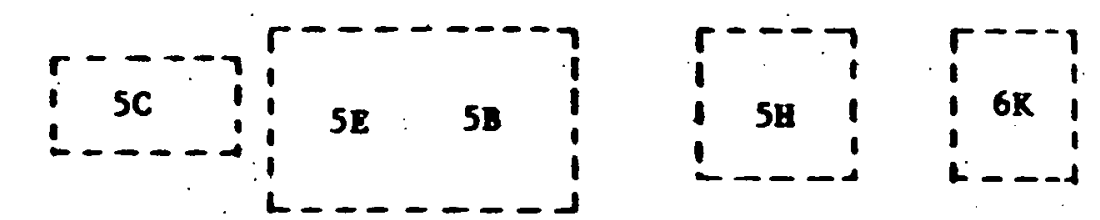

$\left[\begin{array}{c}r^{---} \\ 1 \\ 1 \\ 6 J\end{array}\right.$
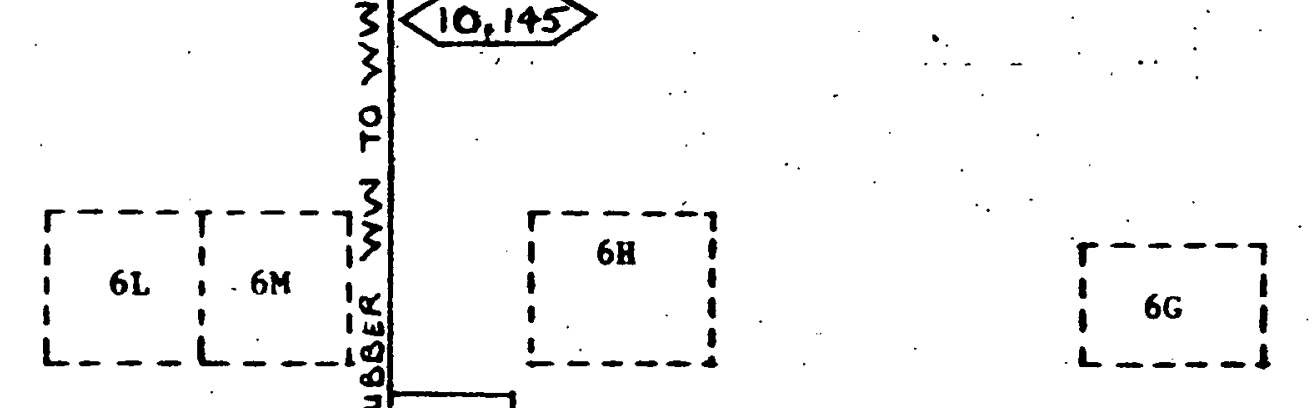

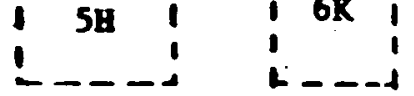
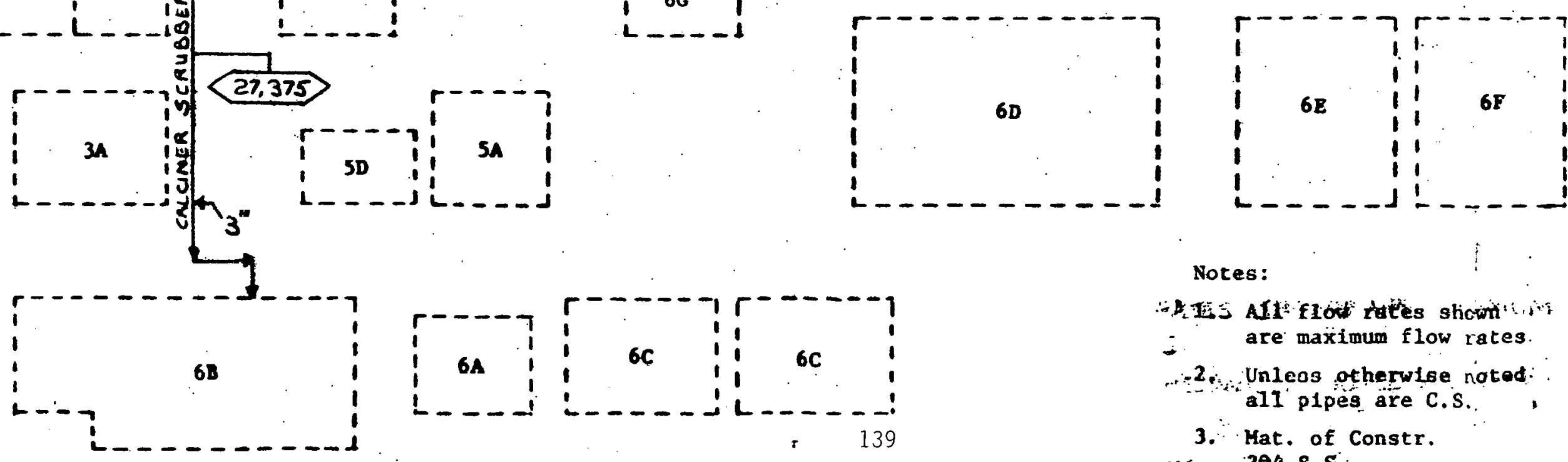

Notes:

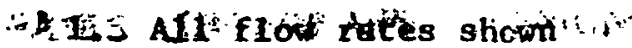

are maximum flow rates.

2. Un1eos otherwlse noted: alI plpes are c.s.

3. Mat. of Constr
5B Gas Incinerator

6 AREA 17 OFPSITES

6A Water Treatment

6 6C Hastewater

6D. Hazardous Waste Lancif11

6E Non-Hazardous Waste Landfill

66 Evaporator

6I Administration Buileing

GR Contract Maintenance Change B1dg.

6L Warehouse Bullding

6M Maintenance Buildica

68 Storm Retention Pow

60 Ash Ponds

7 AREA II RAW MATERIAL \& PRODUCT STORAGE

iA Coal Storage

78 Coal Pulverize

7c Liquid Storage

7D SRC/TSL Storage

8 MAPTHA HYDROTREATER
Cover Stock Pil

6I Central Control Bufiding 


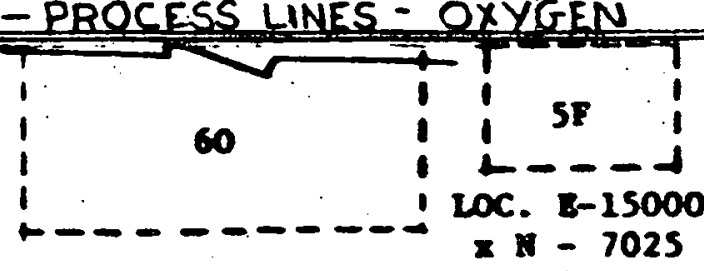
LOC. -15000 L
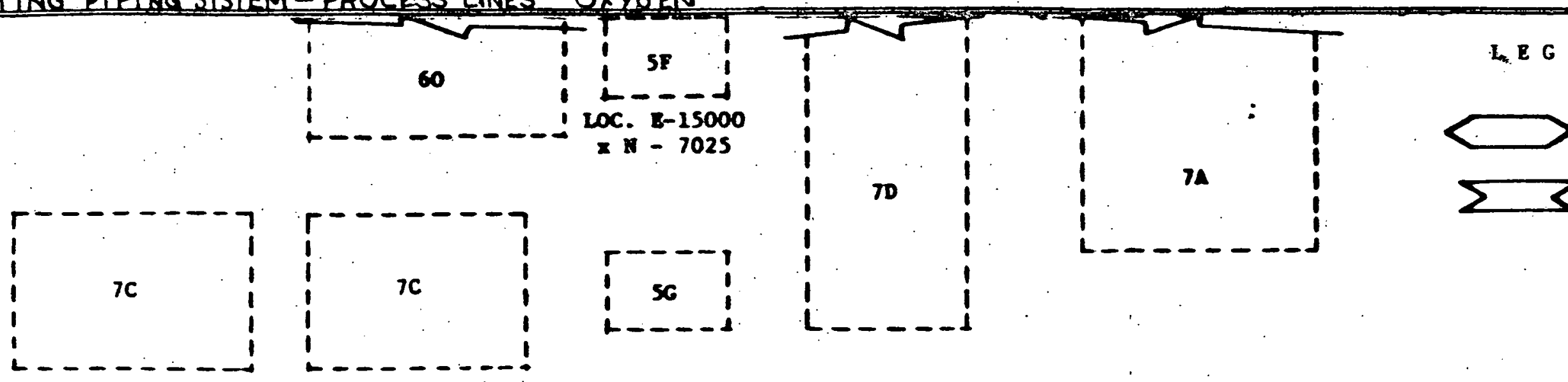

FLOW, LE/H

FLOW, GPMA $r--7$
161
1
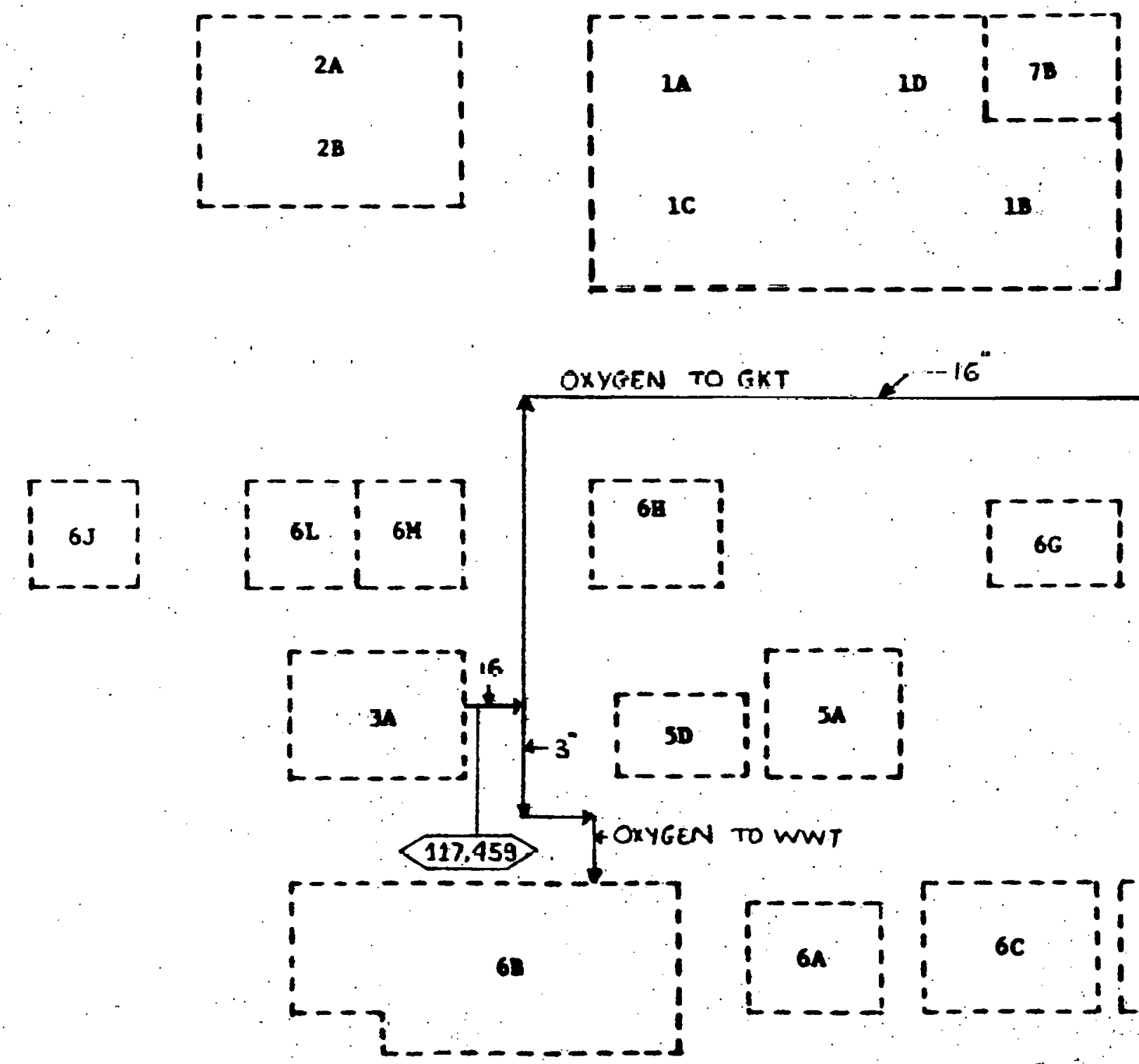

si

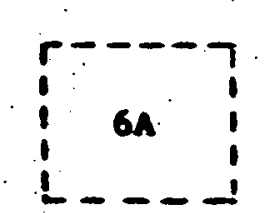

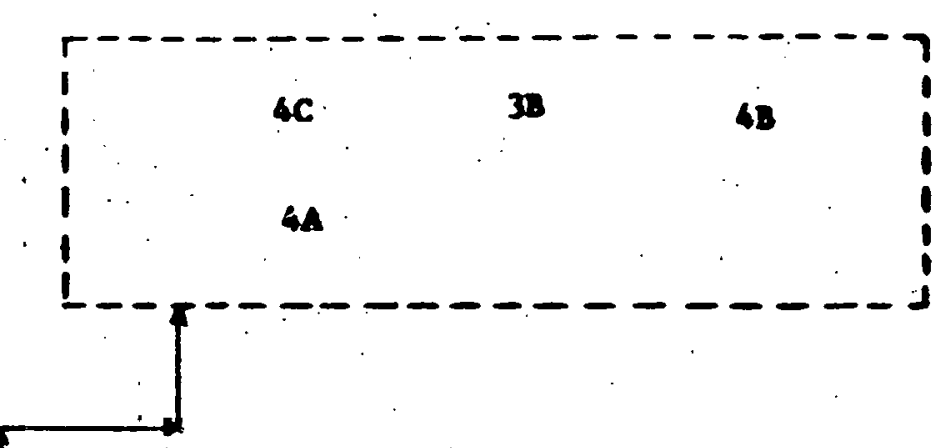

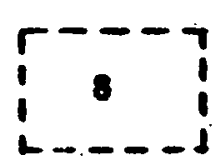

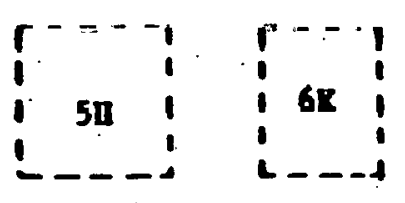

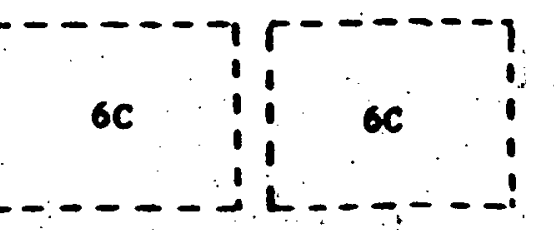

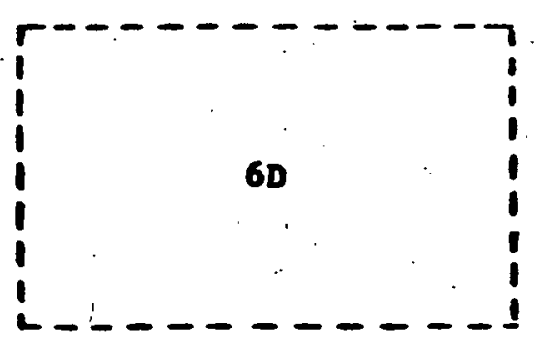

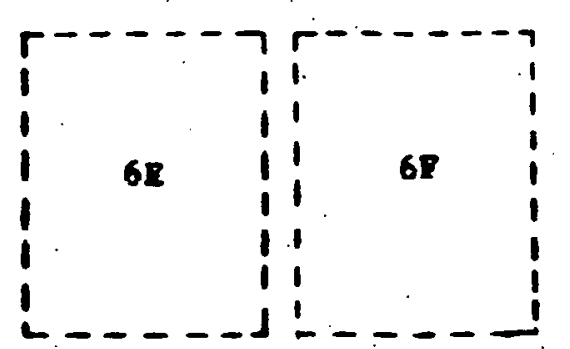

NOTES

1. All flow rates shown are maximum flow rates.

2. Unless otherwise noted all pipes are C.S.
1 ARRA $12 \mathrm{SRC}$

14 SRC Proces:

IC Droduce

act ionat 10n

2 AREA 13 PRODUCT UPGRADINC

2A Coker/Calciner

28 Expanded-bed Hydrocracker

3 AREA 14 CRYOSENIC SEPARATION 3A Air Separation

Hydrosen Purification

4 AREA 15 GAS SYSTEMS

4A Gasification

4C Sulfur Recovery

5 AMRA 16 UTILITIES

5A Main Subetation

Sc

5D Cooling lower No. 1

SE Power House and Air Compressor

SF Plare

56 Liquid Thermal Oxidizer

5H Gas Incinerator

\section{APRa 17 OFTSITES}

6 A Hater Treatment

6B Wastewater Treatment

6C Surge Basin

D Hazardous Waste Land $t 111$

6E Non-Hazardous Waste Landf111

Fandfill Cover Stock P1le

6. Evaporator

Central Control Bullding

6) Adervistration Building

ox Contract Maintenance Change Bldg.

6L Harehouge Bullding

M Malntenance Building

6r Store Retention Pond

60 Ash Ponds

7 AREA 11 RAW MATERIAL 6 PRODUCT STORAGE

7A Coal Storage

7 Coal Pulverizer

$7 C$ Liquid Storage

D SRC/TSL Storage

8 NAPHTHA HYDROTREATES 


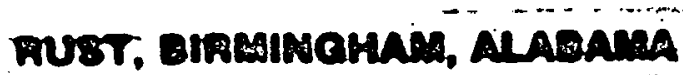

Exposina $21-2548$

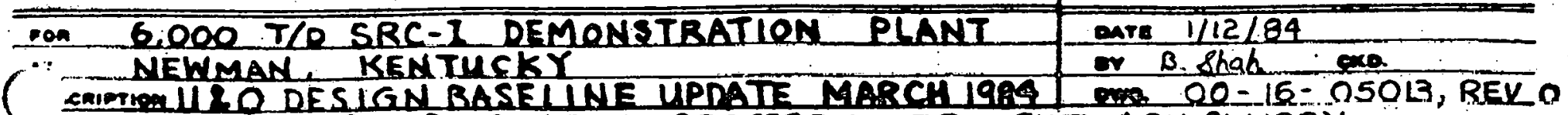

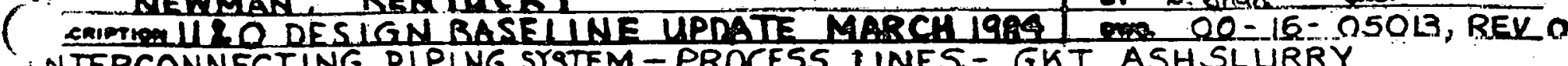

\begin{tabular}{|c|c|}
\hline \\
\hline \multicolumn{2}{|c|}{ ? } \\
\hline & \\
\hline $\begin{array}{ll}1 & 6 \mathrm{~N}\end{array}$ & \\
\hline$i$ & \\
\hline & \\
\hline
\end{tabular}

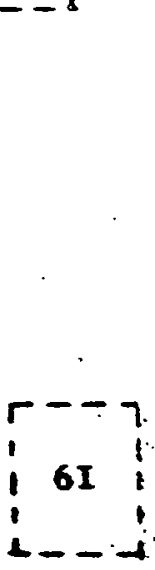

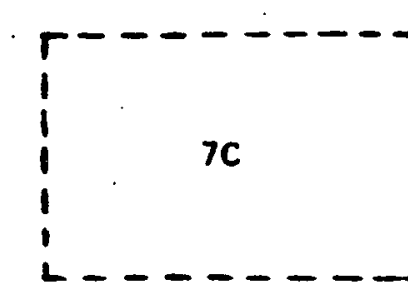
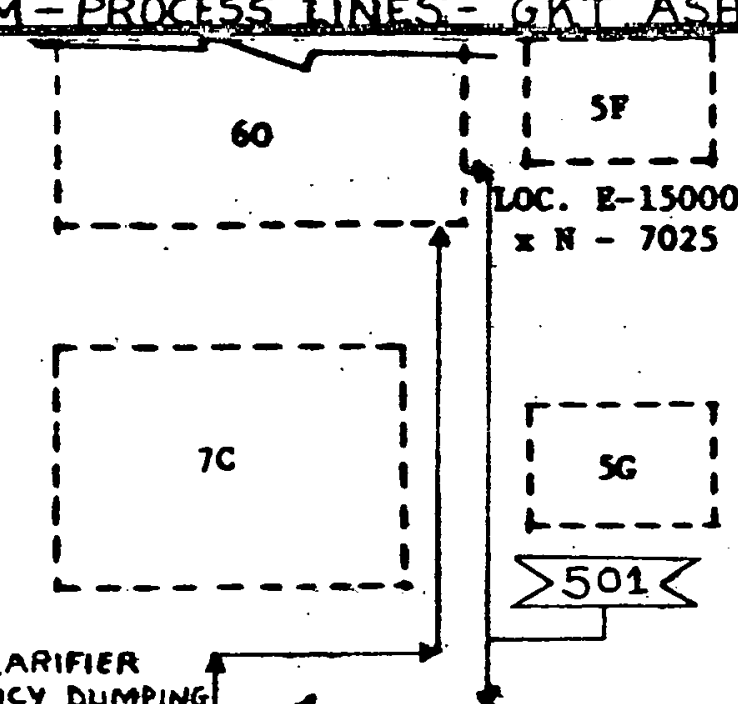

Loc. $8-15000$
$\times \mathrm{N}-7025$

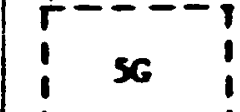

70

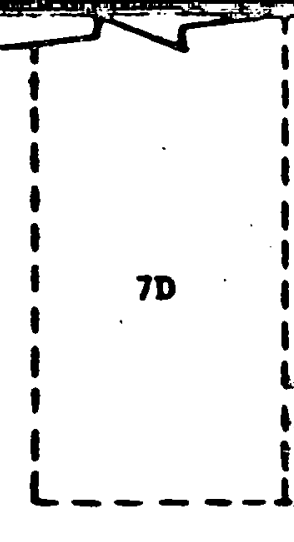

$\sum 501<$
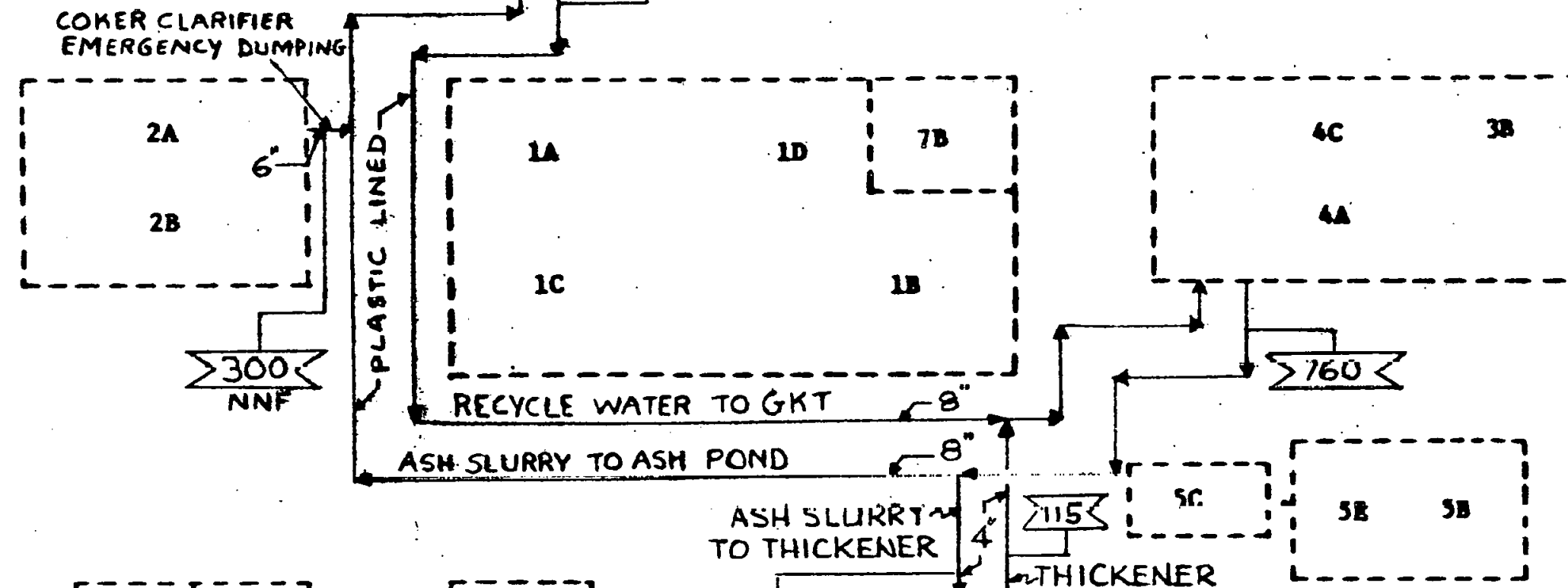

ASH SLURRTI
TO THICKENER

I135S<smiles>C1[I-][I-][IH]1</smiles>

6G

$6 \mathrm{~J}$
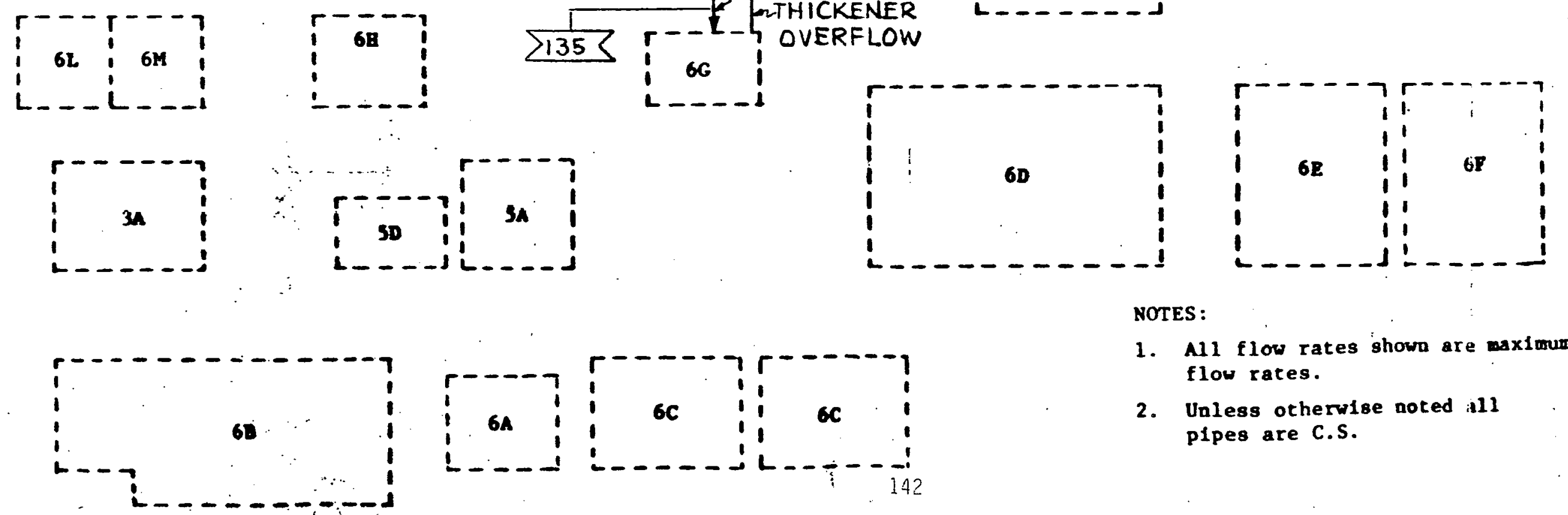

NOTES

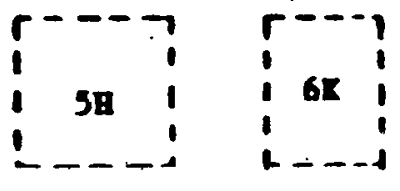

FLOW, GPM

flow rates.

2. Unless otherwise noted all pipes are C.S.
1 AREA 12 SRC

in SRC Proces

IC Product Fractionation

1D Solidification

2 AREA 13 PRODUCT UPGRADING 2A Coker/Calciner 2B Expanded-bed Hydrocracker

3 AREA 14 CRYOCENIC SEPARATION

3D Hydrogen Purification

4 AREA 15 GAS SYSTEYS

4B Gas Treatment

4C Sulfur Recovery

5 AREA 16 UTILITIES

5A Main Substation

SB BFW Treatment

SC Cooling Tower Ro. $^{2}$. 1

SE Power House and Air Compressnr

SF Flare

SG Liquid Thermal oxidizer

6 AREA 17 OFFSIIES

6B Wastewater Treatment

$6 C$ Surge Basin

6D Hazardous Waste Landf 11

6E Non-Hazardous Haste Landf 11

FF Landfill Cover Stock Pile

66 Evaporator

6H Cencral Control Bullding

61 Administration luilding

6J Service Change sullding

ox Contract Mainteance Change Bldg.

GM Maintenance Bullding

6N Storm Retention Pond

60 Ash Ponds

7 AREA 11 RAW MATERIAL \& PRODLCT STORAGE

$7 A$ Coal Storage

7 Coal Pulverizer

7D SRC/TSL Storage

8 NAPHTHA HYDROTEATER 


\section{( TERCONNECTING PIPING SYSTEM - PROCESS LINES - HYOROGEN}

6N

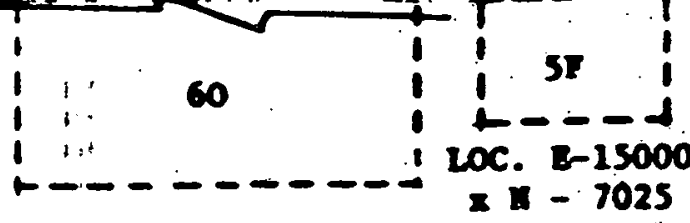

$7 C$

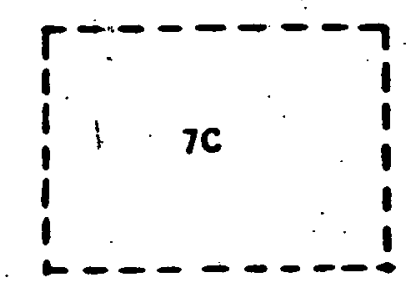

$r-27$
61
1

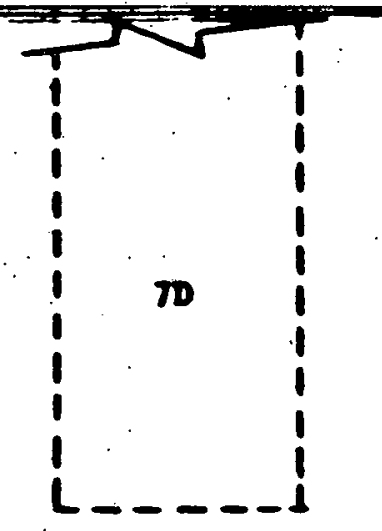

56

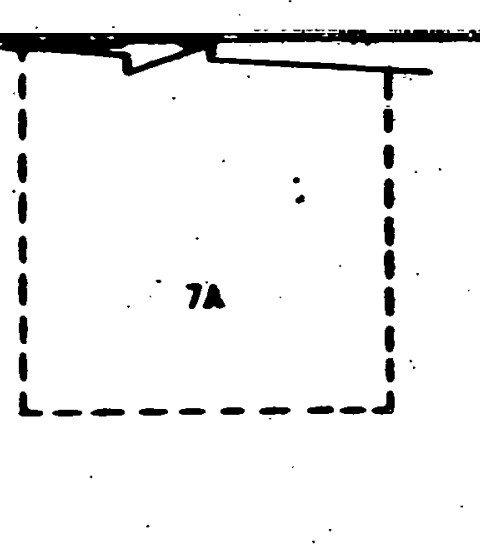

LEGEN D

$\sum$ FLOW, GPM
FLOW, LB/PR

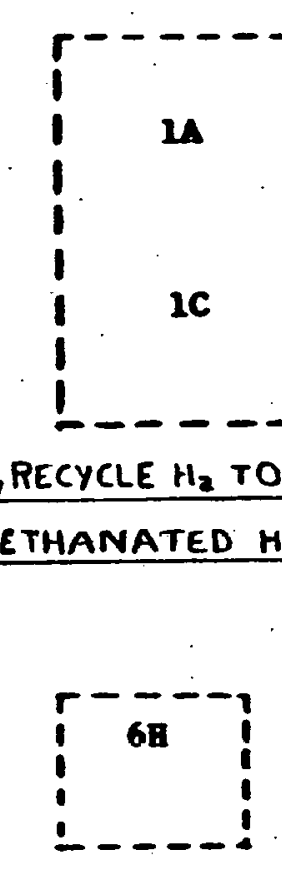

10

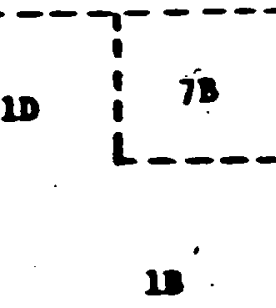

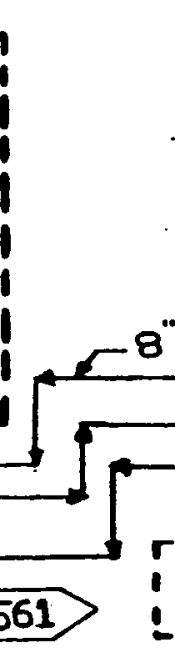

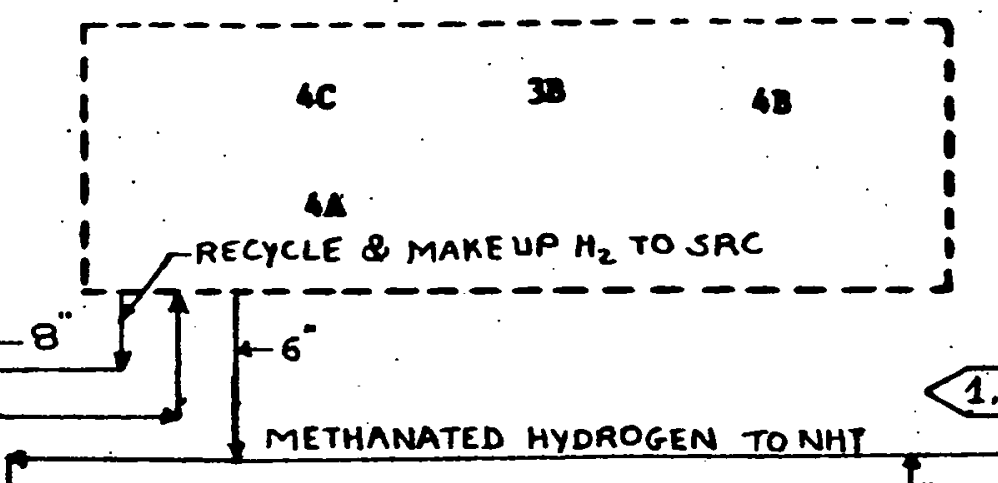

\section{i}

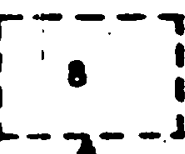<smiles>CCC</smiles>

1 AREA 12 SRC

in SRC Process

19. Product

ract:cis:: $:=3$

ID Solidification

2 AREA 13 PRODUCT UPGRADING

2B Expanded-bed Hydrocracker

3 AREA 14 CRYOGENIC SEPARATION

Air Separation

3B Bydrogen Purification

4 AREA 15 GAS SYSTEMS

AA Gasification

4C Sulfur Recovery

5 ARRA 16 UTILITIES

SA. Main Substation

Brw Treatmen

SC Cooling Tover No. 1

SE Power lower No. 2

Ir Compressor

SF Fare

Thermal oxidizer

5B Gas Incinerator

6 AREA 17 OFFSITES.

6A Water Treatment

6B Wastewater Treatment

6C. Surge Basin

6D Hazardous Waste Landfil

6E Non-Hazardous Waste Landf11

6F. Landfill Cover Stock Pile

6G Evaporator

68 Central Control Building

6I Adninistration Building

6K Service Change Bullding

62 Warehouse Bullding

6N Stortenance Butlding

60 Ash Ponds

NOTES :
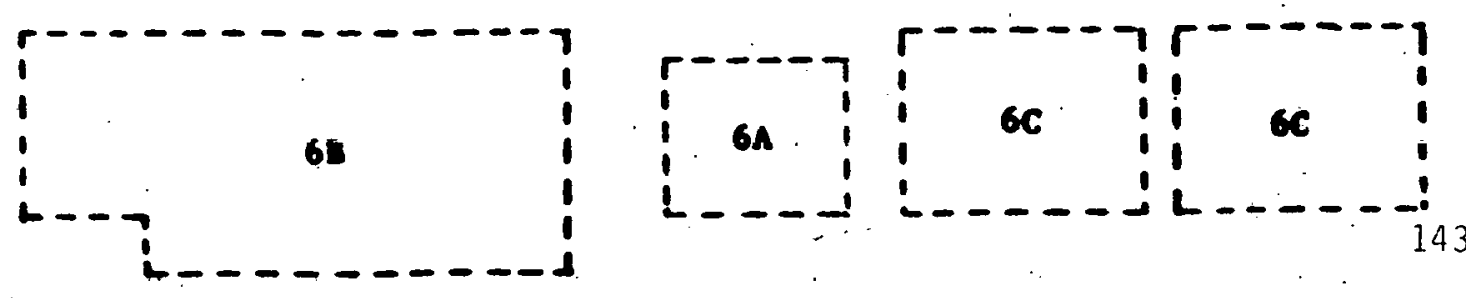

1. All flow rates showa are maximum flow rates.

2. Unless otherwise noted sil plpes are C.S.
7 AREA 11 raw material \& PRODUC? STORAGE

TA Coal Storage

7C: Cual Pulverize

7D SRC/TSL Storage

8. NAPHTHA HYDROTREATER 
mU8T, DIALAIHOMAM, ALADAMA

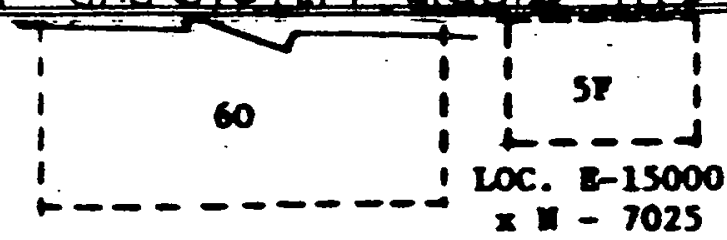

$$
\begin{array}{r}
1 \\
1 \\
1 \\
1 \\
-1
\end{array}
$$
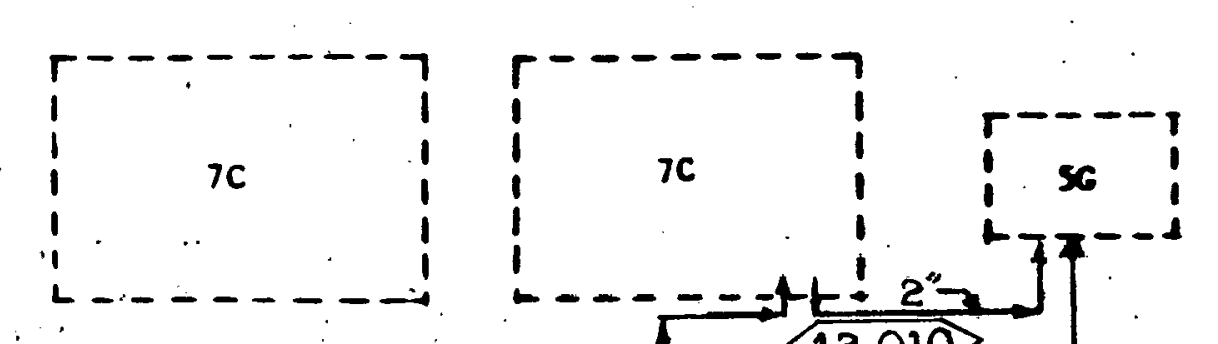

TD 12.010 INT $r-7$
161
$i--i$

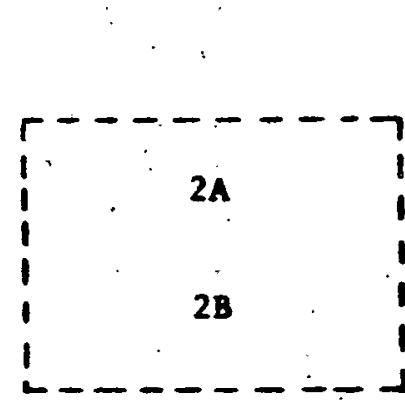

2.219

$\left[\begin{array}{c}---7 \\ 1 \\ 1\end{array}\right]$
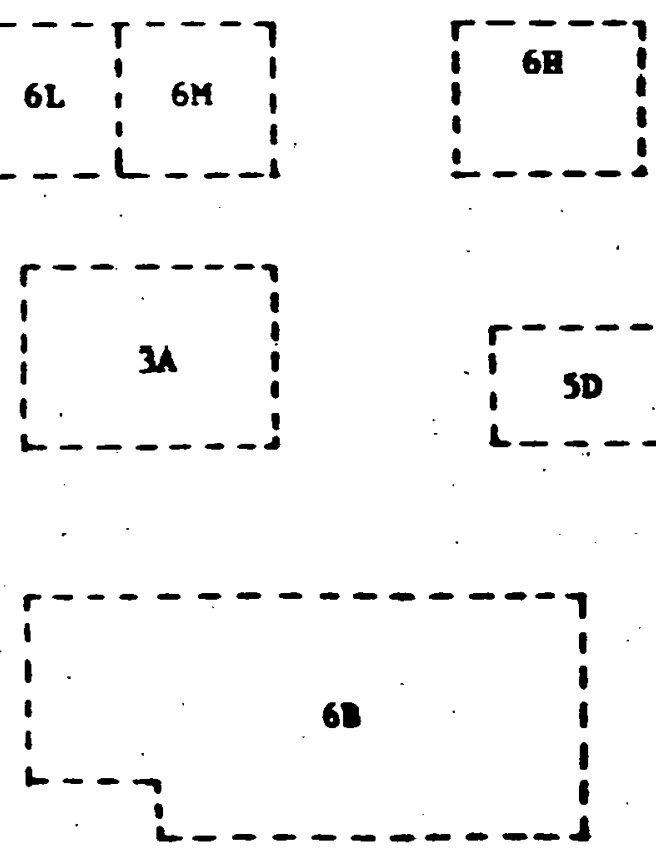

$\mathbf{u}$

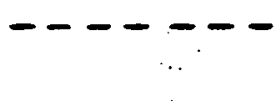

10

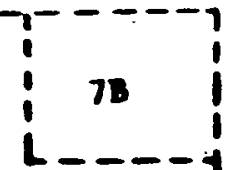

ic

(1)

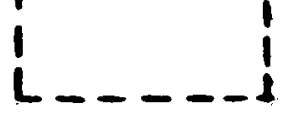

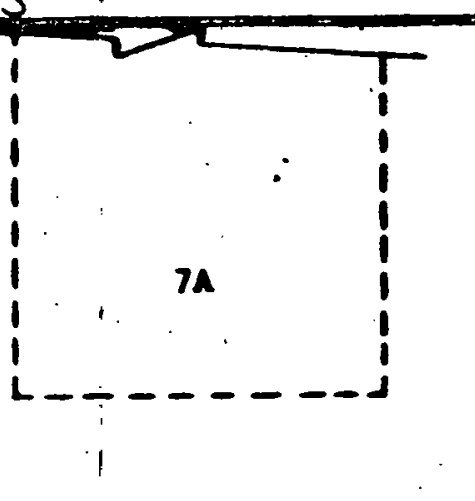

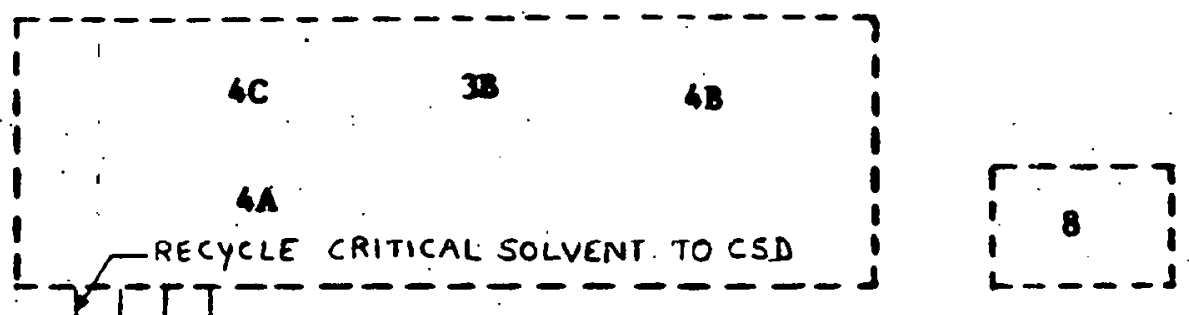

FLOW, GPA

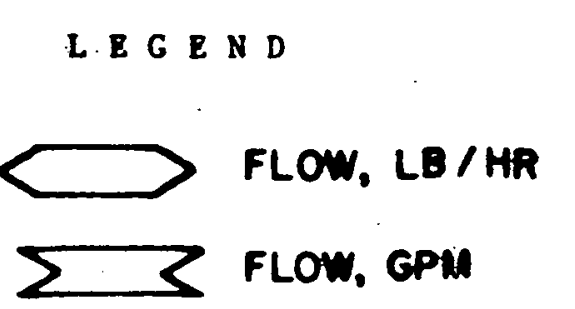

1 NREA 12 SRC

iA SRC Proces

18 Deashing

Pract lonation

10 Solidification

2 AREA 13 PRODUCI UPGRADING 2A Coker/Calciner

2B Expanded-bed Hydrocracker

3 AREA 14 CRYOGENIC SEPARATION 3B Hydrogen Purification

4 AREA 15 GAS SYSIEMS

4A Gasification

4C Sulfur Recovery

\section{AREA 16 UTILITIES}

SB PB Treatment

SC Cooling Tower No

SD Cooling Tower No.

SE Power House and A1t Compressor

SF Flare

SG Liquid Thermal oxidizer

SH Gas Incinerator

6 AREA 11 OFFSITES

6 A Water Treatment

6B Wastevater Treatment

6C Surge Basin

6D Hazardous Waste Land $f 111$

6E Landfull Cover Scock Plie

6F Landfil Cover Stock Plie

6H Evaporacor

rol Building

6J Service Chation Bullding

oK Contract maintenance thange sidg.

6L Warehouse Building

6N Stora Retention Pond

60 Ash Ponds

NOTES
1. All flow rates shown are maximum flow rates.

2. Unless otherwise noted all pipes are C.S.
7 area 11 raW Material \& PRODCET STORAGE

7 A Coal Storage

7 B Coal Pulverize

7 Ciquid Scorage

7D SRC/TSL Storage

8 NAPHTHA HYDROTREATER 


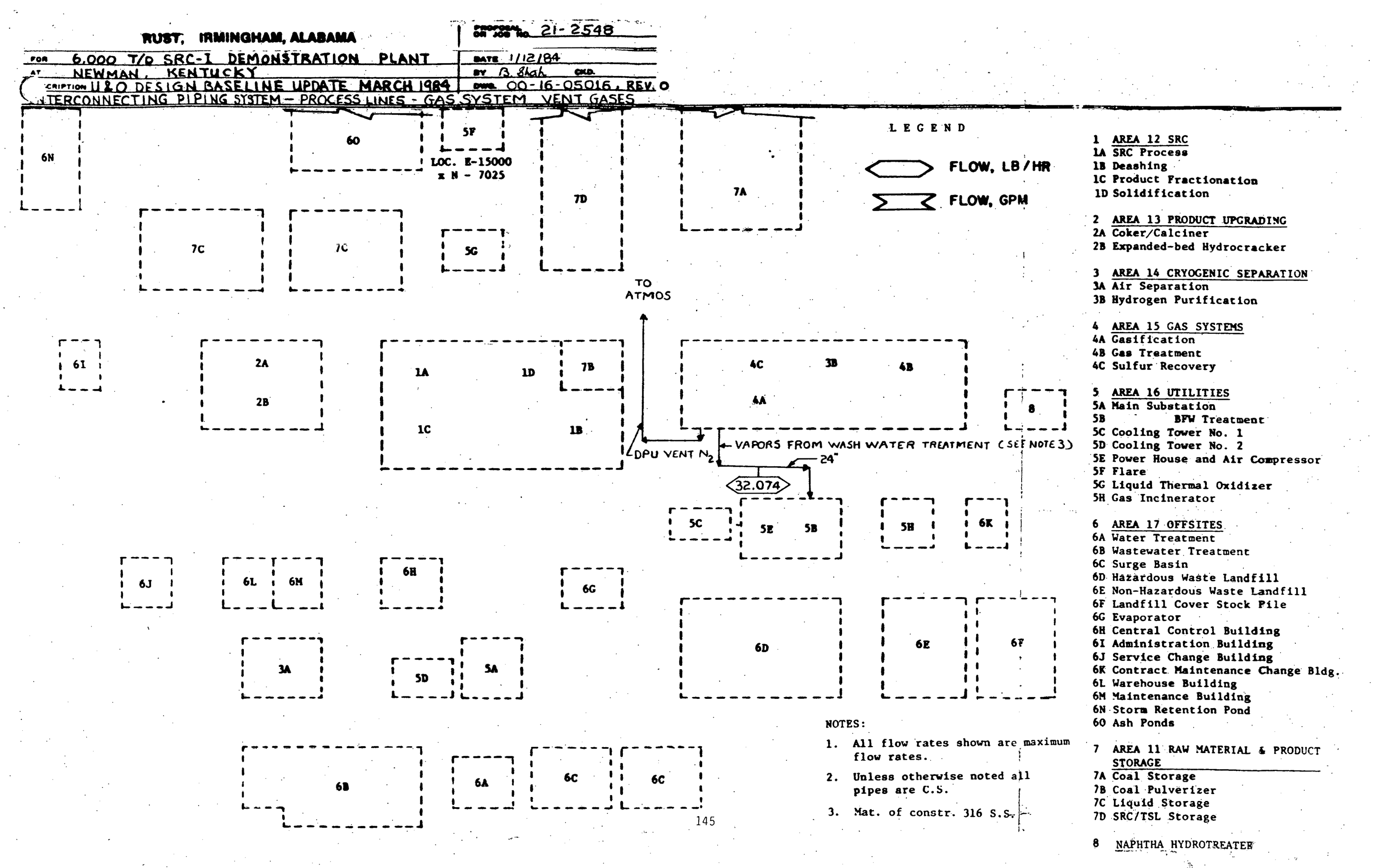




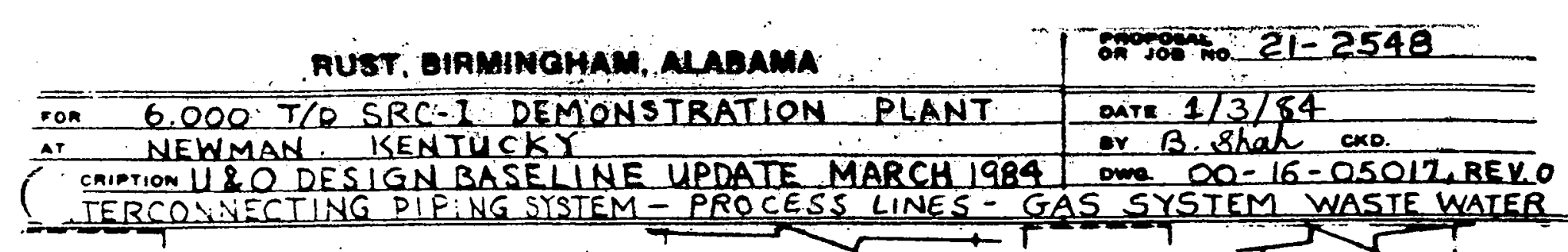

$6 \mathrm{~N}$

RCQNVIECTING PIF:NG SYSTEM - PROCESS LINES - GAS SYSTEM WASTE WATE

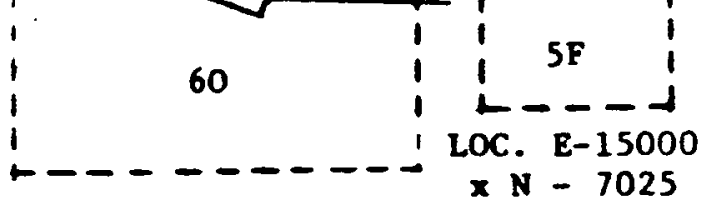

ic
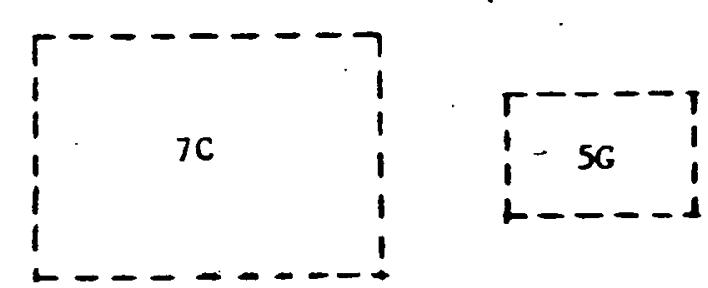

70
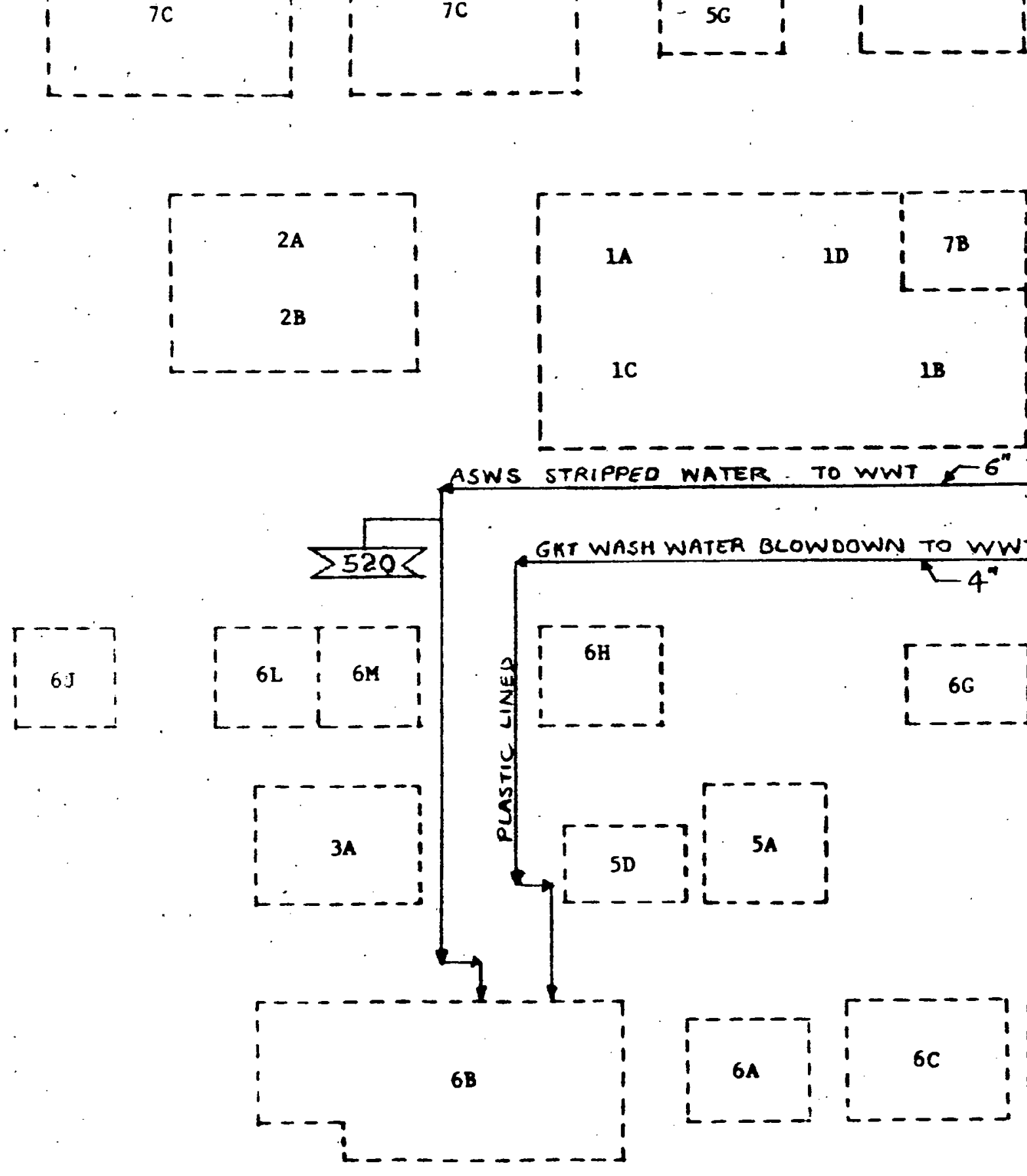

$1 \mathrm{C}$

1D

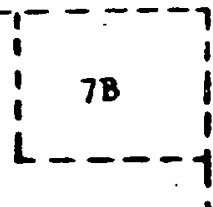

$1 \mathbf{B}$
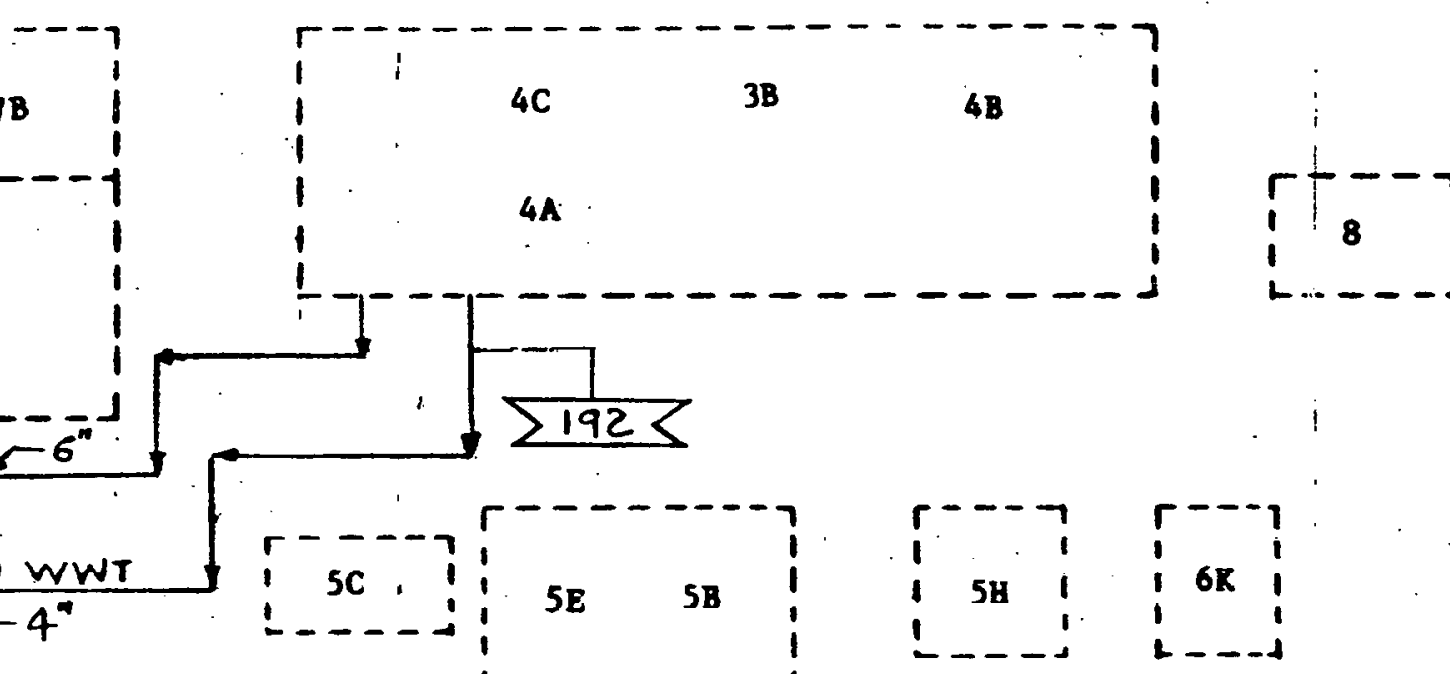

1....
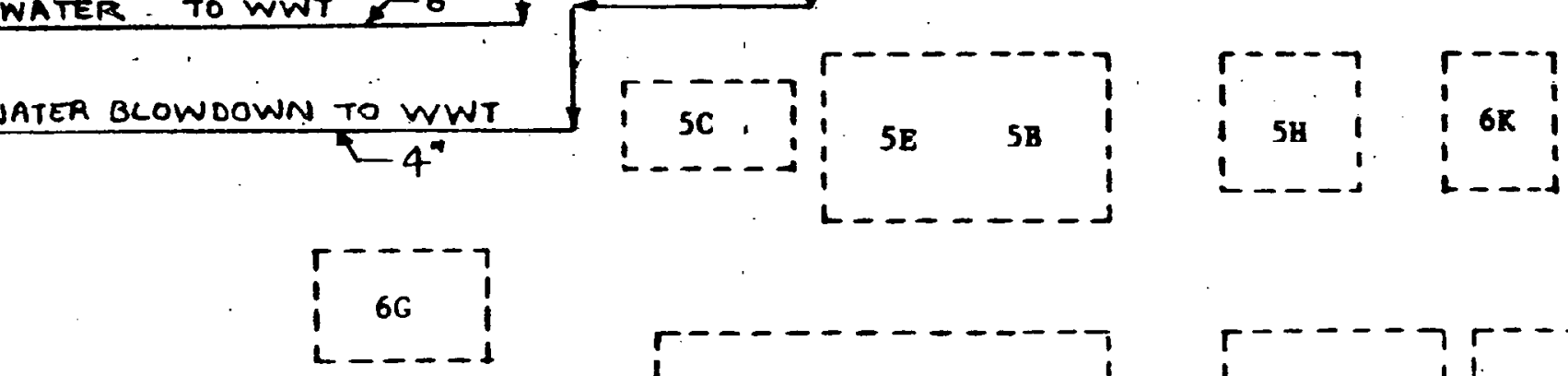

5A
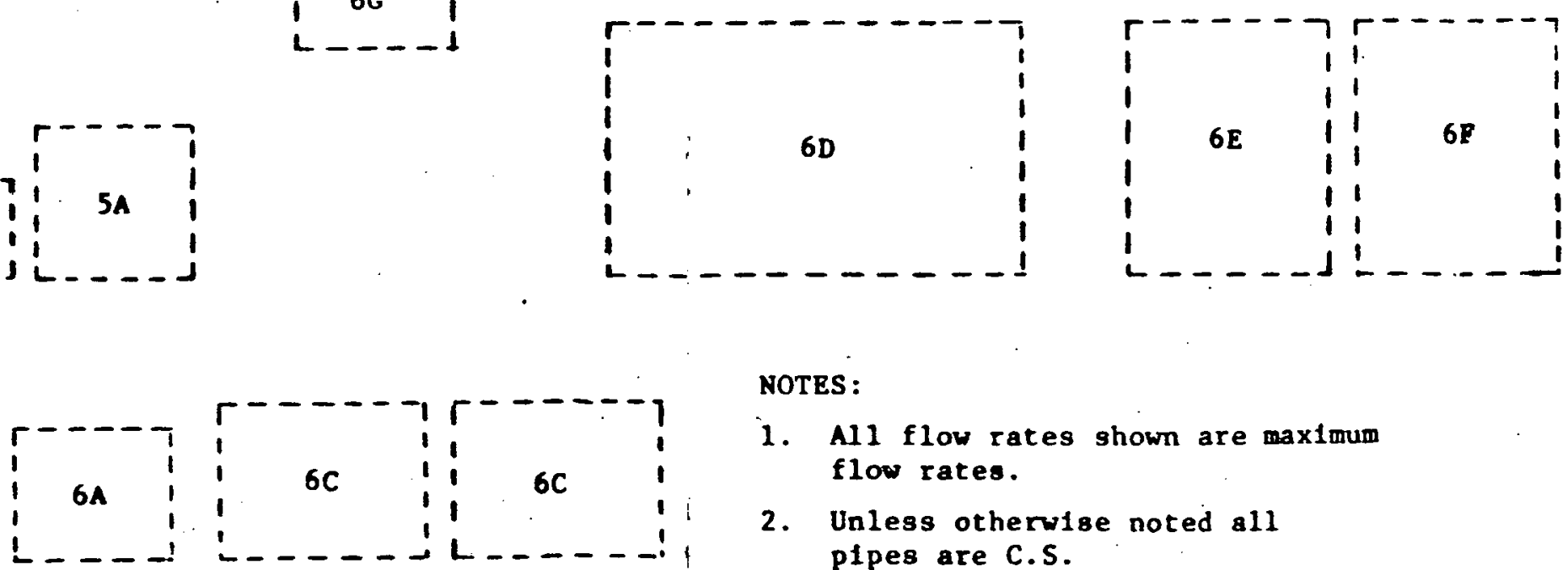

NOTES :

All flow rates shown are maximum flow rates.

2. Unless otherwlse noted all pipes are C.S.
AREA 12 SRC

IA SRC Process

1B Deashing

C Product Fractionation

Solidification

AREA 13 PRODUCT UPGRATINC 2A Coker/Calciner

2B Expanded-bed Hydrocracier

3 AREA 14 CRYOGENIC SEPARATION

3B Hydrogen Purification

4 AREA 15 GAS SYSTEMS

4 Gasilfation

4C Gulfur Recovery

5 AREA 16 UTILITIES

SB BFW Treatment

SC Cooling Tower No. 1

SE Power House and AIr Compressor

SF Flare

$5 G$ Liquid Thermal oxidizer

5H Gas Incinerator

6 AREA 17 OFFSITES

6 A Water Treatment

6B Wastewater Trea

6C Surge Basin

Land $\leqslant i 11$

促

6F Landfill Cover Stoci Pile

6 G Evaporator

6H Central Control Builiting

6I Administration Building

6J Service Change Building

6K Contract Maintenance Change B1dg.

6L Warehouse Building

6M Maintenance Buildin

6N Storm Retention Pond

60 Ash Ponds

7 AREA 11 RAW MATERIAL \& PRODLCT STORAGE

7 A Coal Storage

7B Coal Pulverizer

7 LRC Liqu Storage

8 NAPTHA HYDROTREATER 
RUST, BIRMINOHAM, ALAEA A

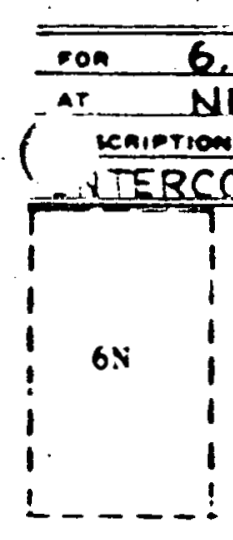

SRC-T DEMONST $\overline{R A T I O H}$

\section{$=-m$}

$21-2548$

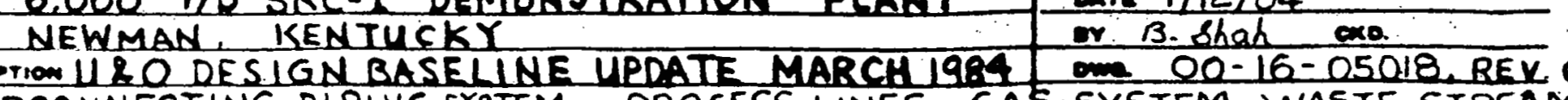

TECONECTING PIPING SYSTEM - PROCESS LINES - GAS.SYSTEM WASTE STREAMS

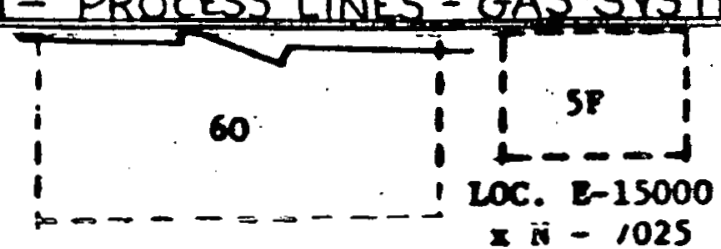

$7 c$
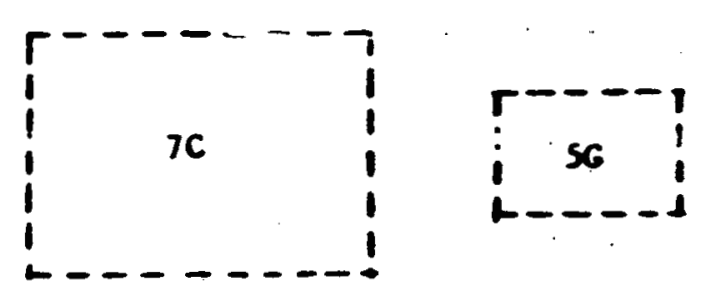

70

74
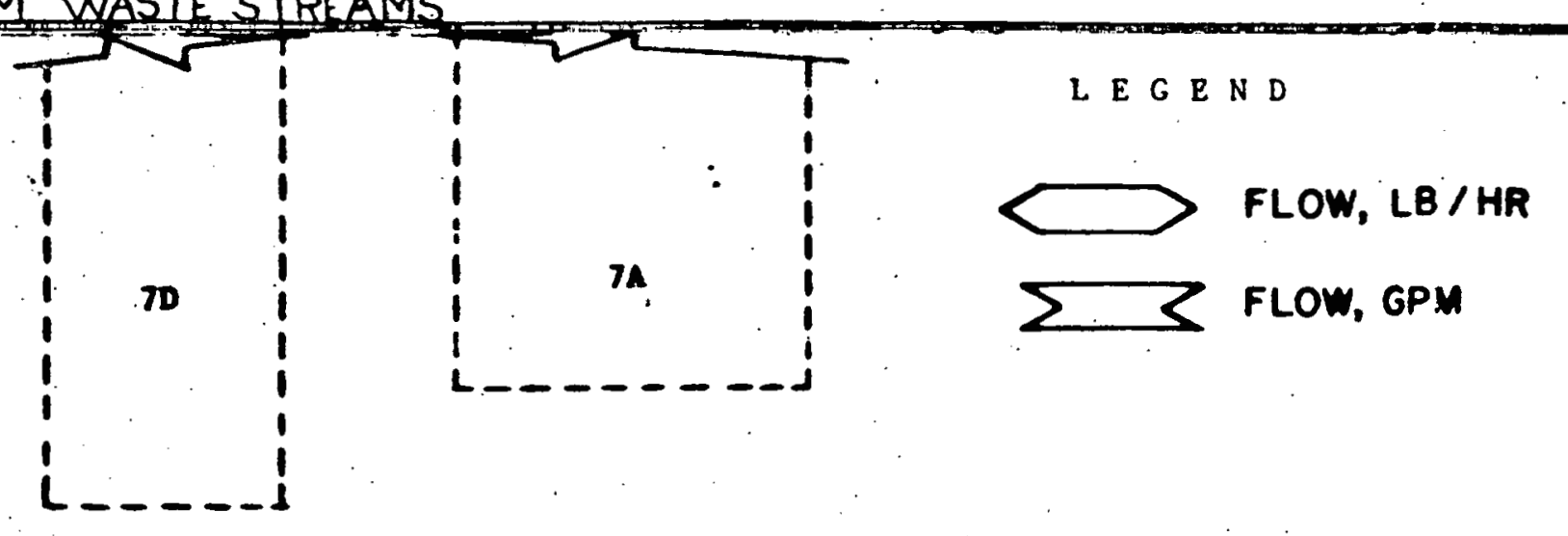

AREA 12 SRC

IA SRC Process

18 Deashing

IC Product Fractionart

1D Solidification

2 AREA 13 PRODUCT UPGRADING

2B Expanded-bed Hydrocracker

3 AREA 14 CRYOCENIC SEPARAIION 3A Air Separation 3B Hydrogen Purlfication

4 AREA 15 GAS SYSTEYS

4A Gasification

4C Sulfur Recovery

6I
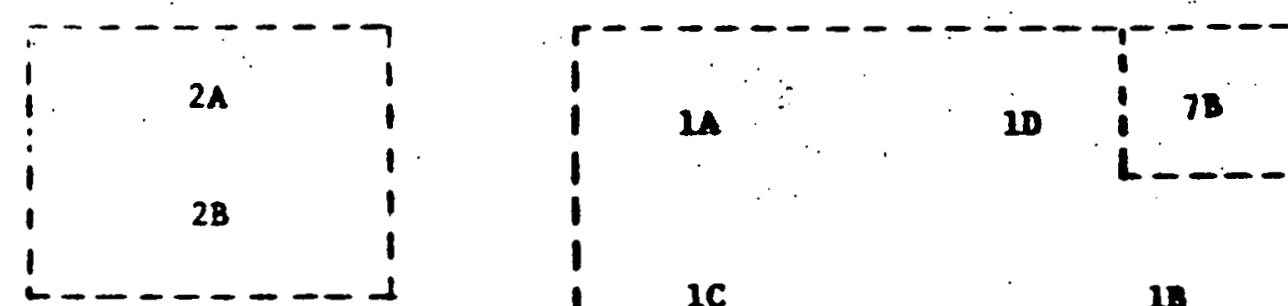

IC

18

$4 c$

38

4B $\begin{array}{r}\text { i } \\ \text { i }\end{array}$

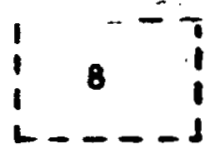

5A Main Substation

SB : BFW Treatment

SC Cooling Tower No. 1

5D Cooling Tower No. 2

SF. Power Howes and Atr on

SG Fare

5H Gas Incthermal Oxidizer

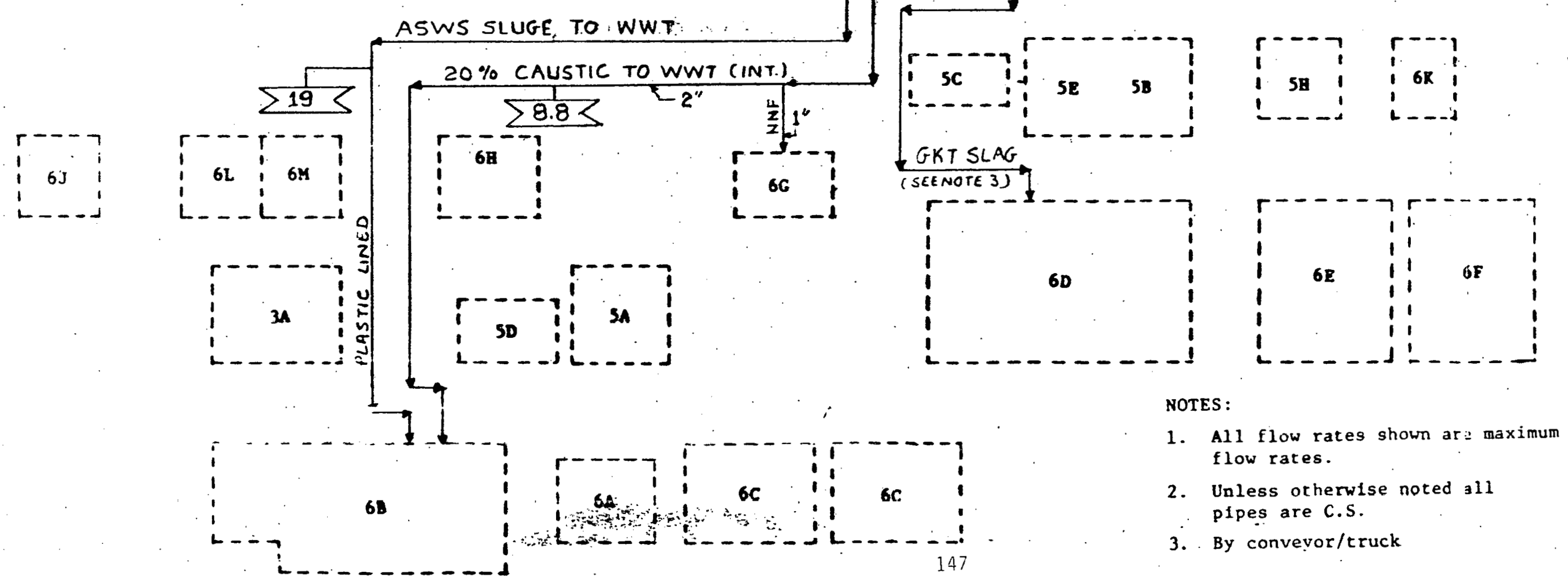

6 AREA 17 OFFSITES

6B Wastewater Treatmen:

6C Surge Basin

6D Mazardous Waste Land $i$ ill

6F Landfill Cover Stock. Pile

6H Central Control Building

6I Adulnistracion Bullding

6K

Change Bldg.

6M Maintenance Building

6N Storm Retention Pond

60 Ash Ponds

AREA 11 raw material o PRODLC? STORAGE

7A Coal Storage

it coai Fuiverizer

$7 C$ Liquid Storage
$7 D$ SRC/ISL Storage

8 NAPHTHA HYDROTREATER
6 E Non-Hazardous Waste Landfill 
MUST, DIREINOHAR, ALABABEA ron 6,000 T/O SRC-I DEMONSTBATION PLANT

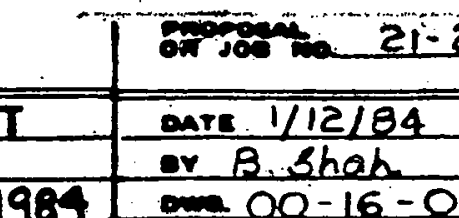
IERCONNECTING PIPING STSTEM - PROCESS LINES - NAPHTHA HYDROTREATING

60 1. $x$ ix -7025

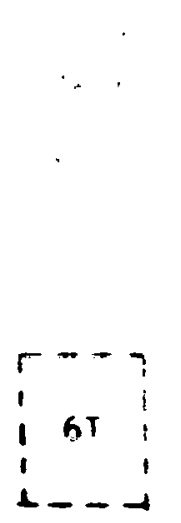<smiles>CC[IH]CC</smiles>

$\left[\begin{array}{c}---7 \\ 6 \mathrm{~J} \\ -\ldots\end{array}\right.$

\section{$r$}

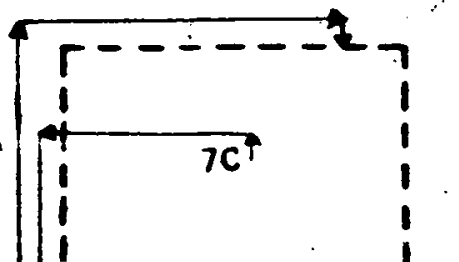

sc

ic
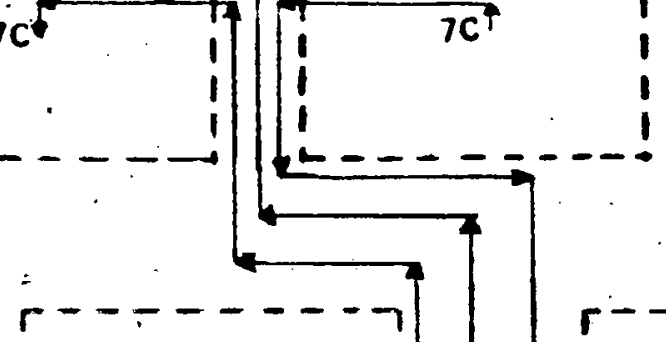

$i^{--}$

2B

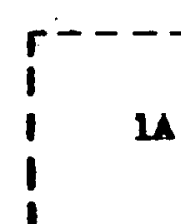

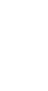
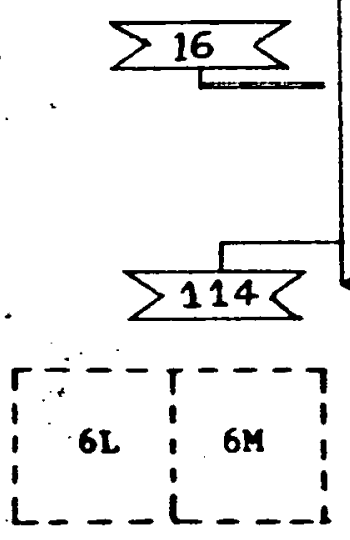

PROD

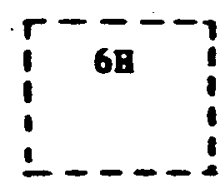

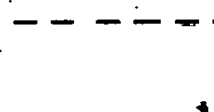

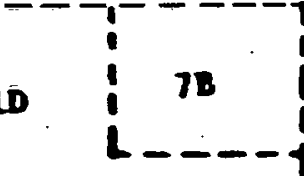

DUCT NAPHTHA TO STORAGE
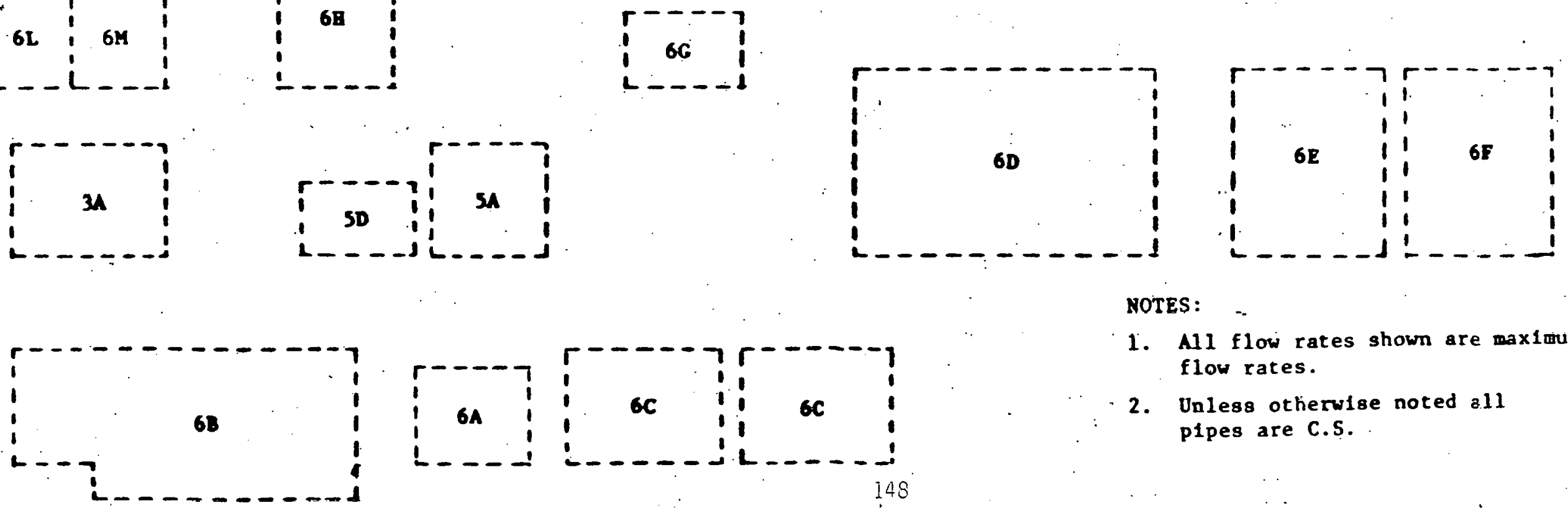

NOTES:

1. All flow rates shown are maxiarum flow rates.

2. Unless otherwise noted all p1pes are C.S
1 AREA 12 SRC

IA SRC Proce

18 Deash1ng

IC Product Fractionation

ID Solldification

2 AREA 13 PRODUCT UPGRADING $2 A$ Coker/Calc1ner

2.B Expanded-bed Hydrocracker

3 AREA 14 CRYOCENIC SEPARATION

3A Air Separation

3B Hydrogen Purification

4 AREA 15 GAS SYSTEMS

4A Gas1fication

tC sulfur Recovery

5 AREA 16 UTILITIES

5A Main Substacton

5B. BFW Treatment

SC.Cooling Tower

5D Cooling Tower to.

5F. Power Pnise and Air rompressor

SF Flare

SG Liquid Thermal oxidizer

5H Gas Inçinerator

6 AREA 17 OFFSITES

6A Water Treatment

6B Wastewater Treatien

6C Surge Basin

6E Won-Haraidous Wand ${ }^{2} i$

6F Lanfili Cover Stock Palle

6C Evaporator

6H Cencral Con

6I Adetatatrentrol Building

6J Service ration Bullding

6K Contract Maintenance Change Bldg.

6L Warehouse Bullding

6N Storw Retention Pond

60 Ash Ponds

7 area 11 raw material 8 product STORAGE

7 Coal Storage

7B Coal Pulverizer

7 Liquid Storage

8 NAPHTHA HYDROTREATER 


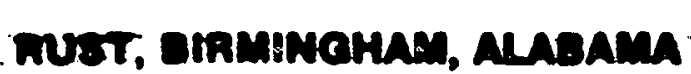

$20001-2548$ . 200 T/O SRC-I DEMONSTRATION PLANT DATE 1/24/84

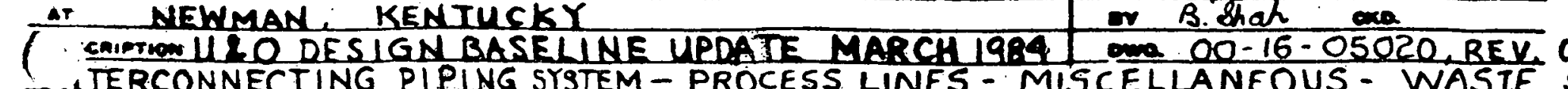
IERCONNECTING PIPING SYSTEM - PROCESS LINES - MISCELLANEQUS - WASTE STREAMS

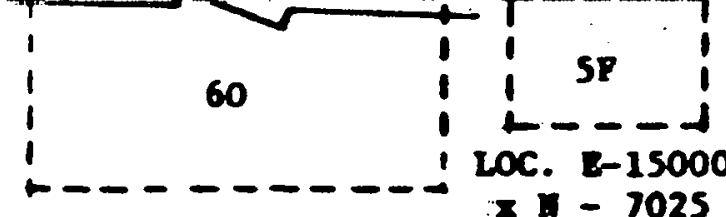

LOC. $8-15000$

1.
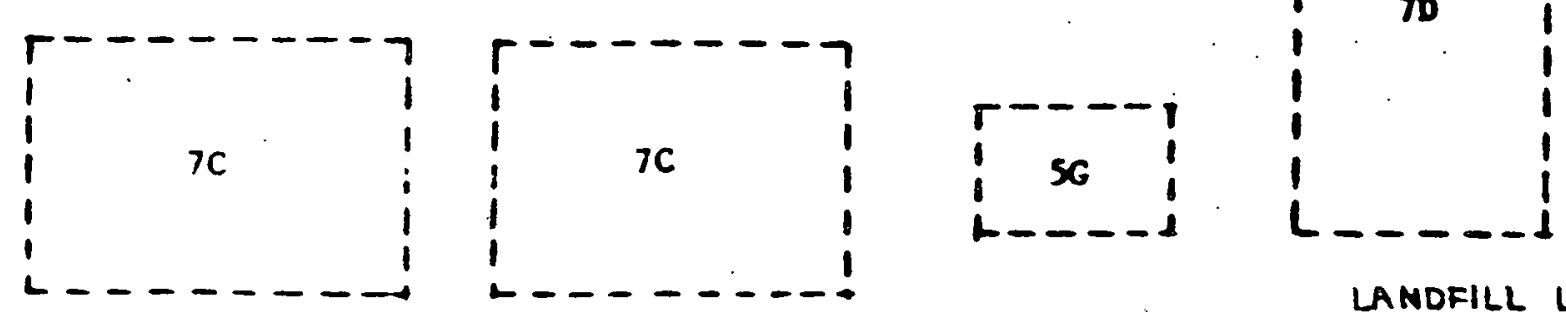

LANDFILL LEACHATE

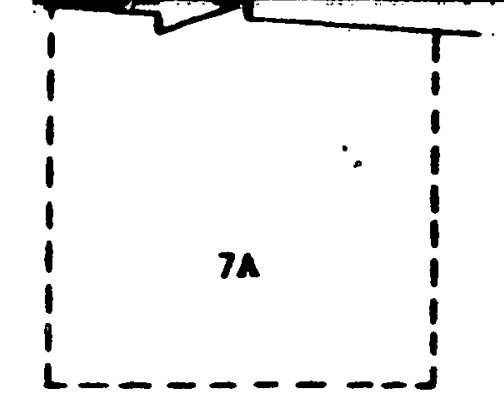

LEGEND

$\longrightarrow$ FLOW, LB/HR

FLOW, GPM

$5^{--}$
61
1

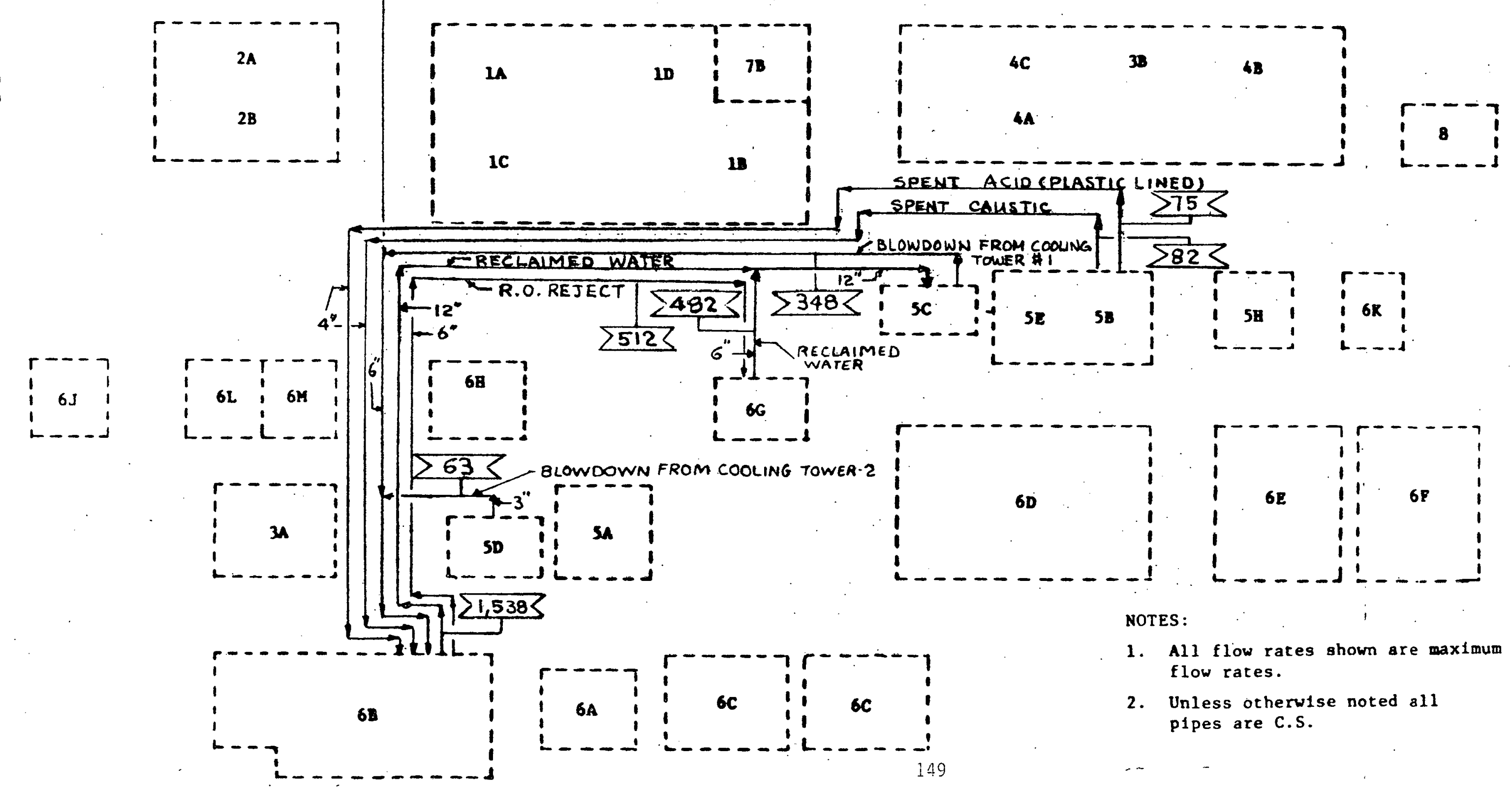

1 AREA 12 SRC

2A SRC Process

18 Deashing

ID Solidification

2 AREA 13 PRODUCT UPGRADINC

Axpanded-bed Hydrocracker

3 AREA 14 CRYOGENIC SEPARAIION

rification

4 AREA 15 GAS SYSTEYS

4A Gasification

4C Sulfur Recovery

\section{AREA 16 UTILITIES}

SB Main Substation

SC Cooling Tower No. 1

5D Cooling Tower No. 2

SE Power House and AIr Compressor

SF. Flare

56 Liquid Thermal Oxidizer

5H Gas Incinerator

6 AREA 17 OFFSITES

6 A Water Treatment

6B Wastewater Treatment

6C Surge Basin

6D Hazardous Waste Land $i$ il

6E Non-Hazardous Waste Landfill

6F Landfill Cover Stock Pile

Central Control Bullding

61 Administration Bullding

6r Service Change Butlding

6x Contract Maintenance

6M Warehouse Bullding

6N Storm Retention Pond

60 Ash Ponds

7 AREA 11 RAW MATERIAL \& PRODUCT

7A Coal Storage

7 B Coal Pulverize

$7 C$ Liquid Storage

7D SRC/TSL Storage

8 NAPHTHA HYDROTREATE? 


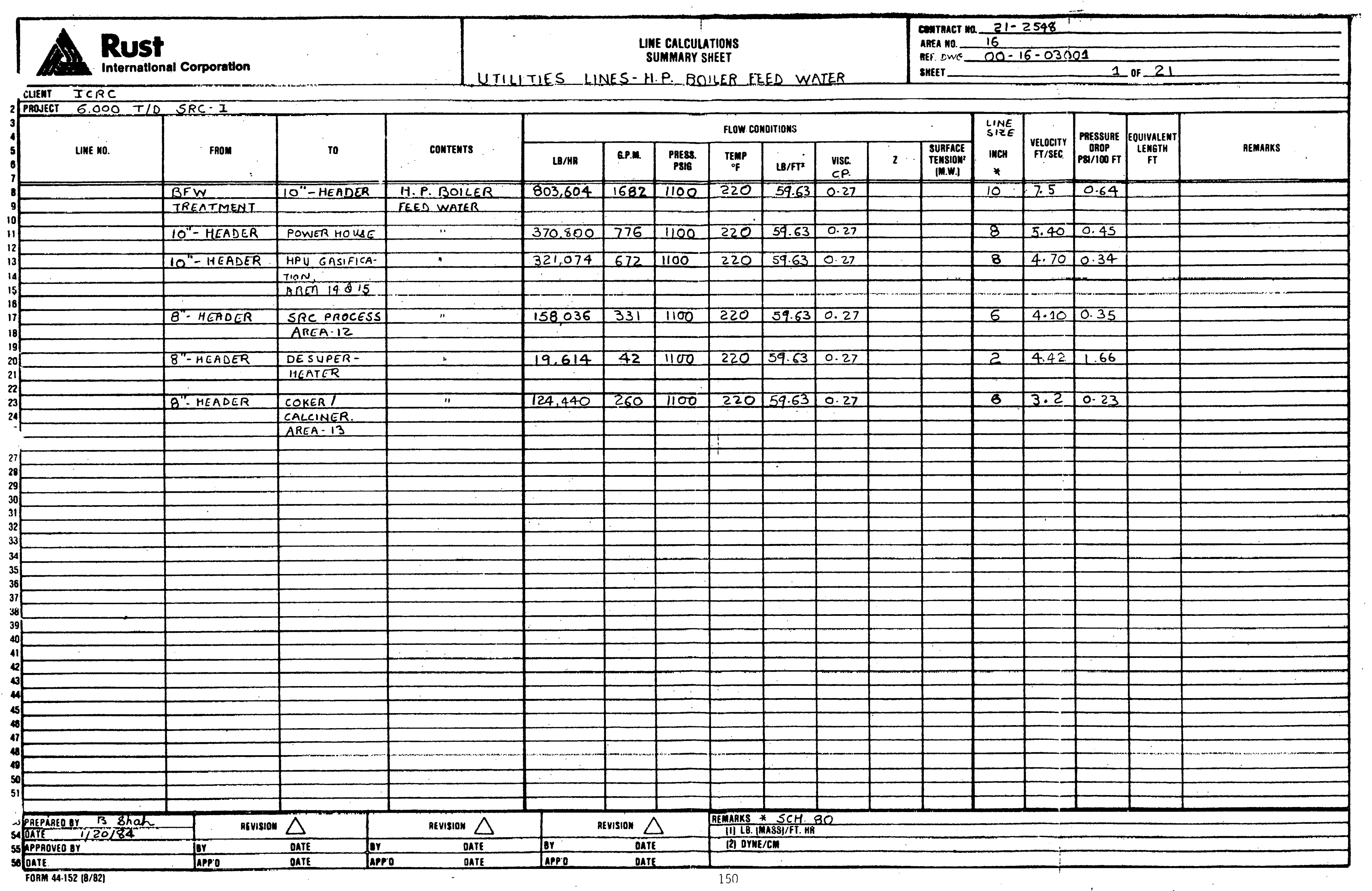




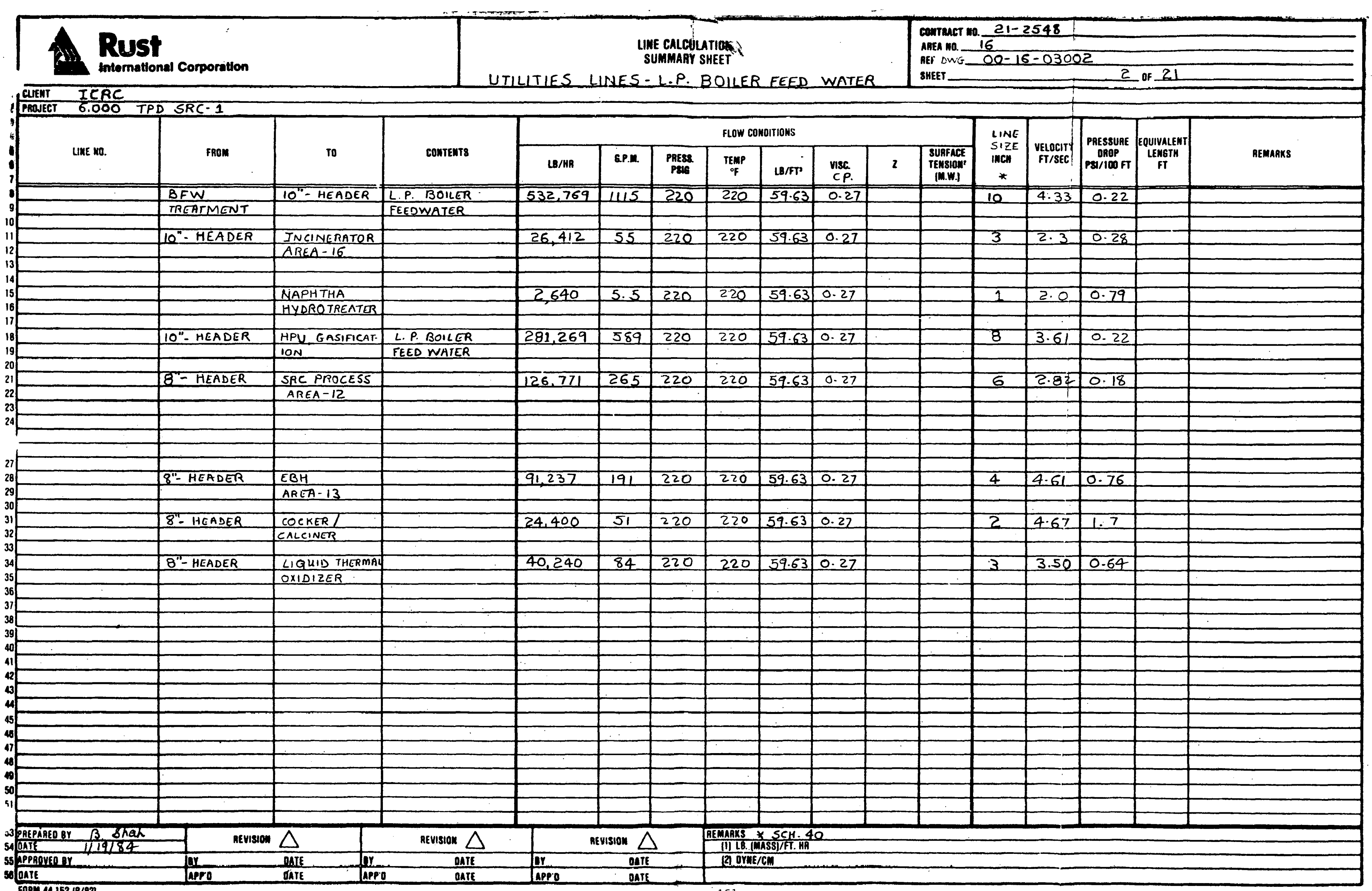




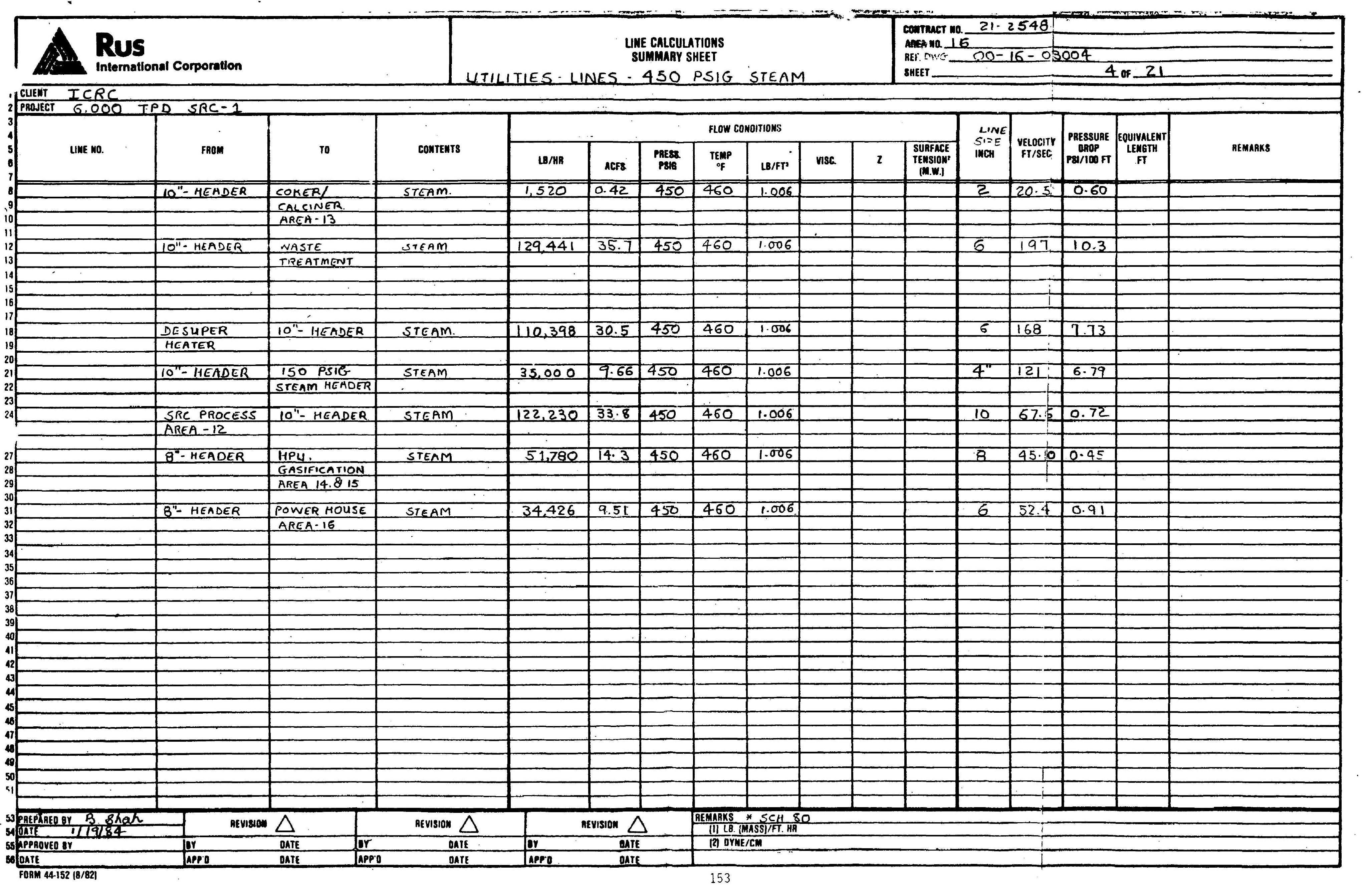




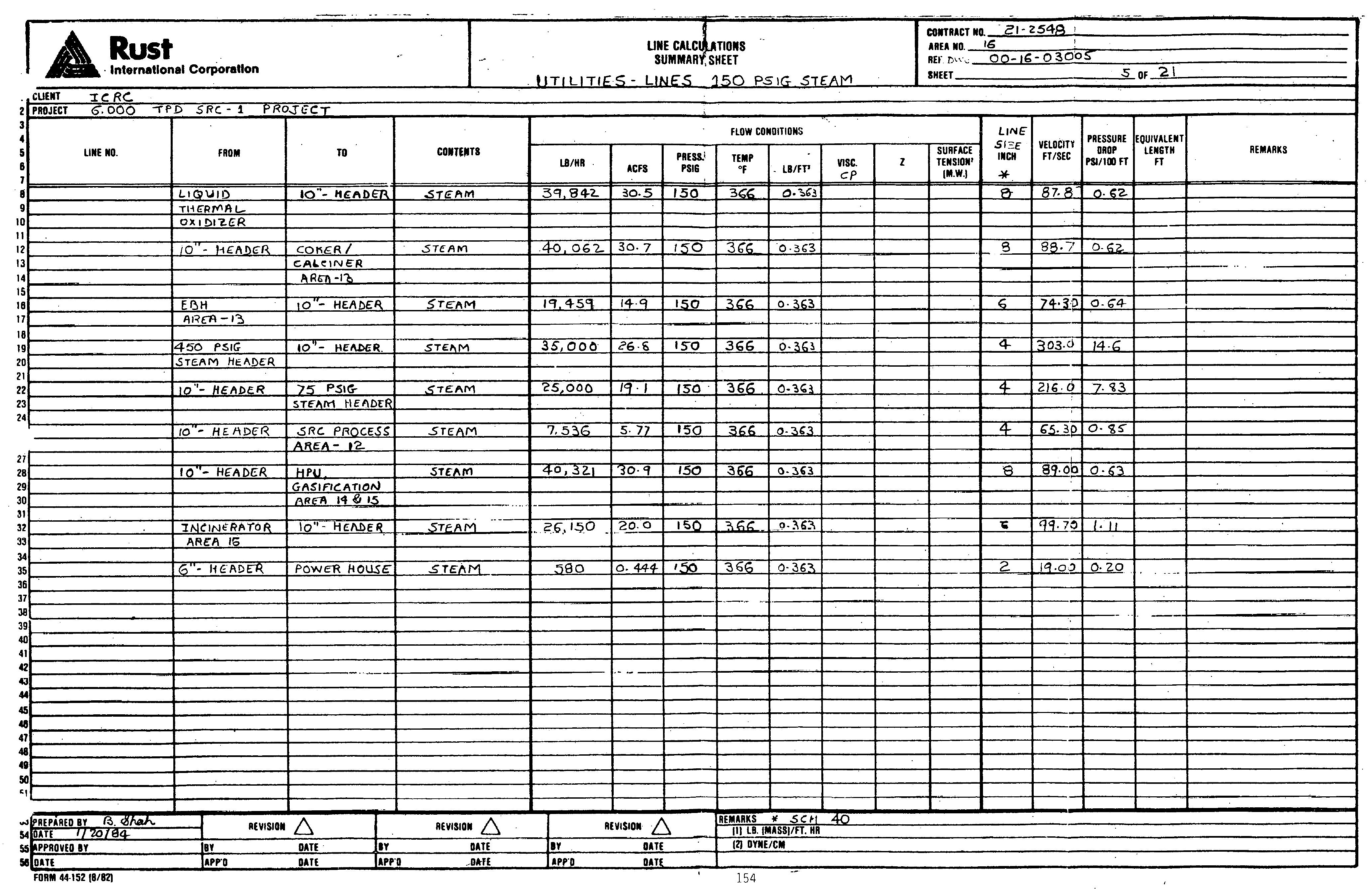




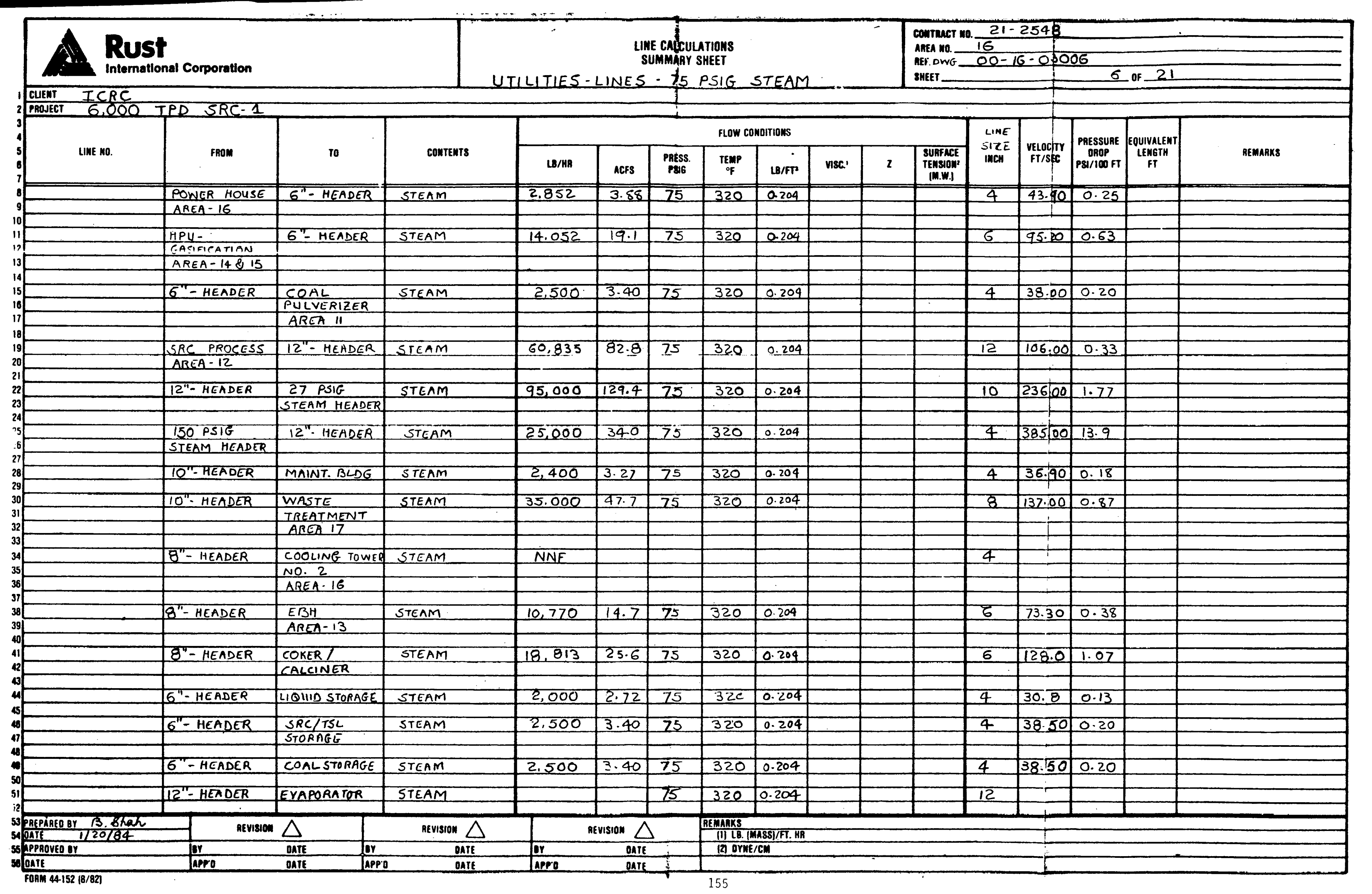




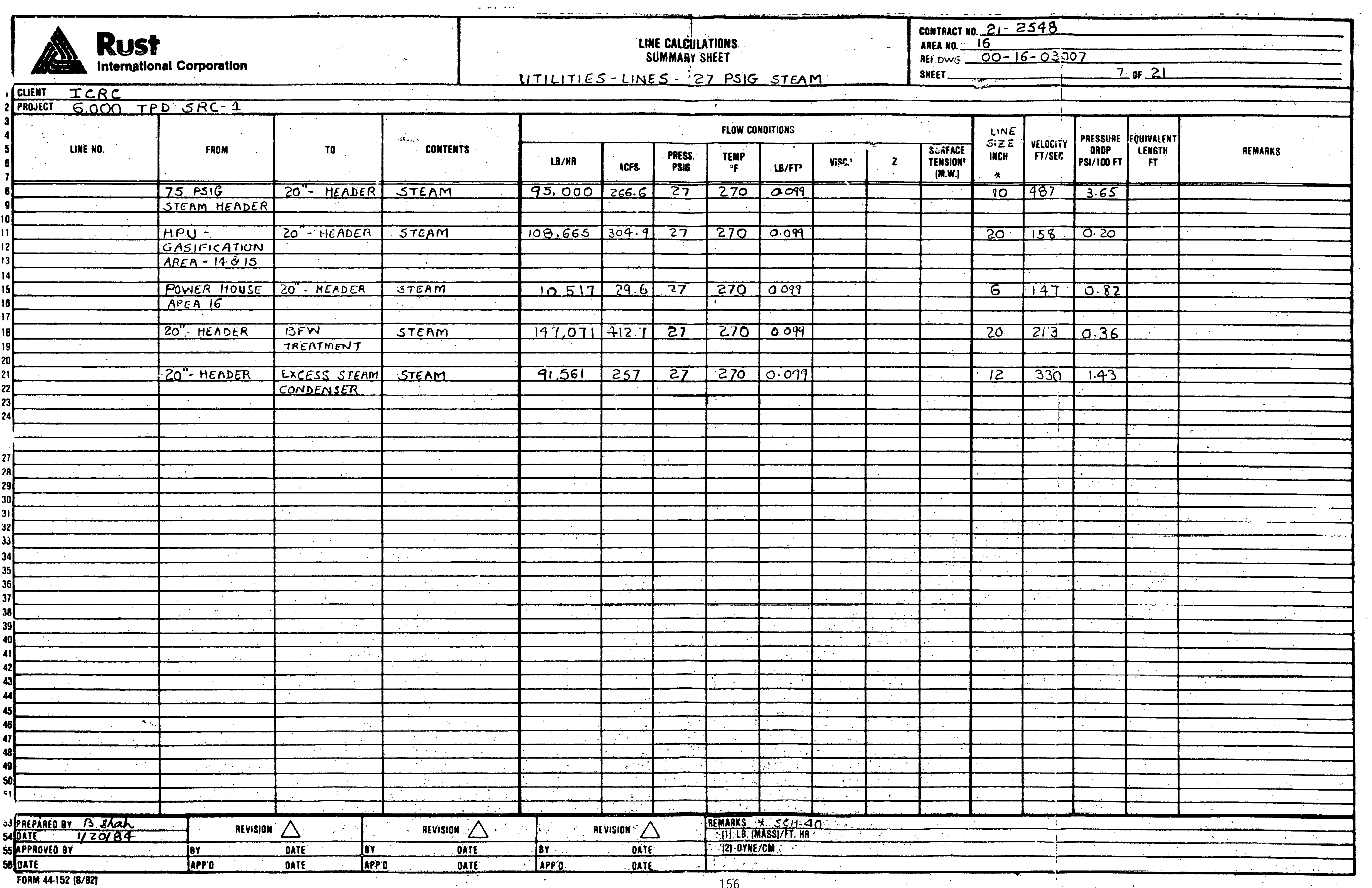




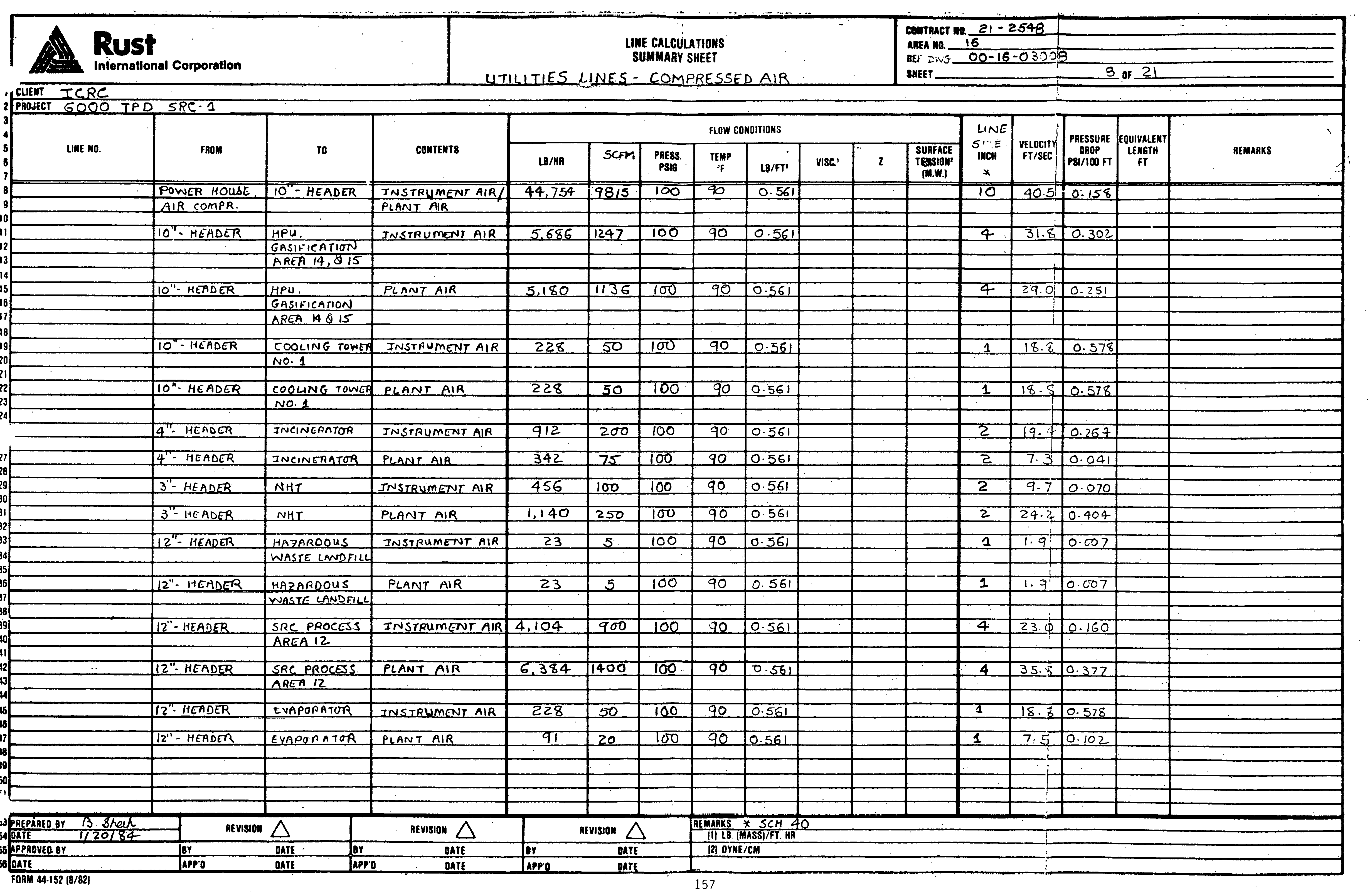




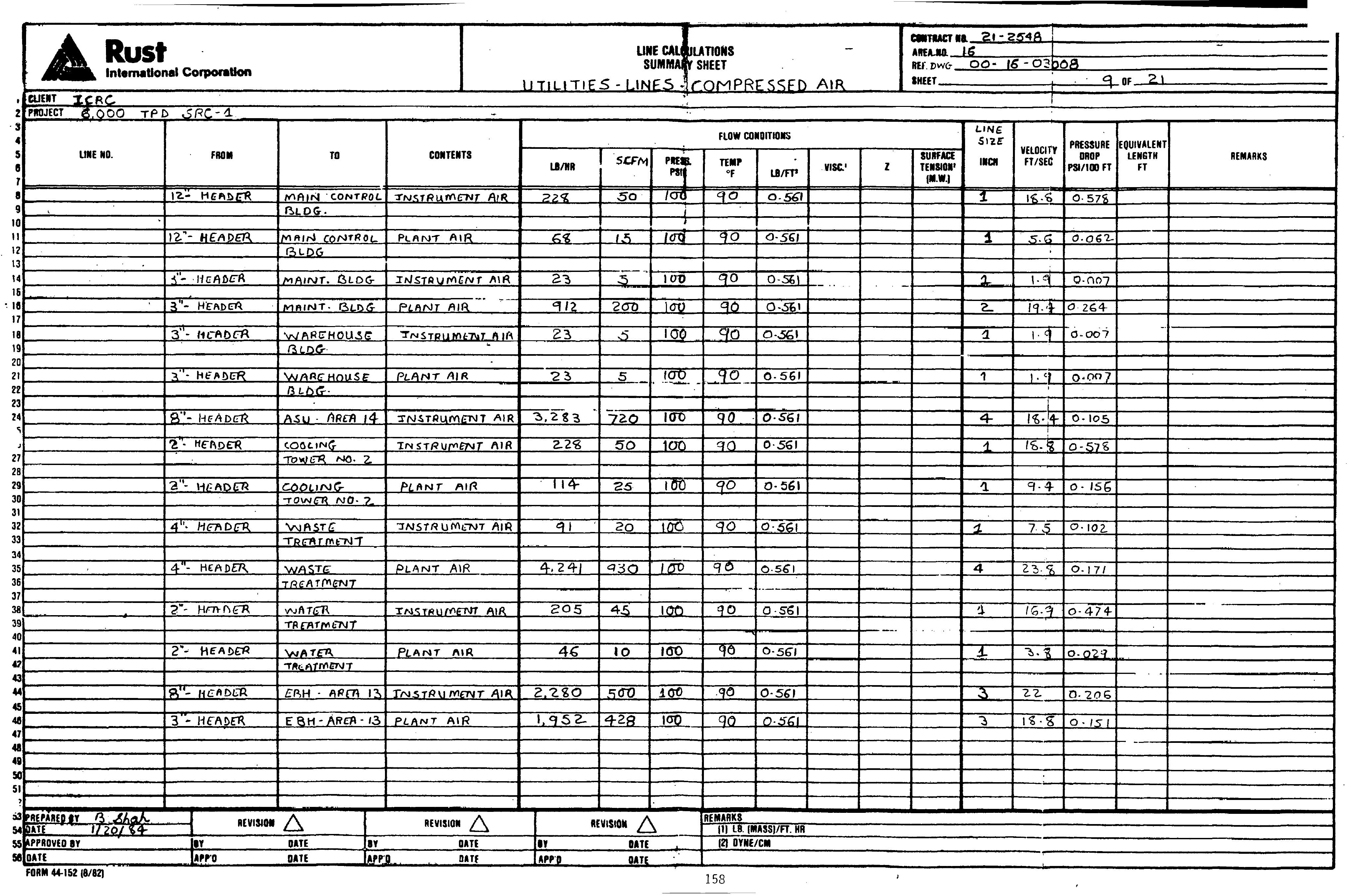


Rust

CUENT TCRC

PRQJECT 6.000 TPD $S R C-1$

\begin{tabular}{|c|c|c|c|c|c|c|c|c|c|c|c|c|c|c|c|c|}
\hline \multirow[b]{2}{*}{ LIME NO. } & \multirow[b]{2}{*}{ FROM. } & \multirow[b]{2}{*}{ To } & \multirow[b]{2}{*}{ CONTENTS } & \multicolumn{8}{|c|}{ Flow CONOITrons } & \multirow{2}{*}{$\begin{array}{l}\text { LNE } \\
\text { SIZE } \\
\text { IRCW }\end{array}$} & \multirow{2}{*}{$\begin{array}{l}\text { VEElocity } \\
\text { FT/SEC }\end{array}$} & \multirow{2}{*}{ 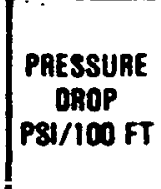 } & \multirow{2}{*}{$\mid \begin{array}{c}\text { EoUIYALENT } \\
\text { LENGTH } \\
\mathrm{FT}\end{array}$} & \multirow[b]{2}{*}{ REMARKS } \\
\hline & & & & Le/RB & SCFM & $\begin{array}{c}\text { Ppegar } \\
\text { Pass }\end{array}$ & Trmp & 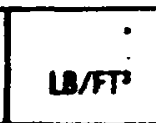 & Visc: & 2 & 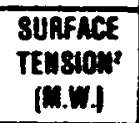 & & & & & \\
\hline 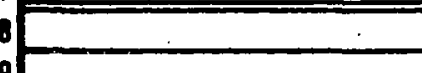 & AsU & $12^{n-}$ - MEADER & NITROGEN & 116927 & 26.400 & 80 & 77 & 0.461 & & & & 12 & 90.6 & & & \\
\hline & ARCA - 14 & & & & & & & & & & & & & & & \\
\hline if & $8^{\prime \prime-H E A D E R}$ & $E B H$ & NITROGEN & 2,976 & 672 & 80 & 77 & 0.461 & & & & $\frac{4}{4}$ & 20.3 & & & \\
\hline & & AREA 13 & & & & & & & & & & & & & & \\
\hline & 8"- HEADER & COKFBI & NITROGEN & 961 & 217 & 80 & 77 & 0.461 & & & & 2 & 24.9 & & & \\
\hline & & CALCINER & & & & & & & & & & & & & & \\
\hline 7) & $8^{\prime \prime}$ - HEADER & LIQUID STORAGE & NITROGEN & 6,865 & 1550 & 80 & 77 & 0.461 & & & & 4 & 46.8 & & & \\
\hline 9! & 8"- HEADER & COAL STORAGE & NITROGEN & 2,879 & 650 & 80 & 77 & 0.461 & & & & 4 & $19 \cdot 6$ & & & \\
\hline & & AREA II & & & & & & & & & & & & & & \\
\hline 2) & $12^{11}$ - HEADER & SRC PROCESS & NITROGEN & 40,384 & 9118 & 80 & 77 & 0.461 & & & & 10 & 44.5 & & & \\
\hline & & AREA 12 & & & & & & & & & & & & & & \\
\hline & $12^{n}$ - HEADER & HPY. & NITROGEN & 115,257 & 26,023 & 80 & 77 & 0.461 & & & & 12 & 89.3 & & & \\
\hline & & GASIFICATION & & & & & & & & & & & & & & \\
\hline 8 & 12: HEADER & $\mathrm{NHT}$ & NITROGEN & 443 & 100 & 80 & 77 & 0.461 & & & & 2 & 11.5 & & - & \\
\hline & & & & & & & & & & & & & & & & \\
\hline & & & & & & & & & & & & - & & - & E & \\
\hline & & & & & & & & & & & & & & & & \\
\hline & & & & & & & & & & & & - & -1 & $E$ & 5 & \\
\hline & & & & & & & & & & & & E & 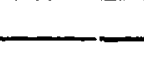 & & & \\
\hline & & & & & & & & & & & & & - & - & & \\
\hline & & & & & & & & & & & & - & 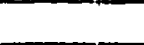 & 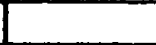 & 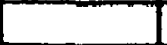 & \\
\hline & & & & & & & & & & - & - & - & - & 1 & - & \\
\hline & & & & & & & & & & & & - & & - & $E$ & \\
\hline & & & -1 & & & - & & & & & & & & & & \\
\hline & & & & & & & & & & & - & $\bar{L}$ & & & & \\
\hline & & & & & & & & & - & & & 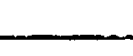 & & & & \\
\hline & & & & & & & & & & & & L & $\ldots$ & E & & \\
\hline & & & & & & & & & & & & & & & & \\
\hline & & & & & & & & & & & & - & & & & \\
\hline & & & & & & $\ldots$ & & & & & & & & & & \\
\hline 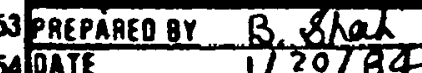 & REVISII & $\triangle$ & REvision $\triangle$ & & Evison $\triangle$ & & & 85ानह पू & & & & & & & & \\
\hline 55 PPPAOVEO OY & for & OAIE & oufE & fur & Dafe & & 210 or & & & & & & & & & \\
\hline$=5$ & LAPPO & OATE & oufe & APPPD & & & & & & & & & & & & \\
\hline
\end{tabular}




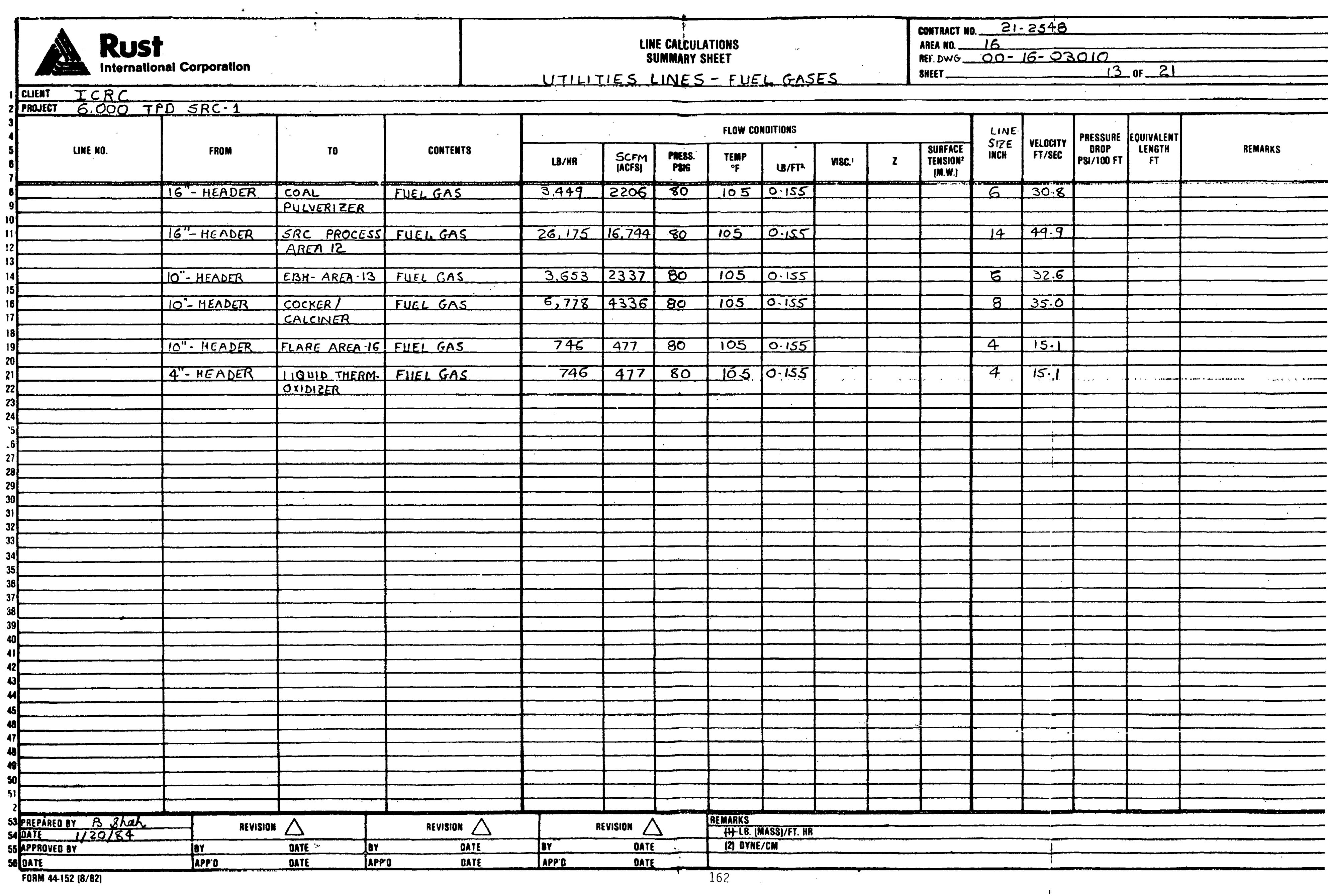




\section{Rust}

International Corporation

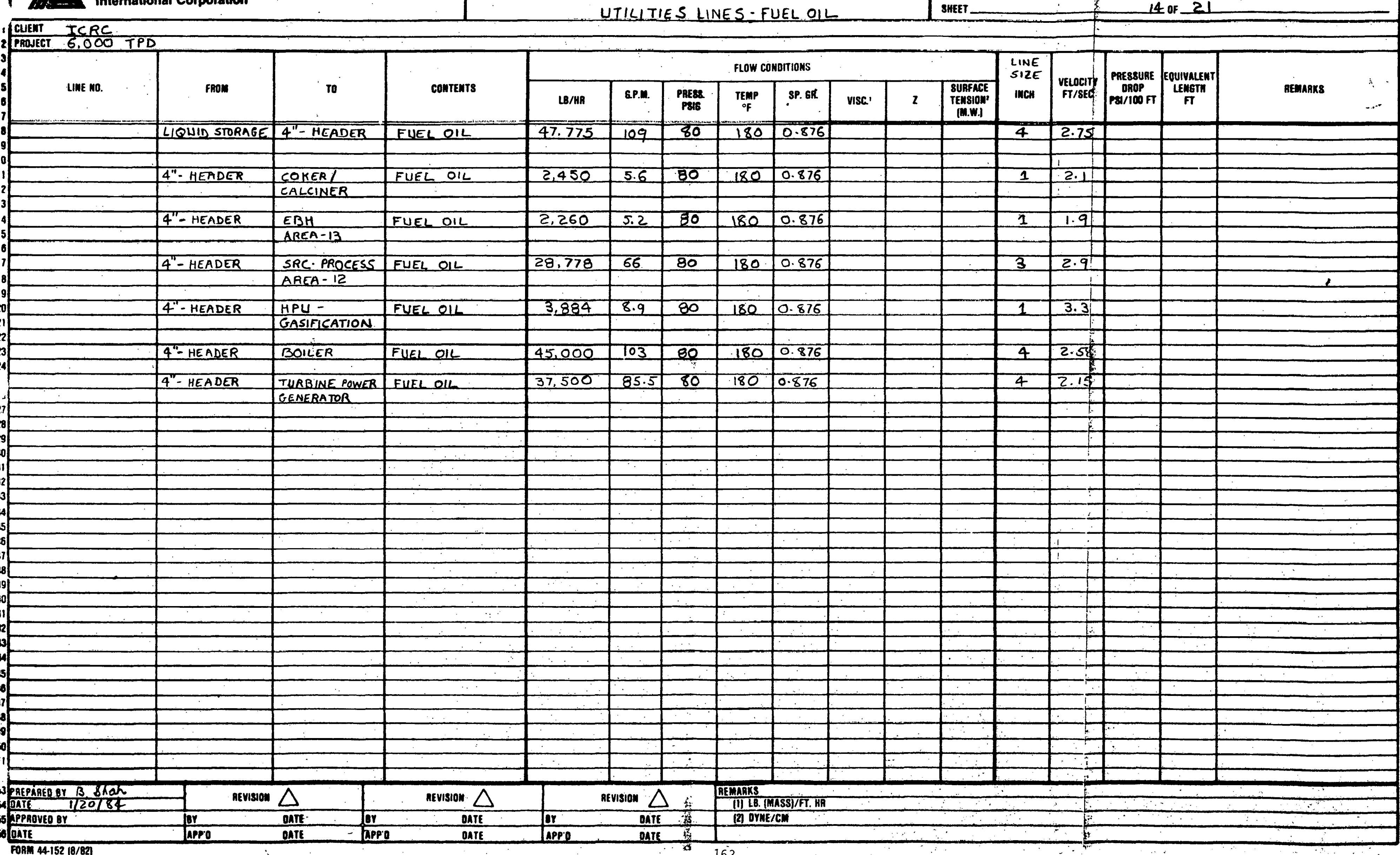


Af Rust

LIME CALCULATIONS

SUMMAAY SHEET

courraci wo. $21-2548$

AEF DWG $00-16-030.12$

CUIEAT ICRC

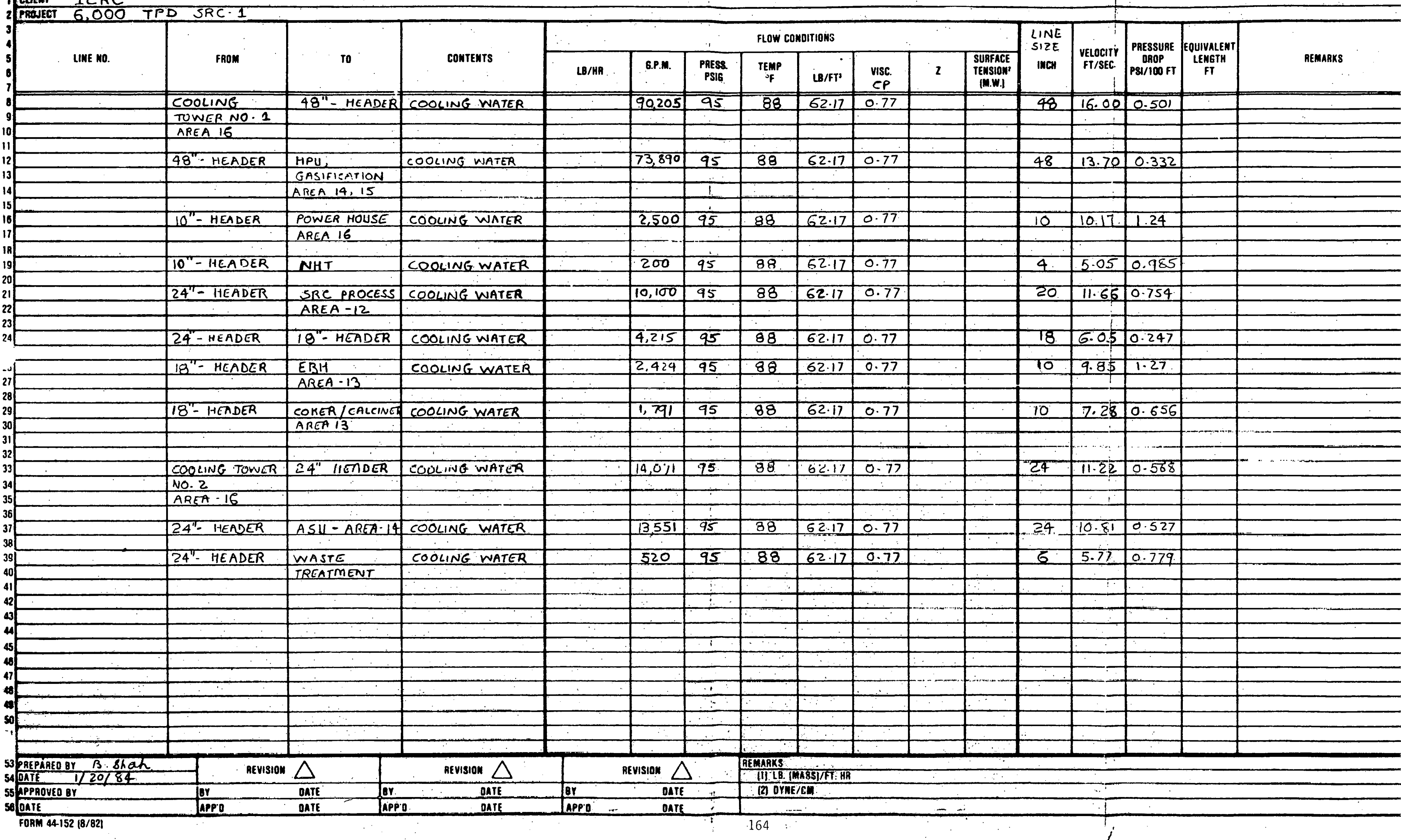




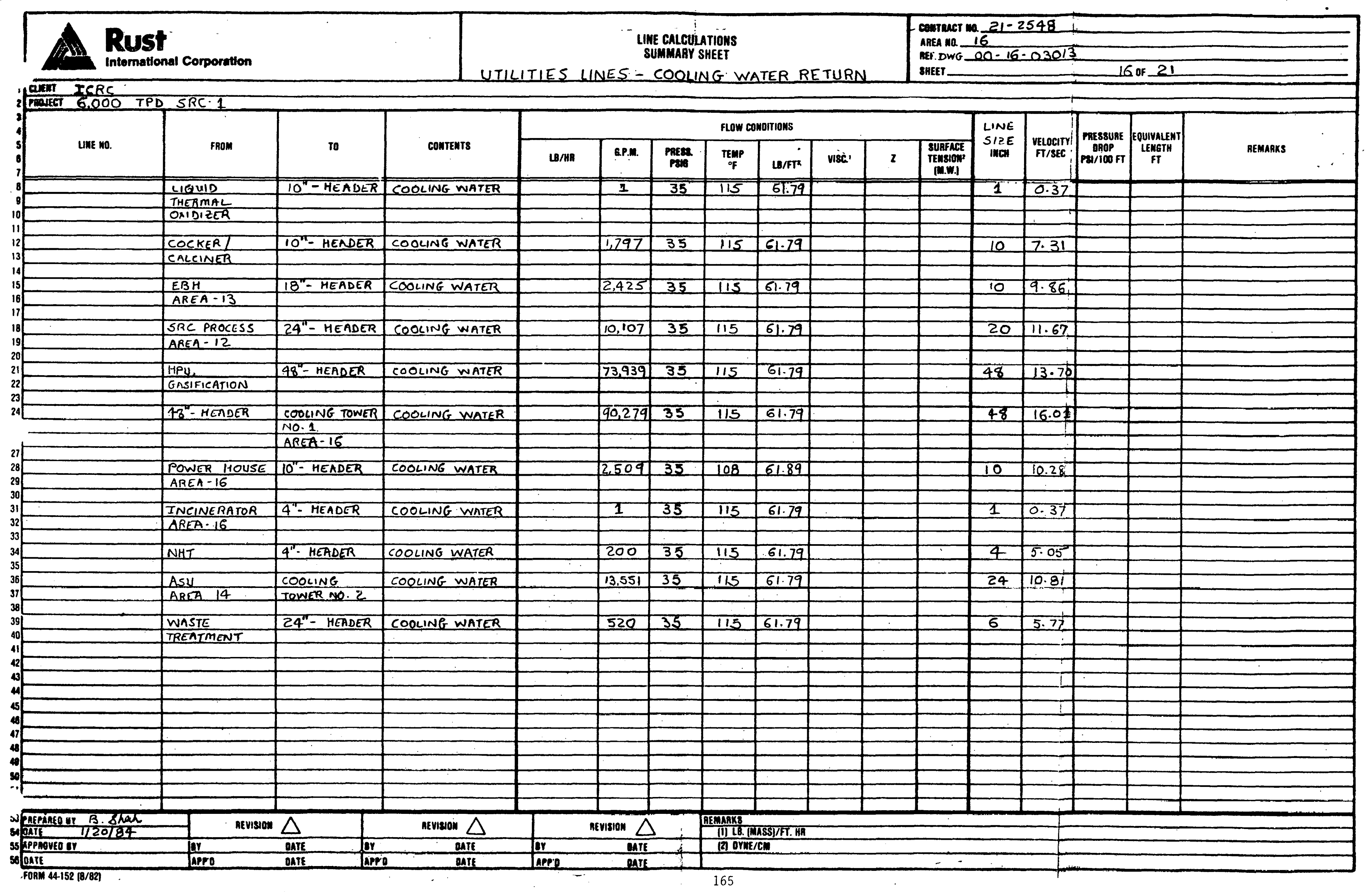




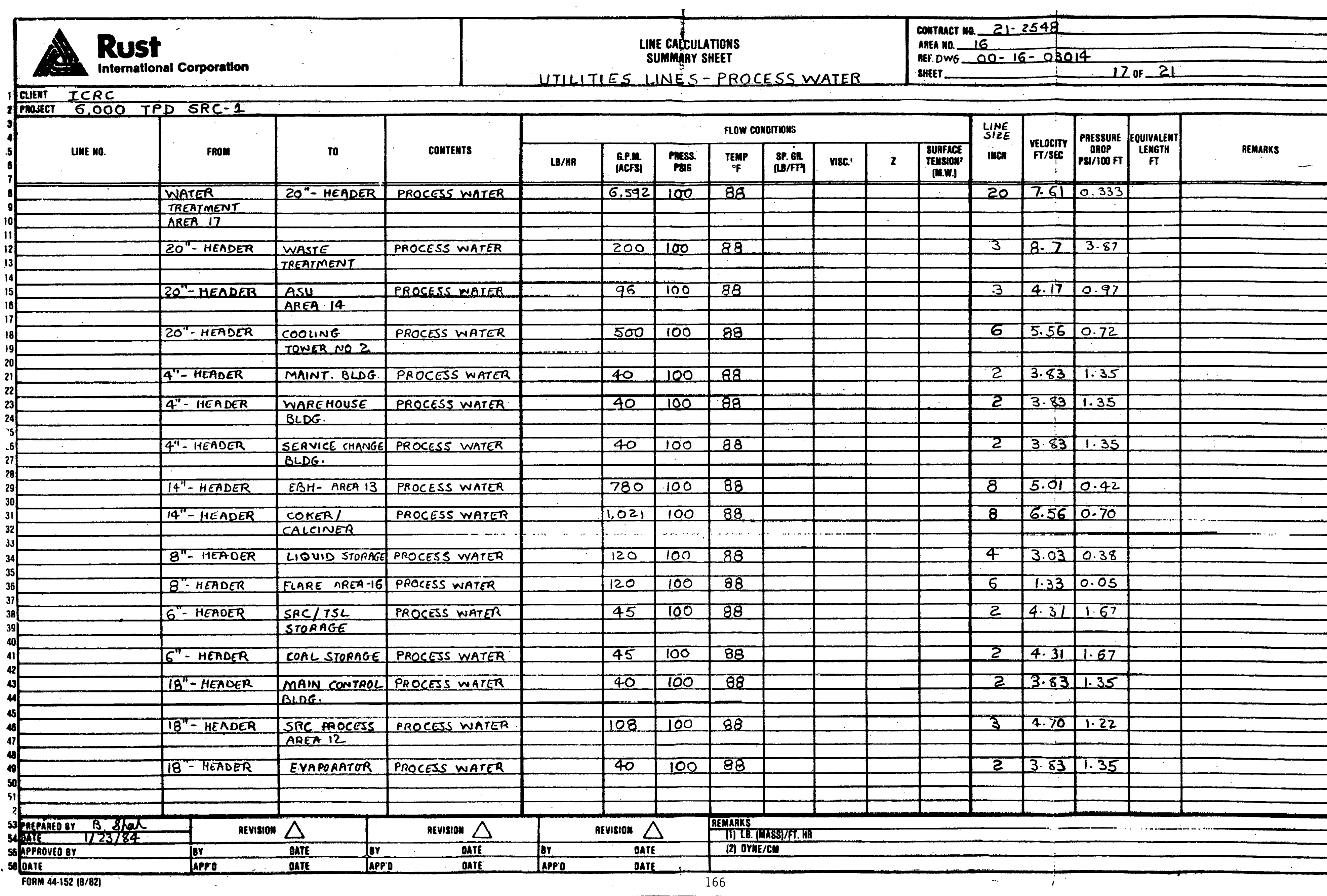




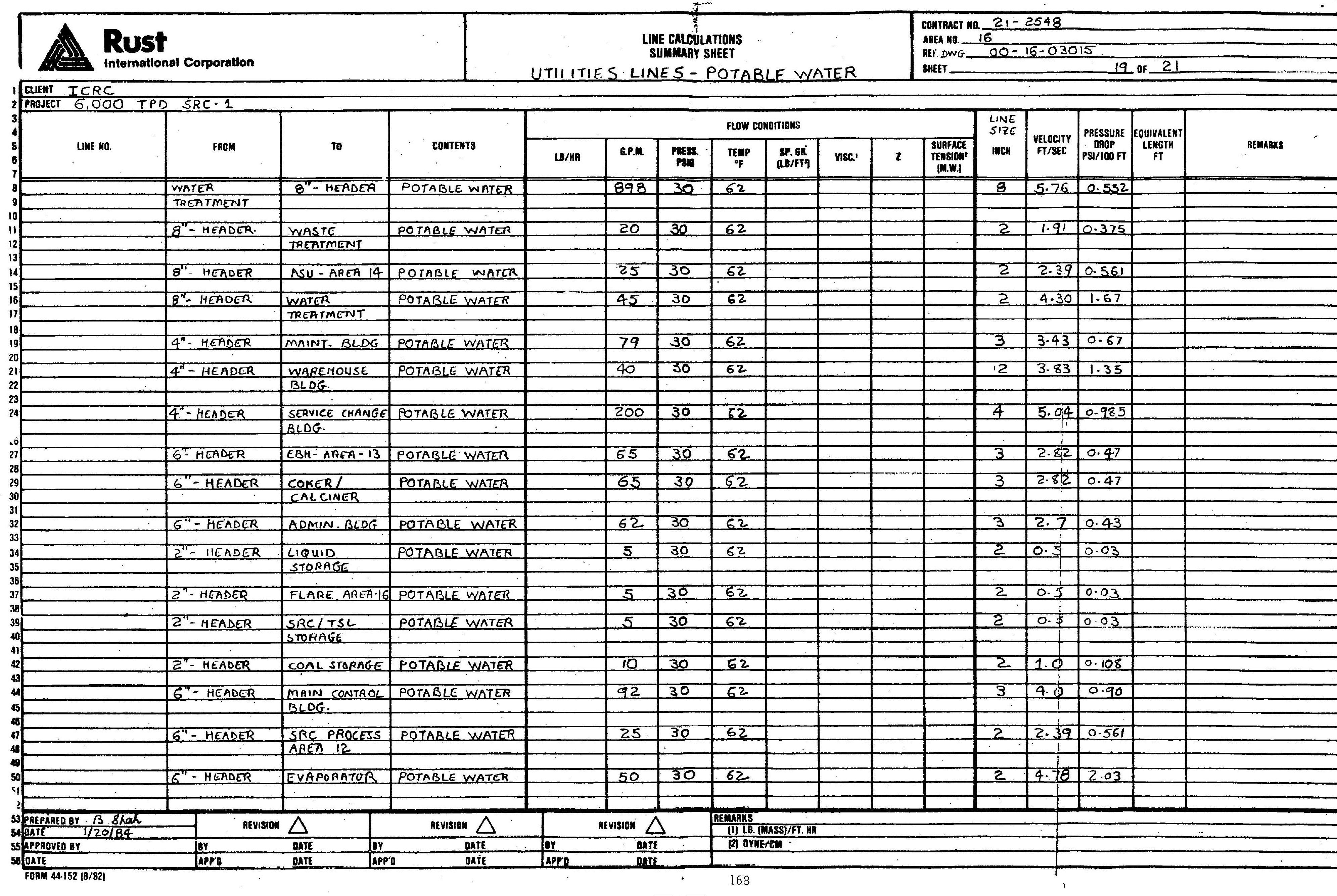




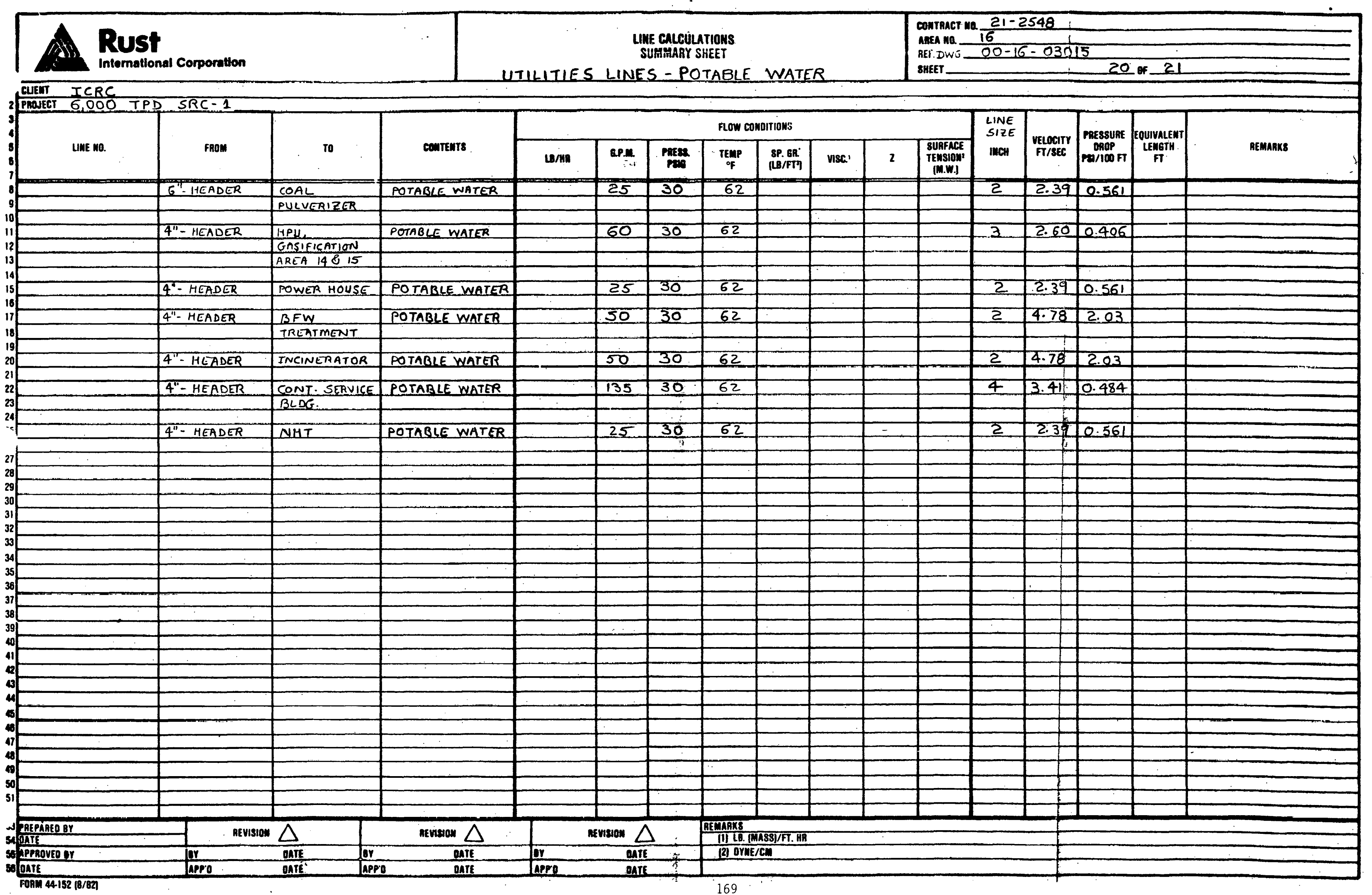

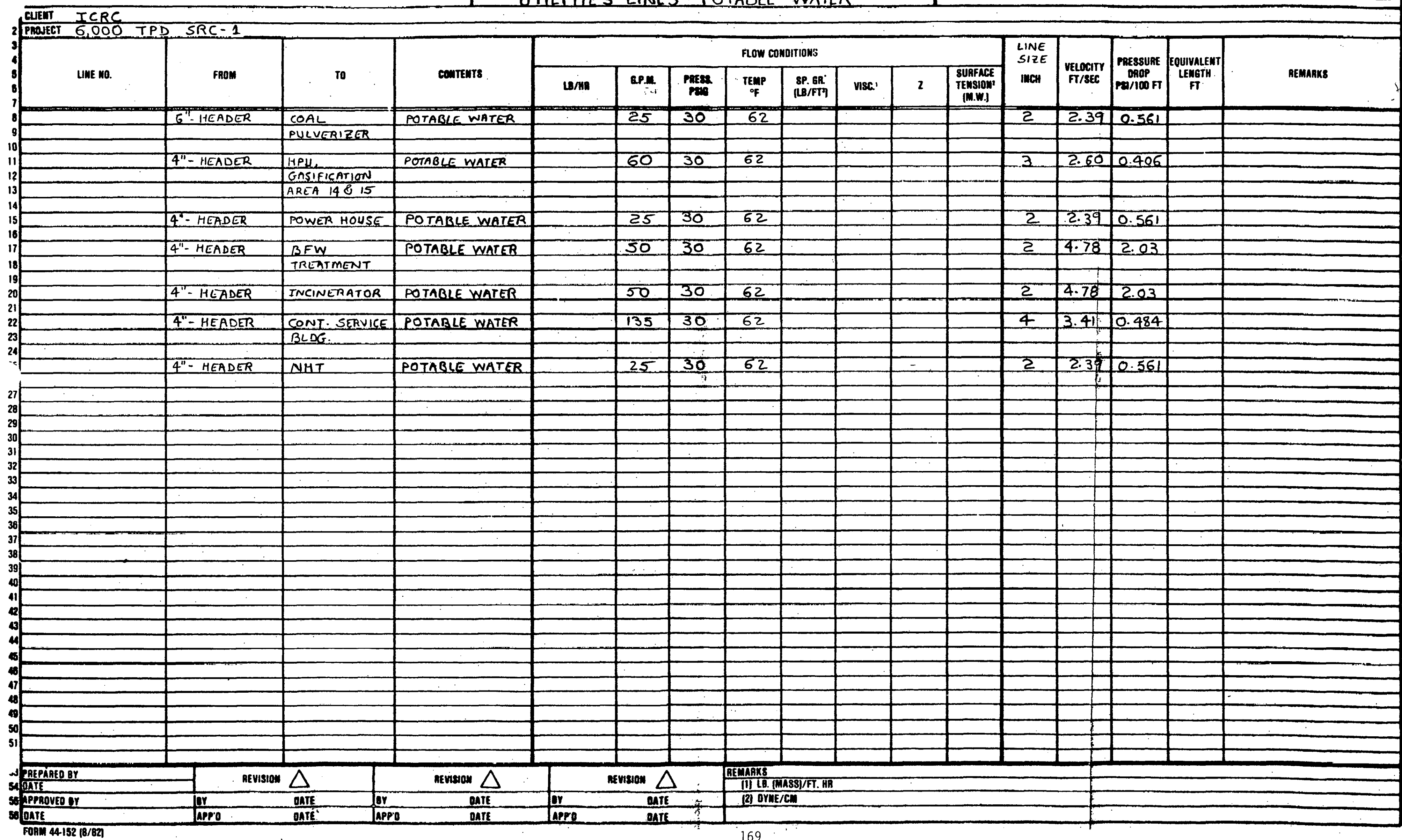




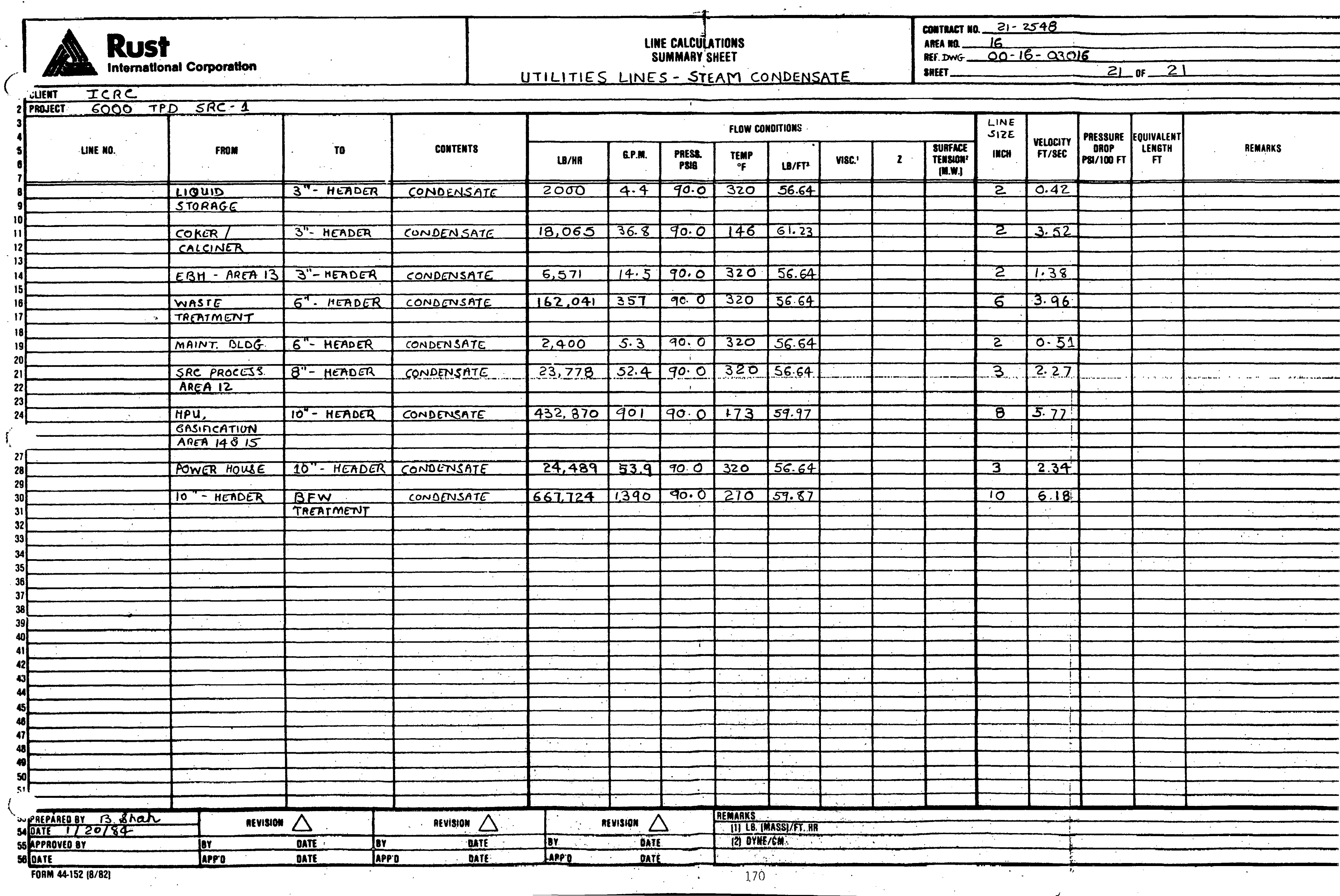




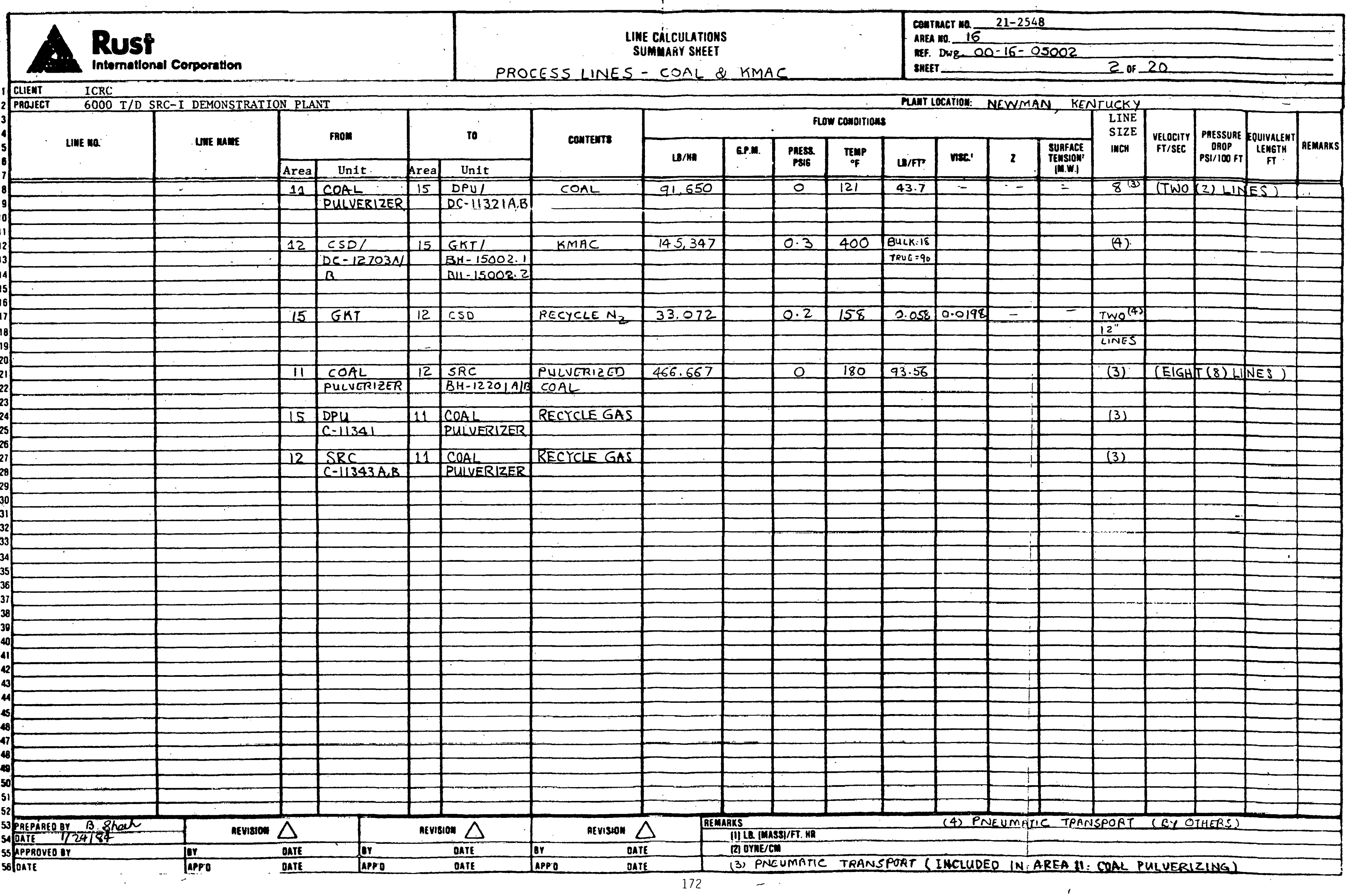




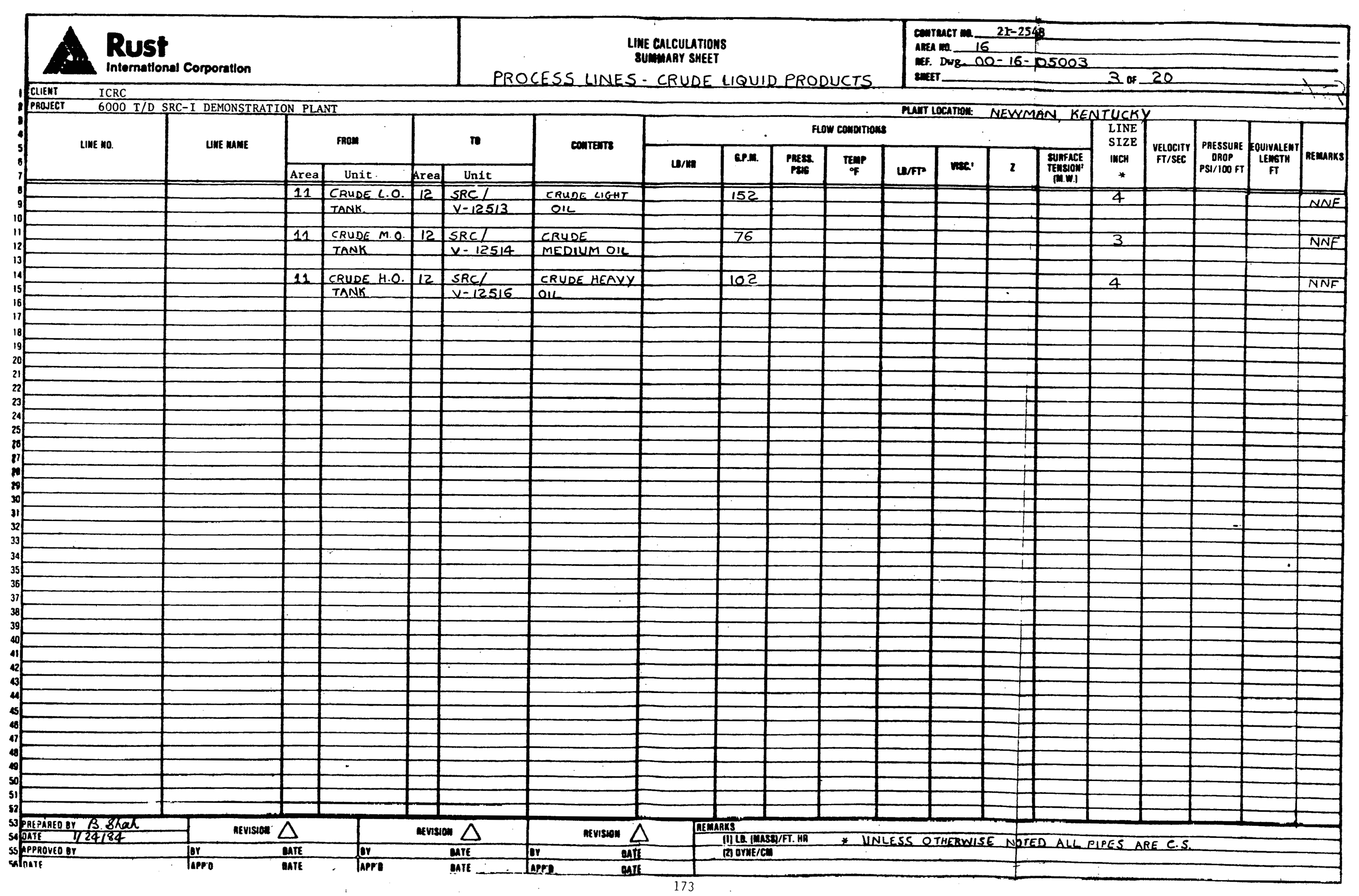




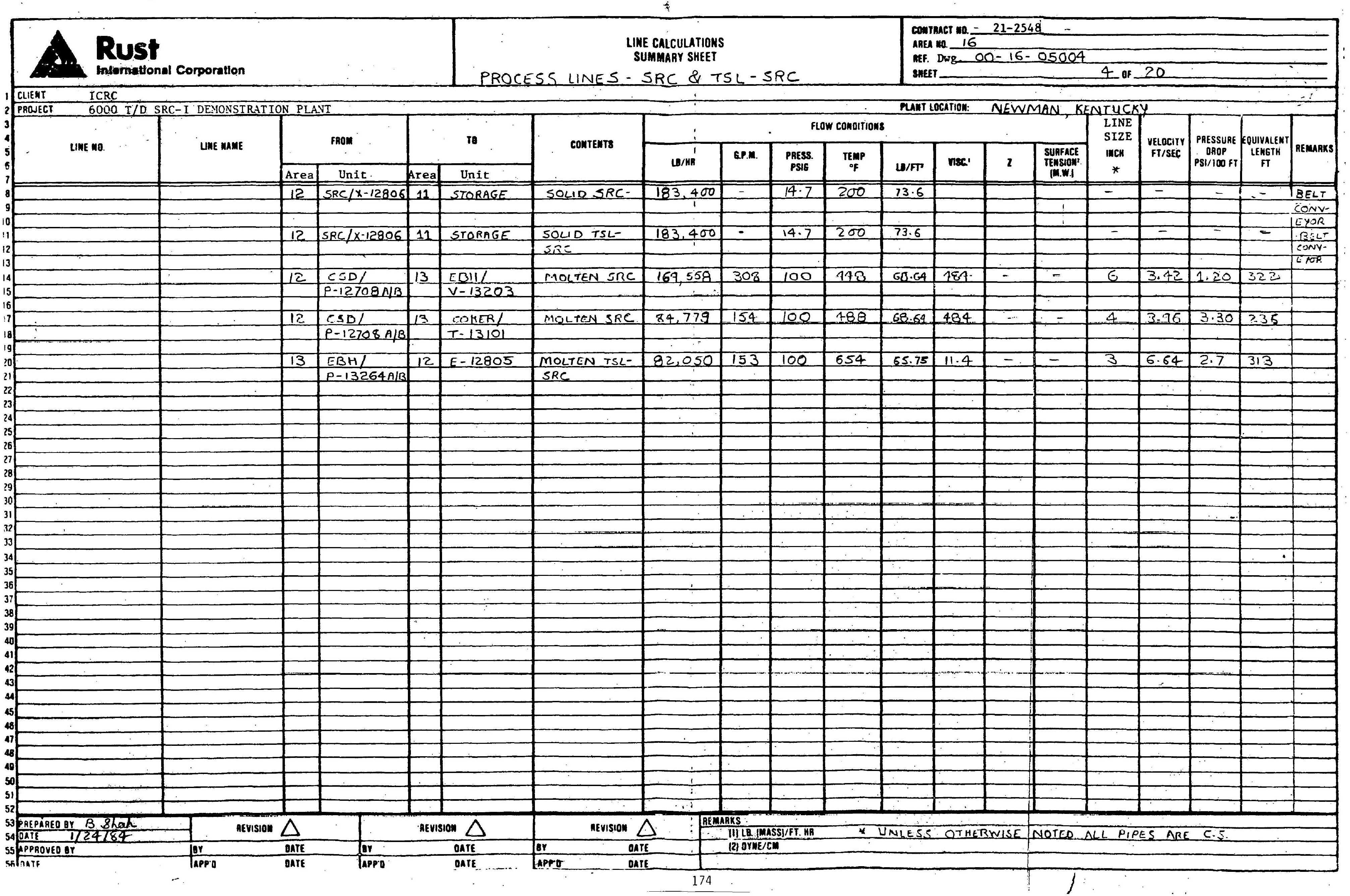




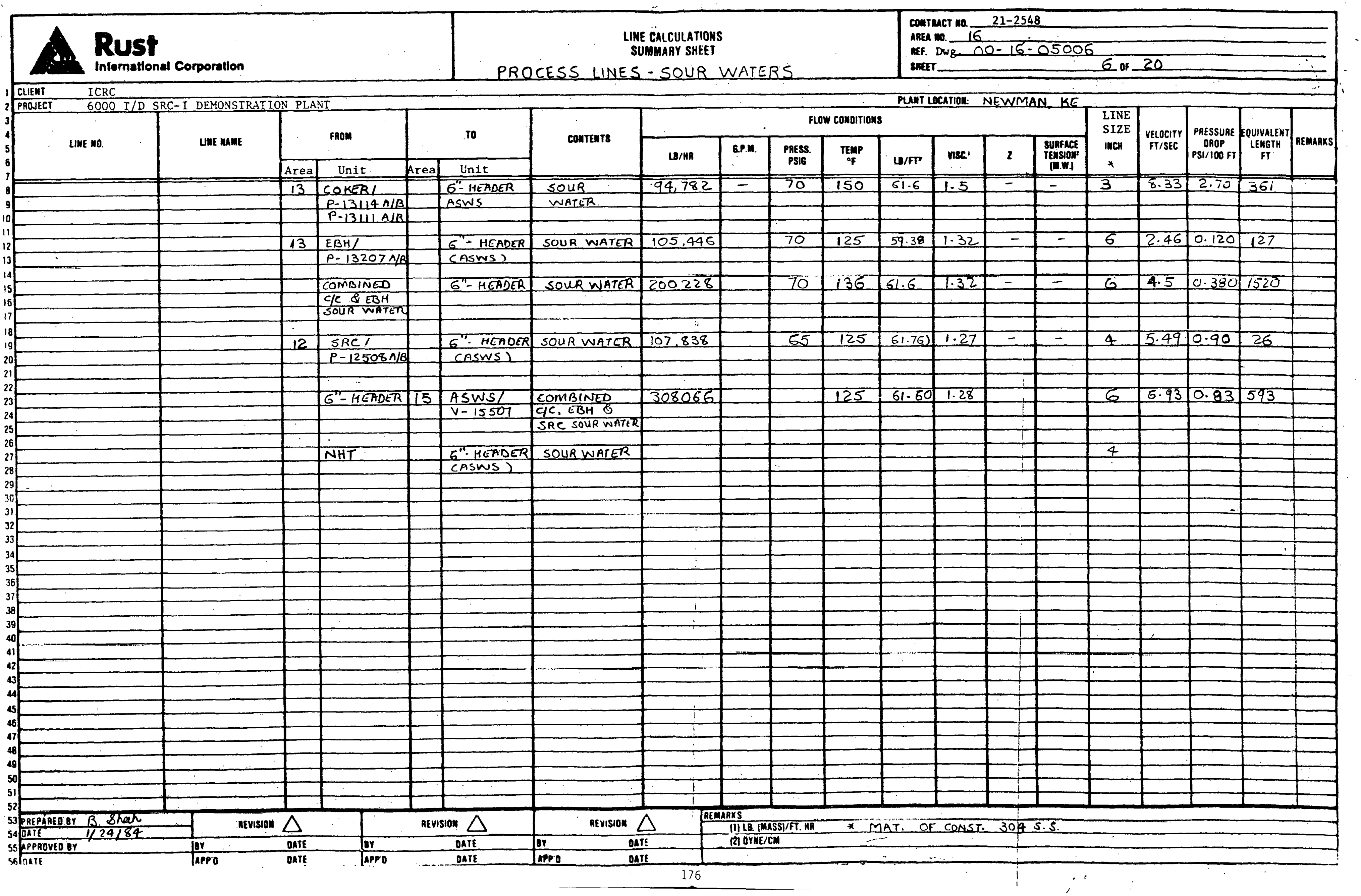




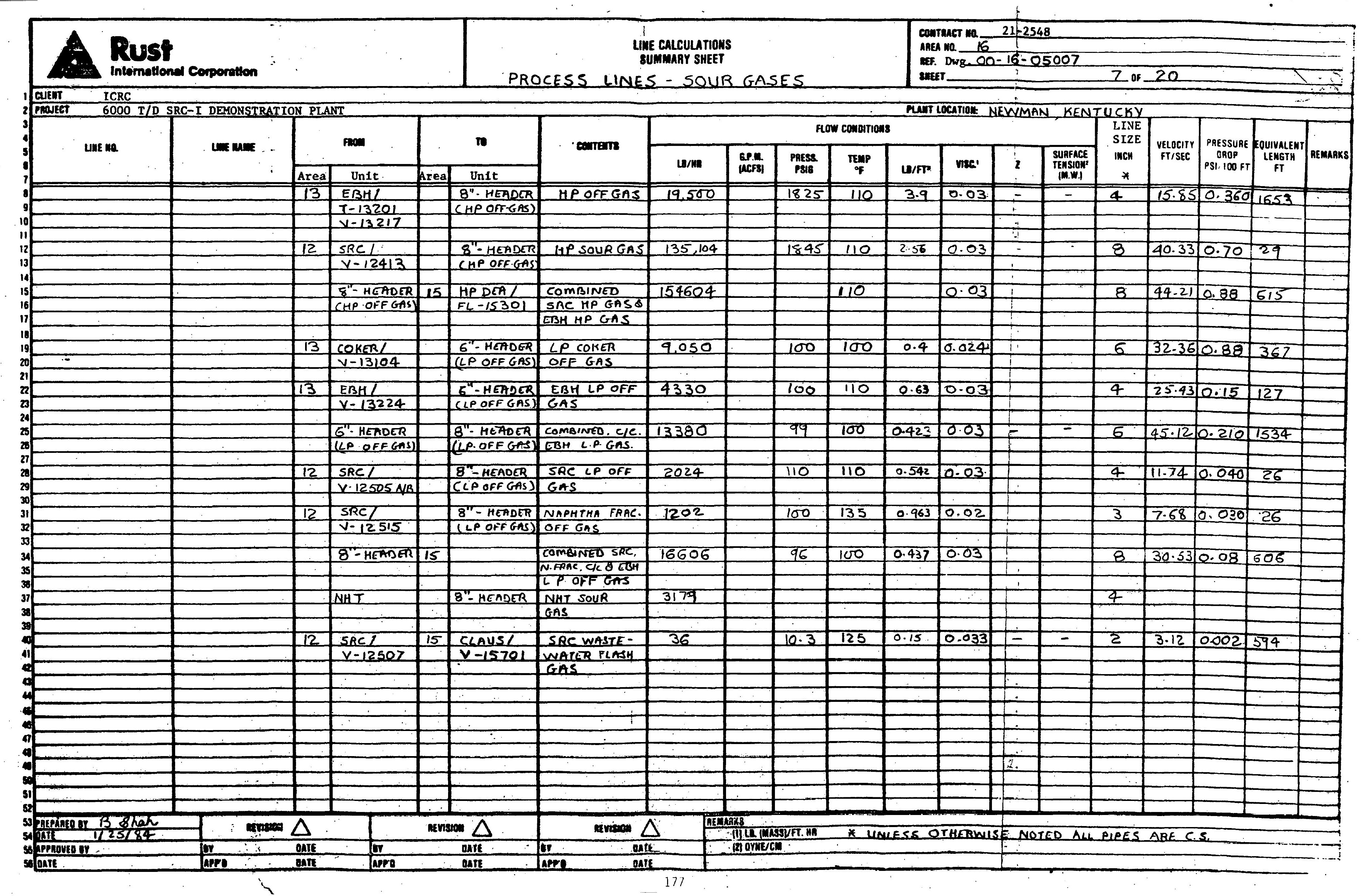




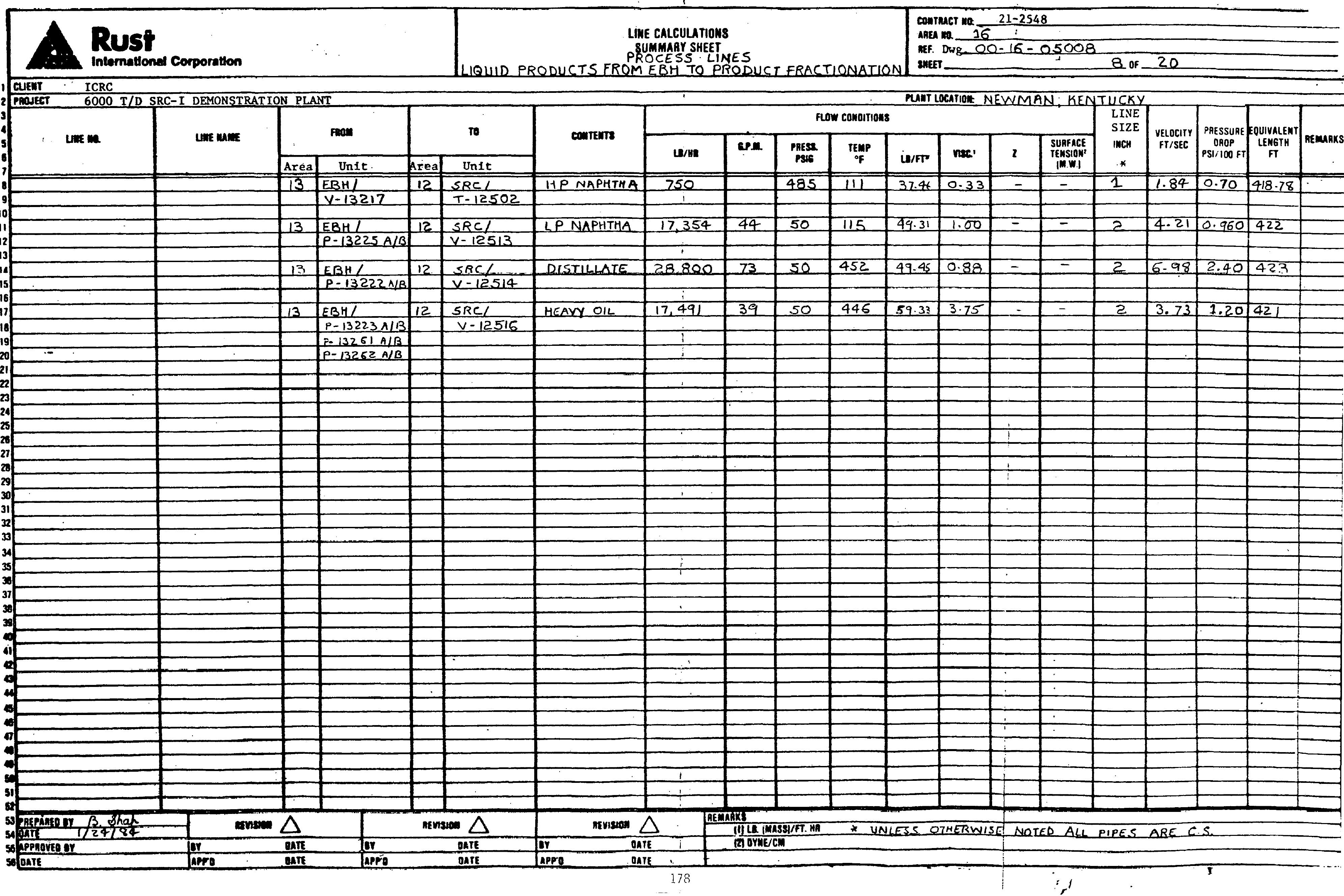




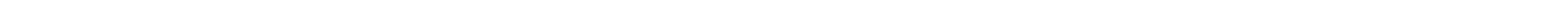




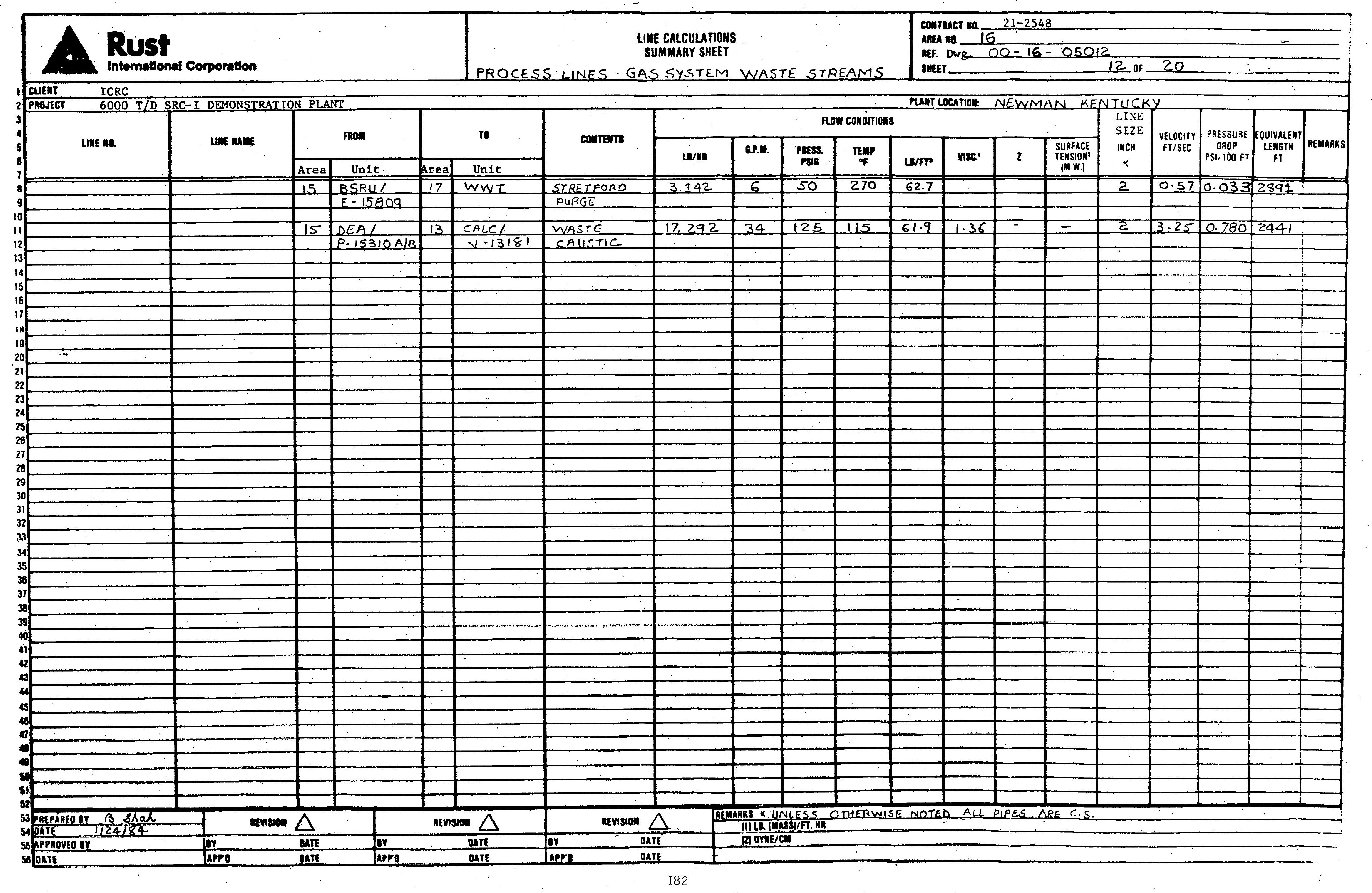




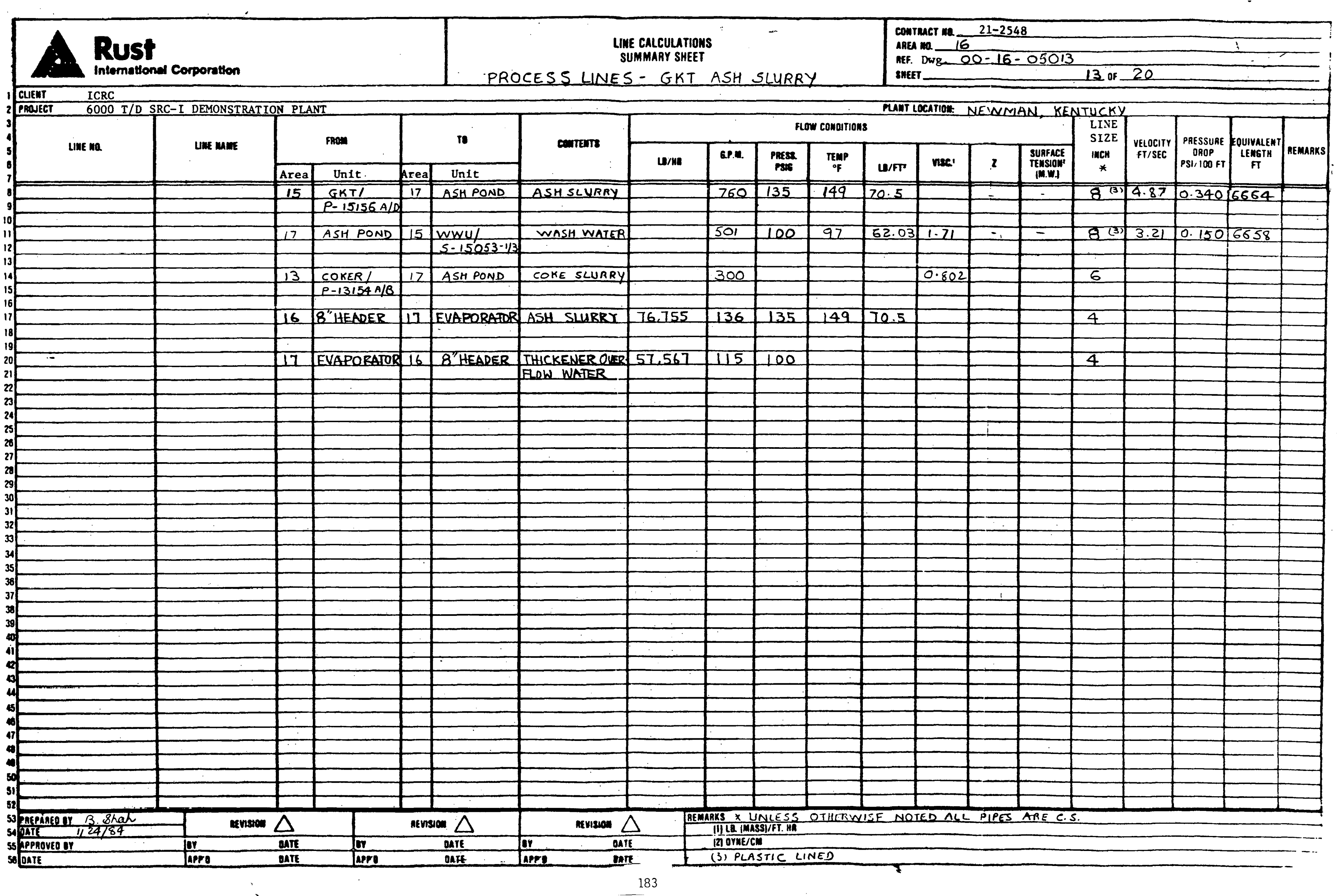




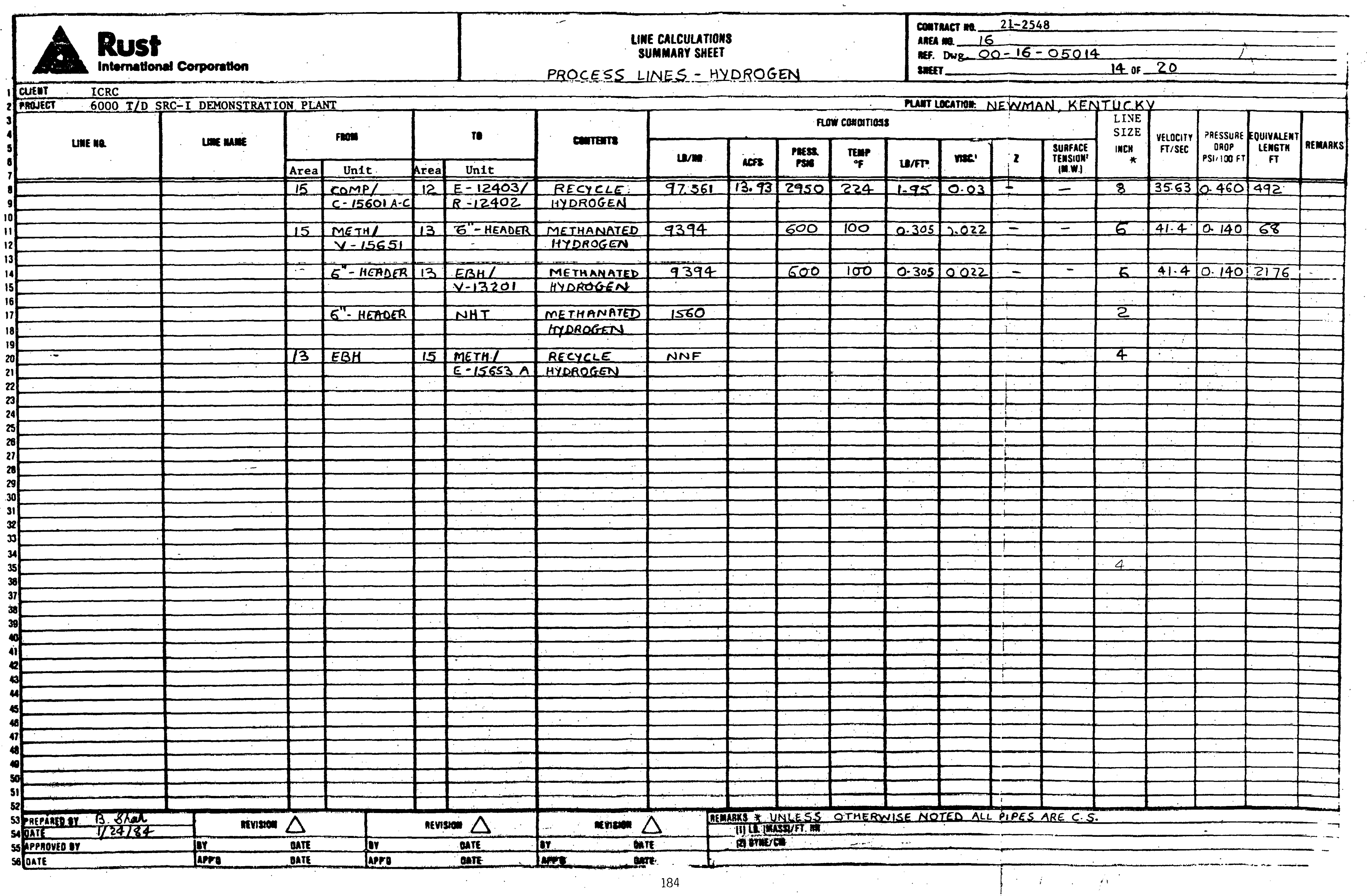




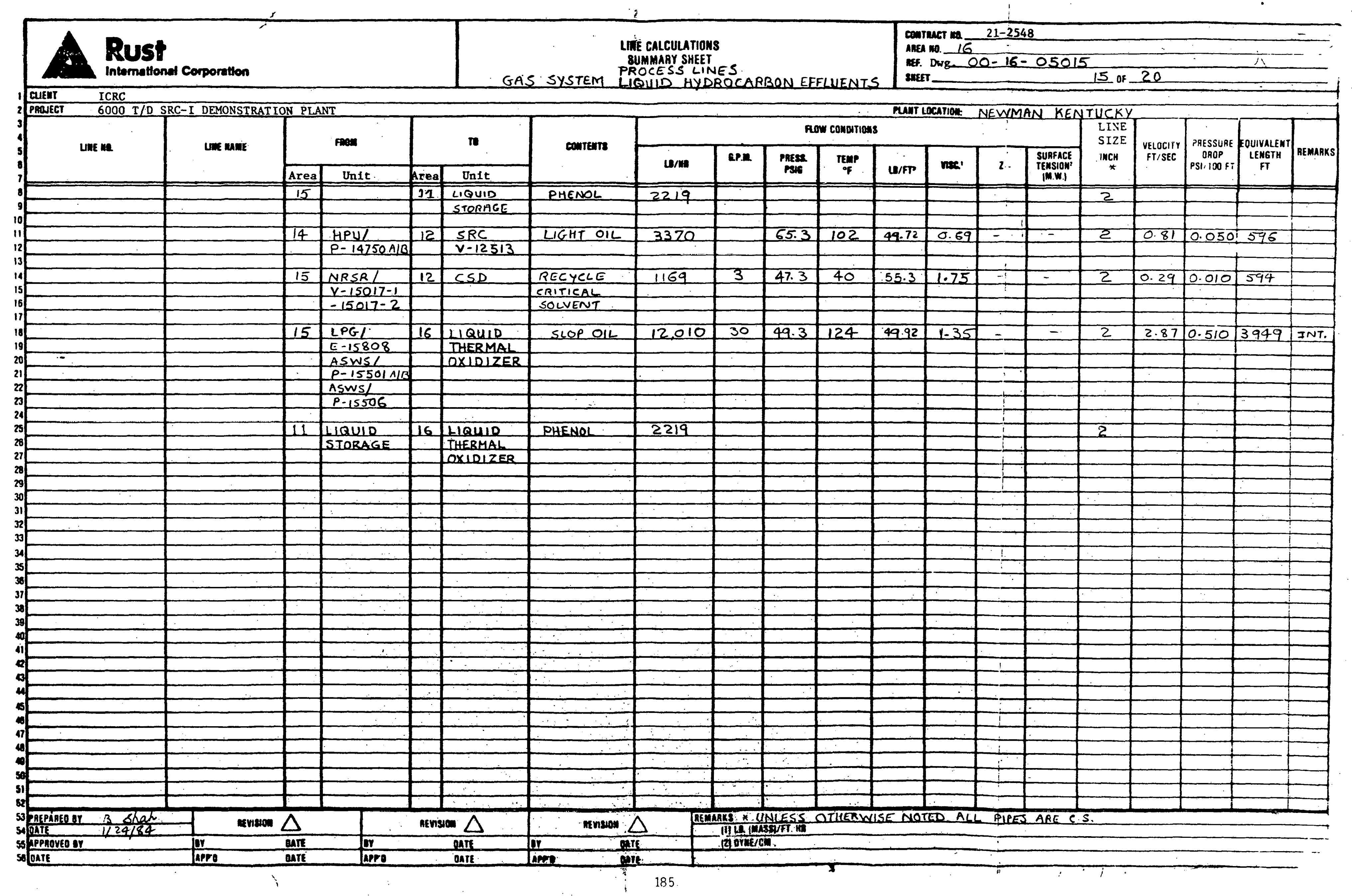




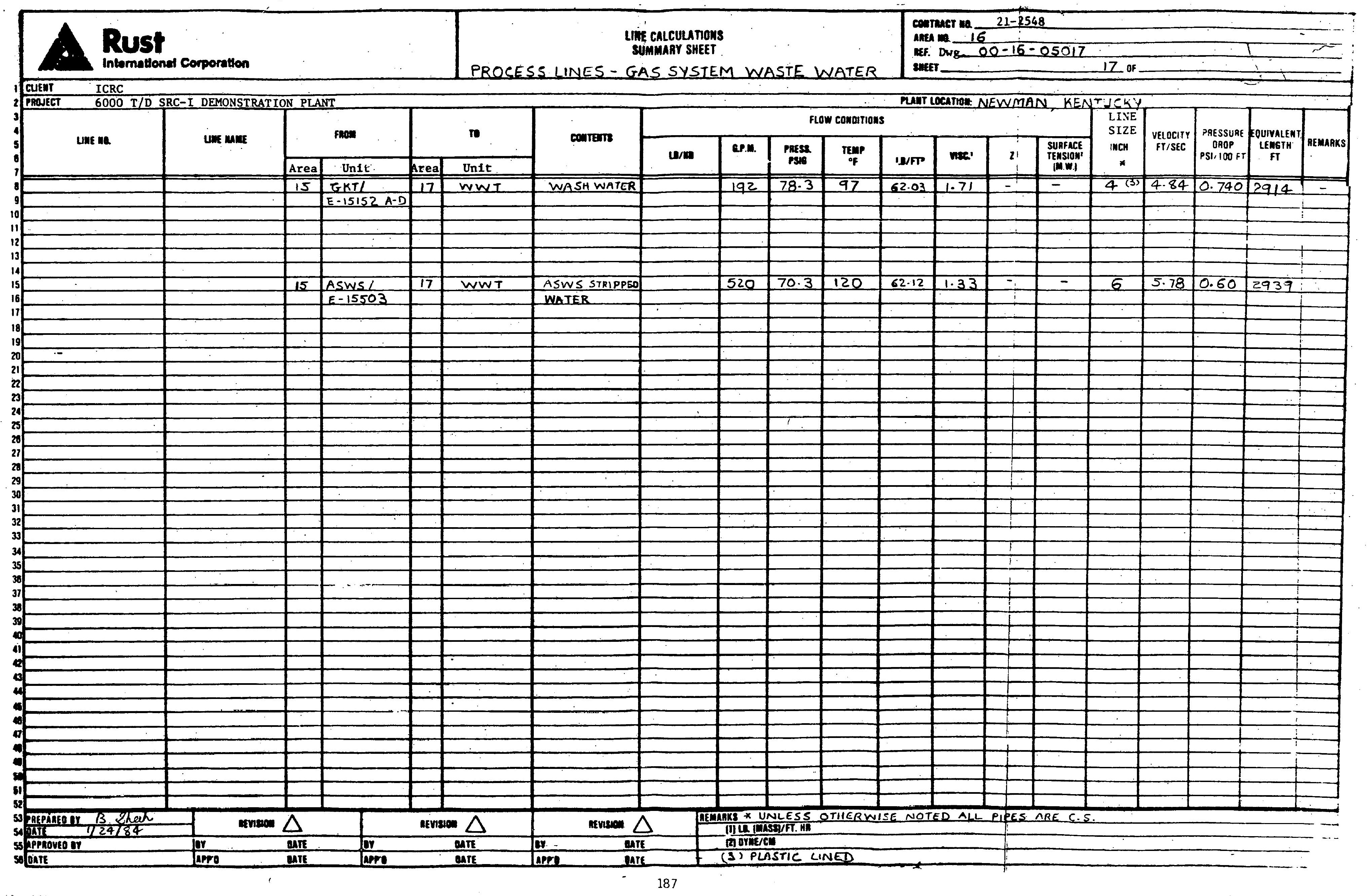




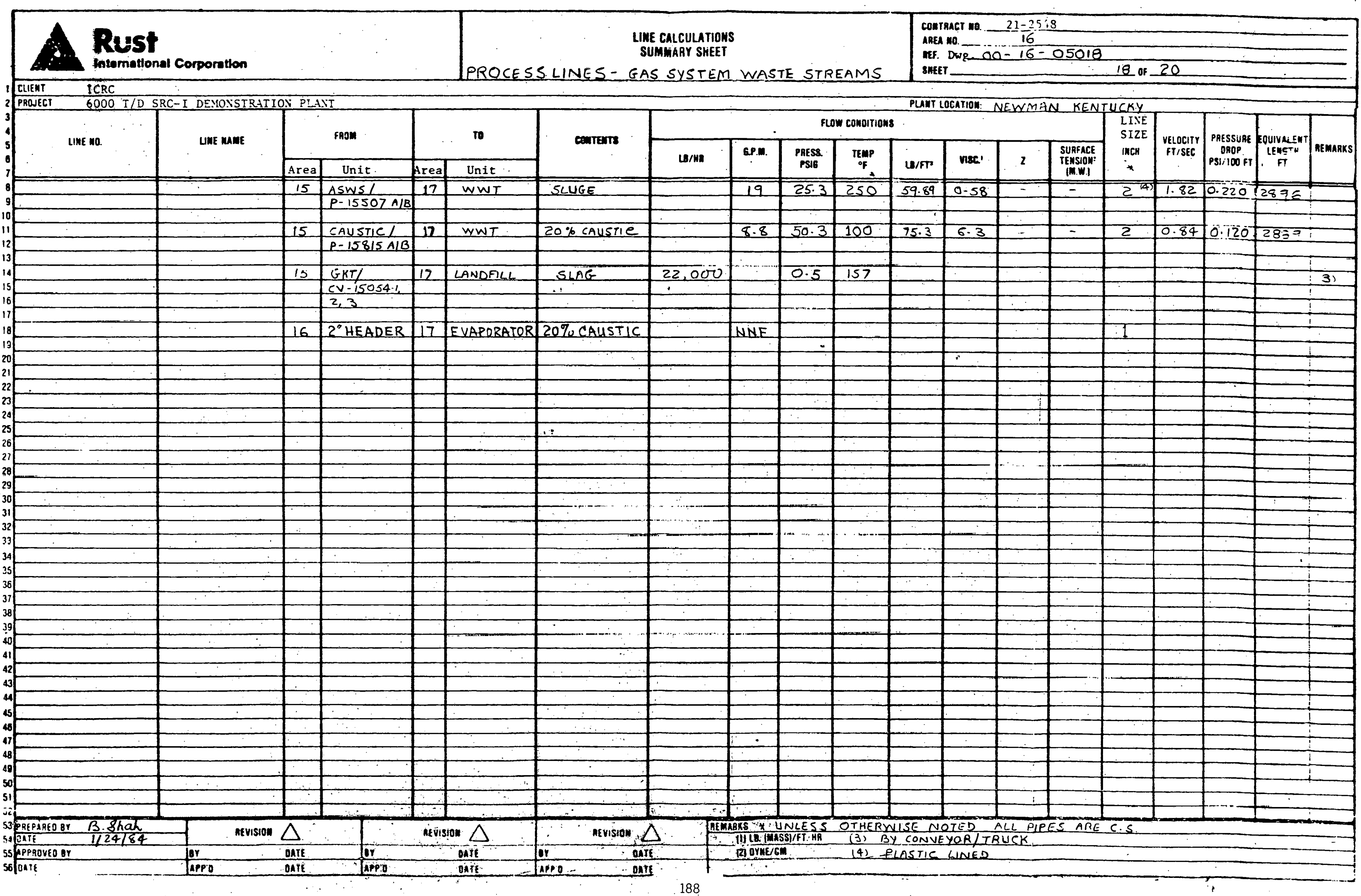




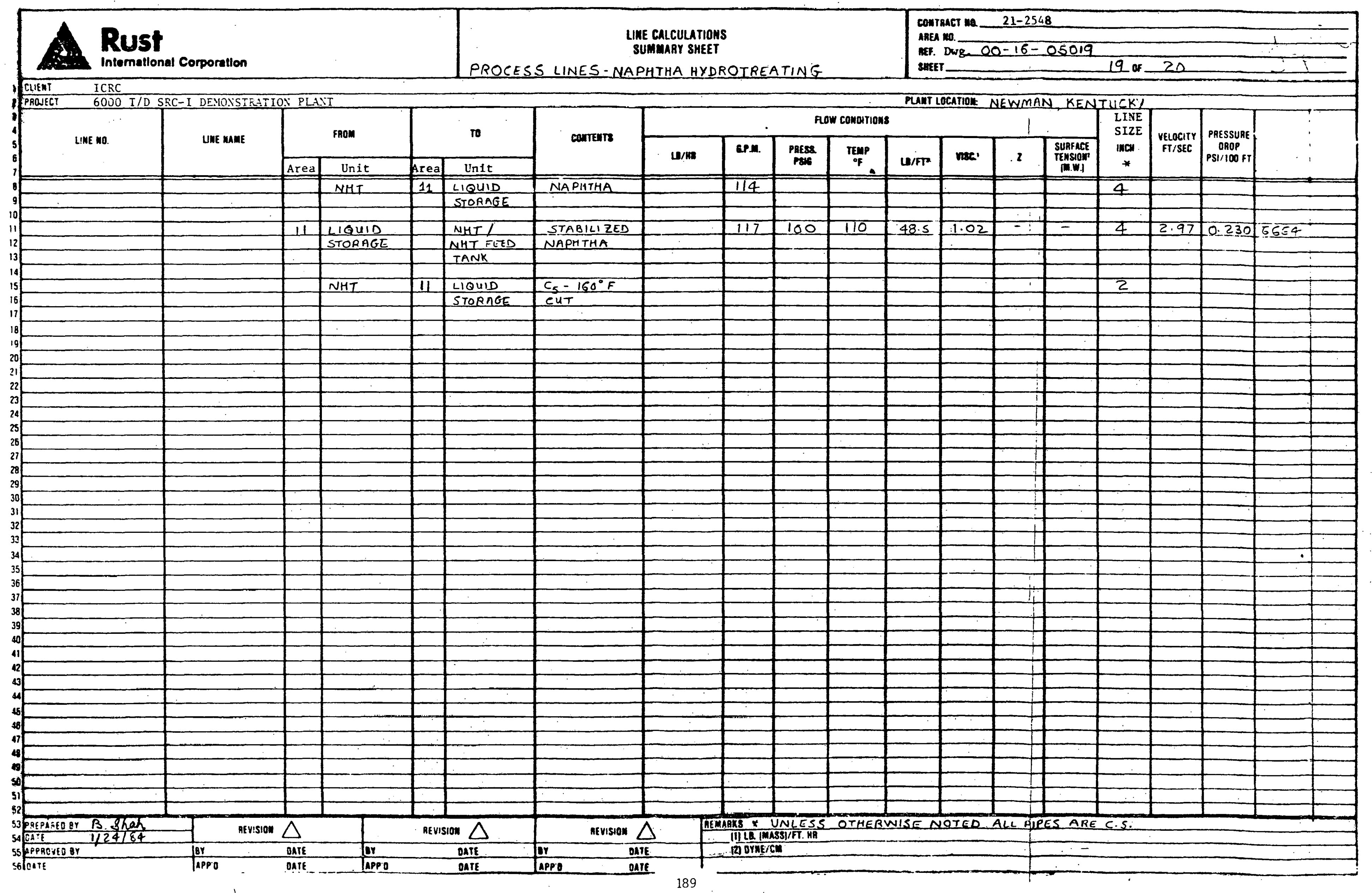




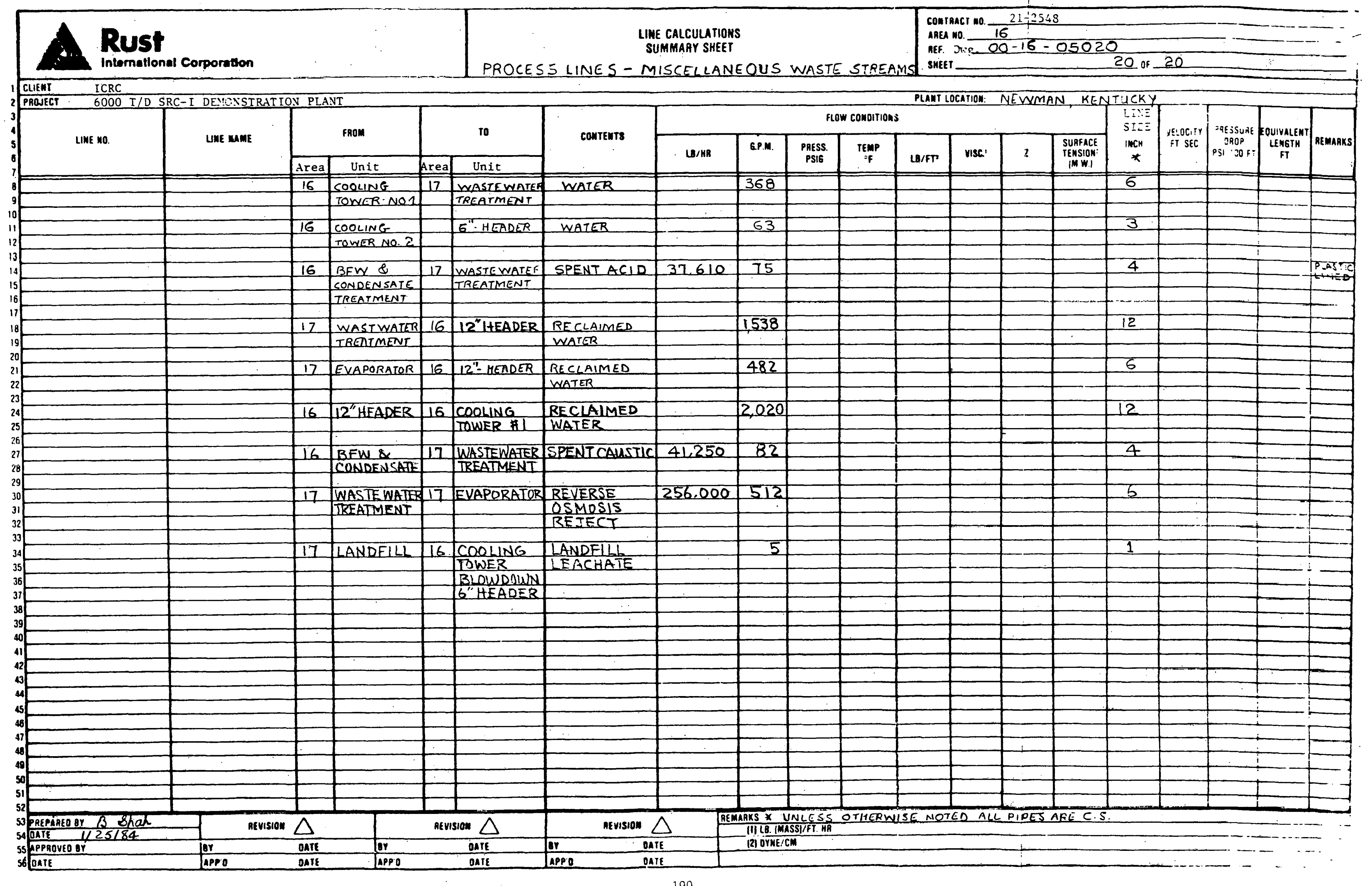




\subsubsection{Layout Drawings}

The following layout drawings are included after this page.

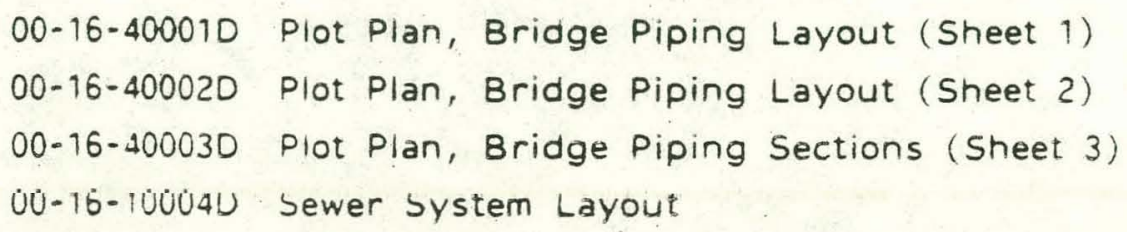




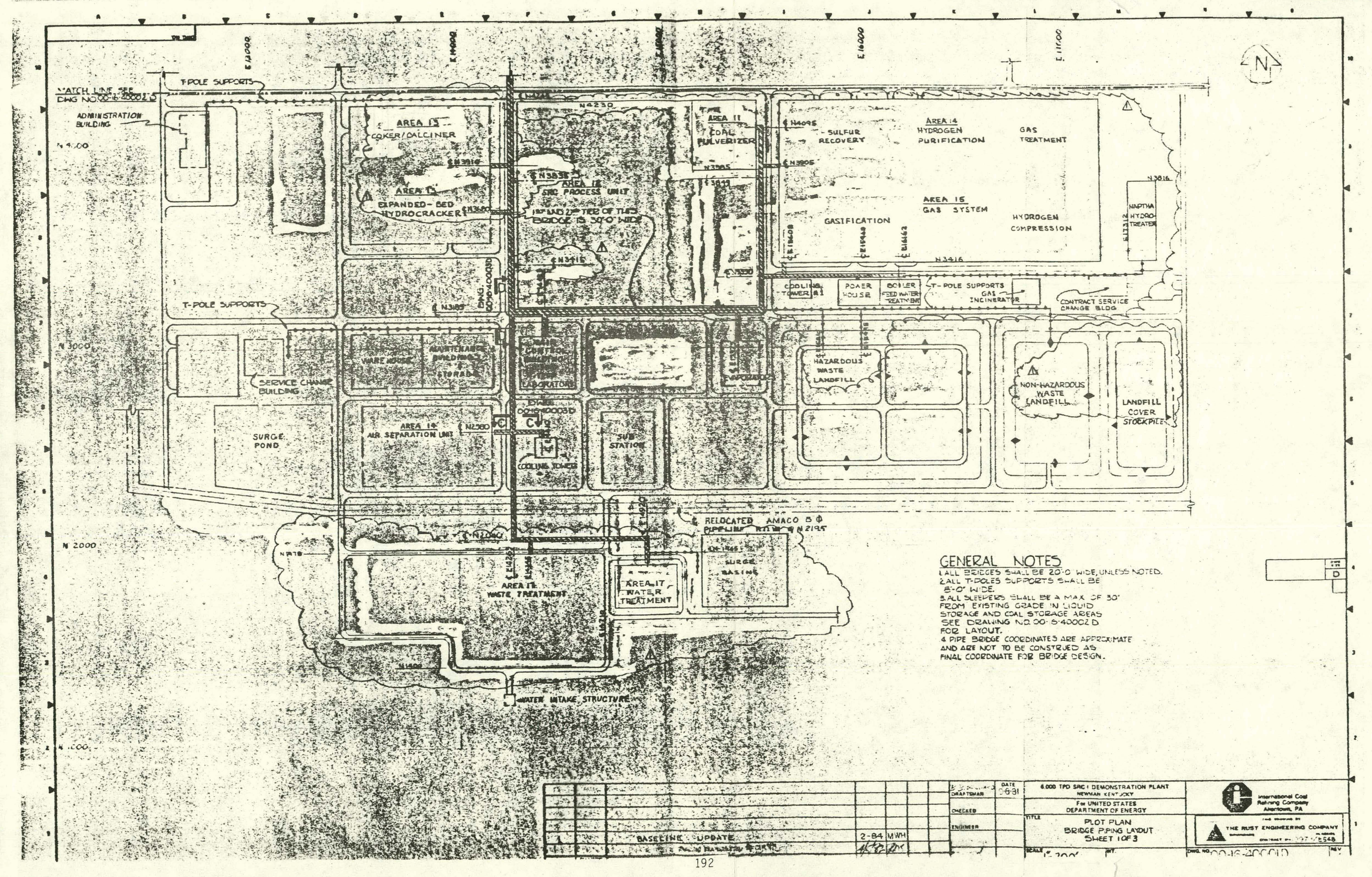




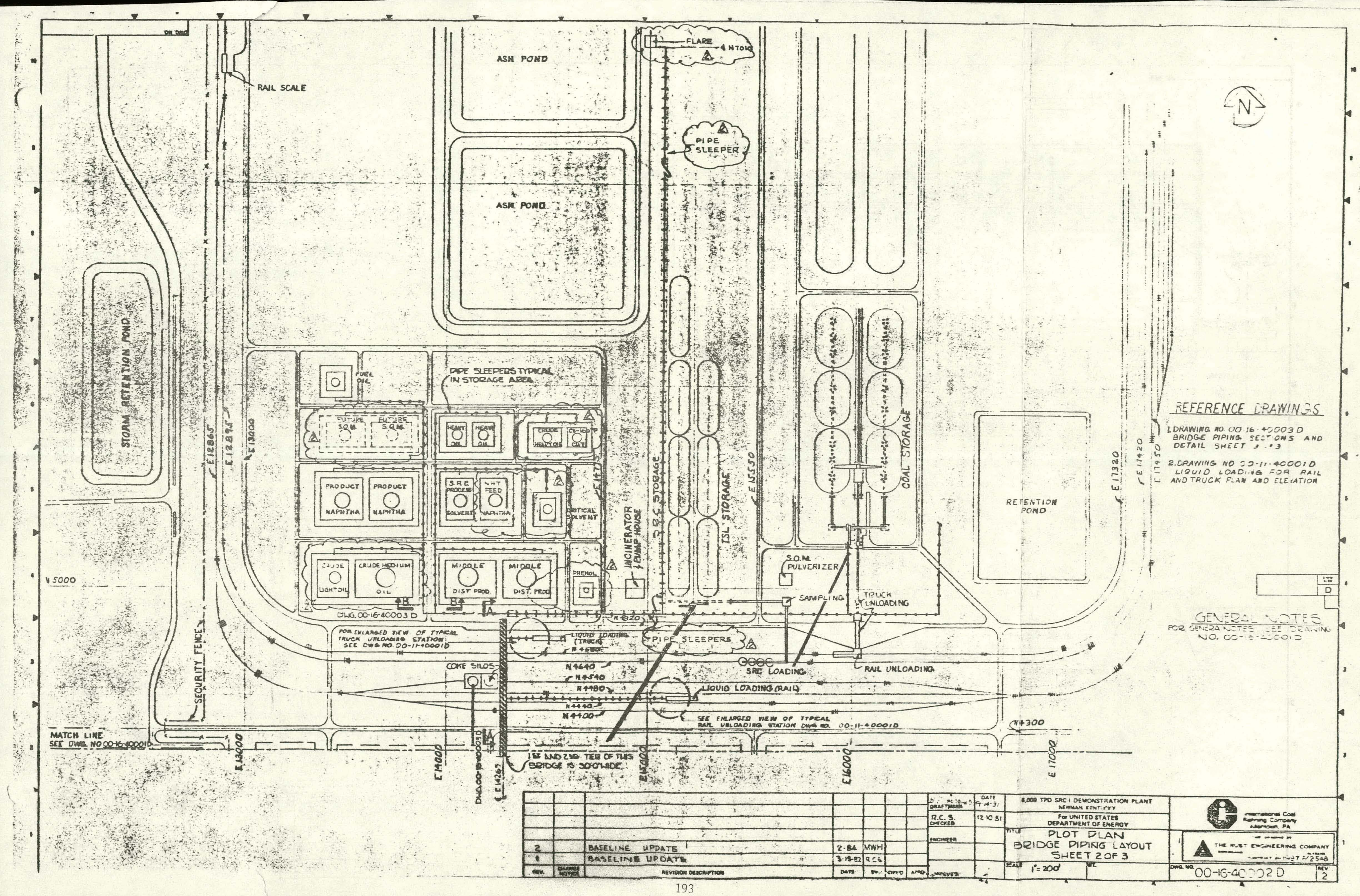




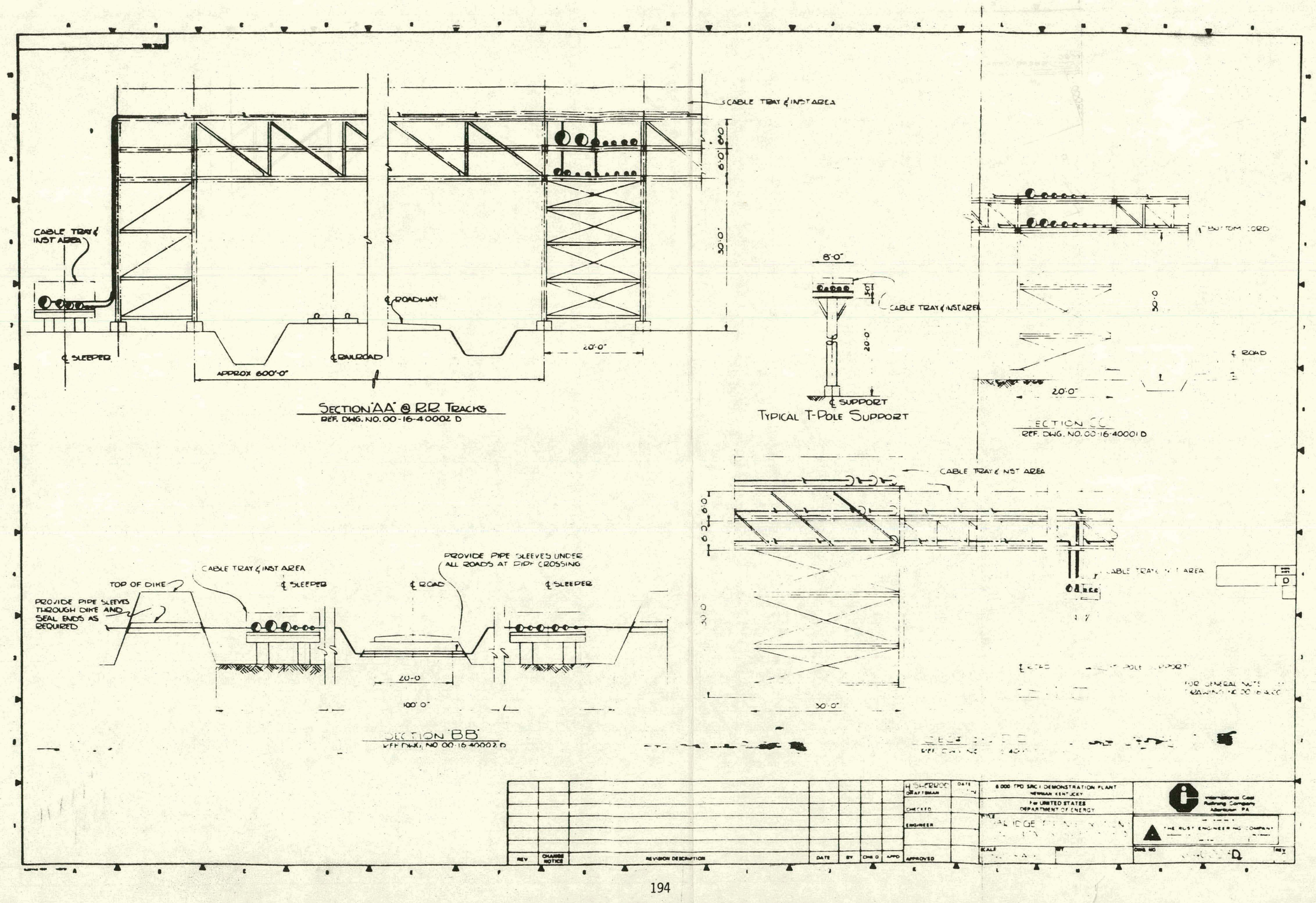




\subsection{UTILITY SYSTEMS INTEGRATION}

\subsubsection{Instrumentation Requiremenis}

2.4.1.1 The instrumentation and control system for the utilities and offsites of the SRC plant will be designed for extensive use of remote control systems which will be provided for all of the essential functions required for start-up, shutdown, selection of alternates, tlow routes, aperation of inter-related systems, removal of problem equipment from service, placing sparcs into opcration, and other operator activity that would otherwise require frequent trips to equipment items for local control.

2.4.1.2 The control system will utilize up-to-date state of the art techniques with special emphasis on operator interface. Micro-processor based control will be utilized with the analog loops arranged to permit relative ease of interface with the controllers. For most applications, the use of digital control will be supervisory set-point control.

2.4.1.3 Pneumatic instrumentation will be considered for application where environment prevents the use of electronic instruments. Otherwise pneumatic instrumentation will not be used, or will be limited to applicable areas.

2.4.1.4 Electronic loops for all areas will have 4-20 milliamp de signals, or as stated in the general engineering specification.

$\Rightarrow$ U.S. GOVERNMENT PRINTING OFFICE: $1985-544-063 / 10438$ 